\title{
ASPECTS OF PERMIAN PALAEOBOTANY AND PALYNOLOGY. IV. THE CONIFER ORTISEIA FLORIN FROM THE VAL GARDENA FORMATION OF THE DOLOMITES AND THE VICENTINIAN ALPS (ITALY) WITH SPECIAL REFERENCE TO A REVISED CONCEPT OF THE WALCHIACEAE (GOPPERT) SCHIMPER ${ }^{1}$
}

\section{JOHANNA A. CLEMENT-WESTERHOF \\ Laboratory of Palaeobotany and Palynology, State University, Heidelberglaan 2, 3584 CS Utrecht (The Netherlands)}

(Received September 19, 1983; revised version accepted December 7,1983 )

\section{ABSTRACT}

Clement-Westerhof, J.A., 1984. Aspects of Permian palaeobotany and palynology. IV. The conifer Ortiseia Florin from the Val Gardena Formation of the Dolomites and the Vicentinian Alps (Italy) with special reference to a revised concept of the Walchiaceae (Göppert) Schimper. Rev. Palaeobot. Palynol., 41: 51-166.

On the basis of rich material from the Val Gardena Formation in the Dolomites and the Vicentinian Alps, the Late Permian conifer Ortiseia Florin has been studied in detail with the aid of cuticle analysis. Originally described as a form-genus for sterile remains with preserved epidermal structure, the diagnosis of Ortiseia is considerably emended by including information on the organization of the ovuliferous and polliniferous cones. Pollen grains (prepollen) correspond to the palynological form-genus Nuskoisporites Potonié et Klaus. Within Ortiseia three distinctive species can be recognized: Ortiseia leonardii Florin, Ortiseia visscheri nov. sp. and Ortiseia jonkeri nov. sp.

The genus Ortiseia is compared in detail with the Late Carboniferous-Early Permian conifers Walchia Sternberg (synonym: Lebachia Florin) and Ernestiodendron Florin, especially with respect to the organization of the ovuliferous cone. There is every indication that the three genera are characterized by inverted ovules, which are abaxially attached on megasporophylls. Such a characteristic is in conflict with generally accepted reconstructions of Walchia and Ernestiodendron. Consequently, the diagnoses of these genera are emended; together with Ortiseia they are classified within the family Walchiaceae (Göppert) Schimper. Two species, formerly included in Lebachia have been transferred to Walchia: W. garnettensis (Florin) nov. comb. and W. goeppertiana (Florin) nov. comb.

The form-genus Culmitzschia Ullrich is emended to include sterile walchiaceous remains with preserved epidermal structure. A number of species formerly included in Lebachia have been transferred to Culmitzschia: $C$. angustifolia (Florin) nov. comb., C. frondosa (Renault) nov. comb., C. hirmeri (Florin) nov. comb., C. intermedia (Florin) nov. comb., C. laxifolia (Florin) nov. comb., C. mitis (Florin) nov. comb., C. mucronata (Florin) nov. comb. and C. speciosa (Florin) nov. comb.

\footnotetext{
${ }^{1}$ Contribution to the UNESCO/IUGS International Geological Correlation Programme (IGCP) Project No. 106: "Permo-Triassic Stage of Geological Evolution".
} 
From a phylogenetic point of view, the position of the Walchiaceae is less pronounced than is generally stated. The Cordaitales cannot be regarded as the direct ancestors of the family, whereas unambiguous descendants remain unknown.

\section{RIASSUNTO}

In base al ricco materiale proveniente dalla Formazione di Val Gardena nelle Dolomiti ed Alpi Vicentine, la conifera Ortiseia Florin del Permiano superiore è stata studiata in detaglio con l'aiuto dell'analisi di cuticola. Originalmente descritta come form-genus di resti sterili di cui è conservata la struttura epidermale, la diagnosi di Ortiseia è emendata in base alla organizzazione dei coni ovuliferi e pollinici. I grani di polline (prepolline) corrispondo alla form-genus palinologica Nuskoisporites Potonié et Klaus. In Ortiseia si possono distinguere tre specie distinte: Ortiseia leonardii Florin, Ortiseia visscheri nov. sp. ed Ortiseia jonkeri nov. sp.

Il genere Ortiseia è confrontato in detaglio con le conifere Walchia Sternberg (sinonimo: Lebachia Florin) ed Ernestiodendron Florin del Carbonifero superiorePermiano inferiore, specialmente in riferimento all'organizzazione dei coni ovuliferi. Appare evidente che $\mathrm{i}$ tre generi sono caratterizzati da ovuli inversi distribuiti abassialmente su foglie fertili. Una tale caratteristica è in contrasto con la riconstruzione generalmente accettata di Walchia ed Ermestiodendron. Consequentemente questi generi sono stati emendati; insieme ad Ortiseia sono classificati nella famiglia Walchiaceae (Göppert) Schimper. Due specie, inizalmente incluse in Lebachia, sono ora attribuite a Walchia: W. garnettensis (Florin) nov. comb. e W. goeppertiana (Florin) nov. comb.

La form-genus Culmitzschia Ullrich è emendata in modo da includere resti sterili di Walchiaceae con struttura epidermale riconoscibile. Un numero di specie, dapprima incluse in Lebachia, sono ora attribuite a Culmitzschia: C. angustifolia (Florin) nov. comb., C. frondosa (Renault) nov. comb., C. hirmeri (Florin) nov. comb., C. intermedia (Florin) nov. comb., C. laxifolia (Florin) nov. comb., C. mitis (Florin) nov. comb., C. mucronata (Florin) nov. comb. e C. speciosa (Florin) nov. comb.

Da un punto di vista filogenetico, la posizione delle Walchiaceae è meno pronunciata di quanto generalmente accettato. Le Cordaitales non possono essere considerate come le dirette antenate della famiglia, mentro rimangono sconosciuti evidenti discendenti.

\section{INTRODUCTION}

In outer Alpine parts of Western Europe two types of Permian floras have traditionally been distinguished: (1) Early Permian (Autunian or "Lower Rotliegendes") floras, characterized by the pteridosperm Callipteris, in combination with coniferous remains classified as Walchia; subsequently, following Florin (1938-1945), the latter remains usually became included in the genera Lebachia and Ernestiodendron. (2) Late Permian (Thuringian or "Zechstein") floras, characterized by coniferous genera, such as Ullmannia and Pseudovoltzia. These two types of floras are completely different from each other; they do not share a single common element. In fact they have been the base for the classic palaeobotanical demarcation of the "Palaeophytic" and "Mesophytic".

Records of transitional floras, which might characterize the classic West European Middle Permian (Saxonian or "Upper Rotliegendes") are extremely rare. Reported joint occurrences of Walchia and Ullmannia are insufficiently documented.

While elsewhere in Europe the Permian floras were generally attributed to 
either the Lower or the Upper Permian, the stratigraphical position of the Permian floras from the Southern Alps remained obscure.

Already in the second part of the nineteenth century, fossil floras from the Southern Alps were mentioned by, e.g., De Zigno (1862), Massalongo (1863), Gümbel (1879) and Bittner (1879, 1881). Also the flora from Hungary, described by Heer (1876) may be regarded as an Alpine Permian flora. However, both from a taxonomic and stratigraphical point of view, these floras were inadequately treated. Also the more recent investigations (Charrier, 1964; Florin, 1964; Leonardi, 1951; Jung, 1977; Remy and Remy, 1978) provide a very incomplete and often conflicting picture of both the composition and age of Alpine Permian floras.

Early authors considered the floras from the Vicentinian Alps to be Triassic (De Zigno, 1862; Massalongo, 1863), but later investigations (e.g., Von Mojsisovics, 1876; Bittner, 1883; Tornquist, 1901) proved their Permian affinity. In later years, especially the Permian floras from the Val Gardena Formation (German: Grödener Schichten) of the Dolomites became a source of controversy with respect to their stratigraphical interpretation. According to most authors (e.g., Leonardi, 1967; Remy and Remy, 1978) they should (at least partly) represent a Middle Permian (Saxonian or Upper Rotliegendes) age. Such an assumption was based on the presumed mixed character of the floras, which, according to published floral lists, seemed to contain both Early Permian and Late Permian elements (Walchia and Ullmannia, respectively).

Also the palynofloras, well described by Klaus (1963), have been partly interpreted in terms of Middle Permian, despite their resemblance to Late Permian assemblages from outer Alpine Europe.

Actuated by the controversies concerning the status of the Saxonian Stage in chronostratigraphical classification (Visscher, 1971; Visscher et al., 1974 ), in the early seventies a palaeobotanical/palynological research project was started in the Permian of the Southern Alps by staff members and students of the Laboratory of Palaeobotany and Palynology of the State University of Utrecht. This project is aimed at an interregional evaluation of the Permian in the Southern Alps through a detailed study of megafloras and palynofloras; it has been integrated in the activities of the UNESCO/ IUGS International Geological Correlation Programme (IGCP) Project No. 106: "Permo-Triassic Stage of Geological Evolution".

Since 1971 the present author has been engaged in the palaeobotanical aspects of the project, in combination with the study of in situ pollen grains. The objectives of this research are the following:

(1) A detailed insight in the composition of the floras of the Val Gardena Formation of the Dolomites and the Vicentinian Alps.

(2) A new insight in the morphology, taxonomy and phylogeny of selected categories of Permian plants, by correlating sterile and fertile remains in order to reconstruct, as far as possible, natural plant taxa rather than recognizing imperfect (form) taxa.

(3) A study of spores and pollen grains in situ in order to correlate palynofloras and megafloras. 
(4) A stratigraphical, phytogeographical and palaeoecological evaluation of palaeobotanical information.

Results are being published in the series "Aspects of Permian palaeobotany and palynology" of the Laboratory of Palaeobotany and Palynology, Utrecht. Before providing a definitive palaeobotanical synthesis, the plant taxa, found in the Val Gardena Formation will be treated in detail in separate papers.

As the first taxon to be treated, the coniferous genus Ortiseia Florin 1964 has been selected. The main reason for this choice is the fact that this conifer is not mentioned from the Permian of outer Alpine regions. Moreover, its resemblance to other Palaeozoic conifers such as Lebachia, Ernestiodendron and Walchia, well-known through the extensive treatment by Florin (1938-1945), was considered to be of potentional importance for phylogenetic considerations. The present paper, therefore, has the following objectives:

(1) A detailed morphological-taxonomic study of the genus Ortiseia, including descriptions of its ovuliferous and polliniferous organs.

(2) A comparison of Ortiseia with other Palaeozoic conifers, with emphasis on a revision of the controversial status of the genus Walchia Sternberg.

(3) A discussion on the implications of the organization of Ortiseia in conifer phylogeny.

\section{DEDICATION}

This paper is dedicated to the memory of Prof. Dr. T.M. Harris, who has inspired so many students of palaeobotany. His clear and engaging analysis of how palaeobotanists interpret the varied morphological features in fossil conifers has continuously guided my investigations:

"This is comparative morphology. Views on this range widely, my own are unformed but since I use it here I must take some position. So I regard it as a game of skill played with Nature. It is a game where the player is constrained by rigid rules and he plays it with knowledge and with imagination. It is like the card game patience where you take a random pack, deal the cards out and then try to arrange them in order, but strictly according to rule. You have some freedom of choice and if you choose wrongly the game will fail to come out, and of course you must never cheat."

[Harris, 1976, p.128]

\section{THE VAL GARDENA FORMATION}

The lithostratigraphical and palaeogeographical position of the Val Gardena Formation (German: Grödener Schichten) has been variously interpreted by the many geologists who tried to establish a regional picture of the Permian of the Southern Alps. In the extensive literature also many controversial views with regard to the age of the formation have been expressed. 
Since the present paper is part of a series of contributions which may ultimately lead to a better understanding of the Val Gardena Formation, it would be premature to provide a comprehensive account on the stratigraphical unit. It is sufficient to give a general background of the formation, reflecting the stratigraphical and depositional model, accepted as a working hypothesis within our Permian research project (Van de Laar, 1980; H. Visscher, unpubl. notes). This model is mainly based on the stratigraphical and palaeostructural studies, carried out during the last two decades (compare, e.g., Assereto et al., 1973; Buggish, 1978) in combination with the preliminary results of palynostratigraphical investigations (Van de Laar, 1980).

\section{Lithological considerations}

The Val Gardena Formation is recognized throughout the eastern part of the Southern Alps (Dolomites-Slovenia). The formation consists of wellbedded sandstones of variable grains, often micaceous, grading into fine siltstones and argillites or, locally, into conglomerates. The colour is generally red or reddish; grey or green intercalations may, however, be frequently observed. Also lenses or beds of gypsum frequently occur. Locally rare calcareous interbeds are present.

In the Dolomites the thickness of the Val Gardena Formation is variable; it averages $150 \mathrm{~m}$ (see Leonardi, 1967). In this area, the succession overlies the thick Permian volcanic sequence, known as the "Bolzano Porphyry Complex". In the Vicentinian Alps, the formation is greatly reduced in thickness and varies between 20 and $50 \mathrm{~m}$ (see Barbieri et al., 1980). Here Permian volcanics are absent, so that the succession rests uncomformably on the metamorphic pre-Permian basement.

In the Dolomites and the Vicentinian Alps cross-bedded sandy and silty lithologies dominate. The sequence represents an alluvial-plain facies (Bosellini and Dal Cin, 1968). Towards the top of the formation, however, one may recognize a silt-dominant floodplain facies, which increases in importance eastwards and becomes dominant near the Italian-Yugoslavian border. In a westward direction, on the other hand, the Val Gardena Formation grades laterally into a more conglomeratic succession, known as the "Verrucano Lombardo", and representing piedmont deposition.

East of the Adige Valley, the Val Gardena Formation is overlain and, partly, replaced by the marine deposits of the Bellerophon Formation. The change to marine conditions is gradual, as is demonstrated by the transitional boundary between the two formations, showing an interfingering of red beds and carbonates. The Bellerophon Formation may be roughly divided into two facies: (1) a dolomite-gypsum facies, representing a lagoonsabkha complex, laterally replaced and overlain eastwards by (2) a micriticskeletal carbonate facies, representing a neritic depositional environment.

Evaluating the regional trends in facies development, it may be concluded that the different facies (Verrucano Lombardo, Val Gardena Formation, 
Bellerophon Formation) represent the results of partly contemporaneous sedimentations in diverse environments, following each other, along a palaeoslope, inclined gently towards the east (compare Assereto et al., 1973, fig.3). Throughout the Southern Alps the different facies are disconformably overlain by the shallow-marine deposits of the Werfen Formation (Lower Triassic).

Age

The regional depositional relations strongly indicate a diachronous nature of the base of the Val Gardena Formation, as well as of the transition Val Gardena Formation-Bellerophon Formation. Such a picture is confirmed by the regional palynostratigraphical data so far available (Van de Laar, 1980; B. Jelen, Ljubljana, unpubl. notes). A tentative scheme of successive palynological phases in the Permian of the Southern Alps would even indicate that the basal beds of the Val Gardena Formation in the Dolomites and the Vicentinian Alps are younger than the top of the formation in Slovenia.

With regard to the classic problem on an age determination in terms of the European chronostratigraphical subdivision of the Permian (Autunian, Saxonian, Thuringian), palynological information clearly supports a Thuringian (Late Permian) age of the Val Gardena Formation (Visscher, 1971, 1973), at least in the Dolomites and the Vicentinian Alps. A direct translation of palynological information into the more refined ammonoidand/or fusulinid-based marine "standard" classifications of the Permian cannot yet be fully accomplished (Visscher, 1980).

Accepting the recent results of multidisciplinary investigations in Iran (Iranian-Japanese Research Group, 1981), there is now sufficient biostratigraphical background to adopt the succession Abadehian-DzhulfianDorashamian as the most realistic subdivision on the stage level of the upper part of the Permian System in the Tethys realm.

No diagnostic marine fossils are known from the Val Gardena Formation to recognize these stages in the Southern Alps. The neritic facies of the Bellerophon Formation, on the other hand, is highly fossiliferous; algae, foraminifera, molluscs and brachiopods are particularly well represented (review by Leonardi, 1967). The marine faunal record has long been seen to be related to those from other Late Permian formations in the Tethys realm. The presence of diagnostic brachiopods in the upper part of the Bellerophon Formation (Araxathyris, Janiceps, Comelicania) provides a direct correlation with the type-Dorashamian in Transcaucasia (Rostovtsev and Azaryan, 1973). Considering the partly lateral position of the Val Gardena Formation, it is probable that in the area of the Adige Valley the latter formation could also range into the Dorashamian. The main body of the formation in the Dolomites and the Vicentinian Alps, however, is likely to represent the Dzhulfian and Abadehian. Towards the east, the formation may become considerably older; in Slovenia a Middle Permian age is likely, 
since on the base of fusulinid evidence the overlying marine sediments are known to be of pre-Abadehian age. This picture seems to be justified by palynological considerations.

\section{LOCALITIES}

Throughout the areal extent of the Val Gardena Formation grey interbeds may sometimes be rich in plant fragments of variable size and preservation. The deposits consist of sandstones of variable grains, often grading into fine siltstones; the first type of deposits delivers larger plant fragments, the latter generally smaller but better preserved material, as well as reasonably preserved palynological assemblages.

Rich palaeobotanical and palynological collections were made during several excursions to the Dolomites and the Vicentinian Alps. Classic localities were relocated, several new localities were traced. Most localities delivered well-preserved material, that could be investigated by means of cuticle analyses. Also a fair amount of fertile material was collected. Localities relevant to the present study are listed hereafter; detailed descriptions of the sections in which the localities are situated have to await the publication of stratigraphically directed contributions to our project.

\section{Localities in the Dolomites}

Here two areas were investigated:

(1) The vicinity of Ortisei: (a) Cuecenes (Seceda); compare OgilvieGordon (1927, p.4) and Klaus (1963, fig.3). (b) Roncadizza; compare Klaus (1963, fig.4).

(2) The vicinity of Redagno; compare Klaus (1963) and Leonardi (1967). The bed of the Bletterbach is flanked by rich plant-bearing deposits. A high waterfall divides the canyon-like river bed into two sampling localities: (a) Butterloch, the upper area. Here fossil plant remains were collected at the northern river bank over a distance of about $200 \mathrm{~m}$ (code numbers R1 (upstream), R2, R3a, R3b, R4, R5-73, R5-74 (near top of waterfall). (b) Taubenleck, the lower area. Here two localities were traced in the north wall of the canyon in a streamlet (code numbers RTA, RTB). Further material was collected from downfallen rocks in the river bed [code numbers RTD (near base of waterfall), RTD1, RTD2, RTD3, RTD4, RTD5 downstream ].

\section{Localities in the Vicentinian Alps}

Here two areas were investigated (see De Boer, 1963, geological map):

(1) The vicinity of Recoaro Terme: U1be. Here plants were collected from rather coarse sandstones (code number U1be Z) and, about $20 \mathrm{~m}$ higher, from siltstones, overlain by dolomites (code number U1 be D).

(2) The vicinity of Valli di Pasubio: (a) Casarotti; (b) Cortiana, near stone cuttery; (c) Scocchi. 
The plant material collected mainly consists of compressions, often preserved with cuticles. With the exception of a few shoot systems and cones, the remains are of rather fragmentary nature (dispersed shoots, leaves, bracts, ovuliferous dwarf-shoots etc.).

In terms of the conventional nomenclature applied in the classification of West European Permian plants, the most common genera found in the assemblages studied are the following: (1) pteridosperms, traditionally included within Callipteris (C. martinsii) and Sphenopteris; (2) the ginkgoalean genus Sphenobaiera; and (3) the conifers Ullmannia, Pseudovoltzia, Quadrocladus. In addition the assemblages are characterized by the frequent and sometimes even dominant occurrence of the conifer Ortiseia, originally described by Florin (1964) from the Val Gardena Formation (Cuecenes, Seceda).

TECHNIQUES, STORAGE AND TERMINOLOGY

\section{Techniques}

Fossil-bearing fragments of siltstone were macerated by a treatment with Schulze reagent for some weeks, then washed in $\mathrm{H}_{2} \mathrm{O}$ and transferred to a dilute solution of $\mathrm{NH}_{4} \mathrm{OH}$ (bulk maceration). For fragments with a sandy matrix, a treatment with cold $45 \% \mathrm{HF}$ for one to two days preceded the maceration. Selected fossil remains were mounted in glycerine jelly and sealed with paraffin. For rather thick fragments concave-grinded object glasses were used. Larger plant fossils have been investigated by taking cuticle fragments directly from the slab and macerating these in tubes. Also pollen grains have been collected either by bulk maceration, or by treating fragments of polliniferous cones.

\section{Storage}

The collected material and permanent slides are stored in the collections of the Laboratory of Palaeobotany and Palynology of the State University of Utrecht, The Netherlands. The holotype of Ortiseia leonardii Florin 1964 is stored in the Gësa di Ladin's Museum, Ortisei, Val Gardena, Italy.

\section{Terminology}

Since there is great variety in the descriptive terminology of various authors, some terms used in the present study are explained hereafter.

\section{Terminology of elements of ovuliferous cones}

Bract: A foliar appendage of the cone axis.

Ovuliferous dwarf-shoot: A lateral branch of limited growth, arising in the bract axil.

Scale: A foliar appendage of an ovuliferous dwarf-shoot; they can be divided into (a) sterile scales and (b) fertile scales (ovule-bearing foliar appendages). 
Ovule/seed: Because only cuticles are preserved, it is not possible to distinguish with certainty in the present material between ovules and seeds. The dispersed specimens differ from those found attached to ovuliferous dwarf-shoots in being larger, especially with respect to the integumentary extensions. For practical purposes an ovule may be regarded as found attached to ovuliferous dwarf-shoots, whereas seeds represent specimens found dispersed.

Terminology of cuticle structures (see also Figs. 1 and 2)

A cuticle can reflect epidermal structure (two-dimensional) and/or shows its own structure (idiocuticular characteristics).

Stoma: Stomatal aperture together with the guard cells.

Subsidiary cells: Cells enclosing the stoma.

Stomatal complex: Stoma together with subsidiary cells.

Dicyclic stomatal complex: Stoma enclosed by two rings of cells; the inner ring is formed by the subsidiary cells, the outer ring by the encircling cells.

Epidermal papillae: Papillae ornamenting the epidermal cells; they can be hollow (reflecting an epidermal structure) or solid (representing a cuticular structure).

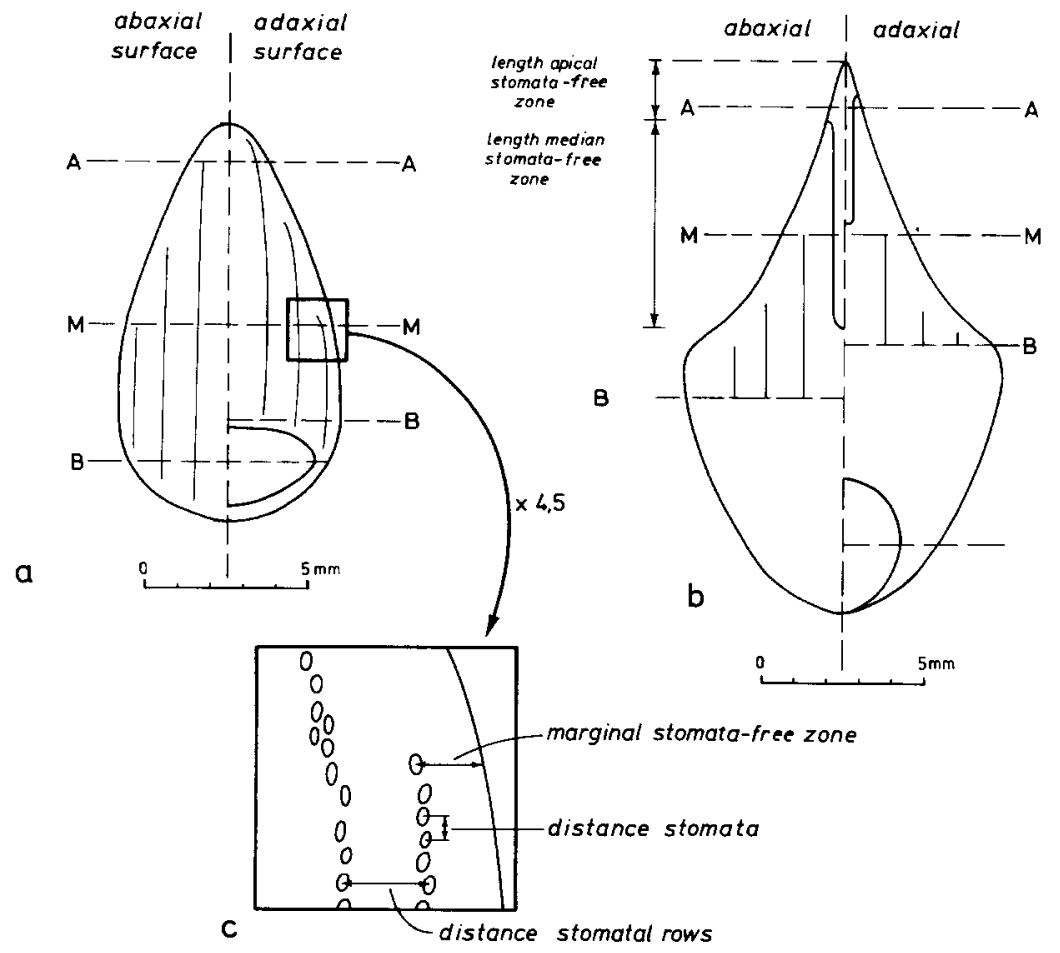

Fig.1. Applied measurements: a, leaf; b, bract; c, detail leaf. $A, M, B$ represent measurements in apical, median and basal part of stomatiferous area and correspond with $A, M$ and $B$ on Table II. 


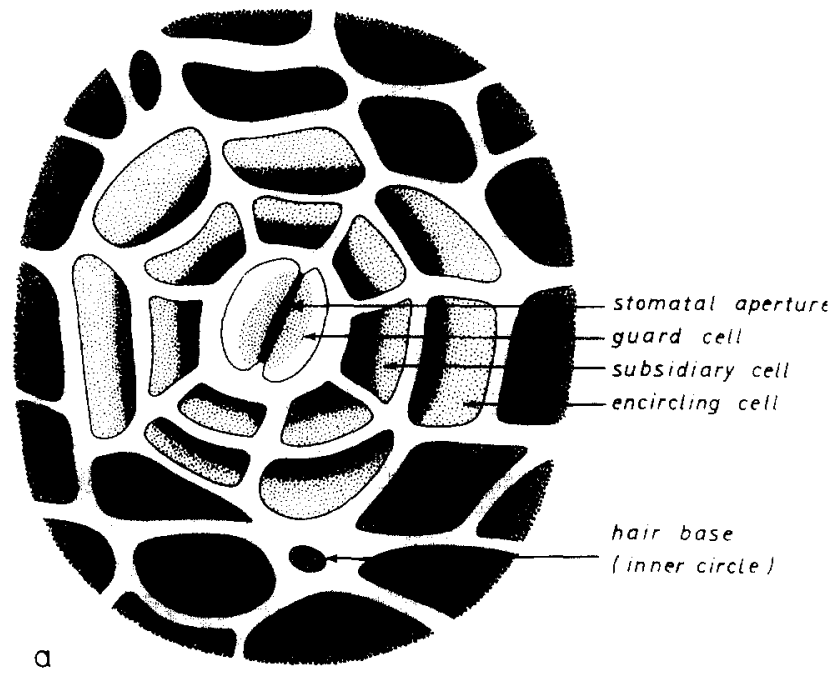

0 $25 \mu \mathrm{m}$

b

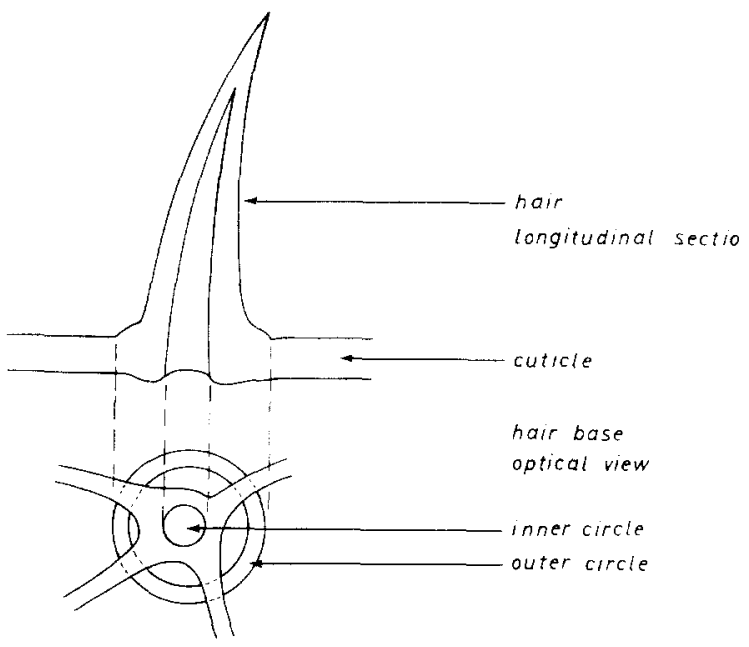

Fig. 2. Organization of stomatal complex and hair. a. Organization and terminology of stomatal complex. b. Organization of hair (longitudinal section) and hair base (optical view).

\section{THE GENUS ORTISEIA}

The genus Ortiseia has been described by Florin (1964) from the Val Gardena Formation. The original diagnosis of the genus is quoted here, because of the relative obscurity of the publication concerned: 
"Holzgewächse. Laterale Spross-Systeme fiederartig verzweigt, aus je einem Spross vorletzter Ordnung und zahlreichen unverzweigten, abstehenden und zweizeiligen, axillären Seitensprossen aufgebaut. Sprosse vorletzter Ordnung mit allseitswendigen, bifazialen, spiralig gestellten und meist abstehenden, ledrigen Blättern bekleidet, diese breit verkehrt-eirund bis schmal eirund, einfachspitzig, spitz oder kurz zugespitzt und an der Achse herablaufend. Seitensprosse letzter Ordnung mit allseitswendigen bifazialen spiralig gestellten, abstehenden bis fast gespreizten, ledrigen Blättern bekleidet. Sie sind einadrig, schmal eirund, unterseits gewölbt, stumpf oder spitz bis zugespitzt, und laufen an der Achse herab.

Blätter der Seitensprosse letzter Ordnung amphistomatisch, auf beiden Blattseiten mit mehr oder weniger regelmässig verlaufenden, meist einfachen, nicht zu Streifen vereinigten Längsreihen von Spaltöffnungsapparaten. Diese haplocheil, amphizyklisch (dizyklisch) mit meist 5-7, die Atemhöhle nicht überwölbenden Nebenzellen und gleich vielen, distalwärts stark verdickten Kranzzellen versehen.

Kurze Kutikularpapillen auf der Blattoberseite und einzellige Haarbasen auf beiden Blattseiten - ausserhalb der Spaltöffnungsapparate - vorhanden. Antiklinalwände der Epidermiszellen gerade und eben. Blattränder zum Teil uneben.

Typus der Gattung: O. leonardii n.sp."

Since this diagnosis does not include the ovuliferous organs, necessary for assigning a natural status to a fossil conifer genus, it is here considered that Ortiseia in its original concept ought to be regarded as a form-genus.

The genus Ortiseia, after its publication, has been hardly taken into consideration in subsequent palaeobotanical work on the Alpine Permian (compare, e.g., Remy and Remy, 1978). Application of the name for identification of specimens other than the holotype is virtually confined to Leonardi's (1967) citation of (unpublished) work by Charrier and to a publication by Jung (1977).

In the outer Alpine Permian, the occurrence of Ortiseia has never been reported. However, during the course of the present investigations, it became clear that Ortiseia shows resemblance with Culmitzschia, a form-genus, on the basis of some shoots and dispersed cuticle fragments described by Ullrich (1964) from the German Zechstein. On the form-genus level, the two genera could well be regarded as synonyms.

On the form-genus level, therefore, the question of nomenclatorial priority has to be considered. Both Florin and Ullrich published their studies in 1964. On Ullrich's publication the date of issue has been indicated as October 1964. Although the exact month could not be traced, Florin's publication has been issued in the summer of 1964, according to information collected in Stockholm and Ferrara. Consequently, on the form-genus level, Culmitzschia should be regarded as a synonym of Ortiseia.

However, because the rich material collected enabled the present author not only to study the sterile remains of three species of Ortiseia in detail, but also their fertile parts, the generic diagnosis of Ortiseia is emended to constitute a natural conifer genus, rather than a form-genus. Consequently the name Culmitzschia may well remain a practical taxon for classifying sterile remains at a form-genus level; the form-genus will be separately treated (pp. 112-115). 
Genus Ortiseia Florin 1964, emend.

Type-species: Ortiseia leonardii Florin 1964

Holotype of the type-species: Ortiseia leonardii Florin 1964, plate I

Emended diagnosis: Conifer. Presumed main axis leafy at younger stage. Pinnately branched lateral shoot systems, consisting of a penultimate branch with two lateral series of parallel, more or less alternating ultimate branches, situated in one plane. Bifacial leaves spirally arranged, not or slightly overlapping, arising at an angle of $20-80^{\circ}$, straight or spreading at an angle of $\max .90^{\circ}$; shape triangular, oblong, ovate or lanceolate, apex sometimes slightly curving upward, acute to obtuse. Leaf base slightly contracted, sometimes only abaxially, elliptical or circular in section.

Ovuliferous cones compound, cylindric. Cone axis bearing spirally arranged bracts, slightly overlapping; shape of bracts rhomboid or obovate, apex acute or acuminate.

Ovuliferous dwarf-shoots freely arising in bract-axils, flattened, usually bilaterally symmetrical, provided with a large number $(20-30)$ of sterile scales and a single fertile scale (megasporophyll), more or less centrally emerging on the adaxial side. Fertile scale bearing one inverted ovule in the middle of its abaxial surface. In basal part of dwarf-shoot scales hardly connate; towards apical part more coalescent, notably on the abaxial side.

Ovule/seed bilaterally symmetrical, platyspermic, ovate, sometimes elliptical, showing several integumentary extensions. Basal part of integument extending into two lateral horn-shaped differentiations and one medianobverse triangular or rotund differentiation, bordering the hilum; on the reverse side, opposite the hilum occurs a transversal often doubled seam of small protrusions. Apical (micropylar) area obtuse. Nucellus ovate, free to its base; pollen/archegonial chamber present. Megaspore membrane cutinized.

Polliniferous cone simple. Cone axis bearing numerous spirally arranged subpeltate microsporophylls, slightly overlapping. Proximal part of microsporophyll arising at an angle of approximately $90^{\circ}$, elliptical in section. Distal part narrow-subtriangular, basally rounded, apex acute, parallel to the cone axis or slightly divergent.

Prepollen circular to elliptical in polar view; diameter 150-300 $\mu \mathrm{m}$. Nexine smooth. Sexine with alveolate infrastructure, uniformly fused to nexine. Equatorial sexine expanded to a flattened distally pendent monosaccoid differentiation. Proximal trilete mark developed in both nexine and sexine. No distal germinal area.

Epidermis of axes with scattered stomata; epidermal cells isodiametric. Epidermis of leaves, bracts, scales and microsporophylls amphistomatic. Marginal and sometimes median and apical zones, further basal scales of ovuliferous dwarf-shoots, basal parts of bracts and proximal part of microsporophylls non-stomatiferous; on adaxial surface of bracts stomatal rows starting a few millimetres more apically than on abaxial surface. Stomata 
generally arranged in longitudinal rows, sometimes doubled over some distance. Adjacent stomatal complexes regularly occurring.

Epidermis of integument sometimes showing scattered stomata.

Stomatal complexes dicyclic, seldom mono- or tricyclic; guard cells sunken, four to eight subsidiary cells, trapezoid, proximal and distal walls thickened, proximal walls may form a rim, surrounding the stoma, sometimes bearing solid papillae; subsidiary cells surrounded by a similar number of encircling cells, also trapezoid, with strongly thickened distal walls. Epidermal cells rather small, isodiametric-quadrangular on leaf bases and in stomatal rows; in stomata-free zones between the rows rectangular or irregularly stretched, shorter on adaxial leaf surfaces. Epidermal cells sometimes provided with solid papillae. Anticlinal walls straight.

Hair bases abundant; hairs unicellular.

Cuticle thick, 5-10 $\mu \mathrm{m}$, measured halfway along an abaxial leaf surface.

Remarks: Apart from the extension of the original diagnosis with the description of the (presumed) main axis with leaves, ovuliferous and polliniferous cones, ovules (seeds) and prepollen, the emendation has been founded on the following observations: (1) the leaves proved to be non-decurrent on the axis. (2) papillae, if present, occur not only on epidermal cells of adaxial surfaces, but also on epidermal cells of abaxial surfaces as well as on subsidiary cells.

Charrier (1964) gave a detailed description of structurally preserved silicified wood, found at the locality "Cuecenes" (Seceda). He established a new taxon, Dadoxylon schrollianum f. atesinum Charrier 1964, which he regarded as representing the wood of Ortiseid. This assumption, however, was not based on organic connection or on direct depositional association. Therefore, in the present emended diagnosis the wood has not been taken into consideration.

Ortiseia leonardii Florin 1964, emend. (Plates I-XI*; Figs.3, 4, 12, 13, 15)

Holotype: Specimen 1/mo, Gësa di Ladin's Museum, Ortisei, Val Gardena, Italy. Florin (1964, plate I), Leonardi (1967, plate XI, 1), present paper (Plate I).

Locus typicus: Cuecenes (Seceda).

Stratum typicum: Val Gardena Formation.

Emended diagnosis: Pinnately branched lateral shoot systems, consisting of a penultimate branch with two lateral series of parallel, more or less alternating, ultimate branches, situated in one plane. Leaves hardly overlapping, arising at an angle of $20-45^{\circ}$, spreading at an angle of max. $90^{\circ}$; shape triangular (only at presumed main axis), oblong or ovate, apex acute to obtuse, sometimes slightly curved upward; observed length 6-35 $\mathrm{mm}$. Leaf base slightly contracted abaxially, elliptical in section.

*For Plates, see pp. 122-162. 


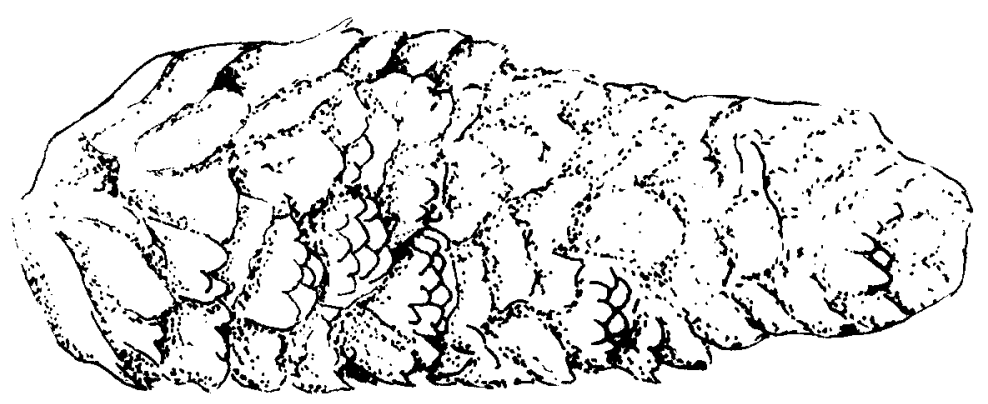

Fig. 3. Explanatory sketch of ovuliferous cone of Ortiseia leonardii, drawn after Plate II, 4.

Ovuliferous cone at least $6 \mathrm{~cm}$ long, $2 \mathrm{~cm}$ wide. Cone axis bearing spirally arranged bracts, slightly overlapping; shape of bracts rhomboid, apex acute, up to $17 \mathrm{~mm}$ long.

Ovuliferous dwarf-shoots (nearly) bilaterally symmetrical, up to $15 \mathrm{~mm}$ long, $11 \mathrm{~mm}$ wide, not reaching apex of subtending bract. Dwarf-shoots provided with at least 25 sterile scales and a single fertile scale, emerging approximately centrally on the adaxial side. Shape of sterile scales variable, ranging from lanceolate to obovate towards the apical part of the dwarfshoot. Fertile scale rhomboid, with an obtuse apex, projecting beyond the sterile scales.

Ovule/seed ovate, up to $13 \mathrm{~mm}$ long. Basal part of integument extending into two lateral horn-shaped differentiations and one median-obverse triangular (rarely rotund) differentiation, bordering the hilum; on the reverse side, opposite the hilum, occurs a transversal, often doubled seam of protrusions, a few millimetres high. Apical (micropylar) end obtuse. Nucellus ovate, free to its base; pollen/archegonial chamber present. Megaspore membrane cutinized.

Polliniferous cone cylindric, at least $7 \mathrm{~cm}$ long, $2 \mathrm{~cm}$ wide. Cone axis bearing numerous spirally arranged microsporophylls. Proximal part of microsporophyll arising at an angle of approximately $90^{\circ}$, length $7-8 \mathrm{~mm}$, elliptical in section. Distal part narrow-subtriangular, approximately $10 \mathrm{~mm}$ long, 5-6 mm wide, parallel to cone axis or slightly divergent.

Prepollen circular in polar view; mean diameter approximately $200 \mu \mathrm{m}$; mean width of monosaccoid differentiation $25 \mu \mathrm{m}$.

Basal part of bract non-stomatiferous for about half of the abaxial surface; basal scales of ovuliferous dwarf-shoots (approximately eleven scales) and proximal part of microsporophyll non-stomatiferous.

Stomata generally arranged in crowded rows, sometimes doubled over some distance, especially on adaxial surfaces of leaves. Adjacent stomatal complexes frequent, sometimes sharing an encircling cell, rarely a subsidiary cell. Mean distance of stomatal rows, measured halfway along a single abaxial surface varying between 160 and $260 \mu \mathrm{m}$ (6-9 epidermal cells), on adaxial surfaces between 140 and $270 \mu \mathrm{m}$ (5-9 epidermal cells). Frequency of stomata on adaxial surfaces slightly higher than on abaxial surfaces. 

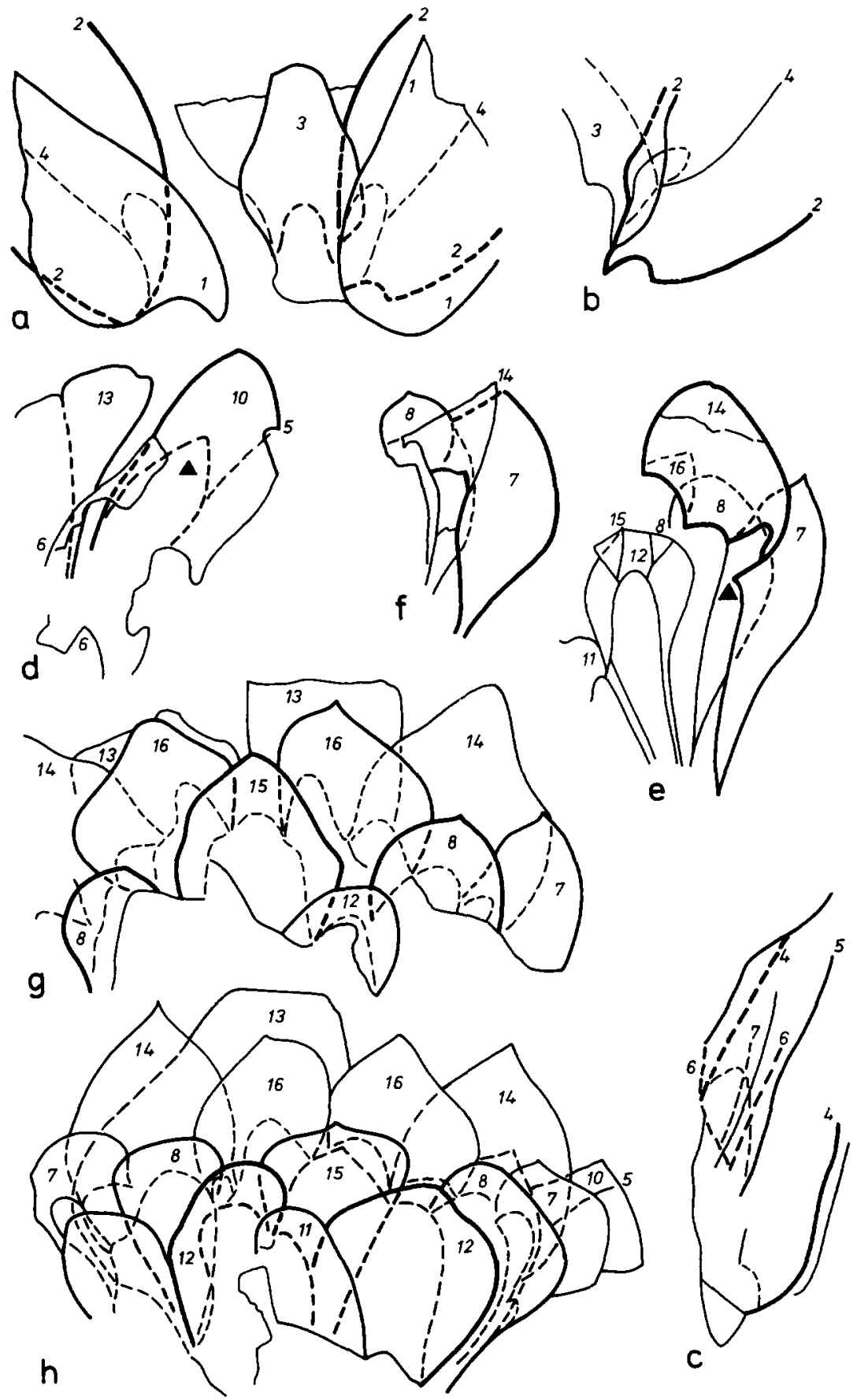

Fig.4. Explanatory sketches, drawn after photographs of (fragments of) ovuliferous dwarf-shoots, belonging to Ortiseia leonardii. Because of the translucency of the macerated material, the photographs cannot picture the place (adaxial or abaxial) of scale insertion. The numbering of scales corresponds with that on Fig.14 (organization of ovuliferous dwarf-shoots). The interrupted lines outline the underlying scales; the view is adaxial or abaxial with respect to the cone axis. a. After Plate VII, 1c, adaxial view. b. After Plate VII, 2, abaxial view. c. After Plate VII, 5, abaxial view. d. After Plate VII, $4 \mathrm{a}$, adaxial view. e. After Plate VII, $4 \mathrm{~b}$, adaxial view. (d and e represent detached parts of a single fragment; the triangles mark place of detachment.) f. After Plate VII, 6, adaxial view. g. After Plate VIII, 1a, abaxial view. h. After Plate VIII, 4, abaxial view. 


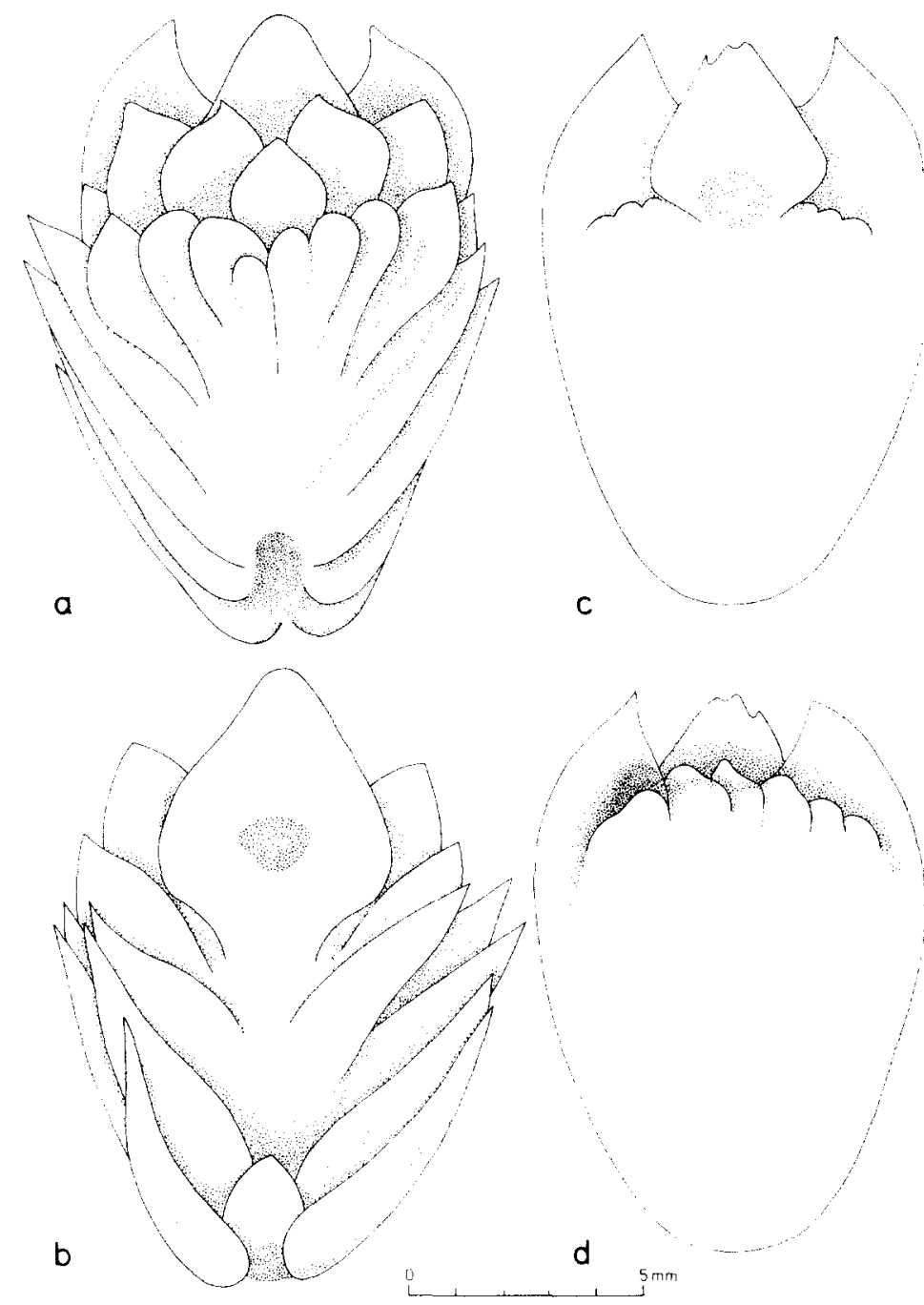

Fig. 5. Reconstruction of ovuliferous dwarf-shoot and ovule of Ortiseia leonardii. a. Dwarf-shoot with ovule, abaxial view. b. Dwarf-shoot, ovule detached. c. Ovule, obverse view. d. Ovule, reverse view.

Marginal stomata-free zones rather narrow on leaves $(250-750 \mu \mathrm{m})$, wider on bracts and distal parts of microsporophylls $(1-2 \mathrm{~mm})$. Apical and median stomata-free zones present on leaves of presumed main axis, bracts and distal parts of microsporophylls; apical zones 1-2 $\mathrm{mm}$ long, median zones, occurring near apex $0.7-2 \mathrm{~mm}$ long, but longer on abaxial surfaces of bracts.

Basal part of integument showing scattered stomata.

Stomatal complexes dicyclic, sometimes incompletely tricyclic. Guard cells slightly sunken. Proximal walls of subsidiary cells forming an even rim, mostly bearing solid papillae; distal walls straight to concave. Mean 
number of subsidiary cells per stomatal complex, measured on a single surface, rather constant (5.7-6).

Distal walls of encircling cells straight to concave.

Anticlinal walls of epidermal cells approximately $3 \mathrm{~mm}$ wide, sometimes thickened in stomatal rows. Epidermal papillae regularly occurring on leaves, distal parts of microsporophylls, ovuliferous dwarf-shoots (strongly papillate) and integuments; papillae apparently absent on main axes, axes of penultimate branches and bracts.

Hairs cylindric.

Exterior of cuticle without cellular pattern. Cuticle approximately $5 \mu \mathrm{m}$ thick, measured halfway along an abaxial leaf surface.

Material and supplementary descriptions (Plates I-XI; Figs. 1-5, 12-15, 17; Tables I-V)

Material: Apart from Florin's (1964) holotype, representing a lateral shoot system (Plate I), the following new material from various localities (see Table IV) was studied in detail: (1) several presumed main axes, with fragments of cuticle; (2) a few slabs, showing parallel situated shoots, probably ultimate branches, belonging to a single lateral shoot system; (3) several penultimate branches, one specimen showing an attached ultimate branch, numerous ultimate branches; (4) numerous leaves, originating from presumed main axes, penultimate and ultimate branches; $(5)$ three detached ovuliferous cones, several dispersed (more or less complete) ovuliferous dwarf-shoots, sometimes with bract and/or ovule, dispersed bracts and seeds; and (6) five detached polliniferous cones, some small cone fragments and several dispersed distal parts of microsporophylls.

Supplementary descriptions: Presumed main axes (Plate III, 1-2; Fig.12): Largest fragments approximately $10 \mathrm{~cm}$ long, $5-6 \mathrm{~cm}$ wide. Leaves, only found dispersed, triangular, apex acute, up to $17 \mathrm{~mm}$ long and $11 \mathrm{~mm}$ wide.

Penultimate branches (Plate I; Plate II, 1; Plate III, 3; Plate IV; Plate V, 1-2; Fig.12): Largest fragment $38 \mathrm{~cm}$ (holotype). Axes 8-12 $\mathrm{mm}$ wide, axes together with leaves up to $50 \mathrm{~mm}$. Leaves arising and spreading at angles of $20-45^{\circ}$ and $\max .90^{\circ}$ respectively, apex acute; $12-35 \mathrm{~mm}$ long, up to $8 \mathrm{~mm}$ wide.

Ultimate branches (Plate I; Plate II, 2-3; Plate V, 3-6; Plate VI, 1; Plate XI, 1-2; Fig.12): Arranged at an angle of $45-60^{\circ}$ on the penultimate branch with interspaces of $10-25 \mathrm{~mm}$, length $10-20 \mathrm{~cm}$. Axes $3-5 \mathrm{~mm}$ wide, axes together with leaves up to $25 \mathrm{~mm}$. Leaves arising and spreading at angles of $30-45^{\circ}$ and $60-80^{\circ}$ respectively, elliptical or ovate, apex obtuse or acute, sometimes slightly curved upward; 6-15 $\mathrm{mm}$ long, $4-7 \mathrm{~mm}$ wide.

Ovuliferous cones (Plate II, 4; Fig.3) approximately $6 \mathrm{~cm}$ long, 2--3 cm wide. Observed width of cone axis $8 \mathrm{~mm}$.

Ovuliferous dwarf-shoots (Plate VII; Plate VIII; Plate XI, 3; Figs.4-5, 13-14): Specimens isolated from cones $11-13 \mathrm{~mm}$ long, about $10 \mathrm{~mm}$ wide; dispersed dwarf-shoots up to $15 \mathrm{~mm}$ long, $11 \mathrm{~mm}$ wide. Size, shape and sequence (from basal to apical part of dwarf-shoot) of scales have been 
visualized in Fig.14; explanatory sketches after photographs are given in Fig.4; a reconstruction of the dwarf-shoot is shown in Fig.5.

Ovules/seeds (Plate VIII, 5; Plate IX; Plate X, 1; Figs.5, 13, 15, 17): Specimens, isolated from cones, 10-12 mm long, 8-10 mm wide; lateral differentiations $4 \mathrm{~mm}$ long, 3-4 $\mathrm{mm}$ wide; median differentiation $3-4 \mathrm{~mm}$ long, 3-4 mm wide. Dispersed specimens up to $14 \mathrm{~mm}$ long, $11 \mathrm{~mm}$ wide; lateral differentiations $4-5 \mathrm{~mm}$ long, $4-5 \mathrm{~mm}$ wide, median differentiation up to $5 \mathrm{~mm}$ long, $7 \mathrm{~mm}$ wide.

Polliniferous cones (Plate II, 5): The cones found show little variation. The largest specimen, probably a complete cone, is $7.5 \mathrm{~cm}$ long, nearly $2 \mathrm{~cm}$ wide. Situation and number of pollen sacs so far unknown. Cone axis about $4 \mathrm{~mm}$ wide.

Microsporophylls, distal parts (Plate X, 2-4; Fig.12): Dimensions rather constant.

Prepollen (Plate X, 5): Corresponding to the palynological form-genus Nuskoisporites Potonié et Klaus 1954; the prepollen will be described and discussed in a separate paper.

Epidermis of axes (Plate III, 2): For frequency of stomata, mean number of subsidiary cells per stomatal complex, occurrence of papillae and frequency of hair bases, see Table I.

Epidermis of leaves, bracts and distal parts of microsporophylls (for

\section{TABLE I}

Frequency of stomata, number of subsidiary cells/stomatal complex, occurrence of papillae and frequency of hair bases on axes of Ortiseia leonardii, O. visscheri and O. jonkeri

\begin{tabular}{|c|c|c|c|c|c|c|c|c|c|c|c|}
\hline \multirow{2}{*}{\multicolumn{2}{|c|}{ AXES }} & \multicolumn{8}{|c|}{ STOMATAL COMPLEXES } & \multirow[b]{2}{*}{ 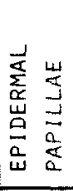 } & \multirow{2}{*}{$\begin{array}{l}\text { HAIR BASES } \\
\text { frequency } \\
\text { per mm2 }\end{array}$} \\
\hline & & $\begin{array}{l}\text { frequency } \\
\text { per } \mathrm{nm} 2 \\
\end{array}$ & \multicolumn{4}{|c|}{$\begin{array}{l}\text { distribution } \\
\text { according to } \\
\text { number of subs. } \\
\text { cells }\end{array}$} & 8 & $\begin{array}{l}\text { mean } \\
\text { number } \\
\text { subs. } \\
\text { cells/ } \\
\text { stomatal } \\
\text { complex } \\
\end{array}$ & $\begin{array}{l}0 \\
0 \\
0 \\
-1 \\
0 \\
0 \\
0 \\
0 \\
0\end{array}$ & & \\
\hline 武 & ma in & 10 & & 32 & 52 & 16 & & 5.84 & + & - & 200 \\
\hline 앴 & penult. & $12-15$ & 4 & 36 & 36 & 24 & & 5.80 & + & - & 350 \\
\hline d & wit. & $30-40$ & 4 & 28 & 68 & & & 5.64 & + & + & 350 \\
\hline $\overrightarrow{\mathrm{c}}$ & main & & & & & & & & & & \\
\hline 농 & penult. & $30-40$ & & & 40 & 60 & & 6.60 & - & - & 450 \\
\hline$\geqslant$ & wite. & 40 & & 6 & 40 & 50 & 4 & 6.52 & - & - & 450 \\
\hline$\vec{a}$ & ntai in & 8 & & 8 & 32 & 48 & 12 & 6.64 & + & - & 250 \\
\hline$\S$ & penult. & $20-36$ & & & 48 & 32 & 20 & 6.72 & + & - & 250 \\
\hline $0^{\circ}$ & uit. & $40-60$ & & & 44 & 44 & 12 & 6.68 & + & + & 450 \\
\hline
\end{tabular}


plate references see above-mentioned descriptions of the elements concerned; Fig.12): Stomata generally situated in diverging, parallel and/or converging rows. Orientation of stomata transversal or longitudinal, sometimes oblique.

Epidermis of scales of ovuliferous dwarf-shoots (Plate VIII, 1b): Stomata scattered or in short rows.

Epidermis of integuments (Plate IX, 4; Plate X, 1): Some stomata present, especially on lateral differentiations.

Arrangement of stomata rather constant per individual element (leaves of presumed main axes, penultimate and ultimate branches, respectively; bracts scales and distal parts of microsporophylls) see Table II.

For marginal stomata-free zones see Plate III, 1b; Plate IV, 2a and 3; Fig.12. For apical stomata-free zones see Plate III, 1a; Plate VI, 2a; Plate X, $3 \mathrm{~b}$; Fig.12. For median stomata-free zones see Plate III, 1a; Plate VI, 2a and 3; Plate X, 3b; Fig.12. For dimensions of stomata-free zones see Figs.1, 12; Table II. A detailed organization of the stomatal complex is reconstructed in Fig.2a; further see Plate IV, 2c; Plate V, 2; Plate XI, 1b and 2b.

Epidermal papillae about $8 \mu \mathrm{m}$ in diameter (see Plate III, 1c; Plate IV, 2b; Plate V, 2; Plate VIII, 6a; Plate X, 4; Plate XI, 1a and 3).

Hair bases recognizable as two concentric circles; the smaller $(9 \mu \mathrm{m})$ situated on both sides of the cuticle, the larger $(20 \mu \mathrm{m})$ only on the exterior side (see Plate IV, 2b-c; Plate VI, 1 and 2b; Plate VIII, 1b; Plate XI, 1- 2; Fig.2b). Hairs about $65 \mu \mathrm{m}$ long (see Plate VIII, 6; Plate XI, 3; Fig.2b).

For frequency of stomata, mean number of subsidiary cells/stomatal complex, mean dimensions of epidermal cells, occurrence of papillae and frequency of hair bases, see Table III.

Ortiseia visscheri nov. sp. (Plates XII-XIX; Figs.6, 7, 12, 13, 15)

Holotype: Specimen 14107, Laboratory of Palaeobotany and Palynology of the State University of Utrecht, The Netherlands.

Locus typicus: Butterloch.

Stratum typicum: Val Gardena Formation.

Derivatio nominis: Dr. H. Visscher, Professor of Palaeobotany and Palynology, Utrecht.

Diagnosis: Shoot systems so far unknown. Leaves slightly overlapping, arising at an angle of max. $45^{\circ}$, straight; shape triangular (only at presumed main axis) or ovate, apex acute to obtuse; observed length 5-17 mm; leaf base slightly contracted abaxially, approximately circular in section.

Ovuliferous cones so far unknown.

Shape of bracts rhomboid with acute apex; length up to $18 \mathrm{~mm}$.

Ovuliferous dwarf-shoots bilaterally symmetrical, up to $15.5 \mathrm{~mm}$ long, $11.5 \mathrm{~mm}$ wide, reaching apex of subtending bracts. Dwarf-shoots provided with about 22 sterile scales and a single fertile scale, emerging slightly under the centre on the adaxial side. Shape of sterile scales variable, ranging from 


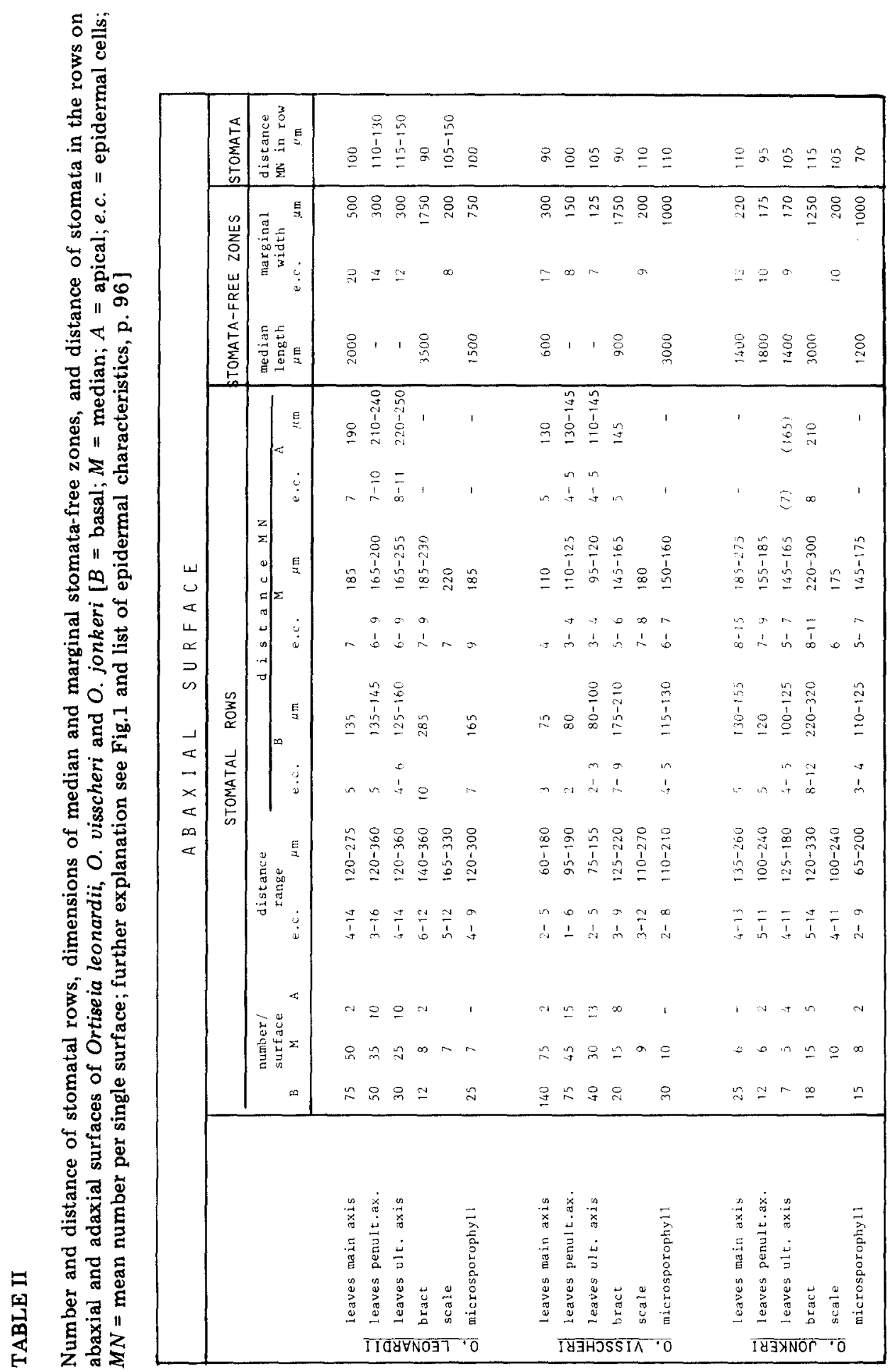




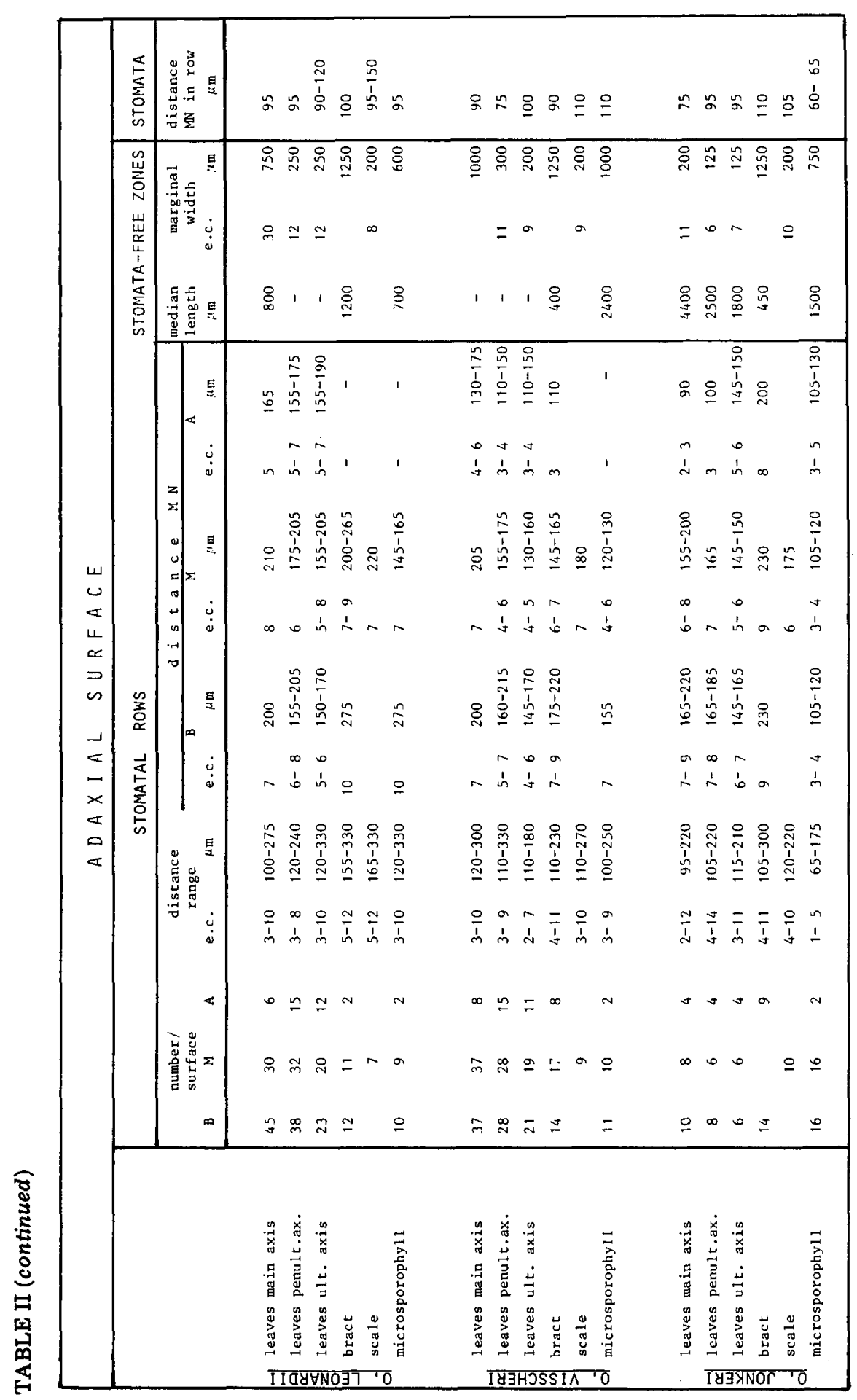




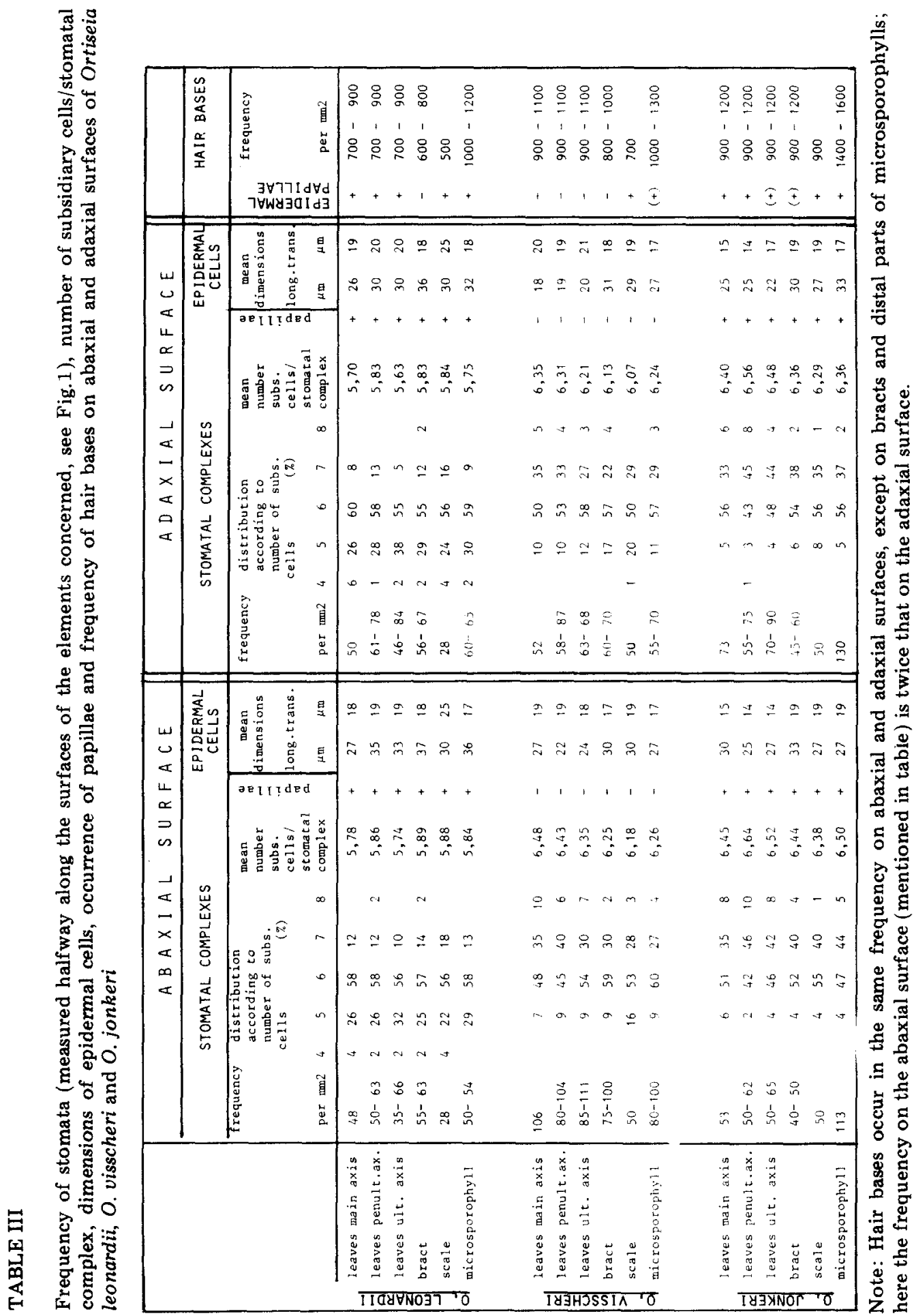




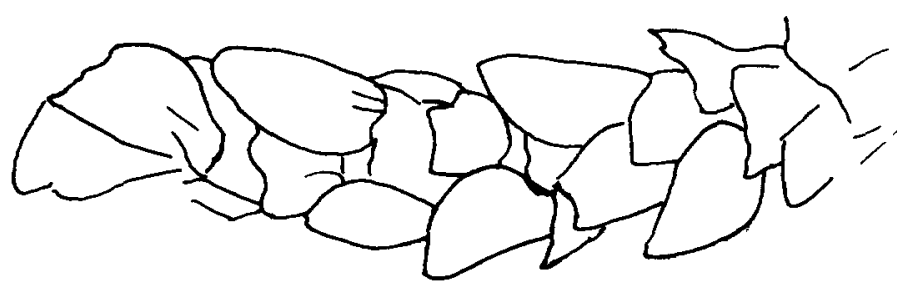

Fig.6. Explanatory sketch of holotype of Ortiseia visscheri, drawn after Plate XII, 1.

lanceolate to oblong towards the apical part of the dwarf-shoot. Fertile scale obovate with a truncate apex, sometimes with irregular margin, projecting beyond the sterile scales.

Ovule/seed, estimated length (the micropylar part is so far unknown) about $18 \mathrm{~mm}$. Basal part of integument extending into two lateral strongly curved horn-shaped differentiations and one median-obverse rotund differentiation, bordering the hilum; on the reverse side, opposite the hilum, occurs a transversal, often doubled seam of protrusions, a few millimetres high.

Adhering microsporophylls indicating a spirally arrangement. Distal part narrow-subtriangular, approximately $15 \mathrm{~mm}$ long, 5-6 $\mathrm{mm}$ wide. Proximal part and cone axis so far unknown.

Prepollen circular to slightly elliptical in polar view, mean diameter approximately $280 \mu \mathrm{m}$; mean width of monosaccoid differentiation $60 \mu \mathrm{m}$.

Basal part of bracts non-stomatiferous for about half of the abaxial surface; basal scales of ovuliferous dwarf-shoots (approximately eleven scales) and integument non-stomatiferous.

Stomata generally arranged in crowded rows, sometimes doubled over some distance, especially on adaxial leaf surfaces. Stomata on basal part of abaxial leaf surface so crowded that arrangement in rows is hardly recognizable. Adjacent stomatal complexes frequent, rarely sharing an encircling cell. Mean distance of stomatal rows, measured halfway along a single abaxial surface, varying between 90 and $180 \mu \mathrm{m}$ (3-8 epidermal cells), on adaxial surfaces between 130 and $210 \mu \mathrm{m}$ (4-7 epidermal cells). Frequency of stomata on adaxial surfaces lower than on abaxial surfaces.

Marginal stomata-free zones rather narrow on leaves $(125-300 \mu \mathrm{m}$ on abaxial surfaces, 200-1000 $\mu \mathrm{m}$ on adaxial surfaces) and distal parts of microsporophylls $(700-1000 \mu \mathrm{m})$, wider on bracts $(1-2 \mathrm{~mm})$. Apical and median stomata-free zones usually present on leaves of presumed main axes, bracts and distal parts of microsporophylls, especially on abaxial surfaces; apical zones $0.25-2 \mathrm{~mm}$ long, median zones, occurring near apex, $0.4-2 \mathrm{~mm}$ long, but possibly longer on abaxial surfaces of bracts and distal parts of microsporophylls.

Stomatal complexes dicyclic, sometimes incompletely tricyclic; guard cells slightly sunken; proximal walls of subsidiary cells sometimes forming a rim, even or slightly bulging, but never bearing papillae; distal walls slightly convex to straight. Mean number of subsidiary cells per stomatal complex, measured on a single surface, rather constant $(6.1-6.5)$. 


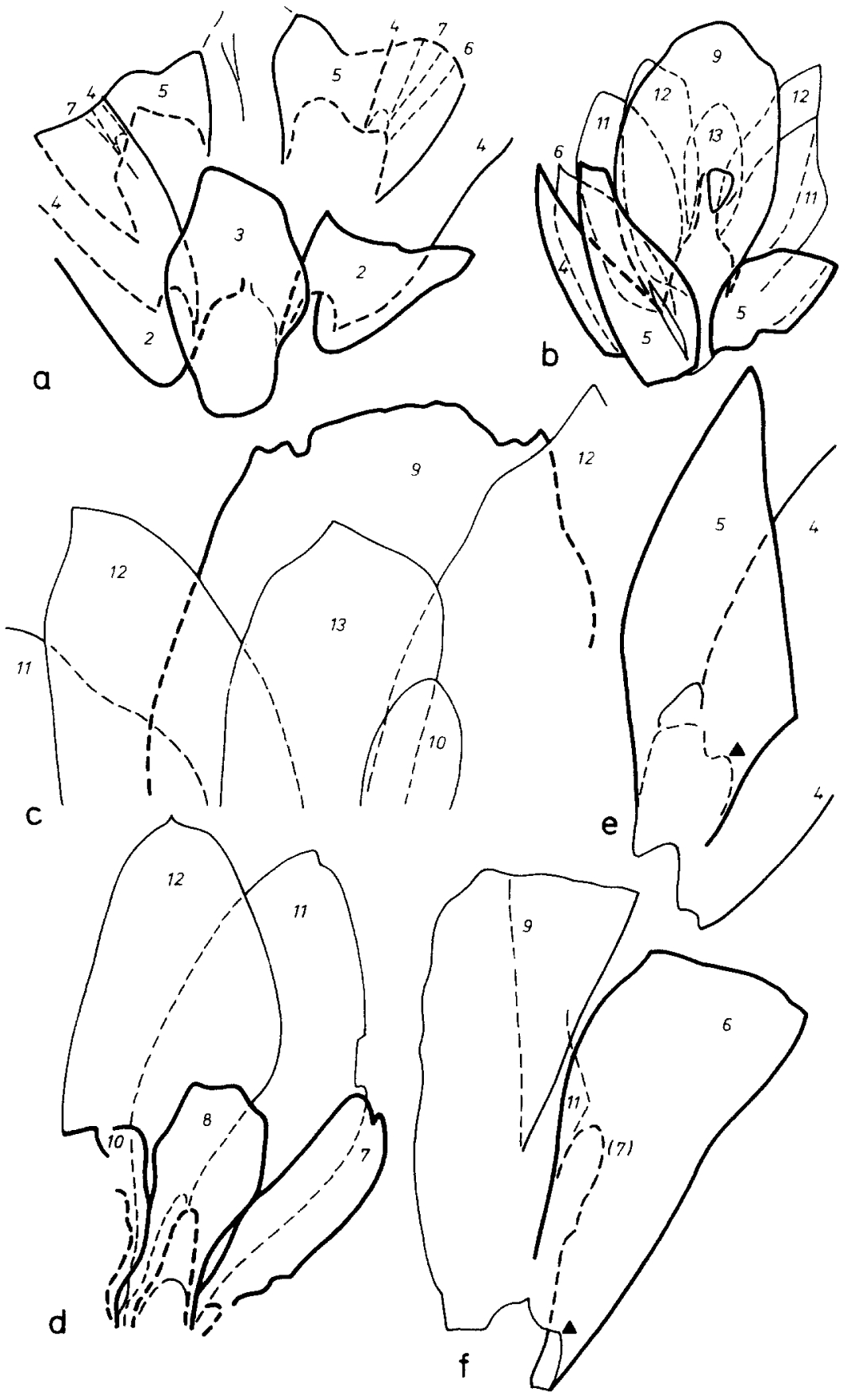

Fig. $7 a-f$. 

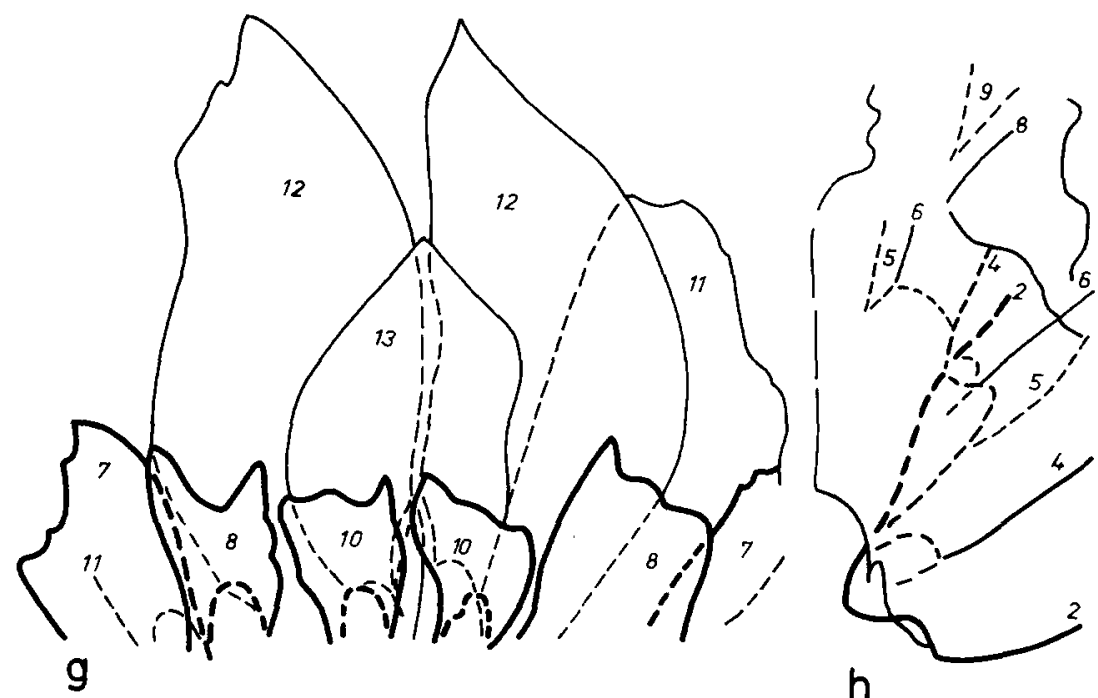

Fig.7. Explanatory sketches, drawn after photographs of (fragments of) ovuliferous dwarf-shoots, belonging to Ortiseia visscheri. Because of the translucency of the macerated material, the photographs cannot picture the place (adaxial or abaxial) of scale insertion. The numbering of scales corresponds with that on Fig.14 (organization of ovuliferous dwarf-shoots). The interrupted lines outline the underlying scales. a. After Plate XVI, 2, adaxial view. b. After Plate XVI, 4, adaxial view. c. After Plate XVII, 1, abaxial view. d. After Plate XVII, 2, adaxial view. e. After Plate XVI, 6a, adaxial view. f. After Plate XVI, $6 b$, adaxial view. (e and $f$ represent detached parts of a single fragment; the triangles mark place of detachment.) g. After Plate XVII, 3, abaxial view. h. After Plate XVI, 5, abaxial view.

Distal walls of encircling cells convex to straight.

On adaxial leaf surfaces epidermal cells often transversally rectangular. Anticlinal walls thickened, approximately $5 \mu \mathrm{m}$ wide. Epidermal papillae only observed on scales of ovuliferous dwarf-shoots, integuments and sometimes basally on distal parts of microsporophylls.

Hairs conical.

Exterior of cuticle showing a faint pattern of the cell walls. Cuticle approximately $10 \mu \mathrm{m}$ thick, measured halfway along an abaxial leaf surface.

Material and supplementary descriptions (Plates XII-XIX; Figs.1, 2, 6-8, 12-15, 17; Tables I-IV)

Material: The following material, all collected from Bletterbach localities (outside this region $O$. visscheri is so far unknown), was studied in detail: (1) several presumed penultimate and ultimate branches; (2) numerous leaves, originating from presumed main axes, penultimate and ultimate branches; (3) dispersed ovuliferous dwarf-shoots, sometimes with bracts and/or ovules; dispersed bracts, many dispersed seeds (only basal parts); (4) polliniferous cone fragments, consisting of a number of distal parts of 


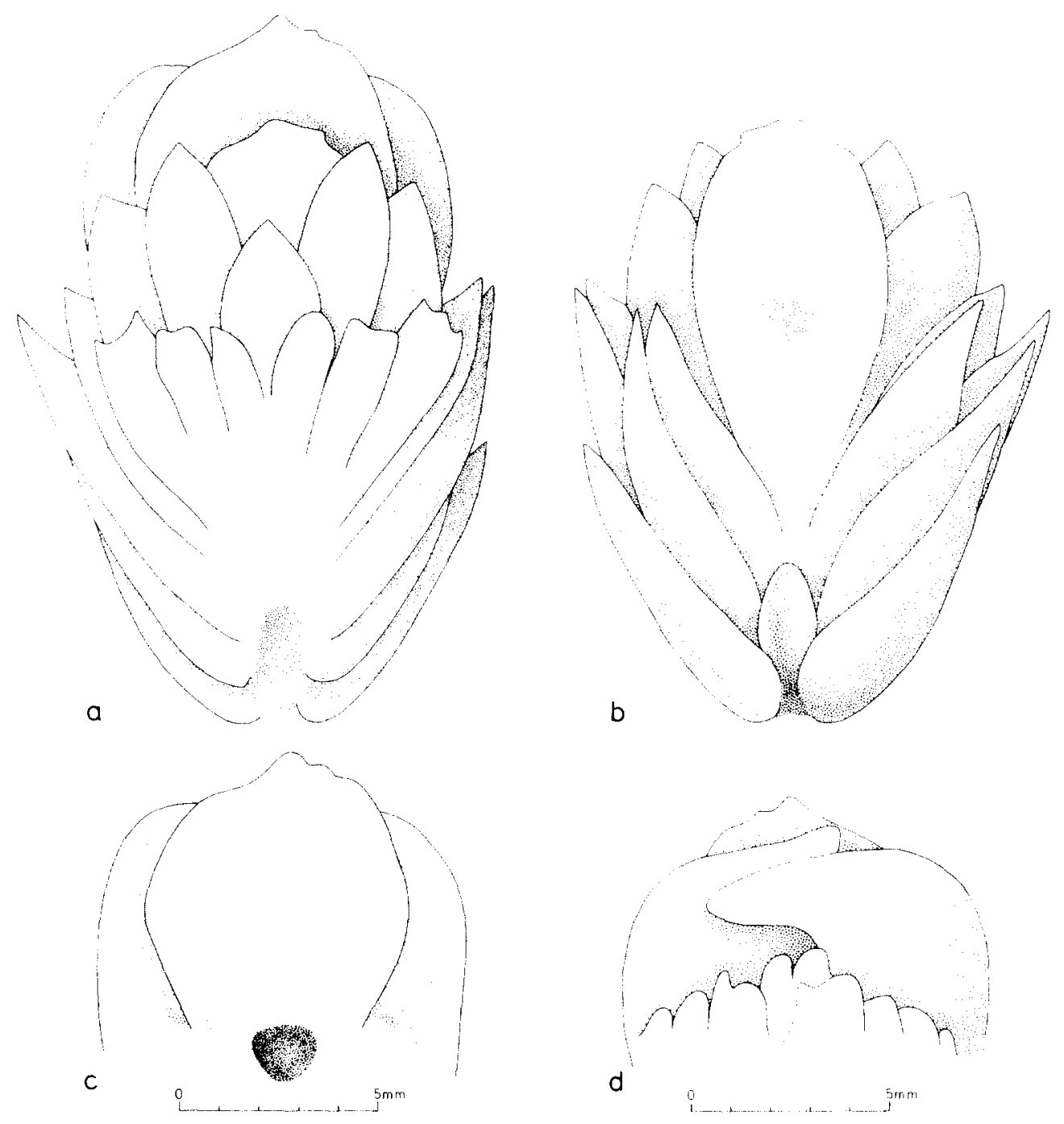

Fig.8. Reconstruction of ovuliferous dwarf-shoot and basal part of ovule of Ortiseia visscheri. a. Dwarf-shoot with ovule. b. Dwarf-shoot, ovule detached. c. Ovule (basal part) obverse view. $d$. Ovule (basal part) reverse view.

microsporophylls, dispersed distal parts of microsporophylls, dispersed pollen clusters.

Supplementary descriptions: Presumed leaves of main axes (Plate XII, 3-4; Fig.12): Leaves, only found dispersed, subtriangular, apex acute, up to $17 \mathrm{~mm}$ long, $11 \mathrm{~mm}$ wide.

Presumed penultimate branches (Plate XII, 1; Plate XIII; Plate XIV, 1-4; Fig.12): Longest fragment about $6 \mathrm{~cm}$. Axes 10-12 $\mathrm{mm}$ wide, axes 
together with leaves up to $20 \mathrm{~mm}$. Leaves arising at an angle of $30-45^{\circ}$, ovate, apex obtuse to acute; $9-15 \mathrm{~mm}$ long, 5-7 mm wide.

Presumed ultimate branches (Plate XII, 2; Plate XIV, 5-8; Plate XV, 1-2; Plate XIX; Fig.12): Longest fragment about $4 \mathrm{~cm}$. Axes 5-8 $\mathrm{mm}$ wide, axes together with leaves up to $12 \mathrm{~mm}$. Leaves arising at an angle of $\max$. $45^{\circ}$, ovate, apex obtuse to acute; $5-10 \mathrm{~mm}$ long, $3-4 \mathrm{~mm}$ wide.

Bracts (Plate XV, 3 and 4; Plate XVI, 1; Figs.12 and 13): 16-18 mm long, 7-10 $\mathrm{mm}$ wide.

Ovuliferous dwarf-shoots (Plate XVI, 2-6; Plate XVII, 1-5; Figs.7, 8, 13, 14): All specimens dispersed, up to $15.5 \mathrm{~mm}$ long, $11.5 \mathrm{~mm}$ wide. Size, shape and sequence (from basal to apical part of dwarf-shoot) of scales have been visualized in Fig.14; explanatory sketches after photographs are given in Fig.7; a reconstruction of the dwarf-shoot is shown in Fig.8.

Ovule/seed (Plate XVI, 3; Plate XVII, 6; Plate XVIII, 1; Figs.8, 13, 15): Specimens (only basal parts) isolated from dwarf-shoots about $8 \mathrm{~mm}$ wide; lateral differentiations $5 \mathrm{~mm}$ long, 3-4 mm wide; median differentiation $5 \mathrm{~mm}$ long, 7-8 $\mathrm{mm}$ wide. Dispersed specimens up to $13 \mathrm{~mm}$ wide, lateral strongly curved differentiations $10 \mathrm{~mm}$ long, $5 \mathrm{~mm}$ wide; median differentiation 7-8 $\mathrm{mm}$ long, 7-10 $\mathrm{mm}$ wide. Probable length $(18 \mathrm{~mm})$ deduced from the length of the dwarf-shoots.

Microsporophylls, distal parts (Plate XVIII, 2 and 3; Fig.12).

Prepollen (Plate XVIII, 4): Corresponding to the palynological formgenus Nuskoisporites Potonie et Klaus 1954; the prepollen will be described and discussed in a separate paper.

Epidermis of axes (Plate XIV, 1): For frequency of stomata, mean number of subsidiary cells per stomatal complex and frequency of hair bases see Table I.

Epidermis of leaves, bracts and distal parts of microsporophylls (for plate references see above-mentioned descriptions of the elements concerned; Fig.12): Stomata generally situated in parallel and/or converging rows. Orientation of stomata transversal or longitudinal, sometimes oblique.

Epidermis of scales of ovuliferous dwarf-shoots (Plate XVII, 5): Stomata often arranged in longitudinal rows.

Arrangement of stomata rather constant per individual element (leaves of presumed main axes, penultimate and ultimate branches, respectively; bracts, scales and distal parts of microsporophylls) see Table II.

For marginal stomata-free zones see Plate XII, 4b; Plate XV, 4; Fig.12. For apical stomata-free zones see Plate XVIII, 3; Fig.12. For median stomatafree zones see Plate XV, 4a; Plate XVIII, 2a and 3; Fig.12. For dimensions of stomata-free zones see Figs.1, 12; Table II. A detailed organization of the stomatal complex is reconstructed in Fig.2a; further see Plate XIV, 4; Plate XIX, 2.

Epidermal papillae, when present, about $8 \mu \mathrm{m}$ in diameter (see Plate XVII, 5).

Hair bases recognizable as two concentric circles; the smaller $(6 \mu \mathrm{m})$ situated on both sides of the cuticle, the larger $(20 \mu \mathrm{m})$ only on the exterior 
side (see Plate XV, 1; Plate XVI, 1; Plate XVIII, 2b; Plate XIX, 1a and 2b; Fig. 2b). Hair bases difficult to distinguish on leaves of presumed main axes and penultimate branches. Hairs about $50 \mu \mathrm{m}$ long (see Plate XVII, 4; Fig. 2b).

For frequency of stomata, mean number of subsidiary cells/stomatal complex, mean dimensions of epidermal cells, occurrence of papillae and frequency of hair bases, see Table III.

Ortiseia jonkeri nov. sp. (Plates XX-XXXI; Figs.9, 10, 12, 13, 15)

Holotype: Specimen 14108, Laboratory of Palaeobotany and Palynology of the State University of Utrecht, The Netherlands.

Locus typicus: Cortiana.

Stratum typicum: Val Gardena Formation.

Derivatio nominis: Dr. F.P. Jonker, Professor emeritus at the Laboratory of Palaeobotany and Palynology, Utrecht.

Diagnosis: Pinnately branched lateral shoot systems, consisting of a penultimate branch with two lateral series of parallel, more or less alternating ultimate branches, situated in one plane. Leaves not or hardly overlapping, arising at an angle of $30-80^{\circ}$, straight; shape narrow-subtriangular or lanceolate, apex acute, sometimes acuminate, curving upward; observed length 2.5-7 mm. Leaf base slightly contracted, with tendency to leaf-base cushion, approximately circular in section.

Ovuliferous cone at least $7 \mathrm{~cm}$ long, $2 \mathrm{~cm}$ wide. Cone axis bearing spirally arranged bracts, slightly overlapping; shape of bracts obovate, apex acuminate, up to $14 \mathrm{~mm}$ long.

Ovuliferous dwarf-shoots bilaterally symmetrical, up to $12 \mathrm{~mm}$ long, $11 \mathrm{~mm}$ wide, reaching apex of subtending bracts. Dwarf-shoots provided with 24-28 sterile scales and a single fertile scale, approximately centrally emerging on the adaxial side. Shape of sterile scales variable, ranging from lanceolate to obovate towards the apical part of the dwarf-shoot. Fertile scale rhomboid, with an obtuse, sometimes slightly bilobated apex, extending to a level either below, equal with, or most frequently, beyond the apices of the upper sterile scales.

Ovule/seed elliptical (seldom ovate) up to $13 \mathrm{~mm}$ long. Basal part of integument extending into two lateral horn-shaped differentiations and one median-obverse triangular differentiation, bordering the hilum; on the reverse side, opposite the hilum, occurs a transverse, doubled, often tripled seam of protrusions, about $1 \mathrm{~mm}$ high. Apical (micropylar) area obtuse. Nucellus ovate, free to its base; pollen/archegonial chamber present. Megaspore membrane cutinized.

Polliniferous cone cylindric or elliptic, up to $4 \mathrm{~cm}$ long, $13 \mathrm{~mm}$ wide. Cone axis bearing numerous, spirally arranged microsporophylls. Proximal part of microsporophyll arising at an angle of approximately $90^{\circ}$, length 2.5-5 mm, elliptical in section. Distal part rhomboid to subtriangular, up to $4 \mathrm{~mm}$ long, $4 \mathrm{~mm}$ wide, parallel to cone axis or slightly diverging. 


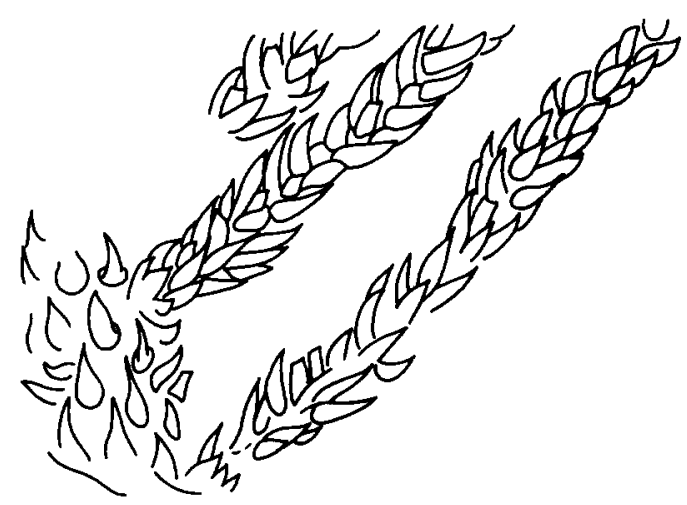

Fig.9. Explanatory sketch of shoot system of Ortiseia jonkeri, drawn after Plate XXI, 1.

Prepollen circular in polar view; mean diameter approximately $180 \mu \mathrm{m}$; mean width of monosaccoid differentiation $30 \mu \mathrm{m}$.

Basal part of bract non-stomatiferous for about $2 / 3$ of the abaxial surface; basal scales of ovuliferous dwarf-shoots (approximately thirteen scales), proximal part of microsporophylls and integument non-stomatiferous.

Stomata generally arranged in rows, which are seldom doubled (and then only on adaxial leaf surfaces). Adjacent stomatal complexes occurring, sometimes sharing an encircling cell, rarely a subsidiary cell. Mean distance of stomatal rows, measured halfway along a single abaxial surface varying between 140 and $300 \mu \mathrm{m}$ (5-12 epidermal cells); on adaxial surfaces between 140 and $200 \mu \mathrm{m}$ (6-8 epidermal cells), median stomata-free zone excluded. Frequency of stomata on adaxial surface slightly higher than on abaxial surface.

Marginal stomata-free zones rather narrow on leaves $(125-225 \mu \mathrm{m})$, wider on bracts and distal parts of microsporophylls $(0.75-2 \mathrm{~mm})$. Apical stomata-free zones always present on abaxial surfaces $(0.25-2 \mathrm{~mm}$ long); on adaxial surfaces stomatal rows ending near apex. Median stomata-free zones on abaxial surfaces extending over $3 / 4$ to $1 / 2$ of the surface, reckoned from the apex; on adaxial surfaces present from the basis onward. On bracts median stomata-free zones not always clearly recognizable.

Stomatal complexes mostly dicyclic, sometimes monocyclic to incomplete dicyclic on leaf bases. Guard cells sunken; proximal walls of subsidiary cells forming a mostly bulging rim, often bearing solid papillae; distal walls slightly convex to straight. Mean number of subsidiary cells per stomatal complex, measured on a single surface, rather constant (6.3-6.6).

Distal walls of encircling cells slightly convex to straight.

Anticlinal walls approximately $3 \mu \mathrm{m}$ wide. Epidermal papillae regularly occurring on leaves, bracts, distal parts of microsporophylls, upper scales of ovuliferous dwarf-shoots and integuments; papillae apparently absent on main axes and axes of penultimate branches.

Hairs conical. 


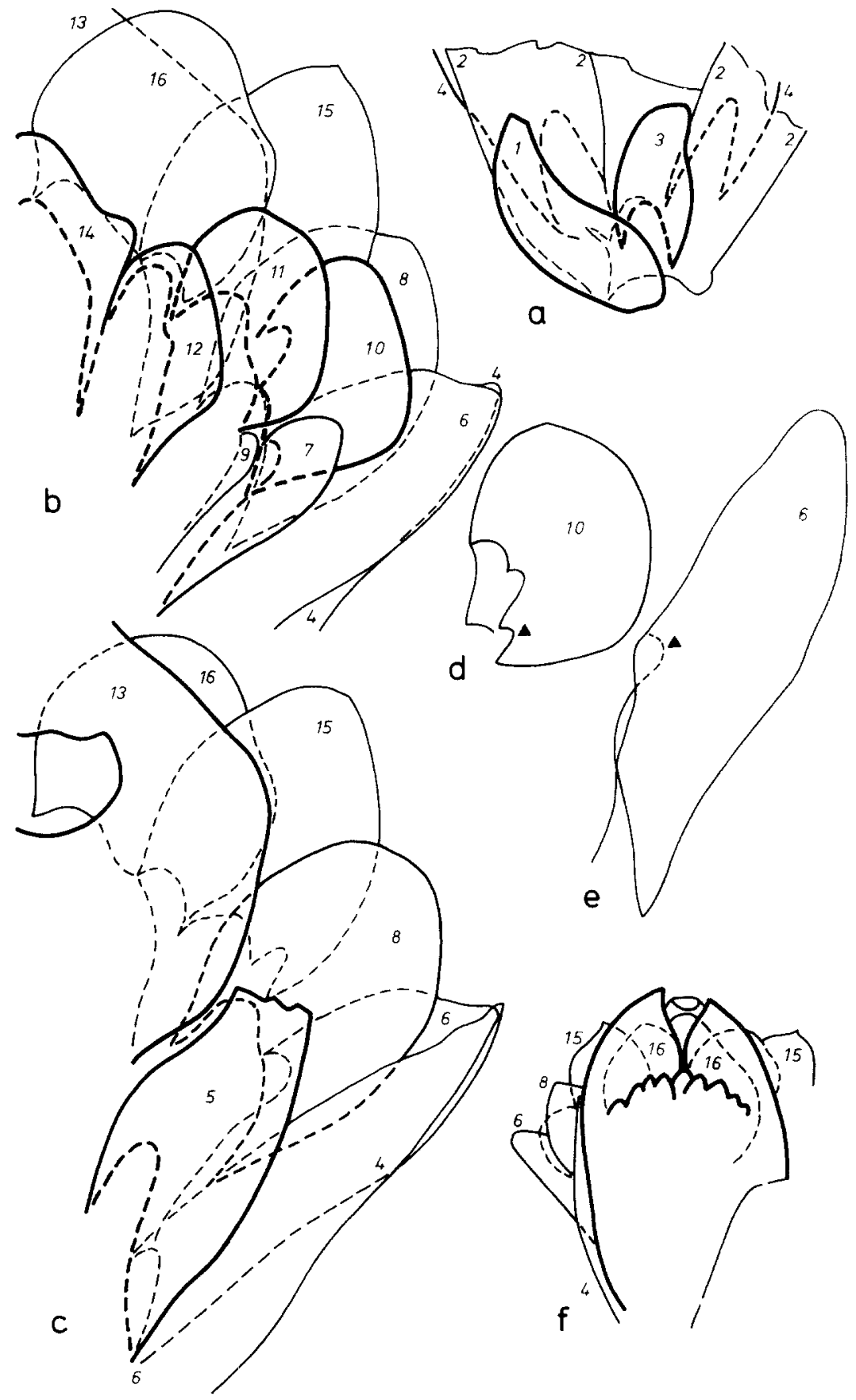

Fig. $10 a-f$. 


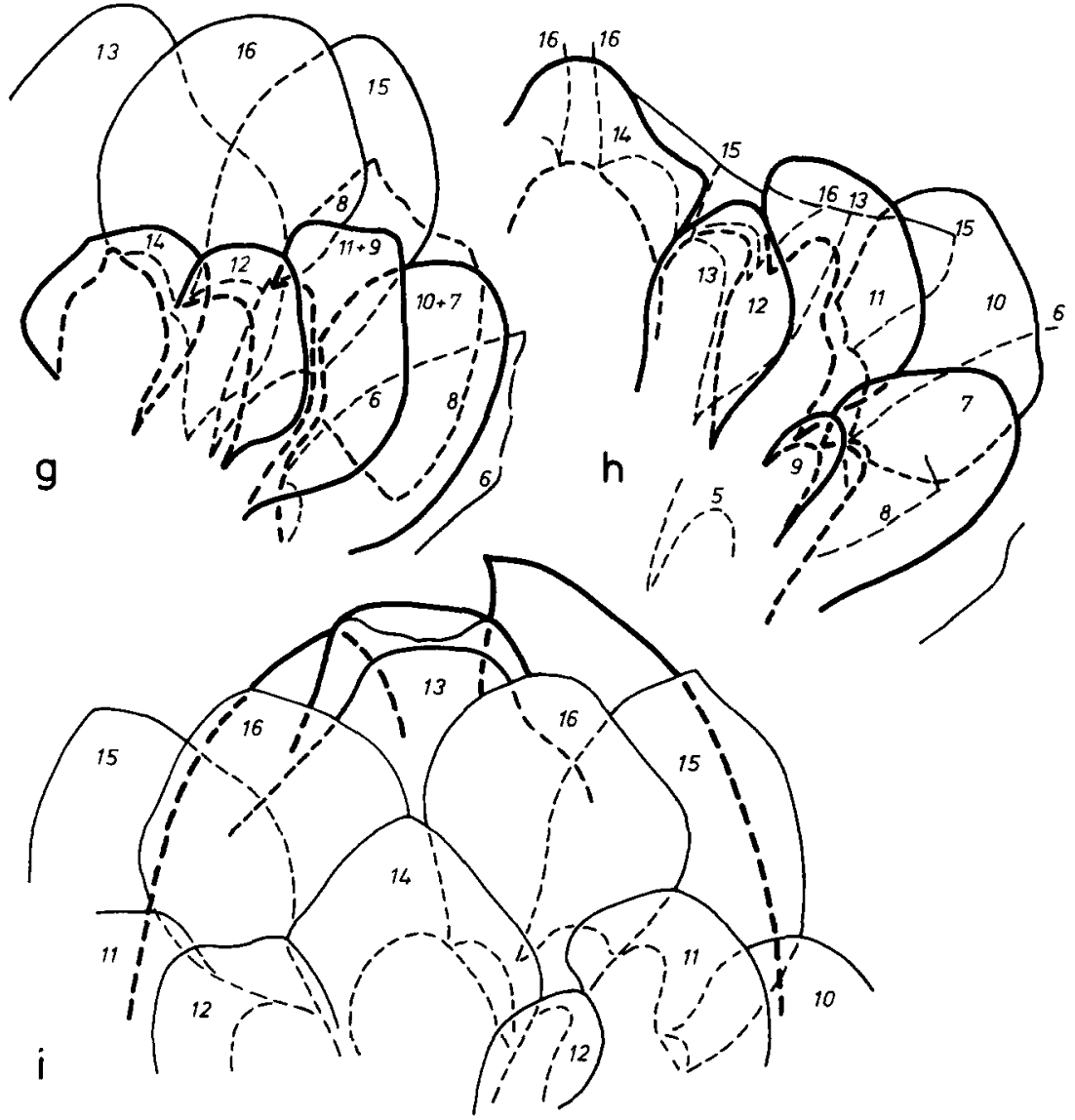

Fig.10. Explanatory sketches, drawn after photographs of (fragments of) ovuliferous dwarf-shoots, belonging to Ortiseia jonkeri. Because of the translucency of the macerated material the photographs cannot picture the place (adaxial or abaxial) of scale insertion. The numbering of scales corresponds with that on Fig.14 (organization of ovuliferous dwarf-shoots). The interrupted lines outline the underlying scales. a. After Plate XXV, 6, adaxial view. b. After Plate XXVI, 3, left, drawn in reverse, abaxial view. c. After Plate XXVI, 3, right, adaxial view. d. After Plate XXVI, 1a, adaxial view. e. After Plate XXVI, $1 \mathrm{~d}$, adaxial view. ( $\mathrm{d}$ and $\mathrm{e}$ represent detached scales of a single fragment; the triangles mark the place of detachment). f. After Plate XXV, 5, dwarf-shoot with ovule, adaxial view. g. After Plate XXVIII, 1a, abaxial view, mind absence of scales 7 and 9, scales 10 and 11 more strongly developed (compare with $b$ and $h$; both types of dwarf-shoots occur in a single cone). h. After Plate XXVIII, $1 \mathrm{~b}$, abaxial view. i. After Plate XXVII, 2, abaxial view, same specimen as $f$.

Exterior of cuticle without cellular pattern, showing disorderly structure. Cuticle approximately $5 \mu \mathrm{m}$ thick, measured halfway along an abaxial leaf surface.

Material and supplementary descriptions (Plates XX-XXXI; Figs.1, 2, 9-15, 17; Tables I-VI) 


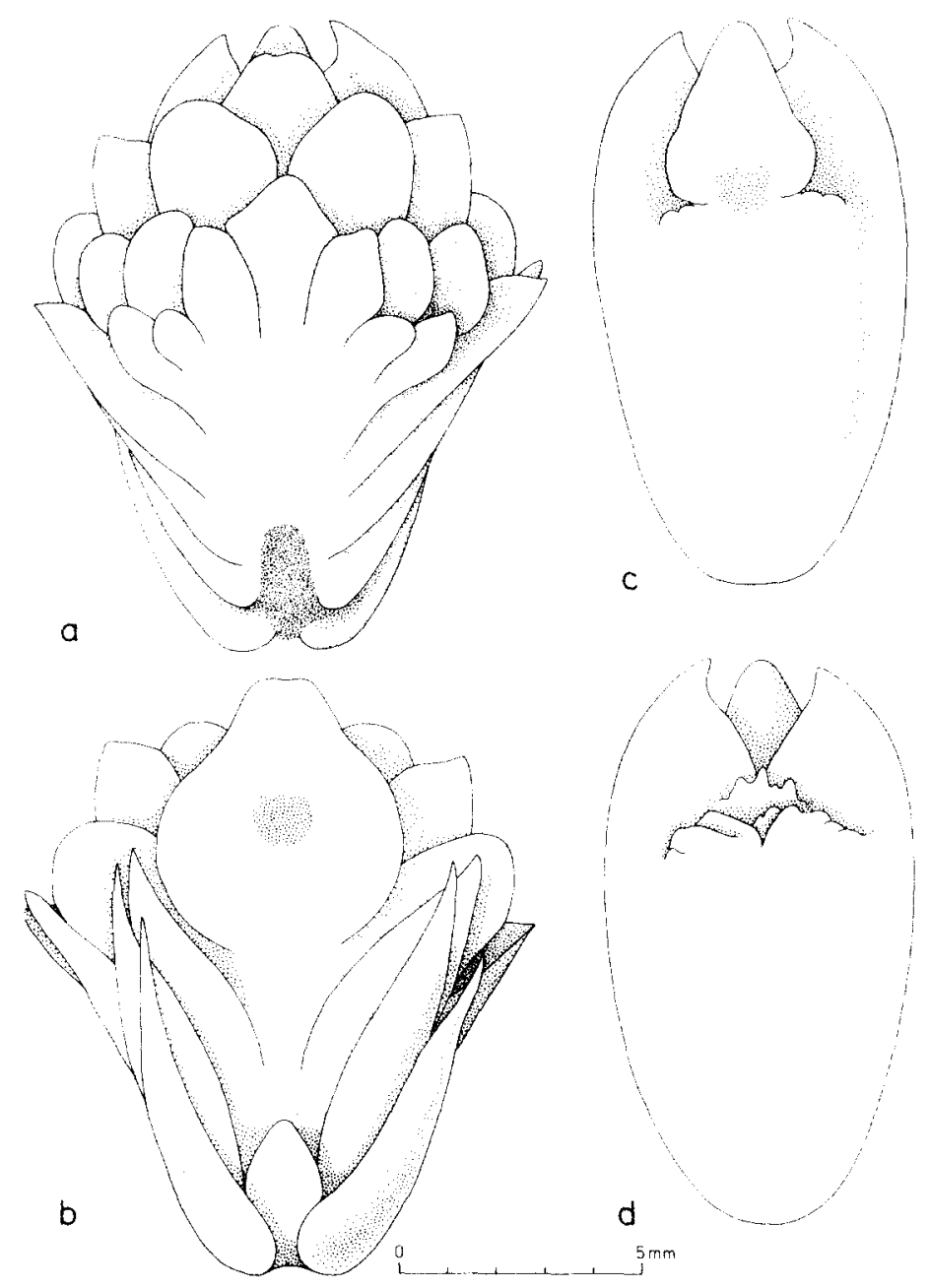

Fig.11. Reconstruction of ovuliferous dwarf-shoot and ovule of Ortiseia jonkeri. a. Dwarfshoot with ovule, abaxial view. b. Dwarf-shoot, ovule detached, adaxial view. c. Ovule, obverse view. d. Ovule, reverse view.

Material: The following material, collected from various localities (see Table IV) was studied in detail: (1) a single fragment of a presumed leafy main axis; (2) several lateral shoot-systems; (3) some penultimate branches, many ultimate branches; (4) numerous dispersed leaves, originating from presumed main axes, penultimate and ultimate branches; (5) two detached ovuliferous cones, one cone-fragment, several dispersed ovuliferous dwarfshoots, bracts and (rarely) seeds; and (6) five detached polliniferous cones; some small cone fragments; numerous dispersed distal parts of microsporophylls. 


\section{TABLE IV}

Survey of the vegetative and fertile Ortiseia remains, collected in the Dolomites and the Vicentinian Alps $[(+)=$ small $;+=$ average $;++=$ large quantity $; c=$ cone $]$

\begin{tabular}{|c|c|c|c|c|c|c|c|c|c|}
\hline \multirow[t]{3}{*}{ Locality } & \multicolumn{3}{|c|}{ O. leonardii } & \multicolumn{3}{|c|}{ O. visscheri } & \multicolumn{3}{|c|}{ O. jonkeri } \\
\hline & \multirow[t]{2}{*}{ veg. } & \multicolumn{2}{|c|}{ fert. } & \multirow[t]{2}{*}{ veg. } & \multicolumn{2}{|c|}{ fert. } & \multirow[t]{2}{*}{ veg. } & \multicolumn{2}{|l|}{ fert. } \\
\hline & & 8 & 6 & & ९ & $\delta$ & & q & $\delta$ \\
\hline \multicolumn{10}{|l|}{ DOLOMITES } \\
\hline \multicolumn{10}{|l|}{ Redagno-Butterloch } \\
\hline R1 & + & + & - & + & - & - & + & - & - \\
\hline $\mathrm{R} 2$ & + & $+c$ & - & + & + & - & $(+)$ & - & - \\
\hline R 3a & + & - & - & $(+)$ & - & - & ++ & + & - \\
\hline R3b & + & - & - & + & - & - & + & $+c s$ & - \\
\hline R4 & ++ & $+c$ & $+c s$ & + & + & - & + & + & $+c s$ \\
\hline R5-73 & + & - & - & + & + & - & + & - & + \\
\hline R5-74 & + & + & - & - & - & - & + & - & - \\
\hline \multicolumn{10}{|l|}{ Redagno-Taubenleck } \\
\hline RTA & + & + & - & ++ & ++ & + & - & - & - \\
\hline RTB & + & - & - & + & + & - & - & - & - \\
\hline RTD & + & + & - & + & + & + & + & - & $+c$ \\
\hline RTD1 & + & - & - & - & - & - & + & - & - \\
\hline RTD2 & + & - & - & + & + & + & + & - & - \\
\hline RTD3 & + & - & - & - & - & - & ++ & - & + \\
\hline RTD4 & + & - & - & - & - & - & - & - & - \\
\hline RTD5 & + & - & $+c$ & + & - & - & - & - & - \\
\hline Val Gardena-Seceda & ++ & $+c$ & - & - & - & - & $(+)$ & - & - \\
\hline Val Gardena-Roncadizza & + & - & - & - & - & - & - & - & - \\
\hline \multicolumn{10}{|l|}{ VICENTINIAN ALPS } \\
\hline Ulbe D & $(+)$ & - & - & - & - & - & $(+)$ & - & - \\
\hline Ulbe $\bar{Z}$ & - & - & - & - & - & - & ++ & - & $+\mathbf{c}$ \\
\hline Scocchi & + & $+\mathbf{c}$ & - & - & - & - & - & - & - \\
\hline Cortiana & $(+)$ & - & - & - & - & - & ++ & $+c$ & - \\
\hline Casarotti & $(+)$ & - & - & - & - & - & - & - & - \\
\hline
\end{tabular}

Supplementary descriptions: Presumed main axis (Plate XXI, 3-6; Fig.12): Length $7 \mathrm{~cm}$, width $2 \mathrm{~cm}$, surface showing folds (Plate XXI, 5). Leaves arising at a small angle, straight, narrow-subtriangular, apex acute; about $7 \mathrm{~mm}$ long, $4-5 \mathrm{~mm}$ wide.

Lateral shoot systems (Plate XX; Plate XXI, 1; Fig.9).

Penultimate branches (Plate XX; Plate XXI, 1 and 7; Plate XXII, 1-3; Figs.9 and 12): Longest fragment $14 \mathrm{~cm}$. Axes $3-5 \mathrm{~mm}$ wide, axes together with leaves up to $7 \mathrm{~mm}$; surface showing folds (Plate XXI, 7; Plate XXII, 1). Leaves arising at an angle of $30-45^{\circ}$, straight, narrow-subtriangular, apex acute and curving upward; about $5 \mathrm{~mm}$ long, $3 \mathrm{~mm}$ wide. Adaxial leaf base often shows bulbous protrusions (Plate XXII, 1-2; Fig.12).

Ultimate branches (Plate XX; Plate XXI, 1; Plate XXII, 4-6; Plate XXIII; 
Plate XXIV, 1; Plate XXIX, 1-2; Figs.9, 12): Arranged at an angle of $45-60^{\circ}$ on the penultimate branch with interspaces of $4-7 \mathrm{~mm}$. Observed length max. $12 \mathrm{~cm}$. Axes $1-2 \mathrm{~mm}$ wide, axes together with leaves up to $4 \mathrm{~mm}$. Leaves arising at an angle of $45-80^{\circ}$, straight, narrow-subtriangular to lanceolate, apex acute, acuminate and curving upward; $2.5-5 \mathrm{~mm}$ long, $1-1.5 \mathrm{~mm}$ wide. Clear tendency to leaf-base cushion.

Ovuliferous cones approximately $7 \mathrm{~cm}$ long, $2-3 \mathrm{~cm}$ wide. Observed width cone axis $7 \mathrm{~mm}$.

Bracts (Plate XXIV, 2-4; Plate XXV, 1; Figs.12-13): Up to $14 \mathrm{~mm}$ long, 8-10 $\mathrm{mm}$ wide.

Ovuliferous dwarf-shoots (Plate XXV, 2-8; Plate XXVI; Plate XXVII; Plate XXVIII, 1-3; Plate XXXI, 4; Figs.10, 11, 13, 14, 16): Specimens, isolated from cones and dispersed ones $11-13 \mathrm{~mm}$ long, up to $11 \mathrm{~mm}$ wide. Size, shape and sequence (from basal to apical part of dwarf-shoot) of scales have been visualized in Fig.14; explanatory sketches after photographs are given in Fig.10; a reconstruction of the dwarf-shoot is shown in Fig.11.

Ovules/seeds (Plate XXV, 2, 4, 5; Plate XXVII, 2; Plate XXVIII, 4-5; Plate XXIX, 1-3; Figs. 10, 11, 13, 15-17): Specimens isolated from cones 7-12 mm long, 5-7 mm wide; lateral differentiations $3 \mathrm{~mm}$ long, $2 \mathrm{~mm}$ wide, median differentiation $3 \mathrm{~mm}$ long, $3 \mathrm{~mm}$ wide. Dispersed specimens up to $13 \mathrm{~mm}$ long, $9 \mathrm{~mm}$ wide; lateral differentiations $6 \mathrm{~mm}$ long, $4 \mathrm{~mm}$ wide, median differentiation $4 \mathrm{~mm}$ long, $4 \mathrm{~mm}$ wide.

Polliniferous cones (Plate XXI, 2; Plate XXX, 1): Length 2-4 cm, width 7-13 mm. Situation and number of pollen-sacs so far unknown. Cone axis 2-3 mm wide. Microsporophylls, distal parts (Plate XXIX, 4 and 5; Plate XXX, 1-3; Plate XXXI, 3; Fig.12): 3-4 mm long, 3-4 mm wide.

Prepollen (Plate XXX, 4): Corresponding to the palynological form-genus Nuskoisporites Potonié et Klaus 1954; the prepollen will be described and discussed in a separate paper.

Epidermis of axes: For frequency of stomata, mean number of subsidiary cells per stomatal complex, occurrence of papillae and frequency of hair bases see Table I.

Epidermis of leaves, bracts and distal parts of microsporophylls (for plate-references see above-mentioned descriptions of the elements concerned; Fig.12): Stomata generally arranged in parallel and/or converging rows. On distal parts of microsporophylls stomata can be arranged in two groups on both sides of the median stomata-free zone (Plate XXIX, 5). Orientation of stomata transversal or longitudinal, sometimes oblique.

Epidermis of scales of ovuliferous dwarf-shoots (Plate XXVII, 5): Stomata generally arranged in short rows.

Arrangement of stomata rather constant per individual element (leaves of presumed main axes, penultimate and ultimate branches respectively; bracts, scales and distal parts of microsporophylls), see Table II.

For marginal stomata-free zones see Plate XXIV, 2a, 3; Plate XXX, 3; Fig.12. For apical stomata-free zones see Plate XXI, 4; Plate XXX, 3a; Fig.12. For median stomata-free zones see Plate XXI, 4 and 6; Plate XXII, 3a; 

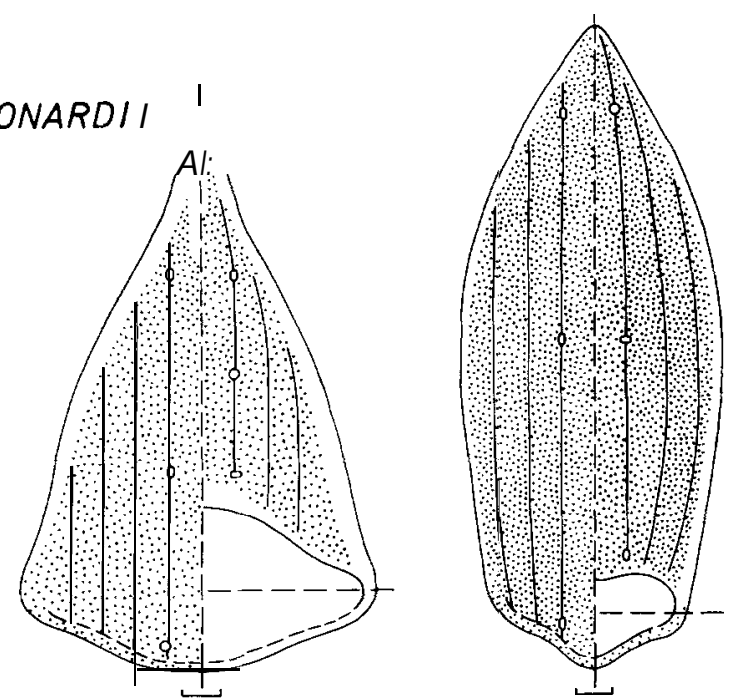

O. VISSCHERI
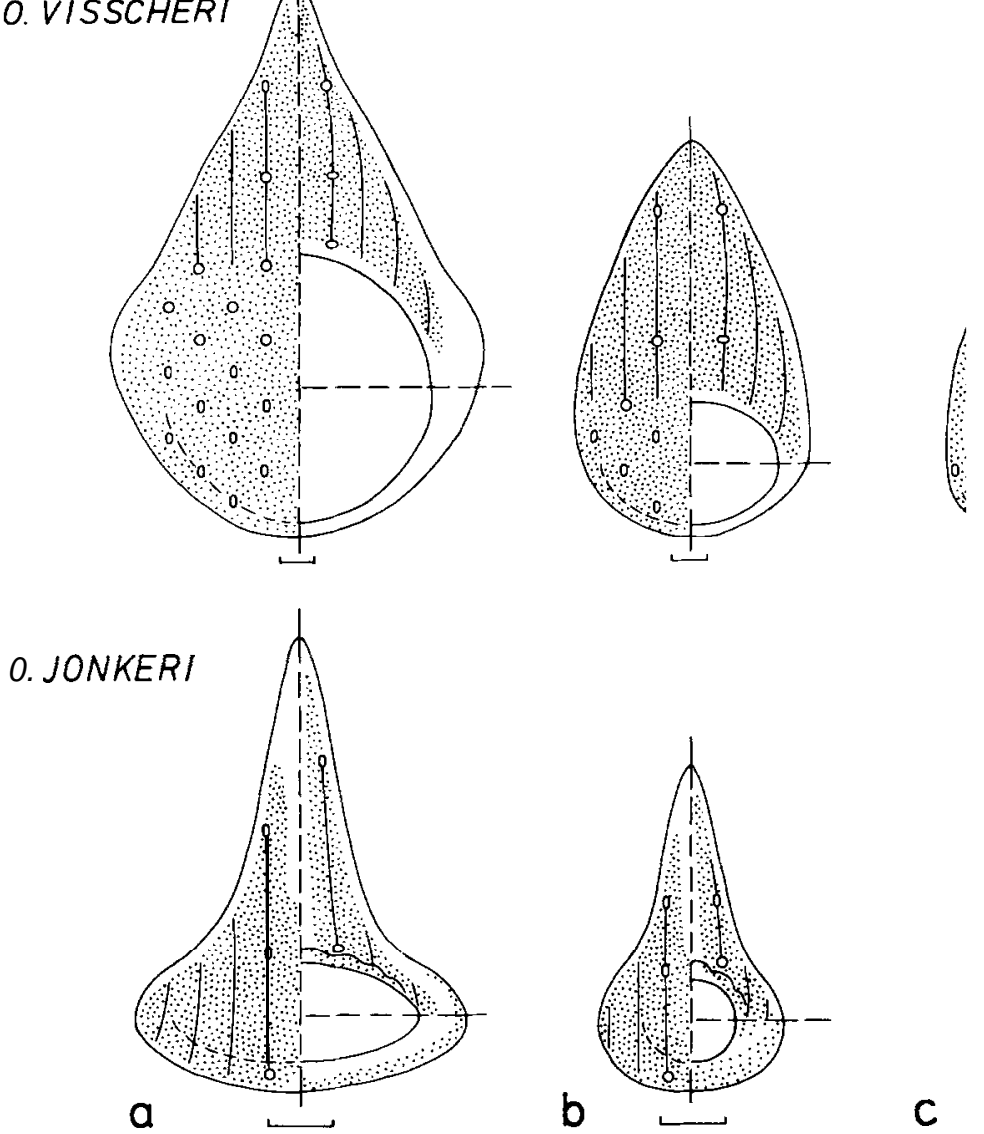

b

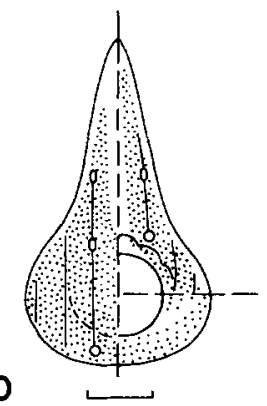

C

Fig. 12. Comparative scheme of leaves (originating from main, penul microsporophylls of 0 rtiseia leonardii, 0 . visscheri and 0 . jonkeri. situation of stomata. Left half of drawings represent abaxial surface, । areas represent stomatiferous areas, whereas white areas are stomata-fr of these lines does not correspond with number of stomatal rows). ( longitudinally orientated) and ellipses (stomata longitudinally or trar axes. c. Leaves ultimate axes. d. Bracts. e. D istal part of microsporoph 
pp. $85-86$.
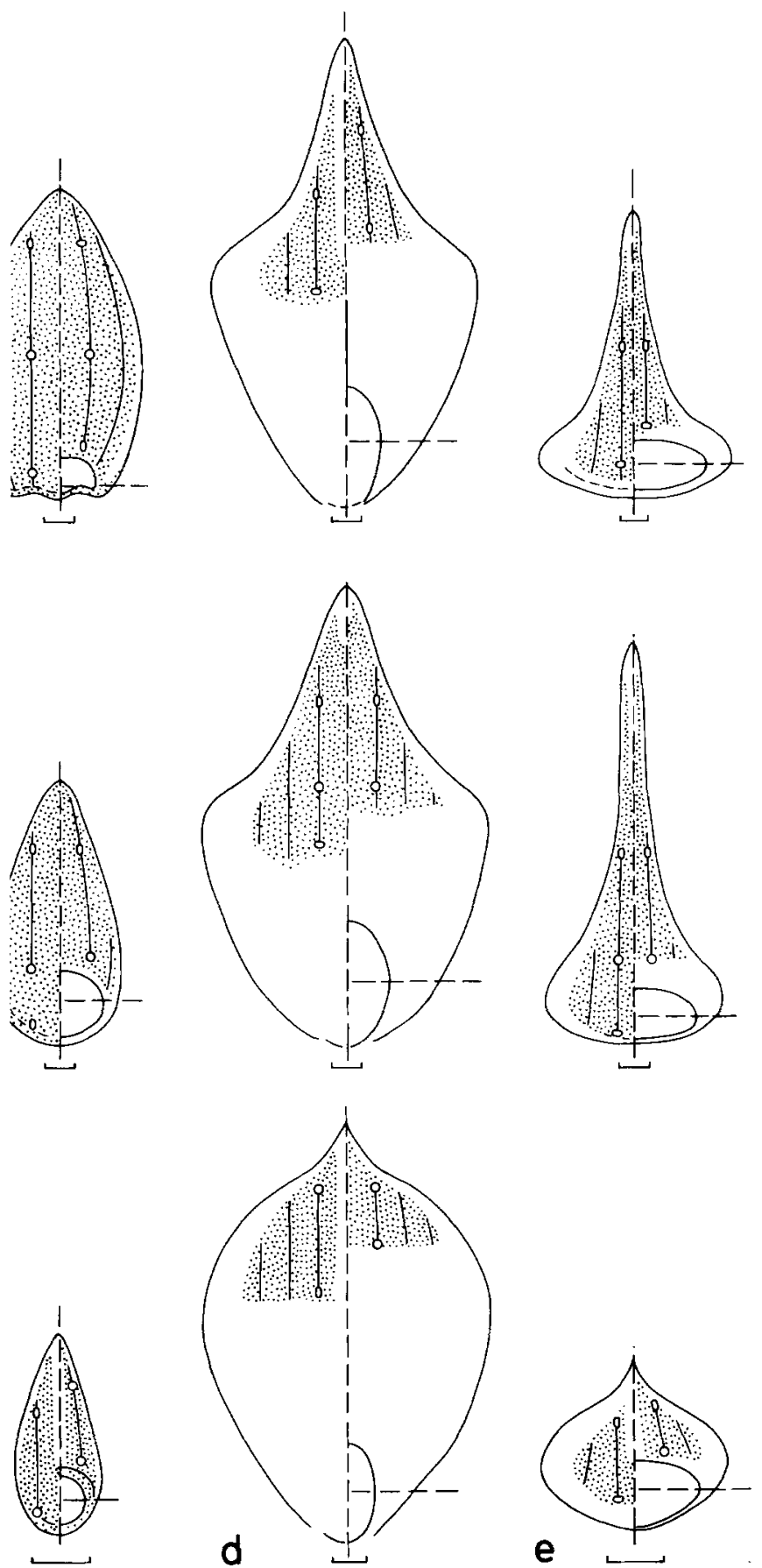

(timate and ultimate axes, respectively), bracts and distal parts of Compared are size and shape of the elements and orientation and right half, above horizontal interrupted line, adaxial surface. Dotted ree. Vertical lines indicate direction of stomatal rows (N.B. : number Orientation of stomata indicated by circles (stomata obliquely to nsversally orientated). a. Leaves main axes. b. Leaves penultimate yylls. 
pp. 87-88.

0. LEONARD/I
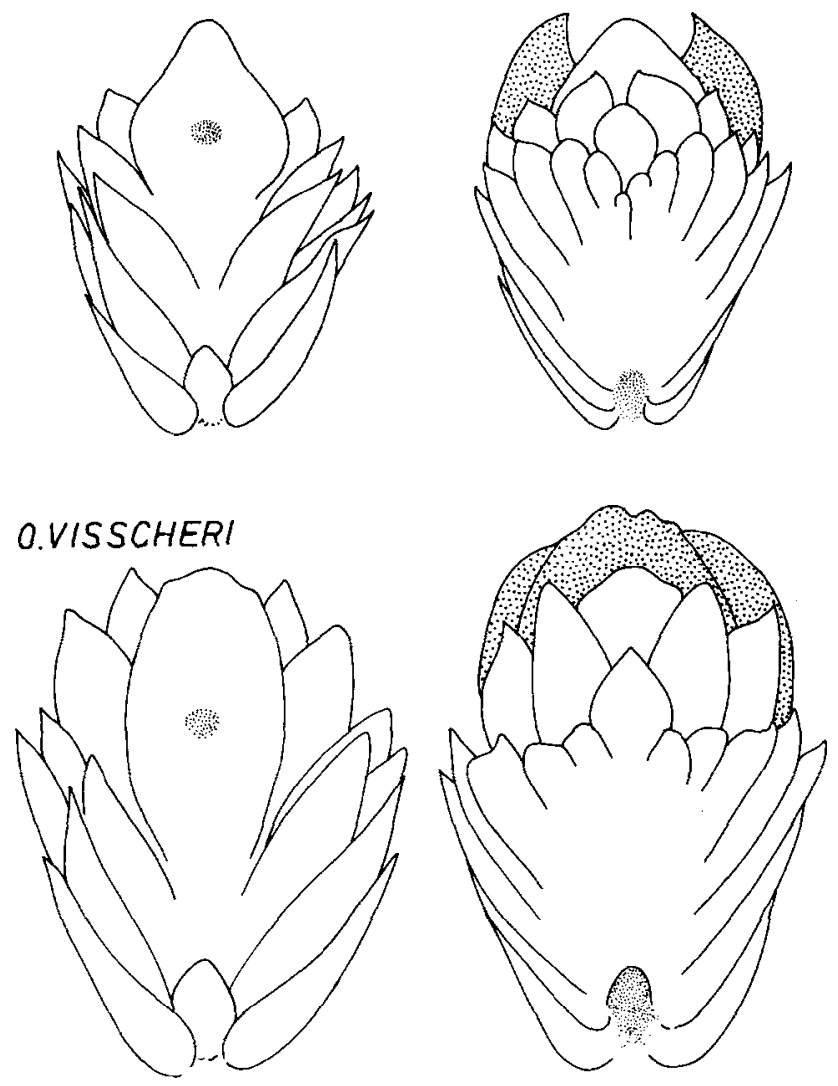

\section{O. JONKERI}

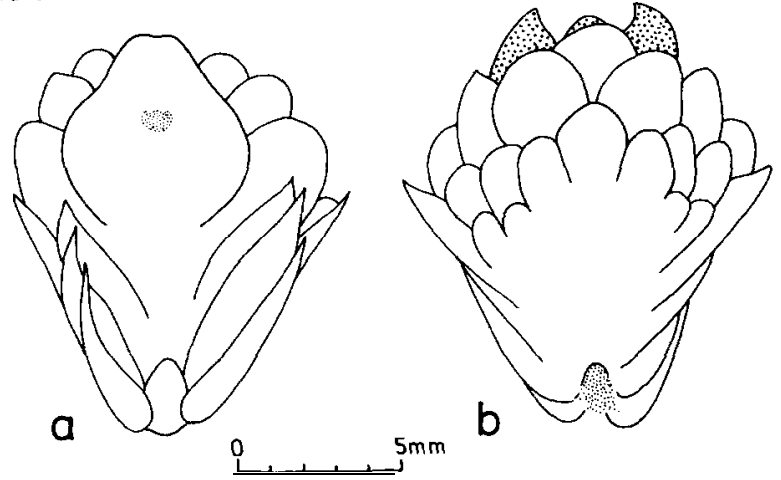

Fig.13. Comparative scheme of ovuliferous dwarf-shoots, ovu bract hatched. a. Ovuliferous dwarf-shoots, adaxial view, ov reverse view. d. Bract, ovuliferous dwarf-shoot, ovule, abaxial 

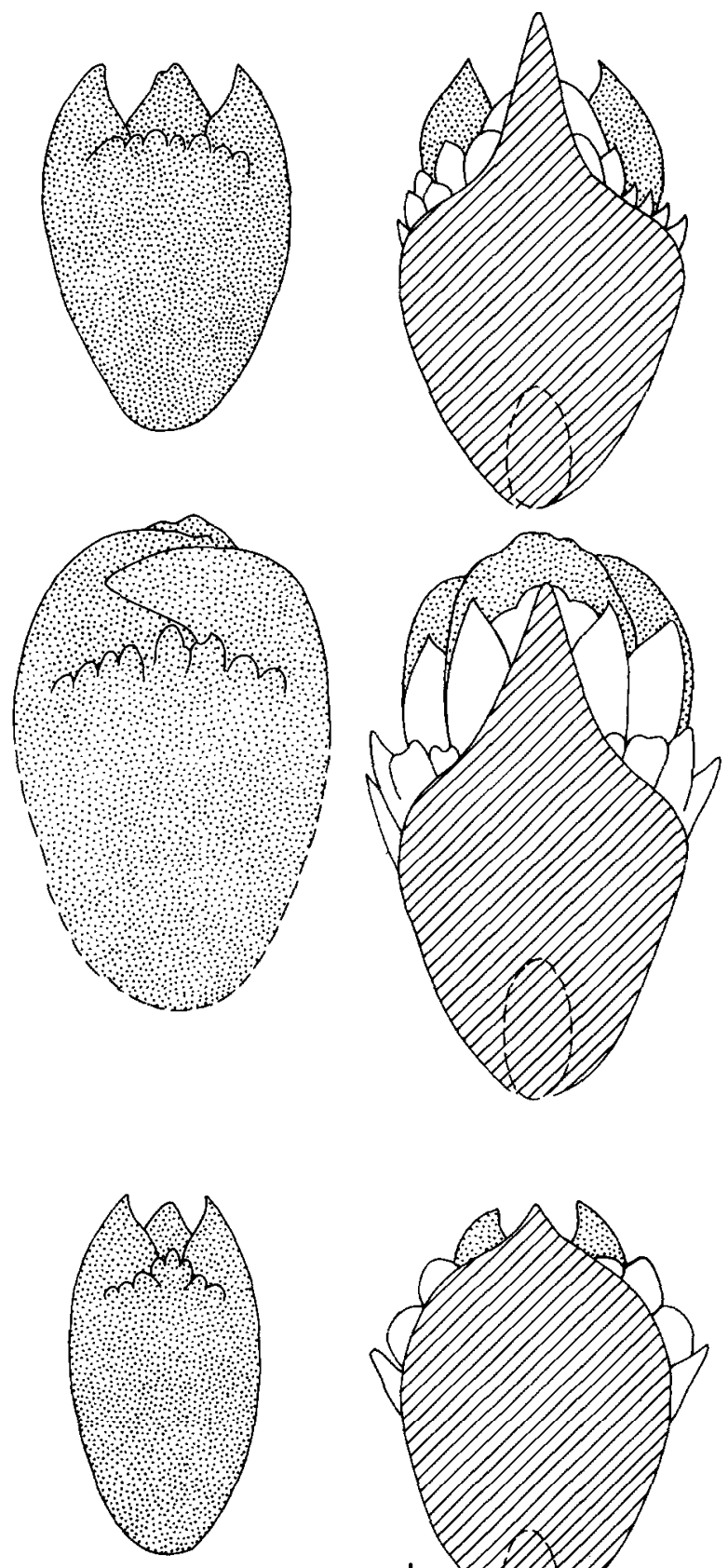

c

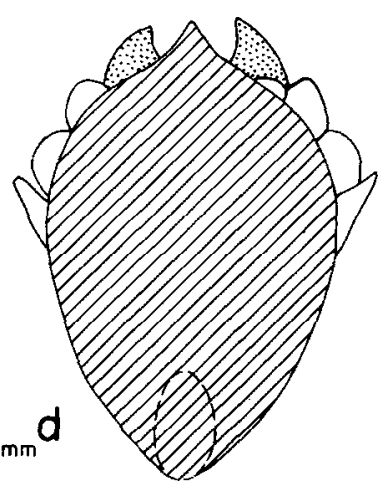

rules and bracts of Ortiseialeonardii, 0 . visscheri and 0. jonkeri. Ovule dotted, vule detached. b. Ovuliferous dwarf-shoot with ovule, abaxial view. c. Ovule, al view. 


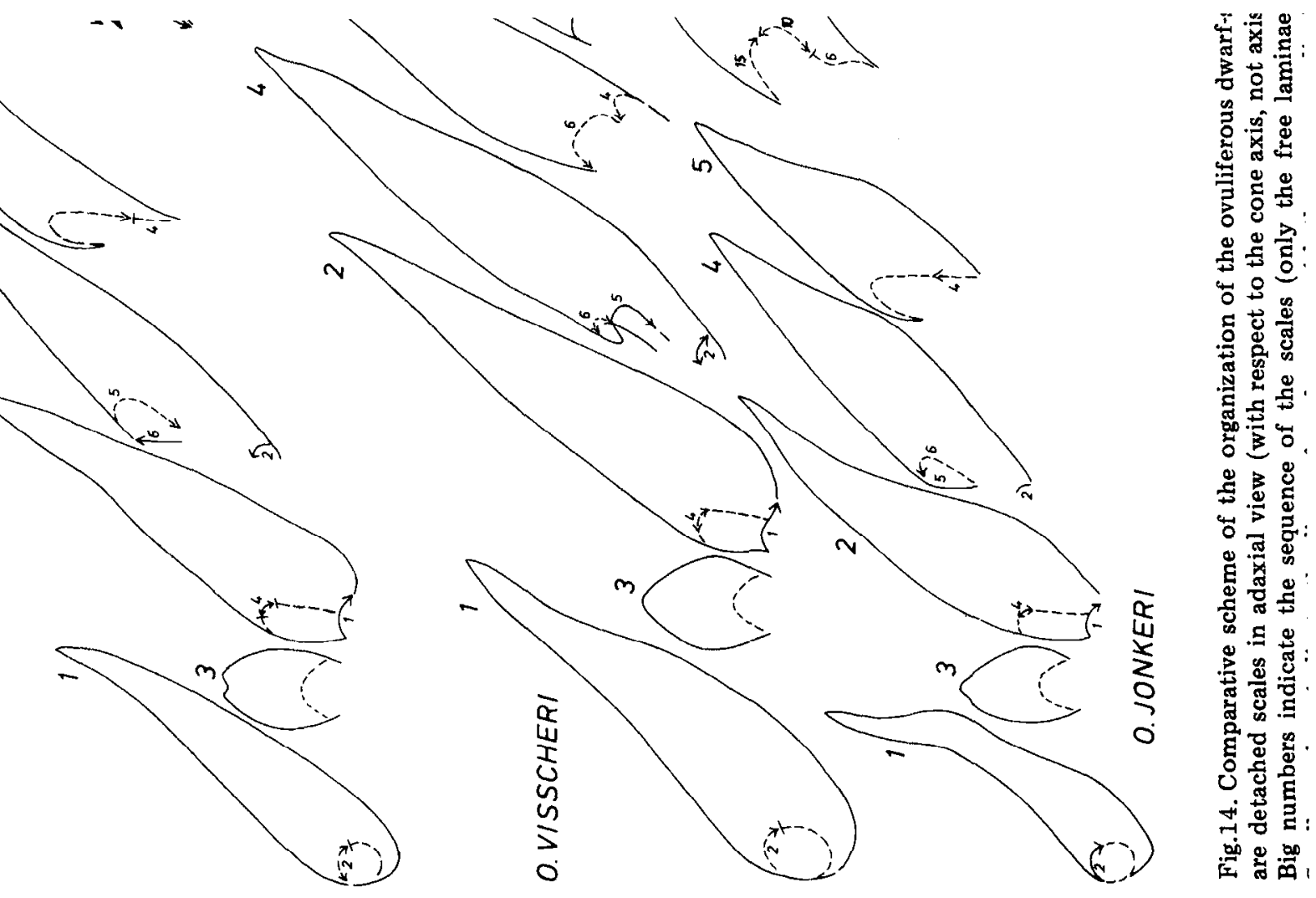



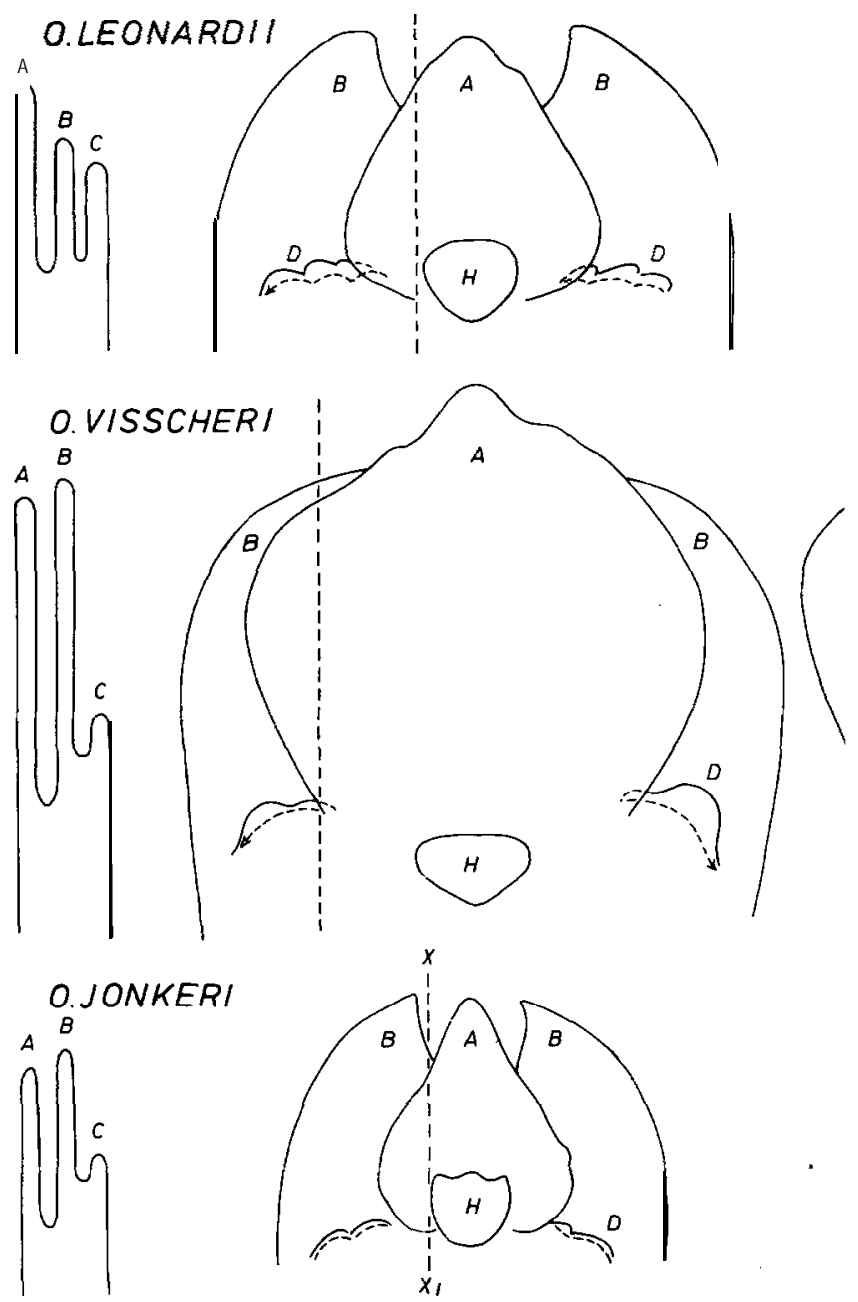

Fig.15. Comparative scheme of the integumentary extensic integumentary extension; $\mathbf{B}=$ lateral integumentary exten hilum; $\mathbf{X}-\mathbf{X I}=$ longitudinal section, obverse to reverse; $\mathbf{Y}-$ lower case letters indicate borders with other extensions (cor 

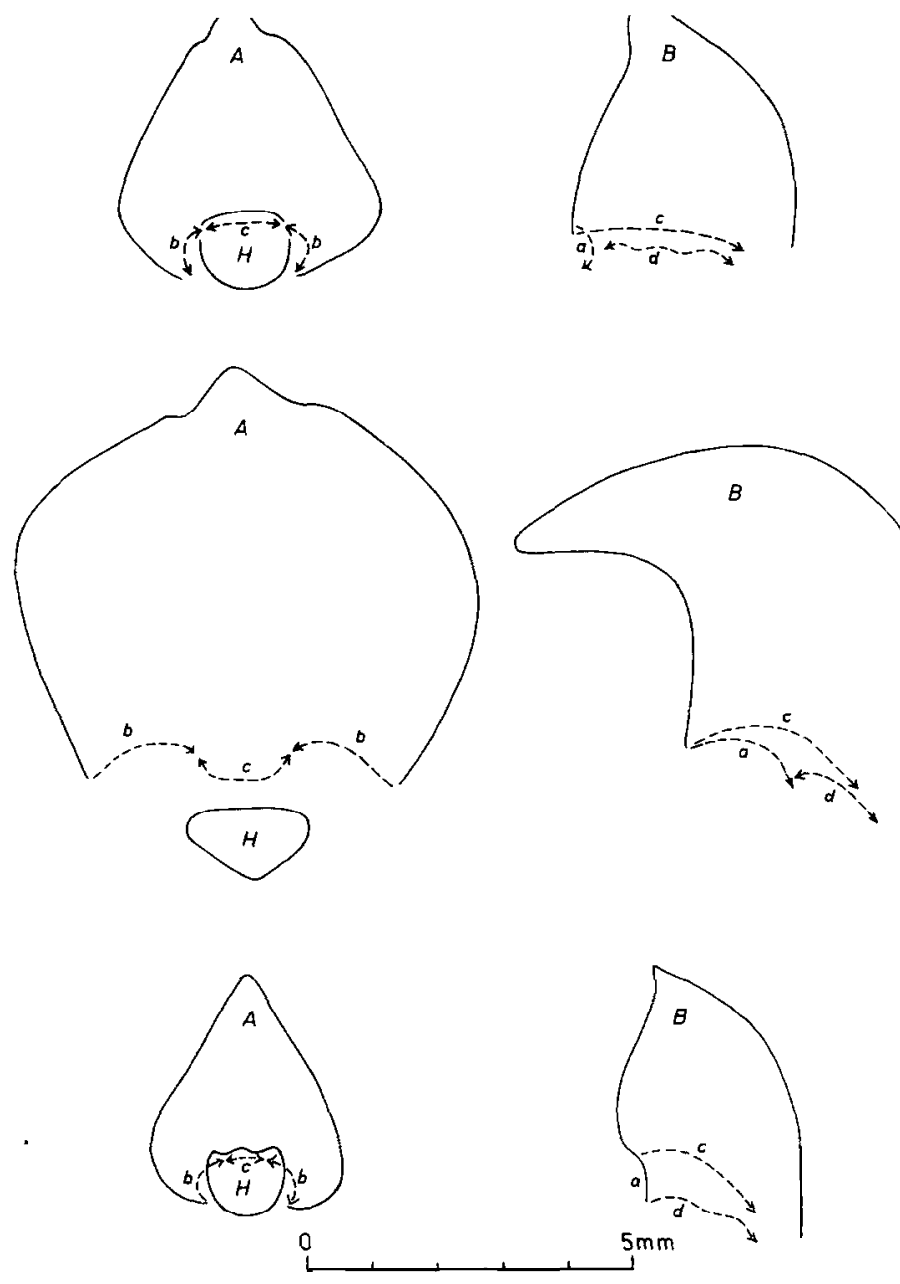

nsions of ovules of Ortiseia leonardii, 0 . visscheri and 0 . jonkeri. tension; $C=$ protrusions on reverse side; $D=$ protrusions on obvers $Y-Y 1=$ longitudinal median section, reverse to obverse. Interrupte 'correspondingly marked with capitals). 

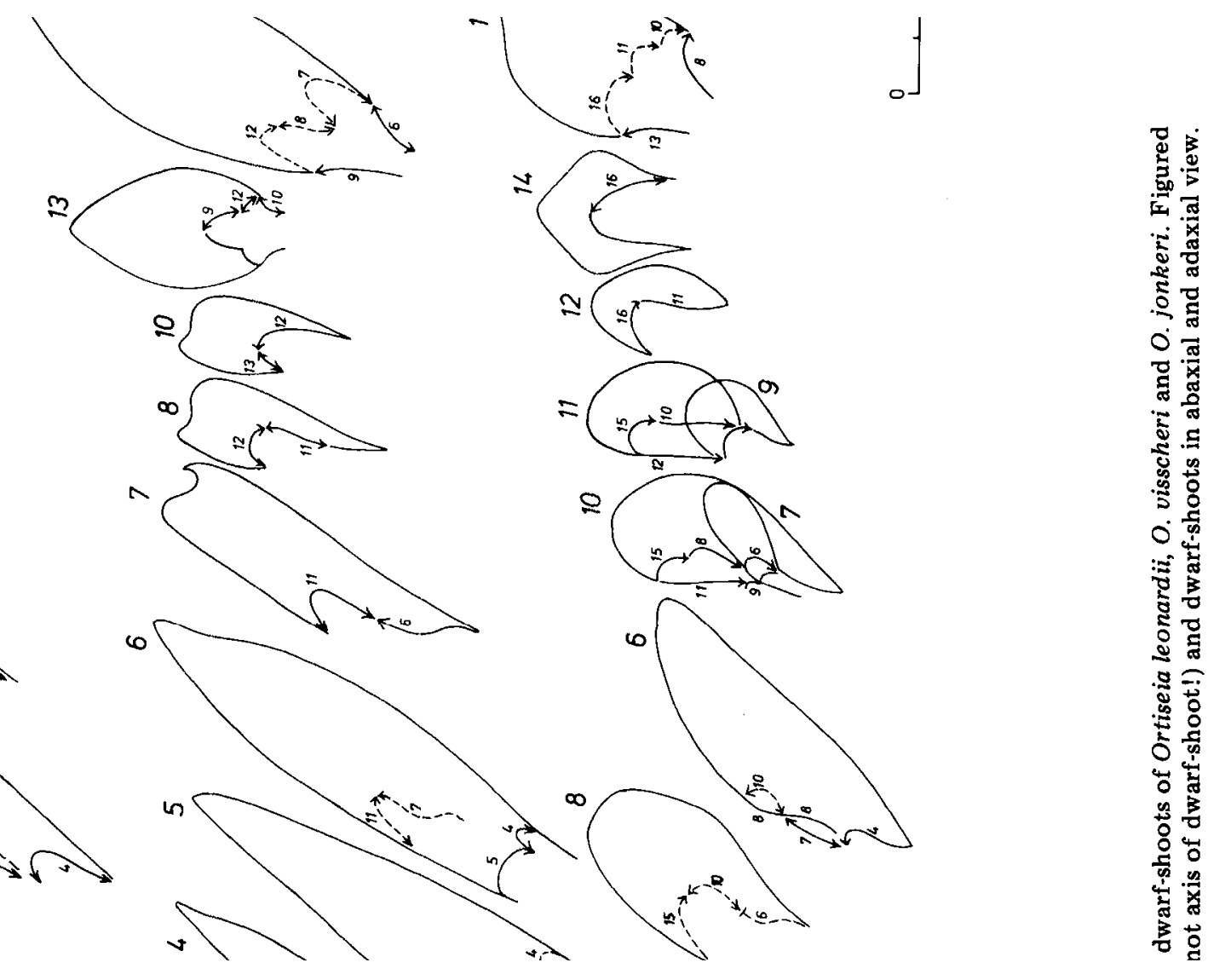

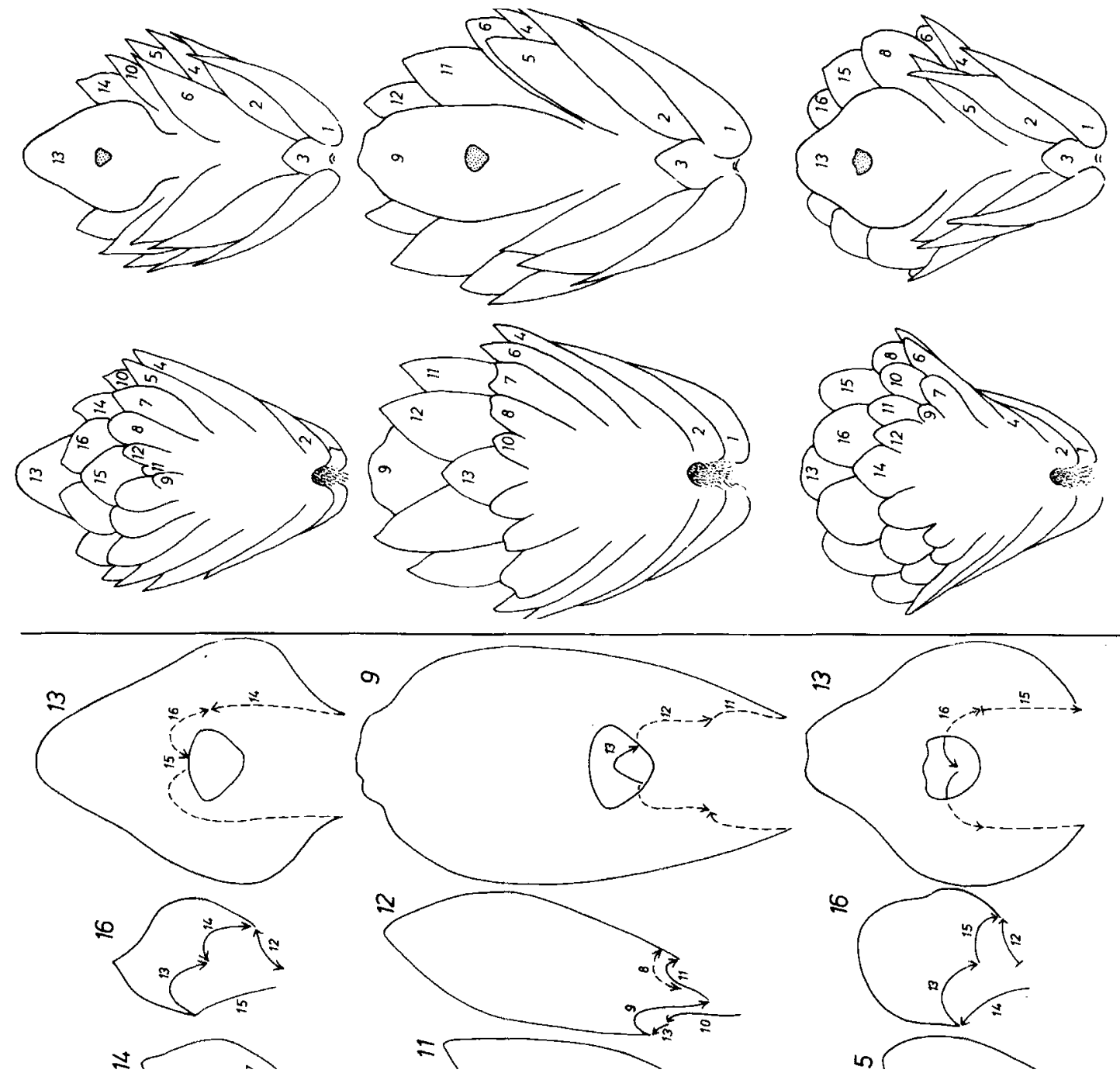


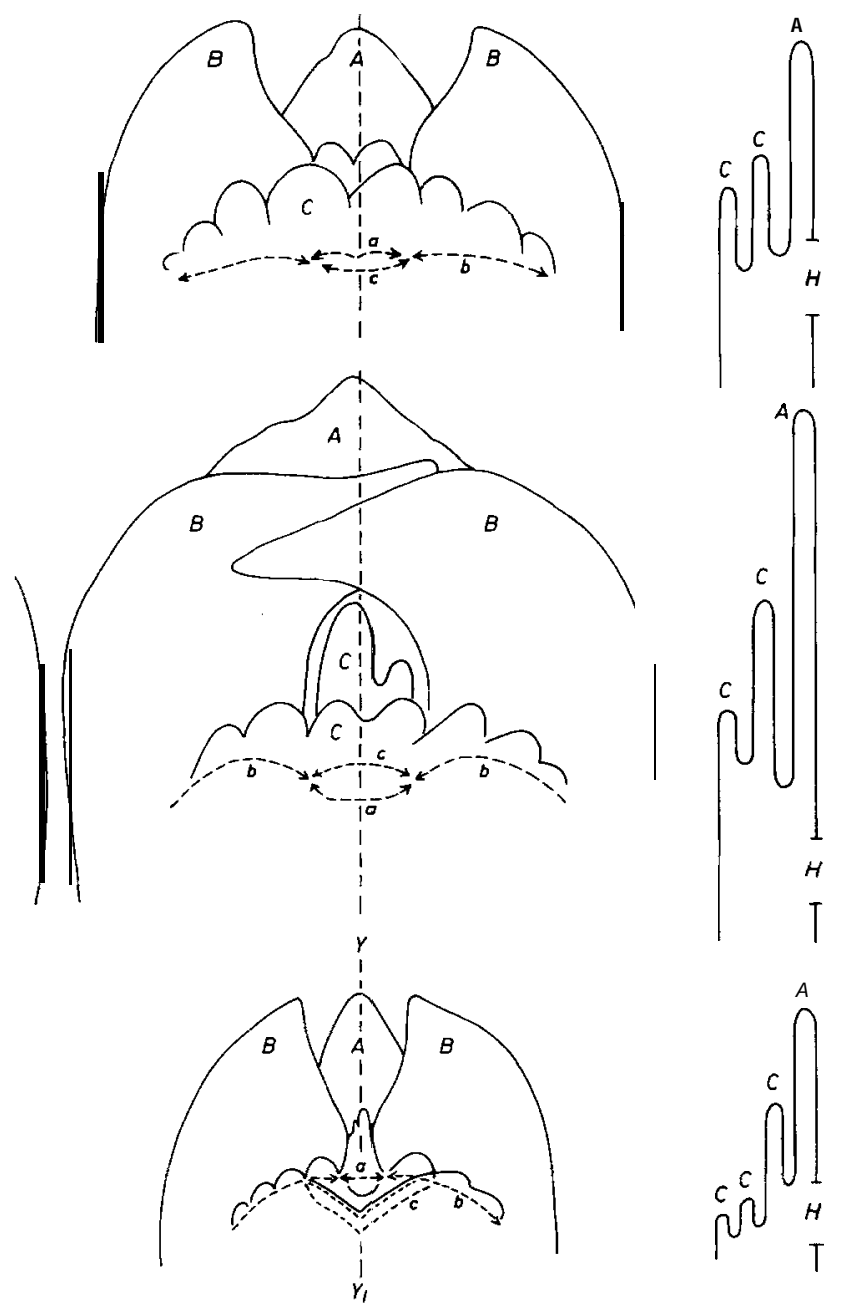

eri. $\mathbf{A}=$ median

bverse side; $H=$

upted lines with 
Plate XXIII, 4; Plate XXIV, 3; Plate XXIX, 5; Plate XXX, 3; Fig.12. For dimensions of stomata-free zones see Table II; Figs.1 and 12. A detailed organization of the stomatal complex is reconstructed in Fig.2a; further see Plate XXII, 3b; Plate XXIV, 1b; Plate XXXI, 3.

Epidermal papillae about $6 \mu \mathrm{m}$ in diameter, see Plate XXII, 3; Plate XXIV, 2b; Plate XXVII, 5; Plate XXIX, 5; Plate XXX, 3a.

Hair bases recognizable as two concentric circles; the smaller $(6 \mu \mathrm{m})$ situated on both sides of the cuticle, the larger $(17 \mu \mathrm{m})$ only on the exterior side, see Plate XXI, 6; Plate XXII, 3; Plate XXIII, 4; Plate XXIV, 1a and 2b; Plate XXV, 1; Plate XXVII, 5; Plate XXIX, 5; Plate XXXI, 2a and 3; Fig.2b.

Hairs about $50 \mu \mathrm{m}$ long (see Plate XXVIII, 3; Plate XXXI, 4).

For frequency of stomata, mean number of subsidiary cells/stomatal complex, mean dimensions of epidermal cells, occurrence of papillae and frequency of hair bases see Table III.

COMPARISON BETWEEN THE SPECIES ORTISEIA LEONARDI, O. VISSCHERI AND O. JONKERI

The above-described species have been differentially diagnosed on both macroscopical and epidermal characteristics. Comparison of Ortiseia leonardii, $O$. visscheri and $O$. jonkeri can be best performed by means of comparative morphological drawings and tabular arrangement of epidermal characteristics. In this way the comparative information concerning the three species can be practically applied in (1) the identification of plant elements on a species level, and (2) the recognition of the nature of separate remains (leaves, bracts, etc.). Macroscopical characteristics have been visualized in Figs.12-15; epidermal characteristics are represented in Figs.1, 2, 12 and Tables I-III.

\section{Macroscopical characteristics}

Macroscopical characteristics can be used for recognizing similarities and differences in the overall organization of shoots and cones.

Shoots. Because of their relative thin axes and small narrow leaves, the shoots of $O$. jonkeri obviously differ from those of $O$. leonardii and $O$. visscheri. Furthermore, the shoots of the three species can be distinguished on the basis of: (1) shape and relative distance of areas of leaf attachment on the leaves (see Plate V, 4; Plate XIV, 7; Plate XXII, 4);(2) shape (see Fig.12) and angle of arising and spreading of leaves (see Plate II, 1-3; Plate XII, 1-2; Plate XXI, 1; Plate XXIII, 1-3).

Ovuliferous cones. The species can be distinguished on the basis of (1) shape and size of bracts (see Fig.13); (2) shape, size, sequence and number of scales of ovuliferous dwarf-shoots (see Fig.14); (3) shape and size of ovules (see Figs.13 and 15). 
Polliniferous cones. The species can be distinguished on the basis of (1) shape and size of cones (see Plate II, 5; Plate XXI, 2; Plate XXX, 1 a and b); (2) shape and size of distal parts of microsporophylls (see Fig.12).

\section{Epidermal characteristics}

Epidermal characteristics can be applied for recognizing similarities and differences in epidermal structure, enabling the correlation of fertile and sterile remains within a single species.

The following characteristics may be applied: (1) situation and orientation of stomata (see Fig.12); (2) number of stomatal rows in basal, median and apical part of stomatiferous area (rows, doubled over some distance, to be counted as a single row); (3) mean distance of stomatal rows in basal, median and apical part of stomatiferous area (doubled rows, see 2), expressed in number of epidermal cells (between two stomatal complexes) and in $\mu \mathrm{m}$ (between two stomatal apertures) (see Fig.1); (4) mean distance of stomatal complexes in the rows, expressed in $\mu \mathrm{m}$ (see Fig.1); (5) width of marginal stomata-free zones, expressed in number of epidermal cells and in $\mu \mathrm{m}$ (see Fig.1); (6) presence and length of median stomata-free zones, expressed in $\mu \mathrm{m}$ (see Figs. 1 and 12); (7) presence of apical stomata-free zones (see Figs. 1 and 12$) ;(8)$ frequency of stomata, expressed in number per $\mathrm{mm}^{2} ;(9)$ mean number of subsidiary cells per stomatal complex; (10) presence of papillae on subsidiary cells; (11) mean dimensions of epidermal cells (longitudinally and transversally measured); (12) presence of papillae on epidermal cells; (13) frequency of hair bases, expressed in number per $\mathrm{mm}^{2}$; (14) diameter of inner and outer circle of hair bases; (15) thickness of anticlinal walls, measured halfway along an abaxial leaf surface; (16) thickness of cuticle, measured see 15; and (17) exterior of cuticle.

Results of the measurements with regard to the above-mentioned characteristics $(1-14)$ have been reproduced in Tables I-III. From these tables one can conclude that, despite similarities, the three species of Ortiseia can be readily distinguished on the basis of epidermal structure.

It is obvious, on the other hand, that within a single species the epidermis often shows variation. In particular, the epidermis of fertile parts frequently differ in some respects from that of sterile material. Therefore, it is necessary to recognize uniform epidermal characteristics, facilitating a correlation of fertile and sterile remains within a single species.

In Table III it is shown that in this respect a combination of two characteristics can be applied: mean number of subsidiary cells per stomatal complex, combined with presence or absence of papillae on the subsidiary cells. It should be noted that the mean number of subsidiary cells per stomatal complex for adaxial surfaces of leaves, bracts and distal parts of microsporophylls is a fraction smaller than that for abaxial surfaces; this difference, however, does not significantly affect the possibility of correlation.

For recognition of the nature of separate remains (leaves, bracts, etc.) other characteristics should also be taken into consideration, viz. the number 
of, and the distance between, stomatal rows (see Table II). It appears that on distal parts of microsporophylls the distance between the stomatal rows is more or less the same as on the leaves; on bracts and scales this distance is larger.

An additional important characteristic which can be used for comparison is the situation and orientation of stomata (see Fig.12 and Table II).

It is also possible to identify the axes on a species level; for this purpose a separate table has been composed (see Table I).

\section{Prepollen}

The term prepollen has been applied here rather than pollen because of (1) the presence of a proximal trilete mark, developed in both nexine and sexine, indicating the shedding of free antherozoids; and (2) the absence of a distal exinal thinning, indicating that no pollen tube was formed.

The prepollen of $O$. leonardii and $O$. jonkeri may be compared with the dispersed species Nuskoisporites dulhuntyi Potonie et Klaus 1954. The prepollen, ascribed to $O$. visscheri, can also be assigned to the palynological form genus Nuskoisporites Potonié et Klaus 1954, but no described species matches it completely. The prepollen of Ortiseia will be treated in a separate paper. A selection of scanning electron micrographs showing the overall organization of Nuskoisporites found in situ is given on Plate XXXII.

\section{COMPARISON BETWEEN ORTISEIA AND OTHER CONIFEROUS GENERA FROM THE UPPER PERMIAN OF EUROPE}

For an appreciation of the status of the genus Ortiseia, a comparison with coeval coniferous genera from the Upper Permian of Europe is necessary. In this respect, only genera from which both the ovuliferous fructifications and the epidermal structure are known, can be taken into consideration. These include the Late Permian genera Ullmannia Göppert 1850 (see description and discussion by Weigelt, 1928; Florin, 1944b; Schweitzer, 1962, 1963; Ullrich, 1964) and Pseudovoltzia Florin 1927 (see description and discussion by Florin, 1944b; Schweitzer, 1962, 1963 and Ullrich, 1964).

Shoots. According to Weigelt (1928) lateral shoot systems in a single plane may occur in Ullmannia (compare Archaeopodocarpus Weigelt) and Pseudovoltzia, however, because observations of the epidermal structure are lacking, the affinity of these shoot systems is uncertain. In contrast to Pseudovoltzia, Ortiseia is not markedly heterophyllous.

When comparing dispersed shoots of Ortiseia leonardii and Ortiseia visscheri with shoots of Ullmannia, a slight resemblance may be noticed. Some shoots, ascribed to Ullmannia, have been included in the genus Culmitzschia by Ullrich (1964) after investigation of the epidermal structure.

The macroscopical characteristics of leaves of the above-mentioned Permian genera are arranged in Table $\mathrm{V}$. 


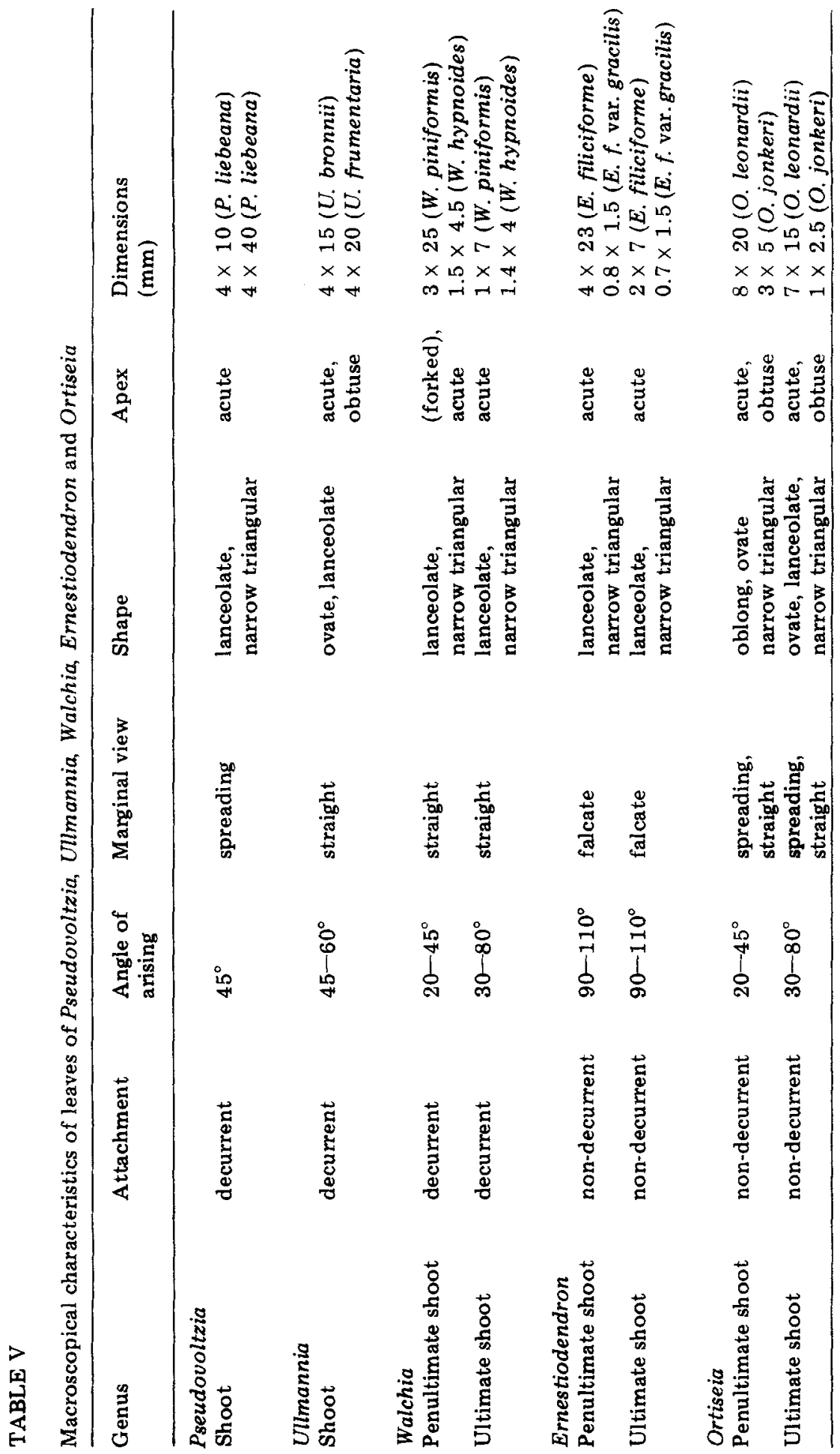


Ovuliferous cones. The ovuliferous dwarf-shoots of Ortiseia, provided with a large number of sterile scales and a single fertile scale, only partly fused, do not resemble those of Ullmannia and Pseudovoltzia; the latter show sterile and fertile scales situated in a single plane and largely adnated to each other; the basal part of the dwarf-shoot is stalk-like and partly fused with the bract.

Polliniferous cones. No conspicuous differences in general organization; cones of Ortiseia may be fairly large (up to $7 \mathrm{~cm}$ ) in comparison with cones of Ullmannia [U. frumentaria cone, described by Potonié and Schweitzer (1960) $2.5 \mathrm{~cm}$ long]. Polliniferous cones of Pseudovoltzia are sofar unknown.

Pollen. In contrast with the large, monosaccoid prepollen of Ortiseia, the pollen of Ullmannia frumentaria is rather small and bisaccoid.

Epidermal structure. Ortiseia differs from Ullmannia and Pseudovoltzia (epidermal structure of these species described by, e.g., Schweitzer, 1962; Ullrich, 1964) in showing hairs and (generally) dicyclic stomatal complexes (see Table VI).

\section{TABLE VI}

Epidermal characteristics of leaves of ultimate order of Pseudovoltzia, Ullmannia, Walchia, Ermestiodendron and Ortiseia

\begin{tabular}{|c|c|c|c|c|c|}
\hline \multicolumn{4}{|l|}{ Stomatal complexes } & \multirow[t]{2}{*}{ Hair bases } & \multirow{2}{*}{$\begin{array}{l}\text { Epidermal } \\
\text { papillae }\end{array}$} \\
\hline Situation & Organization & $\begin{array}{l}\text { Number of } \\
\text { subsidiary } \\
\text { cells }\end{array}$ & papillae & & \\
\hline $\begin{array}{l}\text { Pseudovoltzia } \\
\text { On both surfaces arranged in } \\
\text { single, longitudinal, often } \\
\text { interrupted rows }\end{array}$ & monocyclic & $4-10$ & present & absent & may occur \\
\hline $\begin{array}{l}\text { Ullmannia } \\
\text { On both surfaces arranged in single, } \\
\text { longitudinal, interrupted rows }\end{array}$ & monocyclic & $4-10$ & present & absent & may occur \\
\hline $\begin{array}{l}\text { Walchia } \\
\text { A baxial: Arranged in two bands or groups } \\
\text { often till halfway the surface, on both } \\
\text { sides of a stomata-free zone } \\
\text { Adaxial: arranged in two bands } \\
\text { reaching from base till near apex, on } \\
\text { both sides of a median stomata-free zone }\end{array}$ & $\begin{array}{l}\text { monocyclic } \\
\text { to incomplete } \\
\text { dicyclic }\end{array}$ & $4-10$ & present & present & may occur \\
\hline $\begin{array}{l}\text { Ernestiodendron } \\
\text { Arranged in single or, sometimes over } \\
\text { a short distance, doubled longitudinal } \\
\text { rows; on adaxial surface reaching till } \\
\text { near apex; on abaxial surface shorter }\end{array}$ & $\begin{array}{l}\text { monocyclic } \\
\text { to incomplete } \\
\text { dicyclic }\end{array}$ & $4-8$ & present & present & may occur \\
\hline $\begin{array}{l}\text { Ortiseia } \\
\text { A rranged in single or, sometimes over } \\
\text { a short distance, doubled longitudinal } \\
\text { rows; only in } O \text {. jonkeri apical (only } \\
\text { abaxial) and median stomata-free } \\
\text { zones present }\end{array}$ & $\begin{array}{l}\text { monocyclic } \\
\text { (only some- } \\
\text { times in } O . j . \text { ) } \\
\text { to incomplete } \\
\text { tricyclic }\end{array}$ & $4-8$ & may occur & present & may occur \\
\hline
\end{tabular}


From the above-mentioned comparisons it can be clearly concluded that the genus Ortiseia differs in many respects from coeval coniferous genera, such as Ullmannia and Pseudovoltzia in habitus, ovuliferous organs, pollen and epidermal structure.

\section{COMPARISON BETWEEN ORTISEIA AND THE LATE CARBONIFEROUS-EARLY PERMIAN CONIFEROUS GENERA WALCHIA AND ERNESTIODENDRON}

Comparison of Ortiseia with Late Carboniferous--Early Permian conifers from Europe indicates a great relationship, except in the organization of their ovuliferous cones as reconstructed by Florin (1938-1945). Therefore, in the following paragraphs - after a revision of the controversial status of the genus Walchia Sternberg - this presumed relationship will be discussed in detail; this discussion includes a reinterpretation of the organization of the ovuliferous dwarf-shoots of Walchia (synonym: Lebachia Florin) and Ernestiodendron.

\section{The genus Walchia}

In 1825 Sternberg founded the genus Walchia, with three species:

(1) W. filiciformis (Von Schlotheim) Sternberg (= Lycopodiolithes filiciformis Von Schlotheim pro parte)

(2) W. affinis Sternberg (= Lycopodiolithes filiciformis Von Schlotheim pro parte)

(3) W. piniformis (Von Schlotheim) Sternberg (= Lycopodiolithes piniformis Von Schlotheim)

Originally such remains were classified in the Lycopodiophyta (Von Schlotheim, 1820; Göppert, 1836), Algae (Fucoides hypnoides Brongniart 1828), or in the Filices (Sternberg, 1825). Brongniart (1837-1838) recognized their coniferalean affinity (see also Miquel, 1851).

Sternberg did not indicate a type-species. Later a type-species was selected by Miller (1889); this author chose Walchia piniformis.

According to Göppert (1864-65) and Florin (1938), Walchia affinis is conspecific with Walchia filiciformis.

In 1927 Florin divided Walchia Sternberg into two natural genera: Walchia Sternberg emend. Florin and Ernestia nov. gen. He based this division on differences in shape and epidermal structure of the leaves and the morphology of the ovuliferous cones. Later he changed the name Ernestia in Ernestiodendron (1934), for the first name had already been used for a recent plant genus. Although probably unaware of Miller's (1889) choice of a type-species, this procedure was nomenclaturally correct. Walchia filiciformis was transferred to Ernestiodendron, whereas $W$. piniformis remained in Walchia.

Subsequently, however, Florin introduced the genus Lebachia in 1938, based on Walchia piniformis, and retained the genus Walchia as a restricted form-genus (without type-species) for sterile remains, preserved without 
epidermal structure, but still comparable with Lebachia or Ernestiodendron on generic level. The holotypes of the type-species, Lebachia piniformis and Ernestiodendron filiciforme respectively, which he selected, are the original specimens of Walchia piniformis and Walchia affinis as figured by Sternberg; these specimens are preserved without epidermal structure, so paratypes with epidermal structure were necessary. Florin's indication of Ernestiodendron filiciforme as type-species for Ernestiodendron is correct, but his indication of the type-specimen of Walchia affinis as holotype for Ernestiodendron filiciforme (the holotype of Walchia filiciformis has been lost) is not justified.

These nomenclatural acts by Florin evoked some objections (e.g., Kräusel, 1939; Zimmermann, 1941, 1959), but no acceptable alternatives were given. Zimmermann (1959), without giving any reasons, considered the name Ernestiodendron to be invalid and used the name Walchia filiciformis, leaving Walchia piniformis, however, in Lebachia. According to the present author there are no nomenclatural arguments to reject the name Ermestiodendron filiciforme. Zimmermann's opinion is followed by Remy and Remy (1977). Also the above-mentioned authors apparently were unacquainted with Miller's choice of Walchia piniformis as the type-species of Walchia. Their procedure implies an incorrect typification of Walchia by W. filiciformis. Such a typification was suggested, but not formally proposed, in the Index of Generic Names of Fossil Plants (Andrews, 1970).

In summary the above nomenclatural history is the following:

Walchia Sternberg 1825

\begin{tabular}{lc}
\hline Walchia piniformis & Walchia filiciformis \\
\hline 1825 Walchia Sternberg & 1825 Walchia Sternberg \\
1927 Walchia Sternberg (emend. Florin) & 1927 Ernestia Florin \\
1938 Lebachia Florin & 1934 Ernestiodendron Florin \\
1984 Walchia Sternberg (emend. Clement- & 1959 Walchia Zimmermann non Sternberg \\
Westerhof, present paper) & 1984 Ernestiodendron Florin (emend. \\
& Clement-Westerhof, present paper) \\
& Walchia Florin 1939 non Sternberg \\
\hline
\end{tabular}

Because the indication of Walchia piniformis as type-species for Walchia is valid, the name Lebachia (type species Lebachia piniformis = Walchia piniformis) is illegitimate. Walchia Zimmerman 1959 and Walchia Florin 1939 are homonyms of Walchia Sternberg. Florin's earlier division $(1927,1934)$ of Walchia Sternberg into two genera - Walchia Sternberg (emend. Florin) and Ernestiodendron Florin - is correct and has to be followed in further taxonomic considerations.

\section{Comparison with Walchia and Ernestiodendron}

With the aid of the well-illustrated work by Florin (1938-1945), it was possible to compare shoots, fertile parts and epidermal structure of Ortiseia with those of Walchia ("Lebachia") and Ernestiodendron. 
Shoots. The lateral shoot systems of Ortiseia, especially $O$. jonkeri, show a general resemblance to those of Walchia and Ernestiodendron; the genera show differences in shape and insertion of leaves (see Table V). In Walchia and Ernestiodendron the differences in dimensions between leaves of penultimate and ultimate branches may be rather large; in Ortiseia this difference probably is smaller.

Ovuliferous cones. On the basis of the organization of the ovuliferous cones, particularly the ovuliferous dwarf-shoots, Florin (1944a) distinguished two types among the primitive conifers, viz. the Walchia Sternberg (= Lebachia Florin) and the Ernestiodendron type; both are characterized by spirally arranged forked bracts, with ovuliferous dwarf-shoots freely arising in their axils.

The Walchia type has been described by Florin (1944a, p.426; designated as Lebachia type) as follows:

"In jeder Tragblattachsel steht ein radiäire, oder nur wenig abgeflachter fertiler Kurztrieb, Samenschuppenkomplex, der vom Tragblatt etwas überragt wird, es aber an Masse wesentlich übertrifft. Er besteht aus einer kurzen Achse mit spiralig angeordneten, aufrecht-abstehenden, breit herablaufenden Schuppen. Die Zahl dieser Schuppen ist bei verschiedener Arten verschieden. Bei Lebachia piniformis beträgt sie etwa 14. In der Regel ist nur einzige etwa mediane Schuppe, und zwar auf der der Abstammungsachse zugekehrten Seite des Samenschuppenkomplexes fertil und trägt eine stets aufrechte Samenanlage als direkte Fortsetzung ihrer basalen Partie (Samenschuppe). Alle übrige Schuppen sind steril."

Only in Walchia piniformis the number of sterile scales has been mentioned; with regard to the other species the descriptions only mention the presence of sterile scales. Florin (1944a, fig.33h) figures a dwarf-shoot, ascribed to Walchiostrobus (Lebachia?) elongatus with at least thirty sterile scales.

The Ernestiodendron type has been characterized by Florin (1944a, p.429) as follows:

"In jedex Tragblattachsel steht ein fertiler, mehr oder weniger abgeflachter und fächerförmiger Kurztrieb, ein Samenschuppenkomplex, der entweder die Länge des Tragblattes erreicht oder sie sogar etwas iberragt oder auch von ihr mehr oder weniger iberragt wird, aber sie an Masse stets wesentlich übertrifft. Er besteht aus einer kurzen Achse, die zahlreiche bis weniger, ursprunglich offenbar spiralig angeordnete, aufrecht-abstehende und breit herablaufende Schuppen trägt. Die Zahl dieser Schuppen ist bei verschiedenen Arten sehr verschieden. Bei gewissen Formen beträgt sie wenigstens 20-30, während Ernestiodendron filiciforme nur etwa 3-5 Schuppen je Samenschuppenkomplex aufweist. Bei den mit zahlreichen Schuppen ausgeruistete Formen trägt jeder Samenschuppenkomplex etwa 4-6 kräftige Samenschuppen, während die übrigen steril bleiben. Diese sterilen Schuppen sind in der basalen Region klein, werden aber distalwärts breiter und vor allem länger, ohne jedoch die Grösse der fertilen zu erreichen. Bei Walchia (Ernestiodendron?) germanica sind die sterile Schuppen fast verschwunden. Nur vereinzelt können sie noch hier und da festgestellt werden.

Ernestiodendron filiciforme verhält sich ebenso. Die Zahl der Samenschuppen beträgt bei der letztgenannten Art etwa 3-5, schwankt aber bei Walchia (Ernestiodendron?) germanica wahrscheinlich zwischen 3 und 7 . Jede Samenschuppe trägt als direkte 
Fortsetzung ihrer basalen Partie eine terminale Samenanlage, die entweder aufrecht (z.B. bei Ernestiodendron filiciforme und Walchia (Ernestiodendron?) arnhardtii) oder auch umgewendet ist (z.B. bei Walchia (Ernestiodendron?) germanica)."

In trying to correlate the ovuliferous dwarf-shoot of Ortiseia with Florin's concept of the Walchia type, the present author found one great difference in organization. Both Ortiseia and Walchia bear a single ovule. However, in Ortiseia the ovule is inserted on the abaxial surface of a foliaceous ovuliferous scale and inverted, whereas in Walchia the ovule is reported to be terminally inserted on a stalk-like megasporophyll and erect (micropyle averted from the cone axis). Such a prominent difference in organization of the ovuliferous cone should represent a principal argument against a close relationship.

However, as a result of a detailed analysis of Florin's descriptions and photographs, it is here considered that his interpretation is by no means indisputable. In this respect at least the following facts are remarkable (see Florin, 1938, p.47; plate XXI/XXII, 1-3; plate XIX/XX, 10-11, 30; and present paper, Fig.16): (1) there is no distinct border between "ovule" and fertile scale (megasporophyll) (p.47); (2) the epidermal structure of the "ovule" strongly resembles that of the sterile scales (p.47; plate XXI/XXII, 1-3; (3) a scar-like structure ("Nuzellusscheitel" according to Florin) is clearly visible on the "ovules" of the dwarf-shoots [figured on plate XIX/XX, 10, 11 (retouched figure), 30]. Moreover, it should be noted that Florin never described or figured fertile scales without ovules.

Considering these points, another interpretation may be suggested: The presumed "stalked" ovule of Walchia is not an ovule at all, but represents a bilobate fertile scale, without ovule; the scar represents the place of insertion of an ovule. If this interpretation is correct, there is a conspicuous general resemblance with the ovuliferous dwarf-shoots of Ortiseia (see also Fig.16).

The spiral arrangement of the scales of the dwarf-shoots of Walchia as described by Florin (1938) cannot be convincingly concluded from his unretouched illustrations (1938, plate XIX/XX, 4, 6, 8, 10, 28-30); at least the adaxial side is nearly bilaterally symmetrical. This view may be confined by observations on dwarf-shoots, assignable to Walchia, collected by J.H.F. Kerp and K. Baum from the Lower Permian of Sobernheim (Saar, Nahe Basin, F.G.R.). These specimens (Plate XXXIII, 1, 2) clearly exhibit a bilaterally symmetrical arrangement of scales. On the centrally emerging bilobated scale one may observe the contours of a small ovule (Plate XXXIII, 1a), morphologically comparable with both the dispersed seeds from the same locality (Plate XXXIII, 3) and a reconstruction of an ovule given by Florin (1944a, fig.32g). These specimens are characterized by two small integumentary extensions (for reconstruction see Fig.16).

It should be noted that some ovuliferous dwarf-shoots, belonging to Ortiseia jonkeri show fertile scales with slightly bilobate apices (Plate XXVIII, 2).

Also with Florin's description of the ovuliferous cones, particularly the ovuliferous dwarf-shoot, of Ernestiodendron, the present author cannot 


\section{O.JONKERI}
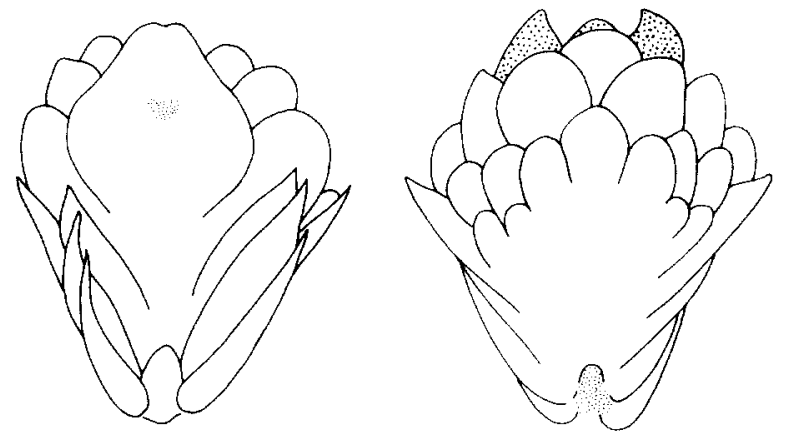

W. PINIFORMIS
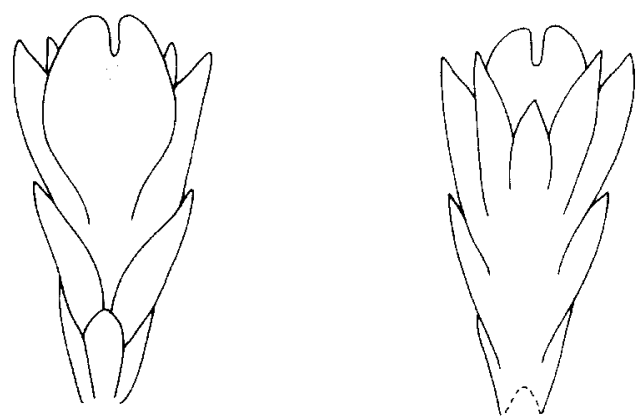

W. PINIFORMIS (after Florin)

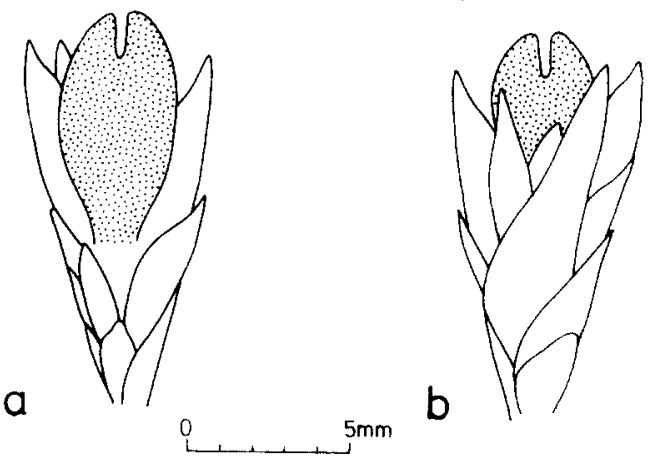

Fig. 16. Comparative scheme of ovuliferous dwarf-shoots, ovules and bracts of Ortiseia (represented by $O$. jonkeri) and Walchia (represented by $W$. piniformis). Walchia is represented by two versions, viz. the reconstruction of the present author and the concept of Florin (1938). Ovule dotted, bract hatched. a. Ovuliferous dwarf-shoot, ovule detached, 

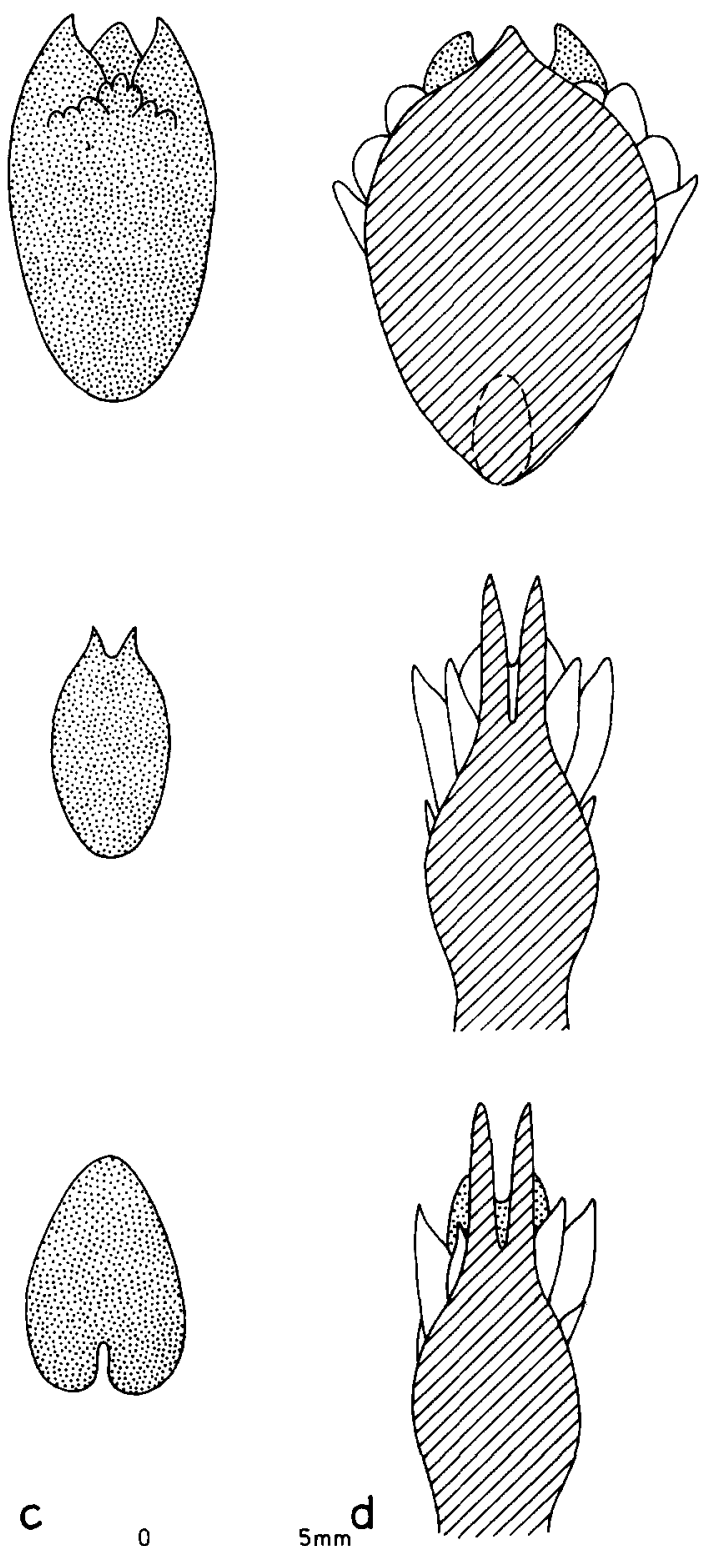

adaxial view (N.B.: in the concept of Florin: stalked ovule). b. Ovuliferous dwarf-shoot with ovule, abaxial view. c. Detached ovule/seed, reverse view (in Walchia the presumed position of the micropyle is at the lower side of the drawings). d. Bract, ovuliferous dwarf-shoot and ovule, abaxial view. 
agree in all respects. A disputable point is the number of fertile scales, that Florin considered to be present in dwarf-shoots of Ernestiodendron. The photographs of ovuliferous cones of Ernestiodendron filiciforme Florin (1939c, plate CXIX/CXX, 3-6) show dwarf-shoots with a single fertile scale; in the basal part of the dwarf-shoot occur some sterile scales. The dwarf-shoots clearly extend beyond the bracts. In some cases two ovuliferous scales are visible (1939c, plate CXVII/CXVIII, 21; plate CXIX/CXX, 7) which, according to Florin, belong to a single dwarf-shoot. On the basis of this material, more specifically on the specimen figured on plate CXIX/ CXX, 7. Florin made his reconstruction of the dwarf-shoot of Ernestiodendron with five (!) ovuliferous scales and without any sterile scales (1944a, fig.36). It is here considered that Florin's assumption of the presence of five ovuliferous scales is unsubstantiated; moreover, it might well be possible that the two visible ovuliferous scales belong to two separate dwarf-shoots, compressed across each other.

In this context it is interesting to note that already Zeiller (1892, p.99; plate XV, 3) described an ovuliferous cone, probably of Ernestiodendron filiciforme (under the name Walchiostrobus filiciforme) showing a single ovule per dwarf-shoot. In the light of his own ideas Florin (1939; p.196) regarded Zeiller's description to be erroneous.

Another questionable point is the presumed presence of stalked ovules; the objects, regarded by Florin as terminal ovules show a rotund structure. If one alternatively interpretes the objects in terms of an ovuliferous scale similar to the situation in Walchia - rather than a stalked ovule, this structure might represent a place of insertion of an ovule. In that case, however, the place of insertion would be rather large, compared with Walchia. It is also possible that it concerns the impression of a small ovule. Unfortunately, Florin's material of Ernestiodendron is not very conclusive in this respect.

An organization, clearly differing from that in both Walchia and Ernestiodendron may be found in some ovuliferous cones, described as Walchia (Ernestiodendron?) germanica by Florin (1939c, pp.237-241; plate CXLIX/CL, 1-4, 13-16). Here it obviously concerns a fan-shaped, strongly flattened dwarf-shoot with 3-8 fertile scales, subtended by a bract protruding beyond the dwarf-shoot. The cone-bearing shoots differ from those of Ernestiodendron (leaves rather long, up to $35 \mathrm{~mm}$, not extremely spreading). On the other hand, the cones show a resemblance to Walchiostrobus (Ernestiodendron?) fasciculatus and Walchiostrobus sp. though the latter show sterile scales at the bases of the dwarf-shoots (Florin, 1940, plate CLIII/CLIV, 11-22; plate CLXIII/CLXIV, 3 and 4, respectively).

Summarizing the above discussion, the present author suggests the possibility that Florin founded the description of the Ernestiodendron type of cones on two different types: (1) Ernestiodendron filiciforme, probably bearing a single ovule per dwarf-shoot; (2) "Walchia (Ernestiodendron?) germanica" together with some species of Walchiostrobus sp., showing fanshaped, strongly flattened dwarf-shoots, bearing several ovules. 
Ovule/seed. If the present interpretation of the organization of the ovuliferous dwarf-shoot of Walchia is right, also Florin's description of the ovule has to be reconsidered. An ovuliferous cone of Walchia ("Lebachia") hypnoides, figured by Florin on plate CIX/CX, $24(1939 \mathrm{~b})$, shows ovate ovules, $6.5-9 \mathrm{~mm}$ long $5-6.5 \mathrm{~mm}$ wide. Plate XXI/XXII, 17 represents an incomplete ovule, isolated from a Walchia cone; a reconstruction of this ovule is given in Florin (1944a, fig.32g), and in contradiction to Florin's other reconstructions of Walchia ovules, in this ovule the micropyle has been reconstructed at the tapering end. As mentioned before, this specimen resembles the seed found in Sobernheim (Plate XXXII, 2).

A longitudinal section of a Walchia "ovule", with the micropyle situated between integumentary extensions, has been figured by Florin (1944a, fig. 32f). For a comparison with the ovule of Ortiseia, see Fig.17.

The ovule/seed of Ernestiodendron is hardly described by Florin. The ovuliferous cone he figured on plate CXV/CXVI, 10 and 11 (1939c), may contain ovules, $9 \mathrm{~mm}$ long, $5 \mathrm{~mm}$ wide.

According to Florin it is possible that some dispersed seeds, classified in the genus Samaropsis (Florin, 1940, plate CLXI/CLXII, 2, 5, 20) may belong to Walchia or Ernestiodendron. It should be noted that these seeds resemble in some degree dispersed seeds of Ortiseia, which are still embedded in the sediment; the latter seeds are always preserved with the reverse side visible, so that the median integumentary extension remains practically invisible (Plate XXVIII, 5).

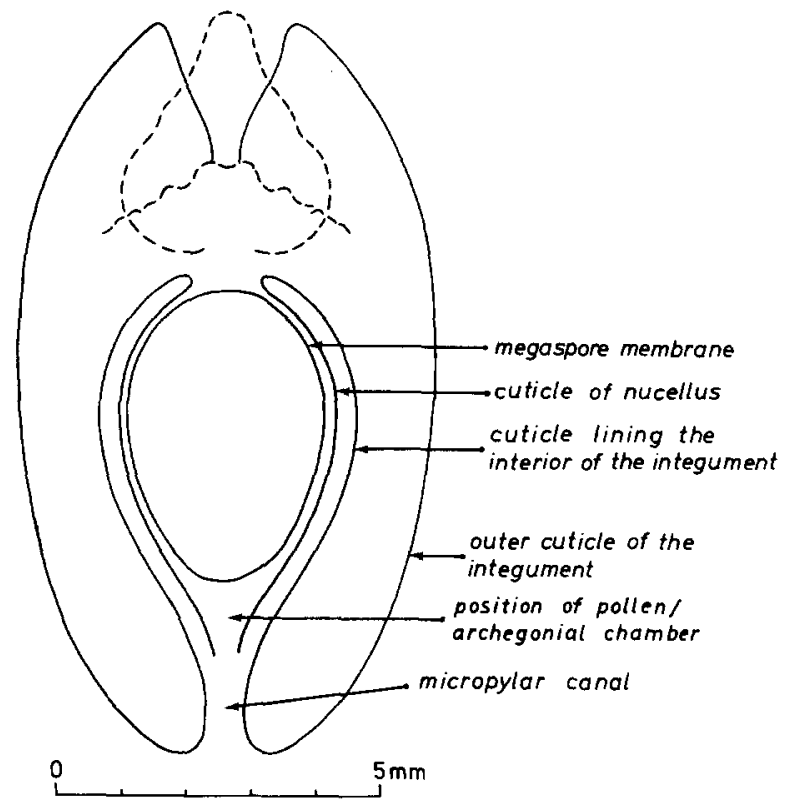

Fig.17. Reconstruction (longitudinal section) and terminology of the ovule/seed of Ortiseia. 
Polliniferous cones. There is no conspicuous difference in general organization with cones of Walchia and Ernestiodendron; cones of Ortiseia leonardii and Walchia piniformis may have a similar size range (up to $7 \mathrm{~cm}$ ). Distal parts of microsporophylls in Ortiseia are relatively wide, compared with those of Walchia and Ernestiodendron (3-6 $\mathrm{mm}$ and $1-1.5 \mathrm{~mm}$, respectively). Place and number of pollen sacs in Ortiseia are unknown; microsporophylls in Walchia and Ernestiodendron are hyposporangiate and bisporangiate according to Florin $(1938-1945,1951)$.

Pollen. Monosaccoid and fairly large prepollen may occur in all three genera [Ortiseia: Nuskoisporites Potonié et Klaus 1954; Walchia and Ernestiodendron: Potoneisporites Bhardwaj 1954 (compare Bharadwaj, 1964)].

Epidermal structure (see Table VI). Remarkable is that Ortiseia leonardii and $O$. visscheri have some characteristics in common with Ernestiodendron (stomata arranged in single longitudinal rows, sometimes doubled over some distance; no apical and median stomata-free zones, at least on leaves of ultimate shoots); the situation of stomata in Ortiseia jonkeri resembles in some degree that of Walchia, though in Ortiseia jonkeri the stomata are generally arranged in longitudinal rows, except on distal parts of microsporophylls. Here the stomata are arranged in short rows or groups on both sides of a median stomata-free zone (Plate XXIX, 5; Plate XXX, 3 a and b) and the apical area of the abaxial surfaces is stomata-free. This matches the leaves of ultimate shoots of Walchia.

Recapitulating the preceding comparisons between Ortiseia and the genera Walchia and Ernestiodendron, the following conclusions and suggestions may be made:

(1) These comparisons show the existence of a high degree of similarity with respect to the following characters: (a) the general organization of the lateral shoot-systems; (b) the organization of the polliniferous cones (fairly large; prepollen monosaccoid); and (c) epidermal structure (presence of hair bases).

(2) When comparing the ovuliferous dwarf-shoots of Ortiseia with those of Walchia and Ernestiodendron, it may be concluded that Florin's interpretation of the organization of the ovuliferous dwarf-shoots of the latter genera cannot be maintained: the fertile scale has been erroneously interpreted in terms of an ovule. Thus, also the ovuliferous dwarf-shoots of the three genera show a remarkable resemblance.

(3) It seems well possible that Florin founded the description of the Ernestiodendron type of ovuliferous dwarf-shoots on two different types. It can also be suggested that in the Lower Permian a third important coniferous genus was present, with ovuliferous cones of the Walchiostrobus type. 
EMENDED DIAGNOSES OF THE FAMILY WALCHIACEAE AND THE GENERA WALCHIA AND ERNESTIODENDRON

From the above discussion it may be concluded that there is a striking resemblance between the Late Permian genus Ortiseia and the Early Permian genera Walchia and Ernestiodendron, indicating a close natural relationship. It is considered therefore, that the three genera should be classified within the same family, viz. the Walchiaceae (Göppert 1865) Schimper 1870. In the following paragraphs a new diagnosis of this family is provided together with emended diagnoses of the genera Walchia and Ernestiodendron. Acceptable species of Walchia, as well as species excludendae are listed.

Family Walchiaceae (Göppert 1865) Schimper 1870

1945 Lebachiaceae Florin

1959 Walchiaceae Zimmermann

1977 Walchiaceae Remy et Remy

Type-genus (indicated by Göppert, 1865): Walchia Sternberg

Nomenclatural remarks: The name Walchieae was validly published by Göppert (1864-1865, p.234; publication probably in 1865) for a suprageneric taxon without a clear indication of rank. The name was assigned family rank by Schimper (1870-1872, p.235; published in 1870). Considering also the improper termination eae for the name of a family, the taxon is to be cited as Walchiaceae (Göppert) Schimper.

In subsequent work the name Walchi(ac)eae has hardly been applied. In general this may be ascribed to the fact that Walchia has been treated as either a conifer of uncertain affinity or as a fossil representative of some extant family of conifers (usually the Araucariaceae) and the application of the name Lebachiaceae, which became widely accepted after its introduction by Florin (1945). Since Lebachia is a nomenclatural synonym of Walchia Sternberg (see p.100), the name Lebachiaceae is a illegitimate synonym. In some cases one may find the citation "Lebachiaceae (Walchiaceae)". A few authors (Zimmermann, 1959; Remy and Remy, 1977) have re-introduced the name Walchiaceae, obviously to replace the name Lebachiaceae for other than nomenclatural reasons. Without reference to the original author, their concept of the family is based on the homonymous concept of Walchia, typified by Walchia filiciformis (cf. p.100).

Emended diagnosis: Conifers. Stem containing true eustele with endarch protoxylem. Primary wood poorly developed, secondary wood composed of tracheids of the araucarioid type. Wood parenchyma sporadically, no resin canals. Tracheids showing 1-3 rows of closely arranged alternating bordering pits in their radial walls. Wood rays uniseriate, pith relatively thick (Florin, 1951, pp.323-325). 
Presumed main axis leafy at younger stage. Pinnately branched lateral shoot systems, consisting of a penultimate branch with two lateral series of parallel ultimate branches, situated in one plane. Leaves spirally arranged. Compound ovuliferous cone; cone axis bearing spirally arranged bracts with ovuliferous dwarf-shoots, freely arising in their axils. Ovuliferous dwarfshoots provided with a number of sterile scales and a single fertile scale, emerging on the adaxial side. Fertile scale bearing a single inverted ovule on its abaxial surface.

Ovule/seed bilaterally symmetrical, platyspermic. Nucellus free to its base; pollen/archegonial chamber present.

Polliniferous cone simple, cone axis bearing spirally arranged hyposporangiate microsporophylls, slightly overlapping. Prepollen circular to elliptical in polar view. Equatorial sexine expanded to a monosaccoid differentiation. Proximal monolete, dilete or trilete mark in both nexine and sexine. No apparent distal exinal thinning.

Epidermal structure. Leaves, bracts, etc., amphistomatic; stomata situated in longitudinal bands or rows. Stomatal complexes mono- to tricyclic; 4-8 subsidiary cells, sometimes bearing papillae. Hair bases present. Papillae on epidermal cells may occur.

\section{Genus Walchia Sternberg 1825 emend.}

\section{Lebachia Florin}

Type-species (selected by Miller, 1889, p.149): Walchia piniformis Sternberg 1825.

Lectotype of the type-species (selected by Florin, 1938, p.10, 25): the specimen figured and described as Lycopodiolythes piniformis by Von Schlotheim (1820, plate XXIII, 1a; p.415); refigured by Florin (1938, plate I/II, 1-2)

Nomenclatural remarks: See pp. 100-101.

Emended diagnosis: Because Florin's diagnose of Lebachia (see Florin, 1938 , p.23) is rather complete, the present author maintains this diagnosis for Walchia, except the phrases describing the organization of the ovuliferous cones and the prepollen; the latter will be described and discussed in a separate paper.

The emended diagnosis concerning the ovuliferous cone is as follows: Ovuliferous cone compound, cylindric; cone axis bearing spirally arranged bracts with forked apices; ovuliferous dwarf-shoots freely arising in bract axils, not reaching apices of bracts, (radially to) bilaterally symmetrical, slightly flattened, provided with a number of sterile scales and a single fertile scale, emerging on the adaxial side. Shape of sterile scales ranging from narrow-subtriangular to lanceolate. Fertile scale obovate with bilobated apex, projecting beyond the sterile scales and bearing a single inverted ovule on its abaxial surface. 
Ovule/seed platyspermic, bilaterally symmetrical, elliptical or ovate.

Species recognized: The following species are sufficiently well-known to justify their inclusion in a natural concept of the genus Walchia:

Walchia piniformis Sternberg 1825

Walchia hypnoides (Brongniart 1828) Brongniart 1849.

Walchia garnettensis (Florin) nov. comb.

Basionym: Lebachia garnettensis, Florin 1939a, Palaeontographica, B 85, p.96.

Holotype: the specimen, figured as Walchia sp. by Moore (1933, fig.228).

Walchia goeppertiana (Florin) nov. comb.

Basionym: Lebachia goeppertiana, Florin 1939a, Palaeontographica, B 85, p.83.

Holotype: the specimen figured by Florin (1939a, plate XLIII/XLIV, 1)

The following species or combinations have to be excluded from Walchia:

[for references, except W. bipinnata, see Fossilium Catalogus (Dijkstra, 1975)] :

W. abaeana Zalessky 1937

W. affinis Sternberg 1825

W. angustifolia Emmons 1857

W. antecedens Stur 1875

W. appressa Zalessky 1937

W. arnhardtii Florin 1939

W. bardaena Zalessky 1937

W. bertrandii Florin 1939

W. biarmica (Eichwald) Schimper 1870-1872

W. bipinnata Lee et al. 1974

W. borea Zalessky et Tschirkova 1937

W. brevifolia Emmons 1857

W. carpientieri Florin 1939

W. cutassaeformis Brongniart 1849

W. dawsonii White 1929

W. densa Zalessky 1939

W. diffusa Emmons 1857

W. eutassaeformis Brongniart 1849

W. fertilis Renault 1893-1896

W. filiciformis (Von Schlotheim) Sternberg 1825

W. flaccida Göppert 1864-1865

W. foliosa Eichwald 1854

W. frondosa Renault 1865

W. gallica Florin 1939

W. geinitzii Florin 1939

W. germanica Florin 1939

W. gracilis Emmons 1857

W. gracilis Dawson 1871 non Emmons 1857

W. gracillima White 1929

W. grandeuryi Saporta et Marion 1885

W. gravenhorstii Brongniart 1838

W. hirmeri (Florin) Doubinger et Kruseman 1965

W. hoeninghausi Brongniart 1838
W. imbricata Schimper 1870-1872

W. imbricatula Dawson 1885

W. kassagatschica Tschirkova 1937

W. kurtzii Frenguelli 1949

W. lanceolata (Göppert) Schimper 1870-1872

W. laxifolia (Florin) Nemejc 1968

W. linearifolia Göppert 1864-1865

W. longifolia Emmons 1857

W. longifolia Göppert 1864-1865 non Emmons 1857

W. lycopodioides (Brongniart) Eichwald 1854

W. milneana Tenison-Woods 1884

W. minuta Florin 1939

W. parvifolia Florin 1939

W. patens Brongniart 1837

W. peremiana Zalessky 1937

W. pinnata Gutbier 1849

W. polyphylla (Brongniart) Göppert 1848

W. rigidula Florin 1939

W. robusta Dawson 1871

W. schlotheimii Brongniart 1849

W. schneideri Zeiller 1906

W. sillimanii Brongniart 1828

W. spinulifolia Zalessky 1936

W. stephanensis Florin 1939

W. sternbergii Brongniart 1849

W. stricta Florin 1939

W. tasmanica Johnston 1888

W. uralica Zalessky 1937

W. valdajolensis (Mougeot) Seward 1919

W. variabilis Emmons 1857

W. whitei Florin 1939

W. williamsonis Brongniart 1828 
Genus Ernestiodendron Florin 1934 emend.

1927 Ernestia Florin

1934 Ernestiodendron Florin

1959 Walchia Zimmermann non Sternberg

Type-species: Ernestiodendron filiciforme (Sternberg) Florin 1934.

Holotype of the type-species (designated by Sternberg, 1825, p.XXII): the specimen figured and described as Lycopodiolythes filiciformis by Von Schlotheim (1820, plate XXIV, p.414).

Nomenclatural remarks: See pp. 100-101.

Emended diagnosis: The present author maintains the diagnosis given by Florin (1939c, p.176), except the phrases describing the organization of the ovuliferous cone and the prepollen; the latter will be described and discussed in a separate paper.

The emended diagnosis concerning the ovuliferous cone is as follows: Ovuliferous cone compound, cylindric; cone-axis bearing bracts in a loose spiral. Ovuliferous dwarf-shoots freely arising in bract axils, reaching beyond apices of bracts, provided with a number of sterile scales and a single fertile scale, bearing a single ovule on its abaxial surface.

Species recognized: Apart from the type-species, E. filiciforme, no other species have so far been included in Ermestiodendron. Walchia affinis should be regarded as a synonym of the type-species.

\section{CULMITZSCHIA ULLRICH 1964 EMEND., A WALCHIACEOUS FORM-GENUS}

On the basis of some shoots and dispersed cuticles, Ullich (1964) established the form-genus Culmitzschia. The original diagnosis of the genus is quoted here, because of the relative obscurity of the publication concerned:

\footnotetext{
"Konifere mit mehr oder weniger dreieckigen, 10 bis $15 \mathrm{~mm}$ (sogar 20 bis $35 \mathrm{~mm}$ !) langen, in der Nähe des: Blattgrundes etwa $5 \mathrm{~mm}$ (bis $10 \mathrm{~mm}$ !) breiten Blättern in ziemlich dichter, etwa sci raubiger Anord! ung. Blattspitze fast stets spitz erscheinend. Vollständig amphizyklische (di- bis trizyklische) Spaltöffnungsapparate auf beiden Blattseiten in einzeiligen (sehr often zweizeiligen) Längsreihen. Anzahl der Nebenzellen 4 bis 8 , hauptsächlich 6. Kranzzellen in etwa gleicher Anzahl. Epidermiszellen verhältnismässig klein. Haarbasen $z$ wischen und in der Spaltöffnungsreihen. Nebenzellen und Epidermiszellen ohne Papillen. Die Epidermisstruktur gestattet eine eindeutige Unterscheidung genenüber allen aus dem Zechstein bekannten Gattungen.

Genotypus: Culmitzschia florinii, nov. spec."
}

This diagnosis does not show fundamental differences with the original diagnosis Florin (1964) composed for Ortiseia. A minor difference (on a generic level) is the absence of papillae in Culmitzschia. However, on plate XV, 5 (Ullrich, 1964), showing a stomatal complex, some papillae are visible! 
Similar to Ortiseia, the name Culmitzschia is only very infrequently cited in palaeobotanical studies. Schweitzer (1968) briefly mentioned the genus in a summary concerning the Late Permian flora in Middle Europe. Remy and Remy (1978) described isolated leaves from the Tregiovo Formation of the Lombardic Alps, which might represent the genus; since cuticles are not preserved, however, these identifications remained tentative.

It has already been mentioned (p.61) that on the form-genus level $\mathrm{Cul}$ mitzschia could well be regarded as a synonym of Ortiseia. Moreover, as a form-genus Culmitzschia is less appropriate than Ortiseia in its original concept.

On the basis of the descriptions that Ullrich has given from several dispersed cuticle fragments (especially the mean number of subsidiary cells/ stomatal complex) the present author concluded that Ullich ascribed material to his type-species $C$. florinii, that possibly belongs to several natural species. Therefore, it remains impossible to correlate the type-species of Culmitzschia with the known species of Ortiseia.

However, as a result of the present investigation, it has been possible to "promote" Ortiseia to a natural status. Consequently, it may be considered whether or not Culmitzschia may still serve as a practical form-genus in the classification of coniferous remains.

In Polish material, obtained from a borehole in the Zechstein, the present author discovered cuticle fragments that could be identified as belonging to the genus Ortiseia (see Plate XXXIII, 4, 5); it is not possible to identify this material in terms of the known natural species. Within a form-genus concept however, it is well possible to classify this material as Culmitzschia florinii. Since, in general terms, it may be possible to recognize the walchiaceous affinity of plant remains, even without identifications in terms of natural genera and/or species, the present author proposes to retain the genus Culmitzschia (with an emended diagnosis) as a form-genus for shoots showing epidermal structure and dispersed cuticle fragments within the Walchiaceae, viz. for remains, not assignable to a known reconstructed species of the natural genera Walchia, Ernestiodendron and Ortiseia. In time, similar walchiaceous form-genera should be established (or emended) to accommodate other organs.

It is possible that, when during later investigations such remains may be correlated with ovuliferous organs, a natural rank is gained and the species can be transferred from Culmitzschia to a natural walchiaceous genus.

The present taxonomic procedures have the consequence that the species with epidermal structure but without ovuliferous cones (or cones of which the organization cannot be sufficiently examined), ascribed by Florin to Lebachia, cannot be considered as natural taxa. Therefore, they will be classified in the form-genus Culmitzschia.

Form-genus: Culmitzschia Ullrich 1964

Type-species: Culmitzschia florinii Ullrich 1964

Holotype of the type-species: The specimen figured and described as 
Strobilifer Weigelt (?) by Schuster (1933, fig.6, p.88; compare Ullrich, 1964, p.100); present paper Fig.18.

Emended diagnosis: Shoots with spirally arranged leaves. Leaves amphistomatic; stomata situated in longitudinal bands or rows; stomata mono- to tricyclic; number of subsidiary cells $4-10$; hair bases present; papillae may occur on subsidiary cells and epidermal cells.

Species recognized:

Culmitzschia florinii

Culmitzschia americana (Florin) nov. comb.

Basionym: Lebachia americana Florin 1939b, Palaeontographica, B 85, p.150.

Holotype: The specimen figured by Florin (1939b, plate XCIII/XCIV, 5-6).

Culmitzschia angustifolia (Florin) nov. comb.

Basionym: Lebachia angustifolia Florin 1939a, Palaeontographica, B 85, p.78.

Holotype: The specimen figured by Florin (1939a, plate XXXIX/XL, 9).

Culmitzschia frondosa (Renault) nov. comb.

Basionym: Walchia frondosa Renault 1885 , Cours de botanique foss., 4, p. 89 .

Holotype: The specimen figured by Renault (1885, plate VII, $6 ; 1893-1896$, plate LXXVIII, 1).

Culmitzschia hirmeri (Florin) nov. comb.

Basionym: Lebachia hirmeri Florin 1939b, Palaeontographica, B 85, p.147.

Holotype: The specimen figured by Florin (1939b, plate XCI/XCII, 1-4).

Culmitzschia intermedia (Florin) nov. comb.

Basionym: Le bachia intermedia Florin 1939b, Palaeontographica, B 85, p.128.

Holotype: The specimen figured by Florin (1939b, plate LXXVII/LXXVIII, 4-5).

Culmitzschia laxifolia (Florin) nov. comb.

Basionym: Lebachia laxifolia Florin 1939a, Palaeontographica, B 85, p.101.

Holotype: The specimen figured by Florin (1939a, plate LIII/LIV, 9).

Culmitzschia mitis (Florin) nov. comb.

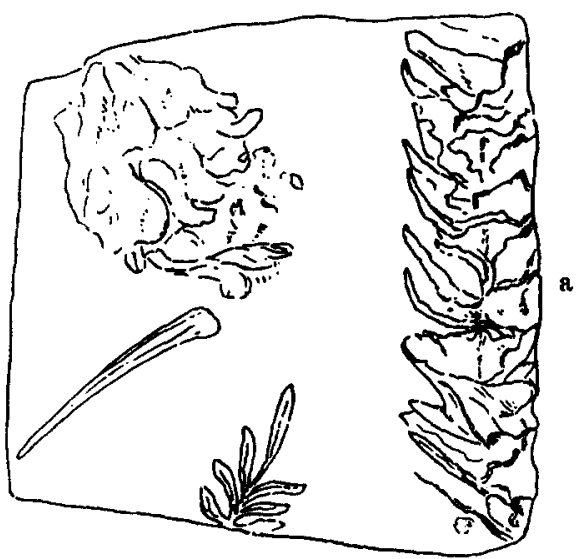

Fig. 18. Holoty pe (fragment a) of Culmitzschia florinii Ullrich 1964, x 1 (after Schuster, 1933, fig.6). 
Basionym: Lebachia mitis Florin 1939a, Palaeontographica, B 85, p.94.

Holotype: The specimen figured by Florin (1939a, plate XLIX/L, 7-8).

Culmitzschia mucronata (Florin) nov. comb.

Basionym: Lebachia mucronata Florin 1939b, Palaeontographica, B 85, p.124.

Holotype: The specimen figured by Florin (1939b, plate LXXV/LXXVI, 1-2).

Culmitzschia speciosa (Florin) nov. comb.

Basionym: Lebachia speciosa Florin 1939a, Palaeontographica, B 85, p.113.

Holotype: The specimen figured by Florin (1939a, plate LXV/LXVI, 6-7).

\section{PHYLOGENETIC CONSIDERATIONS}

General phylogenetic considerations on conifers are invariously based on the interpretation of the organization of the reproductive organs. It is here believed that the present concept of the earliest conifers known, the Walchiaceae, will certainly affect the conventional views on conifer phylogeny. Therefore, the relationship of this family with other extinct and extant conifers needs careful reconsideration. This also applies to the relation with the Cordaitales, frequently (after Florin, 1944b) regarded as the ancestral stock of the conifers. In the following paragraphs the consequences of the present interpretation of the Walchiaceae will be briefly discussed.

\section{Ouuliferous cones}

In the course of the investigation of coniferous ovuliferous cones during the last century, different opinions concerning their nature have been formulated. Some authors considered the ovuliferous cones to represent flowers (e.g. Pilger, 1926), others (e.g. Hagerup, 1933, on the basis of detailed ontogenetic studies) interpreted the cones as inflorescences. However, especially as a result of the work by Florin (1938-1945), it became generally accepted that ovuliferous cones are compound, the "seed-scales" representing transformed shoots of limited growth (ovuliferous dwarf-shoots) in the axils of bracts. For a survey of the various theories about the organization of ovuliferous cones, one is referred to the work of Pilger (1926), Florin (1954), Lam (1954) and Grauvogel-Stamm (1978).

In order to visualize the ancestry of extant conifers, Florin distinguished the following phylogenetic series: Cordaitales $\rightarrow$ Walchia ("Lebachia") $\rightarrow$ Pseudovoltzia $\rightarrow$ Glyptolepis $\rightarrow$ Voltzia $\rightarrow$ extant conifers (without Cephalotaxus). This phylogenetic chain became interrupted by Schweitzer (1963). By means of anatomical studies Schweitzer proved that Florin's interpretation of the "seed-scale" of Pseudovoltzia was not correct: the ovules are not stalked, but directly inserted on foliaceous megasporophylls. Also in other extinct genera (Ullmannia, Glyptolepis) Schweitzer did not establish the presence of stalked ovules; this would indicate the possibility of a direct insertion of the ovule on a foliaceous megasporophyll. Schweitzer accepted, however, Florin's concept of the stalked ovules in Walchia and Ernestiodendron. Consequently, he concluded that it is impossible to derive 
Pseudovoltzia from Walchia. He considered Pseudovoltzia to represent the first member of a new phylogenetic series, leaving a gap between the Early Permian conifer Walchia and the Late Permian Pseudovoltzia (compare Harris, 1976).

It should be noted, however, that, after the work of Schweitzer the presence of stalked ovules has been accepted in the reconstruction of the extinct conifers Voltziopsis (Townrow, 1967), Aethophyllum (GrauvogelStamm, 1978), Moyliostrobus (Miller and Brown, 1973). Also Rothwell's (1982) anatomical studies of Walchia cones follow Florin's concept.

Implications of the present concept. The present information on Ortiseia and the re-interpretation of the Walchiaceae fully confirms Florin's concept of the compound nature of the coniferous ovuliferous cones but is in contradiction with his concept of stalked ovules and his interpretation with regard to the number of ovules per dwarf-shoot within the Walchiaceae.

The present concept - the ovule of the Walchiaceae is invertedly inserted on the abaxial surface of a foliaceous megasporophyll - may also be readily applied to the interpretation of the organization of dwarf-shoots of other extinct and extant conifers. In Pseudovoltzia, for example, the fertile and sterile scales are connate and, as a result of the strongly flattened nature of the dwarf-shoot, arranged in one plane. The ovules are inserted near the bases of the fertile scales (Schweitzer, 1963) on the adaxial side of the dwarfshoot. Considering the position of the ovules in Ortiseia and Walchia, it seems a logical inference that also in Pseudovoltzia the position of the ovules can be interpreted in terms of an insertion on the abaxial surface of the megasporophylls. Moreover, the vascular bundles supplying the scales of the ovuliferous dwarf-shoot are inverted in Pseudovoltzia (Schweitzer, 1963), their xylem facing the xylem of the subtending bract. Thus, in Pseudovoltzia the abaxial surface of the megasporophyll is part of the adaxial side of the flattened dwarf-shoot.

A similar situation might be present in morphologically similar dwarfshoots of other extinct conifers, such as Glyptolepis, Voltzia, Voltziopsis, Aethophyllum and Moyliostrobus. This needs, however, further consideration because it should be remembered that Townrow (1967), GrauvogelStamm (1978) and Miller and Brown (1973) have given a different interpretation. The study on Moyliostrobus does not deliver clear evidence concerning the existence of stalked ovules; on the contrary, the present author presumes that the organization of dwarf-shoot and ovule might resemble that of Ortiseia. Also the anatomical studies of Miller and Brown (1973) concerning a Walchia ovuliferous cone do not provide evidence in this respect. It is interesting, however, that in contradiction to Florin, the authors described the dwarf-shoots to be clearly tangentially flattened, rather than radially in either morphology or anatomy. Moreover, according to Miller and Brown, the ovule does not exhibit a bifid micropylar region as described by Florin.

Following the new concept of the Walchiaceae, also in extremely reduced 
ovuliferous dwarf-shoots ("seed-scales") of the younger conifers, both extinct and extant, the seemingly adaxial position of ovules could well represent an original abaxial position.

Already in the nineteenth century the inverted position of the vascular bundles in "seed-scales" of extant conifers had been recognized. Before Florin introduced his concept of stalk-like megasporophylls, a number of botanists (A. Braun, 1842, cited in Pilger, 1926, p.128; Stenzel, 1876; Celakovský, 1890, 1900) indeed considered the "seed-scale" to represent axillary dwarf-shoots, reduced to fused "carpels", each bearing an ovule on its abaxial surface. Other authors, however, advocated an adaxial position (e.g. Hagerup, 1933).

Although the new concept to some degree bridges the gap between the Walchiaceae and Pseudovoltzia it seems an illogical inference to derive Pseudovoltzia directly from this family. An important difference is formed by the number of ovules per dwarf-shoot ( 3 and 1, respectively). More related to Pseudovoltzia (and other genera with several ovules per dwarfshoot) is perhaps a so far unnamed, Early Permian coniferous genus, represented by Florin's Walchiostrobus species with $3-8$ ovules per dwarf-shoot (see Florin, 1940, pp.261-269); a similar view is suggested by Meyen (1983).

Possible descendants of the Walchiaceae might be sought for in taxa, showing a single ovule per dwarf-shoot. Considering the fossil record one may find Ullmannia Göppert 1850 [Upper Permian; ovuliferous organs described by Florin $(1927,1951)$ as belonging to $U$. bronnii, by Schweitzer $(1962,1963)$ as belonging to $U$. frumentaria ], Ontheodendron Sahni et Rao 1933 (Jurassic), Drepanolepis Nathorst 1897 (Cretaceous), Araucariaceae (since Jurassic). Recent uniovular taxa are Araucariaceae and Podocarpaceae. It should be noted that some representatives of the Araucariaceae, both extinct and extant, show biovular cone scales (Wilde and Eames, 1955; Stockey, 1982). This should exclude a relationship with the Walchiaceae, though considering the frond there are similarities.

The ovuliferous dwarf-shoots of above-mentioned taxa are so modified by coalescence of scales and partial or complete fusion of bract and "seed scale" (resulting in a "cone scale"), that none can be derived directly from the Walchiaceae; it is still necessary to find transitional stages.

With respect to the ancestry of the Walchiaceae it can be noticed that, following the new concept, the strong resemblance Florin $(1944 \mathrm{~b}, \mathrm{p} .479)$ observed between the ovuliferous dwarf-shoots of the Cordaitales and Walchia becomes less apparent. Yet there are some conformities such as: (1) dwarf-shoots arising in bract axils, and provided with sterile scales; (2) nucellus free to its base; and (3) ovules with pollen/archegonial chamber (though in Florin's interpretation of the ovule of the Walchiaceae, they did not possess a pollen/archegonial chamber). In the Cordaitales the ovules are terminally attached on stalk-like, sometimes branched megasporophylls; in certain species (C. zeilleri) these megasporophylls are shorter, more foliaceous and bearing a single ovule. The terminal erect position of the ovule is in clear contrast with the inverted abaxial insertion in the Walchiaceae. 
It is here considered that, on the basis of the organization of the ovuliferous organs, the close relationship between the Cordaitales and the Walchiaceae as suggested by Florin, cannot be maintained. It is unlikely, therefore, that the Cordaitales represent the direct ancestors of the known coniferous stock.

With respect to the stalked ovules of Buriadia, described by Pant and Nautiyal (1967) from the Lower Gondwana deposits of India and regarded as possibly ancestral to the earliest conifers as Walchia and Ernestiodendron (Pant and Nautiyal, 1967; Pant 1982), it can be considered that the absence of stalked ovules in the Walchiaceae excludes a close relationship. Further the megaspore membrane is not cutinized in Buriadia, therefore even a coniferous affinity of Buriadia is disputable (see also Meyen, 1968).

With respect to the origin of the integument, the present author agrees with the essential point of Florin's concept $(1951$, p.339) that in Cordaitales and conifers the integument is single and formed by a direct outgrowth of the megasporophyll.

\section{Polliniferous cones}

In contrast to the ovuliferous cones the polliniferous cones of most extinct conifers give a rather modern impression. Although it is generally accepted that the polliniferous cone represents a simple strobilus, a historical review of the investigations of polliniferous cones reveals some discrepancies with respect to the basic form and the homology of the microsporophyll:

(1) The basic form of the microsporophyll is: (a) a leaf-like, dorsiventral and hyposporangiate differentiation (e.g., Pilger, 1926; Von Wettstein, 1935); (b) a radial, undifferentiated branched sporangial truss with terminal erect sporangia (e.g., Doyle, 1926; Zimmermann, 1959).

(2) The microsporophyll is homologous with: (a) an ovuliferous dwarfshoot, bracts in polliniferous cones have disappeared (e.g., Doyle, 1926); (b) a bract - this should explain the so-called androgynic cones (e.g., Chamberlain, 1935); (c) a dwarf-shoot plus its subtending bract-this should explain a sometimes homologous position of ovuliferous and polliniferous cones (e.g., Zimmerman, 1959); (d) a megasporophyll - this should explain that both micro- and megasporophyll bear their sporangia on their abaxial surfaces (Van Tieghem, 1869). In this concept the polliniferous cone is homologous with the ovuliferous dwarf-shoot (Wilde, 1944).

The new concept. The present information on Ortiseia delivers no new aspects about the morphological organization of polliniferous cones of Palaeozoic conifers. Concerning the first controversy - the basic form of the microsporophyll - no new ideas could be formulated.

Something more can be said about the question of the homologies. The new concept - in both extinct and extant conifers the ovule is inserted on the abaxial surface of a megasporophyll - fully agrees with the usually abaxial insertion of the pollen sacs. Therefore, it may logically be considered 
that the microsporophylls are homologous with the megasporophylls. Following this line of thought, the polliniferous cone is homologous with a single ovuliferous dwarf-shoot.

This homology has already been elaborated by Wilde (1944) in a study on fructifications of Podocarpaceae. Within this family one may find complex male fertile branching systems, single terminal cones, as well as a number of transitional organizations of male fructifications. For correlating the simple polliniferous cone with the compound ovuliferous cone, she considered the single terminal polliniferous cone as a remain of a more complex male branching system in which the lateral cones have disappeared. In the Walchiaceae, at least in Walchia and Ernestiodendron, the ovuliferous cones are placed terminally on lateral axes of penultimate or ultimate order (Walchia hypnoides, Ernestiodendron; Walchia piniformis respectively). The polliniferous cones are always placed terminally on branches of the ultimate order. The position of the cones in Ortiseia is so far unknown. When applying Wildes's concept to the Walchiaceae, it should be noted that in the Palaeozoic conifers the reduction of the male branch system would be more progressed than in some extant conifers.

Remarkable, concerning this subject, is a hypothesis of Celakovský $(1890$, p.98) which is quite the opposite to that of Wilde: the ancestors of the conifers bore both polliniferous and ovuliferous "flowers" terminally on an axis; the polliniferous "flower" maintained the terminal position, in contrast to the ovuliferous "flower". Here, the terminal "flower" disappeared (was suppressed), causing the development of other "flowers", in axils of leaves of the "flower"-bearing axis (= other ovuliferous dwarf-shoots in the bract axils). Though Celakovský did not involve fossil material in his phylogenetic considerations, his hypothesis is not in contradiction with the (later) investigations on fossil conifers and even Cordaitales (here the polliniferous strobilus in terminal position should be suppressed, causing the typical male inflorescences). The present author considers this hypothesis to be more suitable to explain the position of polliniferous and ovuliferous cones within the Walchiaceae than Wilde's hypothesis.

It should be noted that acceptance of Celakovsky's hypothesis would imply that the microsporophyll is not only homologous with the megasporophyll, but also with the bract.

Examination of the polliniferous cones of the Walchiaceae reveals no important information concerning possible descendants. The terminal attachment of the cones can be found in other extinct and extant conifers. Also with respect to their morphological organization the cones of the Walchiaceae have much in common with other extinct and extant conifers.

The polliniferous cones of the Walchiaceae differ greatly from those of the Cordaitales. Even when assuming that the polliniferous cones of the Walchiaceae may represent relicts of male inflorescences (Wilde, 1944), there is an obvious difference in organization and situation of the microsporophylls. Although spirally inserted in both groups, the microsporophylls of the Cordaitales are intermixed with sterile scales and bear terminally erect pollen sacs. 
With respect to the pollen it can be noticed that there certainly exist similarities between the Walchiaceae and Cordaitales. According to Millay and Taylor (1974) at least part of the monosaccate pollen of the Cordaitales represent in effect prepollen. The presence of prepollen, however, cannot be interpreted as an argument in favour of a cordaitalean ancestry for the Walchiaceae.

\section{CONCLUDING REMARKS}

The Late Permian coniferous genus Ortiseia, originally described as a form-genus based on vegetative remains and epidermal structure, has been "promoted" to a natural genus by completing its diagnosis with descriptions of the ovuliferous and polliniferous organs. Up to now in the Val Gardena Formation of the Southern Alps three species can be distinguished: $O$. leonardii, $O$. visscheri nov. sp., and $O$. jonkeri nov. sp.

In the light of the knowledge of primitive conifers, notably the organization of the compound ovuliferous cone of Ortiseia appears to be of considerable importance. It is shown that the ovuliferous dwarf-shoots are flattened and composed of 20-30 sterile scales and a single megasporophyll, bearing one inverted ovule on its abaxial surface. The pollen grains, corresponding to the palynological form-genus Nuskoisporites, show all characteristics of prepollen (proximal trilete aperture, absence of distal germinal area, large size).

Comparing the genus Ortiseia with other Permian coniferous genera, it is established that there are great differences with the coeval genera Ullmannia and Pseudovoltzia. On the other hand, an obvious resemblance exists between Ortiseia and the Late Carboniferous/Early Permian genera Walchia (synonym: Lebachia) and Ernestiodendron. It appeared that the generally accepted concept of Florin concerning the organization of the ovuliferous cones of these genera is by no means indisputable. There exists considerable evidence that the ovuliferous dwarf-shoots of Walchia and Ernestiodendron are not characterized by the presence of stalked ovules but show an organization comparable to that in Ortiseia. On a suprageneric level the three genera can be readily classified within the same family, the Walchiaceae (synonym: Lebachiaceae). Within the Walchiaceae the form-genus Culmitzschia can be retained as a suitable taxon for accommodating species based exclusively on vegetative remains with epidermal structure. The species $C$. florinii may represent vegetative remains of Ortiseia that cannot be assigned to a natural species.

Considering the position of the ovule in Ortiseia and Walchia, it seems a logical inference that also in other extinct and extant conifers the position of the ovules can be interpreted in terms of an insertion on the abaxial surface of the megasporophylls. This suggestion is supported by the inverted position of the vascular bundles, supplying the dwarf-shoot and the subtending bract. Moreover, the position of ovules and pollen sacs is in agreement, both organs being inserted on the abaxial surface of a sporophyll. 
The close relationship between the Cordaitales and the Walchiaceae, as suggested by Florin, cannot be maintained. The terminal erect position of the ovule is in clear contrast with the inverted abaxial insertion in the Walchiaceae.

With respect to possible descendants of the Walchiaceae it can be stated that no taxon can be directly derived from this family.

The assumption of some authors that supposedly "mixed" (Walchia, Ullmannia) floras from the Val Gardena Formation would represent (at least partly) a Middle Permian ("Saxonian") age is not justified. The plant remains, formerly identified as Walchia or Lebachia probably belong to Ortiseia, notably 0 . jonkeri.

The presence of Culmitzschia and the frequent occurrence of Nuskoisporites throughout the West European Upper Permian, indicate the presence of conifers, closely related or perhaps belonging to the genus Ortiseia in outer Alpine Late Permian deposits. A revision of the flora of the Zechstein and lateral equivalents is needed to more fully establish the areal extent of Late Permian representatives of the Walchiaceae.

\section{ACKNOWLEDGEMENTS}

The author is greatly indebted to Prof. Dr. H. Visscher, originator of the present investigations in the Alpine Permian, for his inspiring and essential supervision and support. Further I wish to thank Prof. Dr. F.P. Jonker for his stimulating interest with respect to my investigations and his valuable and constructive criticism during the course of the investigation. The extensive written comments by the late Prof. Dr. T.M. Harris will be kept as a precious document. My very special gratitude goes to Mr. M. Clement for his everlasting interest, encouragement, patience and support during my investigations and several collection excursions. Grateful appreciation is rendered to Dr. J. van der Burgh, Dr. J.H.A. van Konijnenburg-Van Cittert and Drs. J.H.F. Kerp for the fruitful discussions and comments in the course of the present study. Many thanks are also due to Dr. M. Boersma, Dr. A.W. van Erve, Dr. W.M.L. Schuurman, Dr. J.G.L.A. van der Eem, Dr. C.J. van der Zwan, Drs. J.J. Klasen and Drs. W.A. Brugman for their valuable and essential aid in tracing and collecting the "weighty" material in the Southern Alps. My sincerest thanks to Dr. B. Lundblad (Stockholm) and Mr. K. Baum (Sobernheim) for the opportunity to borrow slides with Walchia and Ernestiodendron cuticles and an ovuliferous dwarf-shoot assignable to Walchia, respectively. My thanks also to the Gësa di Ladin's Museum in Ortisei for the opportunity to study and photograph the holotype of Ortiseia leonardii. I am most grateful to Dr. W. Punt and Dr. W. Berendsen for their assistance with the SEM investigations. Many thanks to Mr. A. Elmont for chemical support, Mr. H.A. Elsendoorn for preparing the photographs, to Mr. H. Rypkema, who made the drawings and to Mrs. G. van der Linde for typing Tables I-III. The author is greatly indebted to the Netherlands Organization of Pure Research (Z.W.O.) for the initial financial 
support during this study (1972--1974). One of the collection excursions (1974) was supported by a grant from the Catharina van Tussenbroek Fund (Dutch Federation of University Women).

PLATE I (p. 123)

Ortiseia leonardii

1. Holotype (specimen $1 / \mathrm{mO} ;$ Cuecenes): $\mathrm{a}, \times 0.22 ; \mathrm{b}$, detail, $\times 0.65$.

PLATE II (p. 124)

Ortiseia leonardii: shoots and cones

1. Shoot penultimate order, $\times 1.75$ (specimen 14101; Butterloch R4).

2. Shoot ultimate order, $\times 1.75$ (specimen 14102; Butterloch R4).

3. Shoot ultimate order, $\times 1.75$ (specimen 14103; Butterloch R 78).

4. Ovuliferous cone, $\times 1.75$ (specimen 14104, Cuecenes), original to Fig. 3 .

5. Polliniferous cone, $\times 1.75$ (specimen 14105, Butterloch R4).

PLATE III (p. 125)

Ortiseia leonardii: main axis, leaf main axis and leaf penultimate order

1. Leaf main axis (prep. 545; Taubenleck RTD): a, detail, on the left abaxial surface showing apical stomata-free zone, on the right the (incomplete) adaxial surface, $x$ 4.35 ; b, detail, on the left abaxial, on the right adaxial surface, marginal stomatafree zones visible, $\times 26$; $c$, detail of central part of abaxial surface, showing stomatal complexes and papillae, $X 130$.

2. Main axis, epidermal structure, $\times 130$ (prep. 546; Butterloch R4).

3. Leaf penultimate order, $\times 4.35$ (prep. $551 \mathrm{~b}$; Butterloch R4).

PLATE IV (p. 126)

Ortiseia leonardii: leaves originating from the same penultimate shoot

1. Leaf penultimate order, basal part, $x 11$ (prep. 552a; Butterloch R4): a, abaxial surface; $b$, adaxial surface.

2. Leaf penultimate order, abaxial surface, same specimen as figured on Plate III, 3 (prep. 551b; Butterloch R4): a, apical part, $x$ 11; b, central part, note epidermal papillae and hair-bases, $\times 130$; c, detail, showing stomatal complex with subsidiary cells ornamented with papillae, $\times 650$.

3. Leaf penultimate order, adaxial surface, apical part, $\times 11$ (prep. 551c; Butterloch R4).

PLATE V(p. 127)

Ortiseia leonardii: leaves penultimate order, axis ultimate order, leaves ultimate order

1. Leaf penultimate order, same specimen as figured on Plate IV, 3, detail central part adaxial surface showing doubled stomatal rows, $\times 130$ (prep. 551c; Butterloch R4).

2. Leaf penultimate order, same specimen as figured on Plate III, 3, detail abaxial surface, showing stomatal complex and epidermal papillae, $x 350$ (prep. 551b; Butterloch R4).

3. Leaf ultimate order, on the left adaxial, on the right abaxial surface, $\times 4.35$ (prep. 562; Butterloch R4).

4. Axis ultimate order, $\times 4.35$ (prep. 572 ; Butterloch R3b).

5. Leaves ultimate order, $\times 4.35$ (prep. 559; Taubenleck RTD).

6. Leaf ultimate order, apical part, $\times 26$ (prep. 555; Butterloch R2): a, abaxial surface; $b$, adaxial surface. 
PLATE I

Description on p. 122
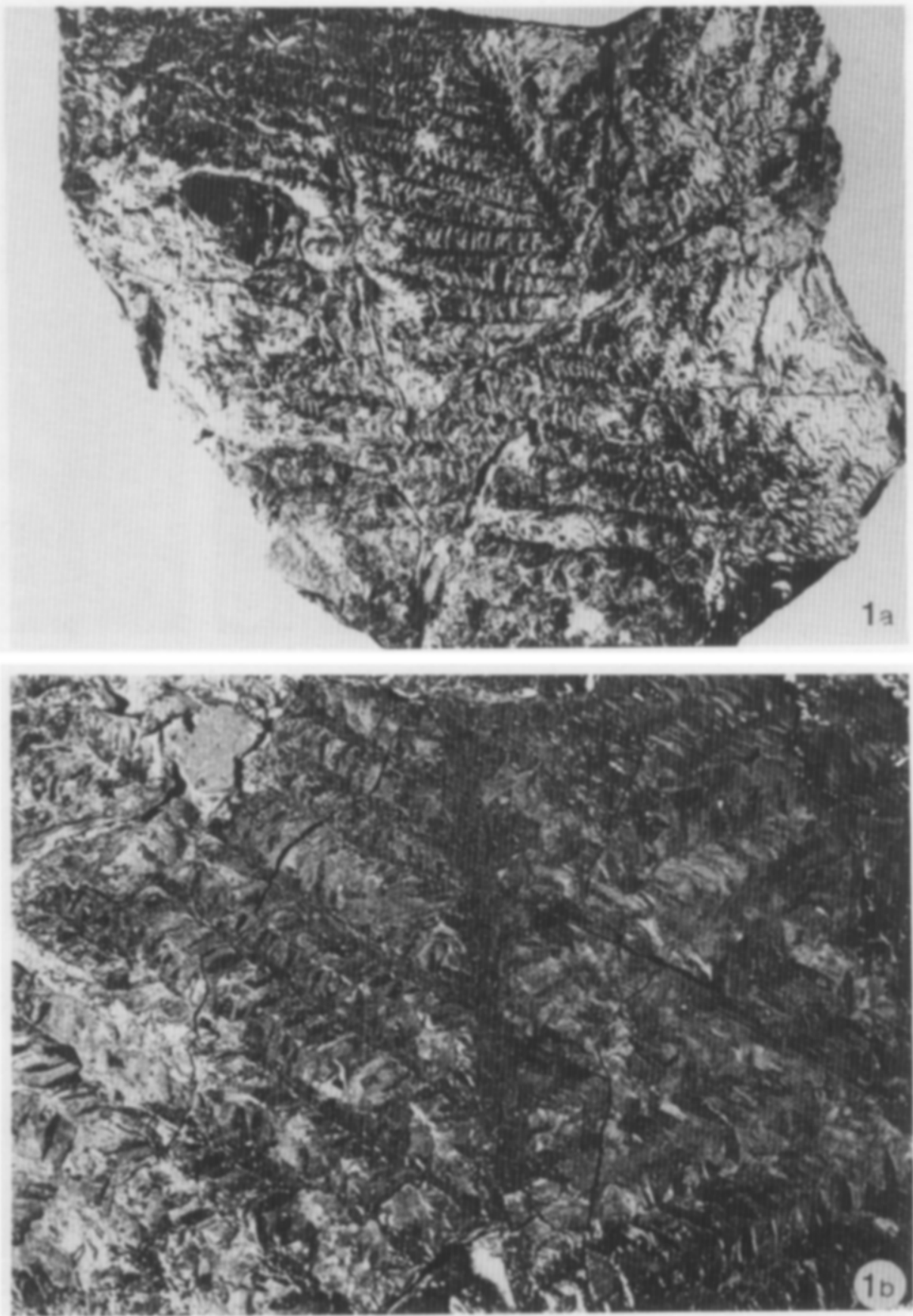
PLATE II

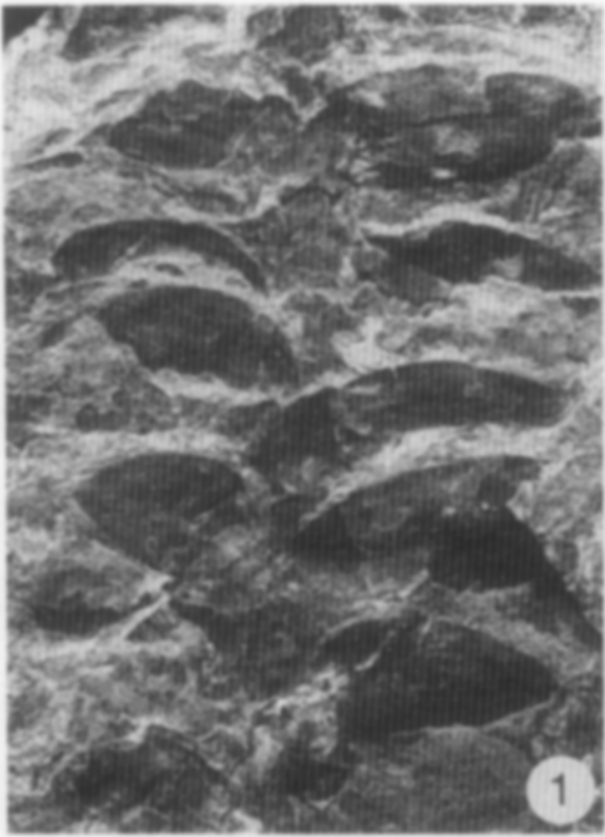

Description on p. 122
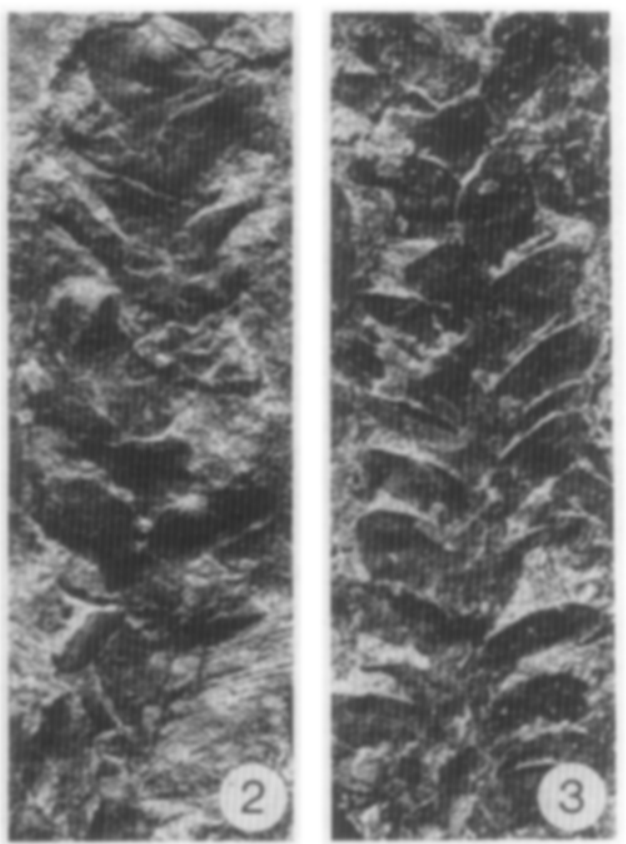
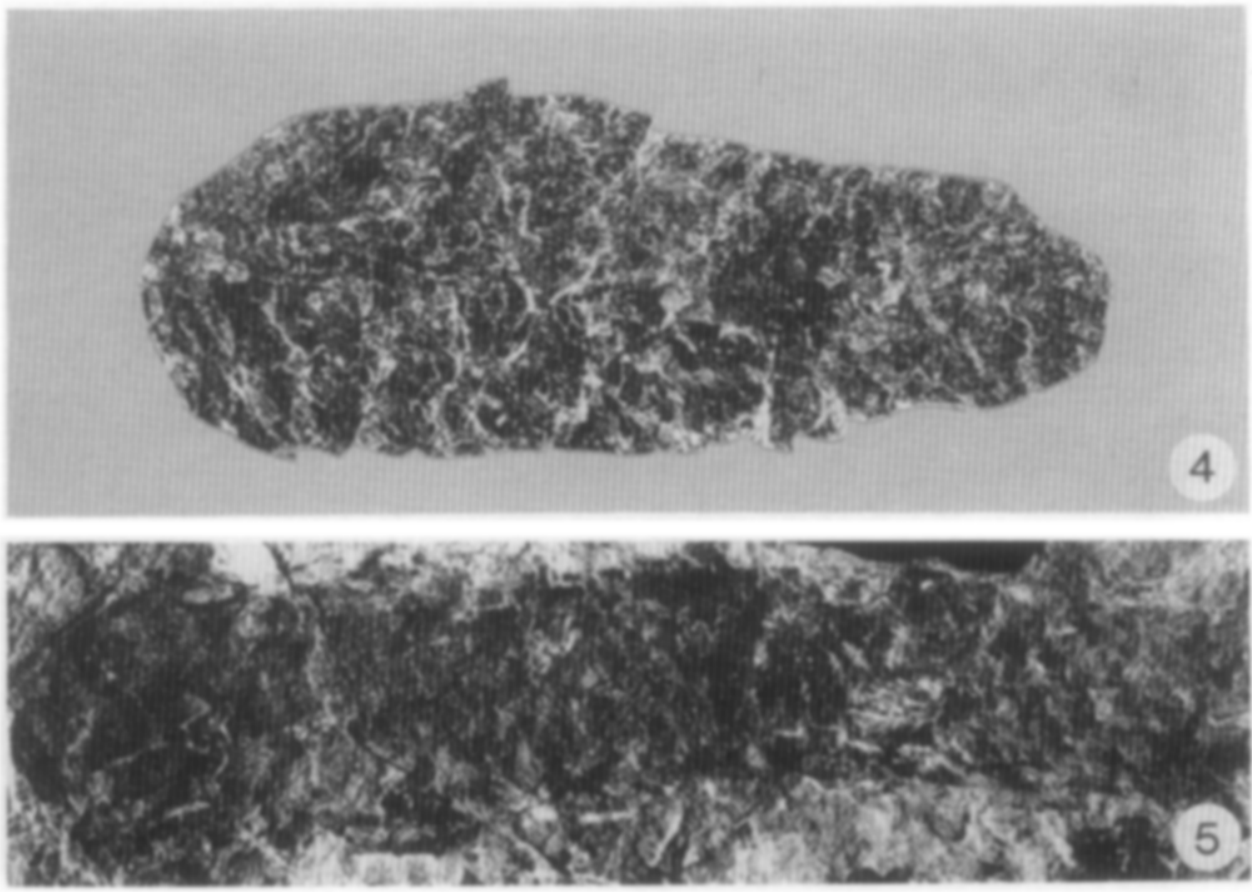
PLATE III
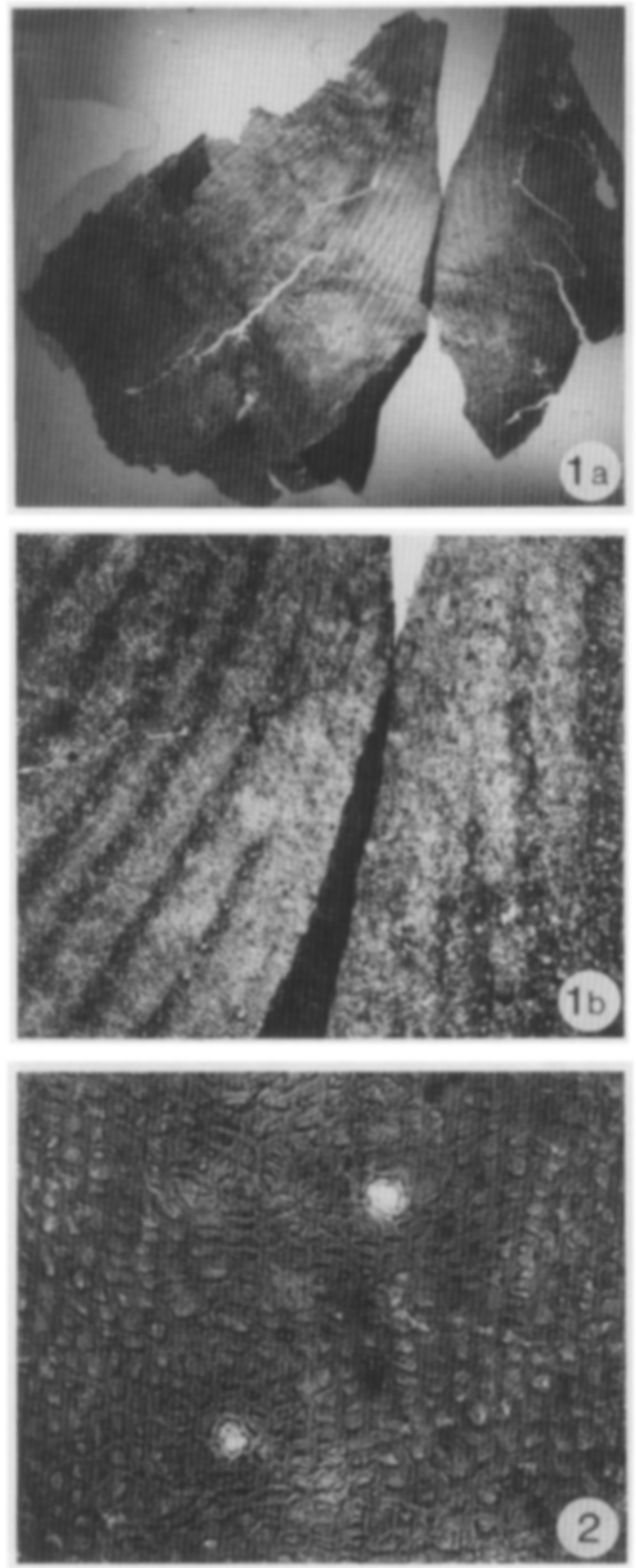

Description on p. 122
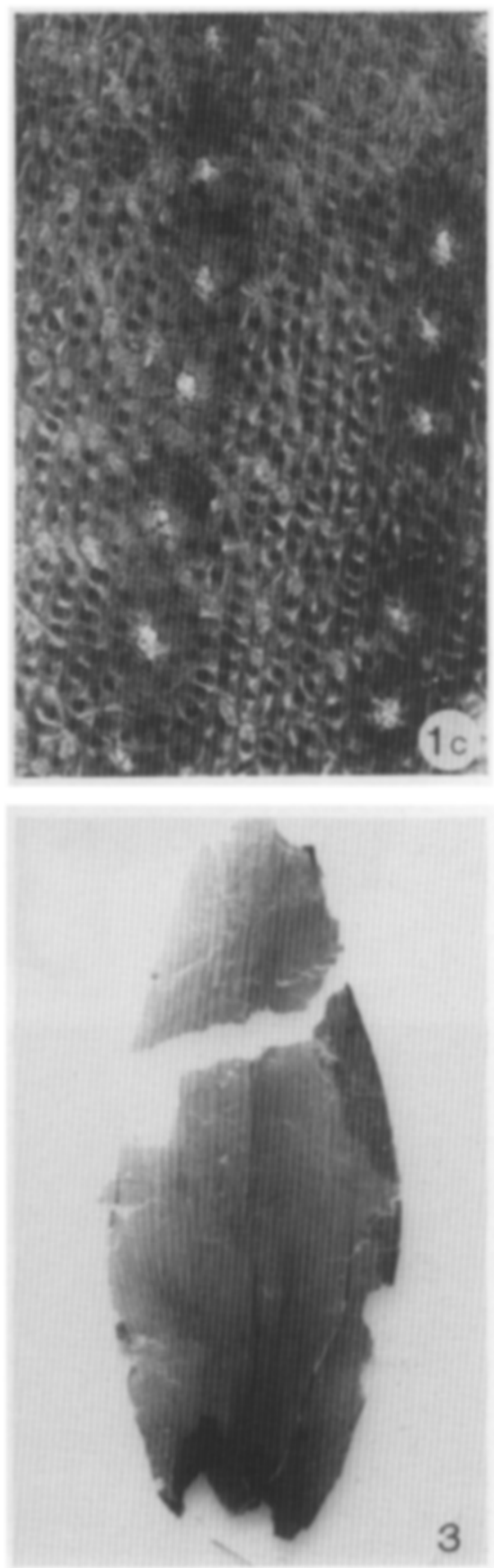
PLATE IV
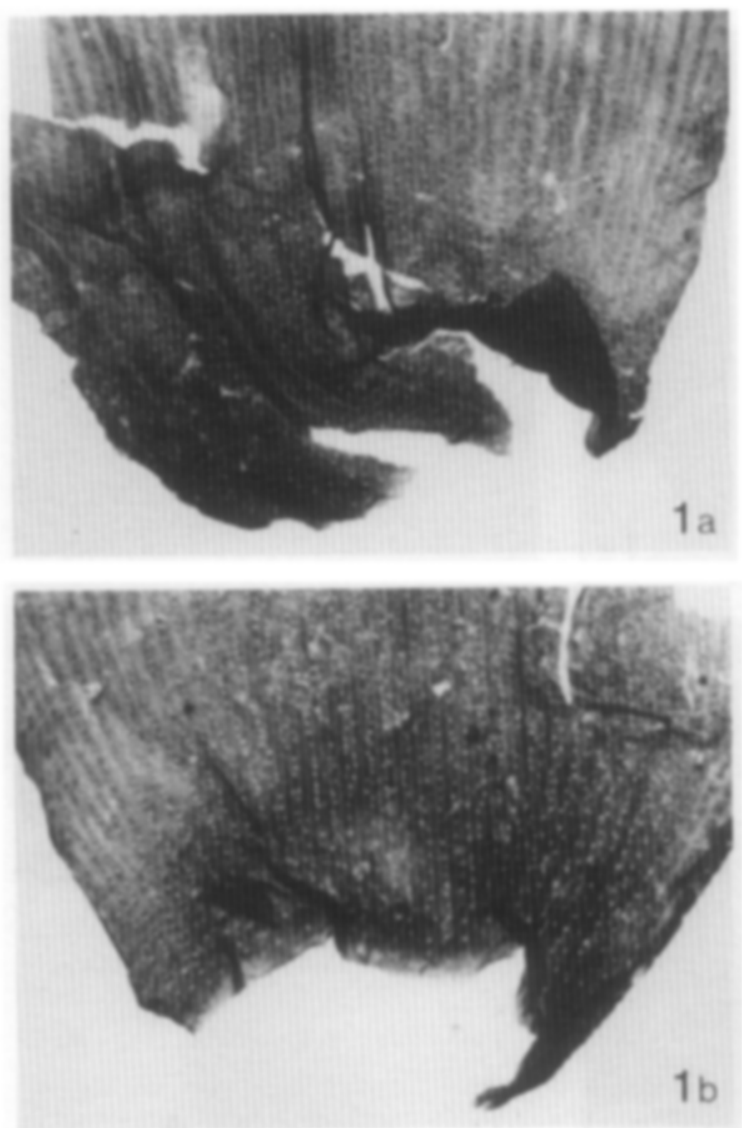

Description on p. 122
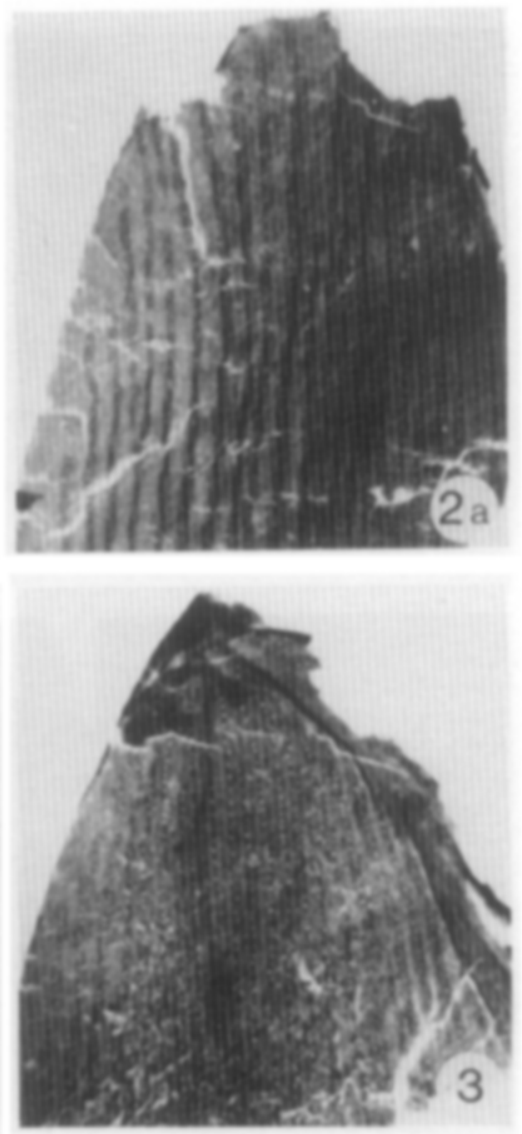
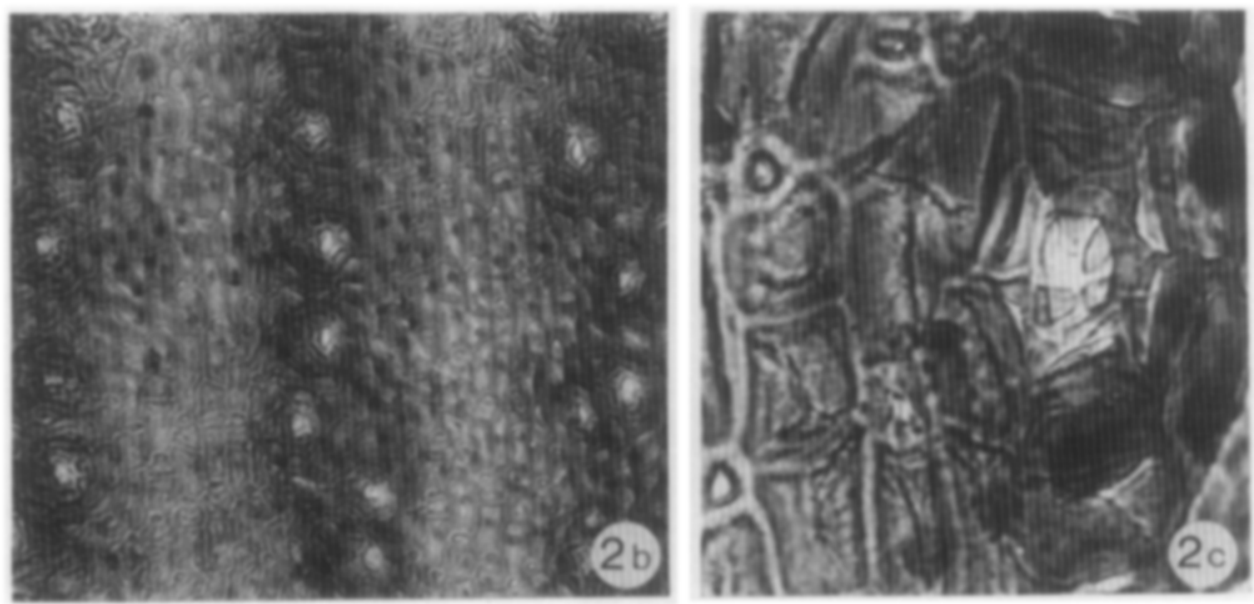


\section{PLATE V}

Description on p. 122
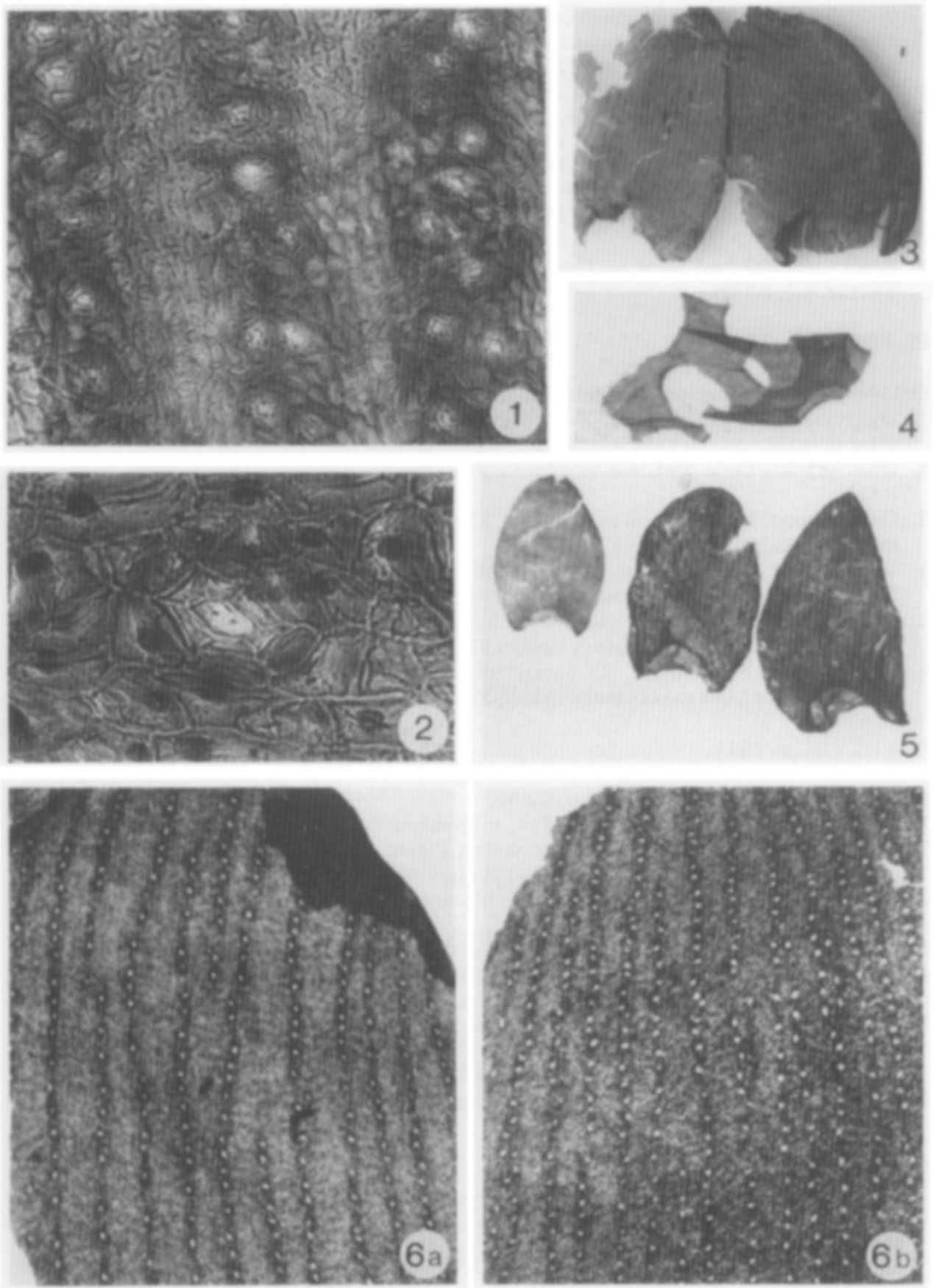
PLATE VI (p. 129)

Ortiseia leonardii: leaf ultimate order and bracts

1. Leaf ultimate order, epidermal structure, $\times 130$ (prep. 569 ; Butterloch R1): a, abaxial surface; $b$, adaxial surface, note adjacent stomatal complexes.

2. Bract (prep. 580e, originating from cone-fragment specimen $\mathrm{nr}$. 14128; Butterloch R2): a, on the left abaxial, on the right adaxial surface, note stomata-free zones, $x$ $11 ; b$, detail, central part of abaxial surface, showing crowded stomatal rows and stomatal complexes, sharing encircling cells, $\times 130$.

3. Bract, on the left abaxial, on the right adaxial surface, note stomata-free lower part of adaxial surface, $\times 11$ (prep. $581 \mathrm{~b}$, originating from cone, specimen 14129 ; Butterloch R4).

4. Bract, stomata-free basal part partly showing area of attachment, $\times 4.35$ (prep. 585 ; Taubenleck RTD).

PLATE VII(p. 130)

Ortiseia leonardii: fragments of ovuliferous dwarf-shoots

1. Dwarfshoot, basal part (prep. 586; Taubenleck RTD): a, before preparation, $x 11$; after preparation, on the right detached abaxial side, $\times 4.35$; $\mathrm{c}$, see Fig. $4 \mathrm{a}, \times 11$.

2. Dwarf-shoot, basal part, see explanatory sketch Fig.4b, $\times 11$ (prep. 600a; Butterloch R4).

3. Dwarf-shoot, basal part of abaxial side, $\times 11$ (prep. 581q, originating from cone, specimen 14129; Butterloch R4).

4. Dwarf-shoot, fragments, $\times 11$ (prep. $581 \mathrm{~m}$, originating from cone, specimen 14129 ; Butterloch R4): a, see explanatory sketch Fig.4d; b, see explanatory sketch Fig.4e.

5. Dwarf-shoot, fragment, $\times 11$ (prep. 581r, originating from cone, specimen 14129; Butterloch R4), see explanatory sketch Fig.4c.

6. Dwarf-shoot, fragment, $\times 11$ (prep. 581e, originating from cone, specimen 14129; Butterloch R4), see explanatory sketch Fig.4f.

PLATE VIII (p. 131)

Ortiseia leonardii, ovuliferous dwarf-shoots

1. Dwarf-shoot, apical part (prep. 581n, originating from cone, specimen 14129; Butterloch R4): a, $\times 11$, see explanatory sketch Fig.4g; b, detail epidermal structure, showing papillae (both on epidermal and subsidiary cells) and hair bases, $X 130$.

2. Dwarf-shoot, apical part, showing fertile scale, $\times 11$ (prep. 581g, originating from cone, specimen 14129; Butterloch R4).

3. Dwarf-shoot, apical part, showing fertile scale, $\times 11$ (prep. 589; Taubenleck RTA).

4. Dwarf-shoot, apical part, $\times 11$ (prep. $580 \mathrm{~h}$, originating from cone, specimen 14128; Butterloch R2), see explanatory sketch Fig.4h.

5. Dwarf-shoot with ovule detached, on the left basal part of ovule, showing a lateral and median extension, on the right the dwarf-shoot, $X 4.35$ (prep. 580h, originating from cone, specimen 14128; Butterloch R2).

6. Dwarf-shoot, epidermal structure, showing hairs and epidermal papillae: $a, \times 260 ; b$, $\times 435$. 
PLATE VI
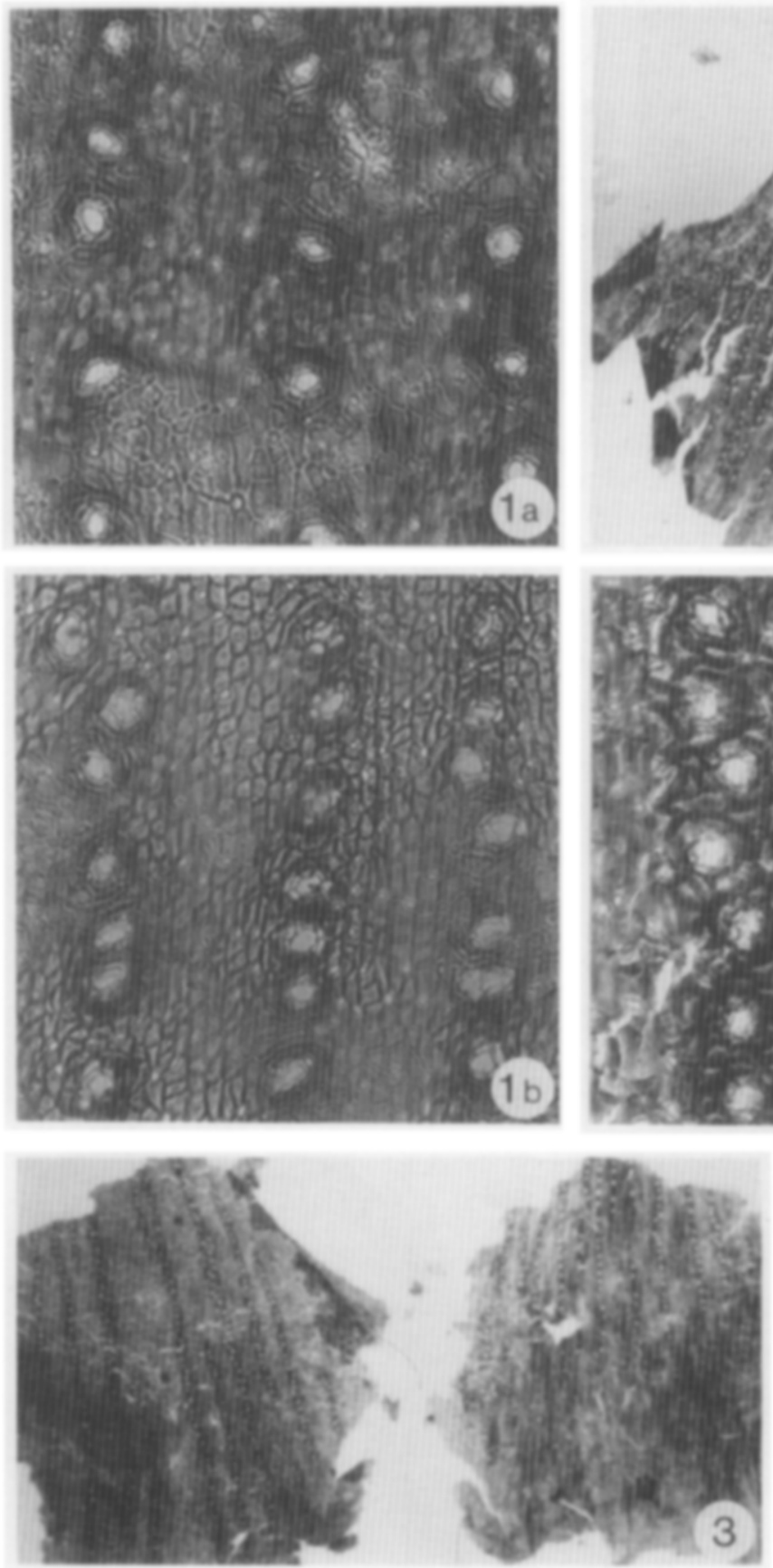

Description on p. 128
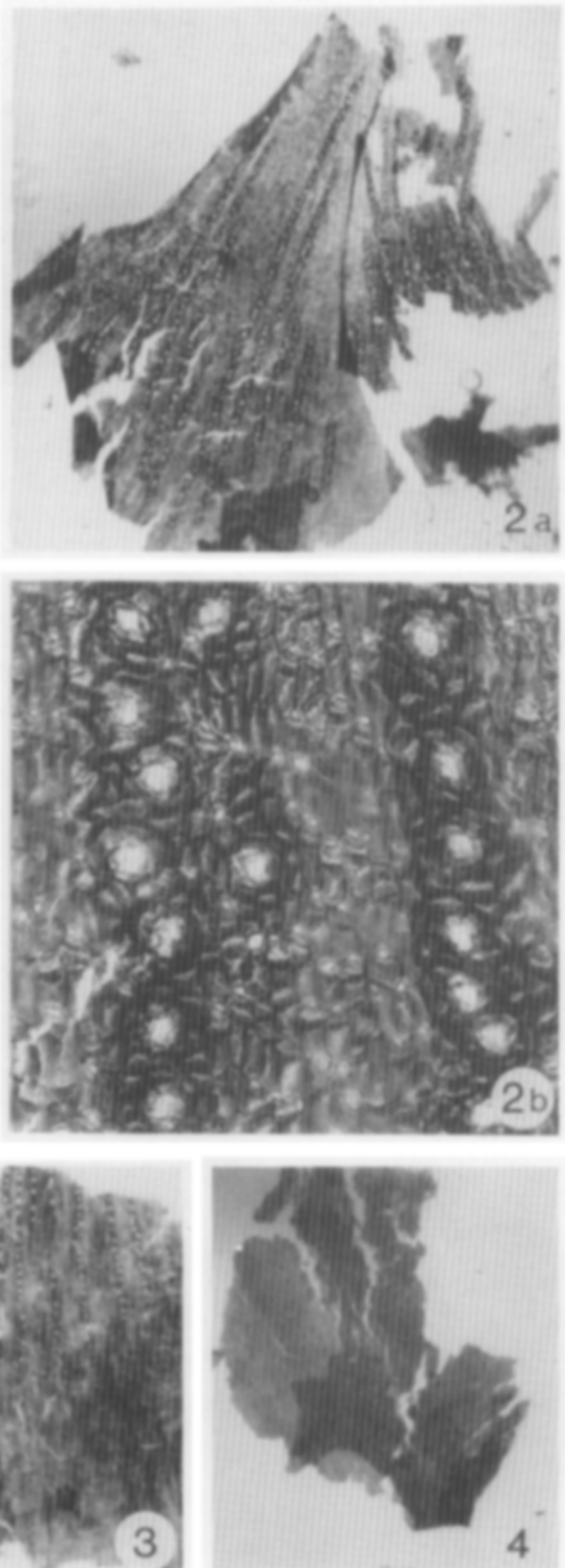
PLATE VII
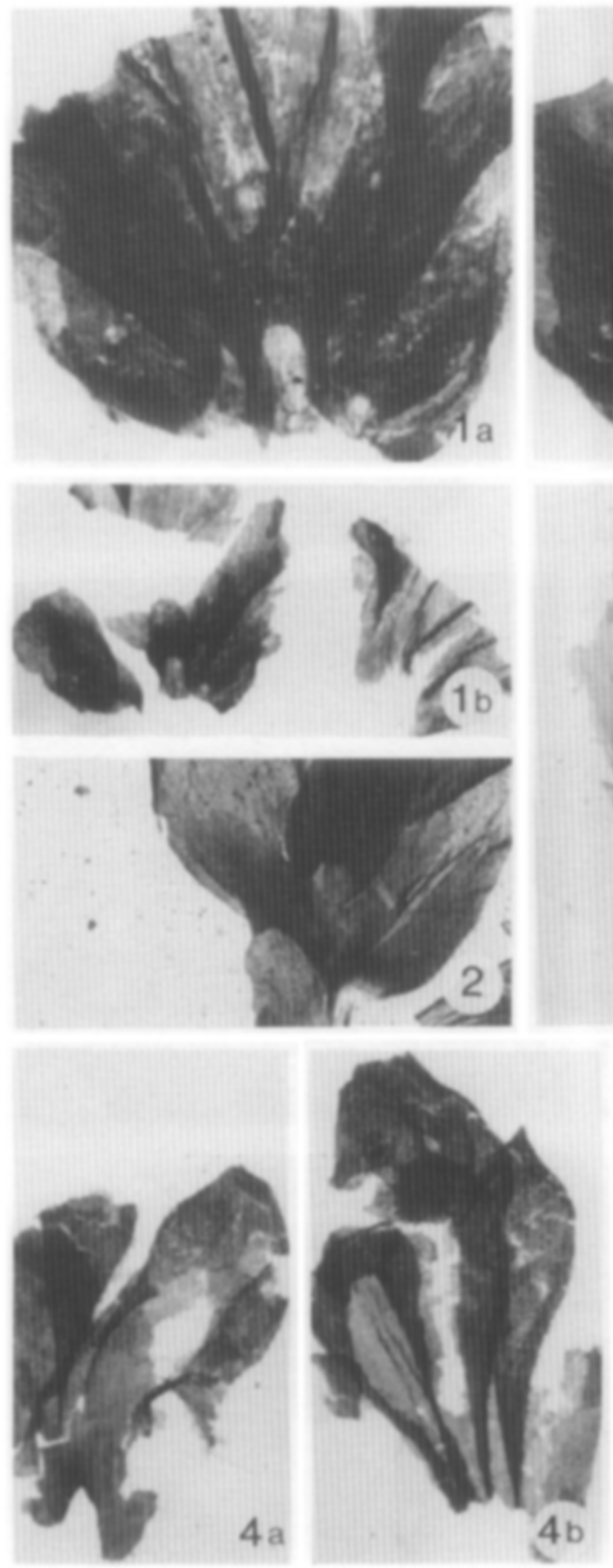

Description on p. 128
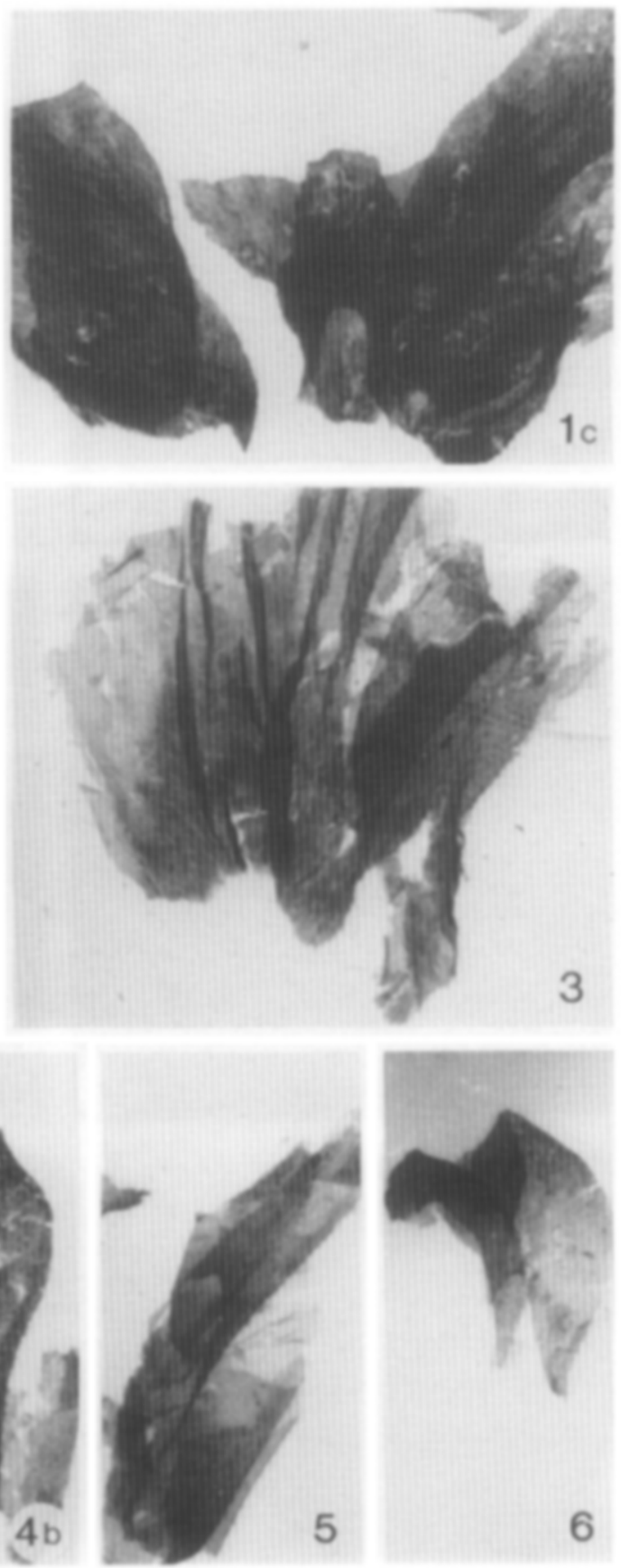
PLATE VIII
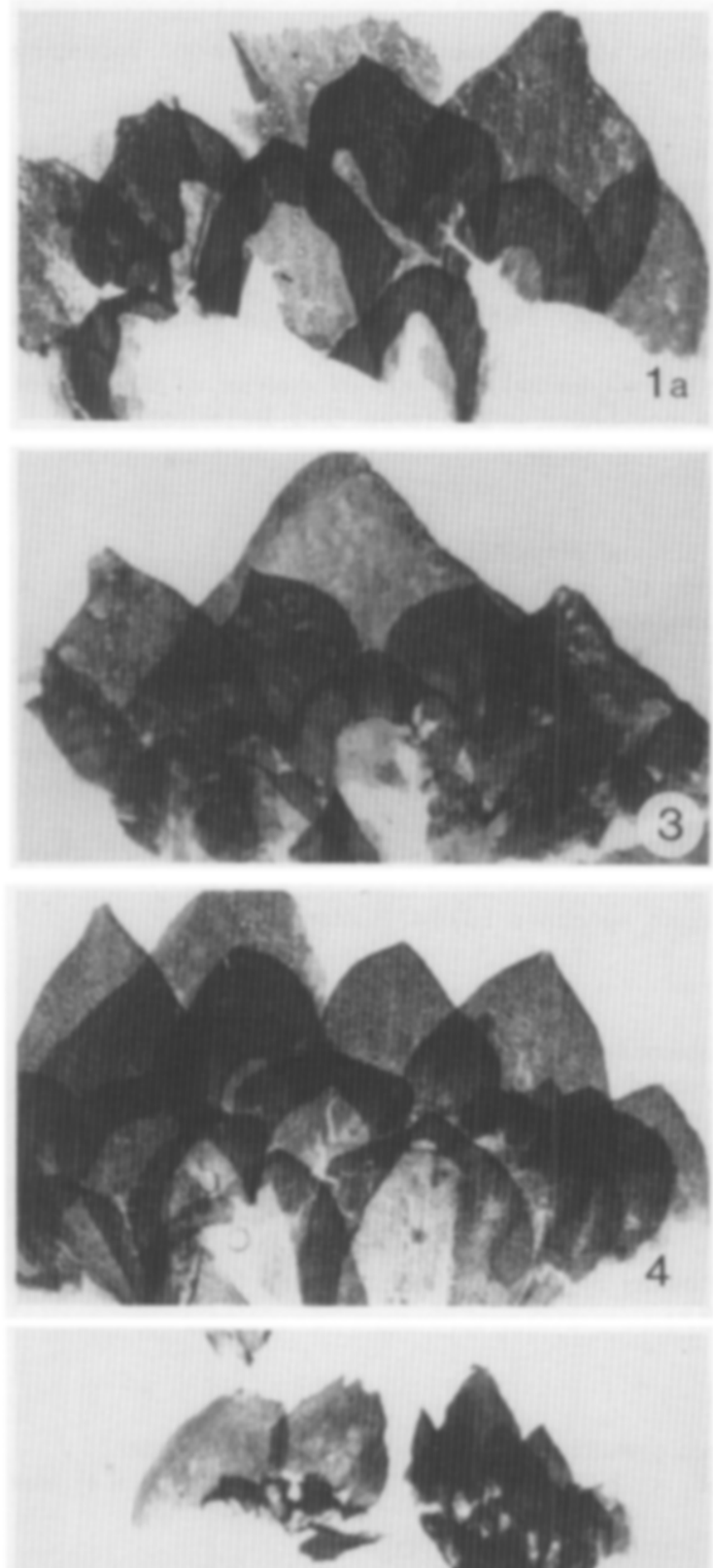

a.

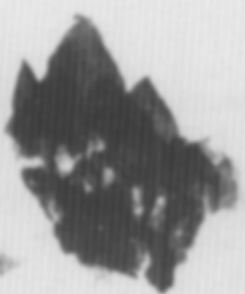

Description on p. 128
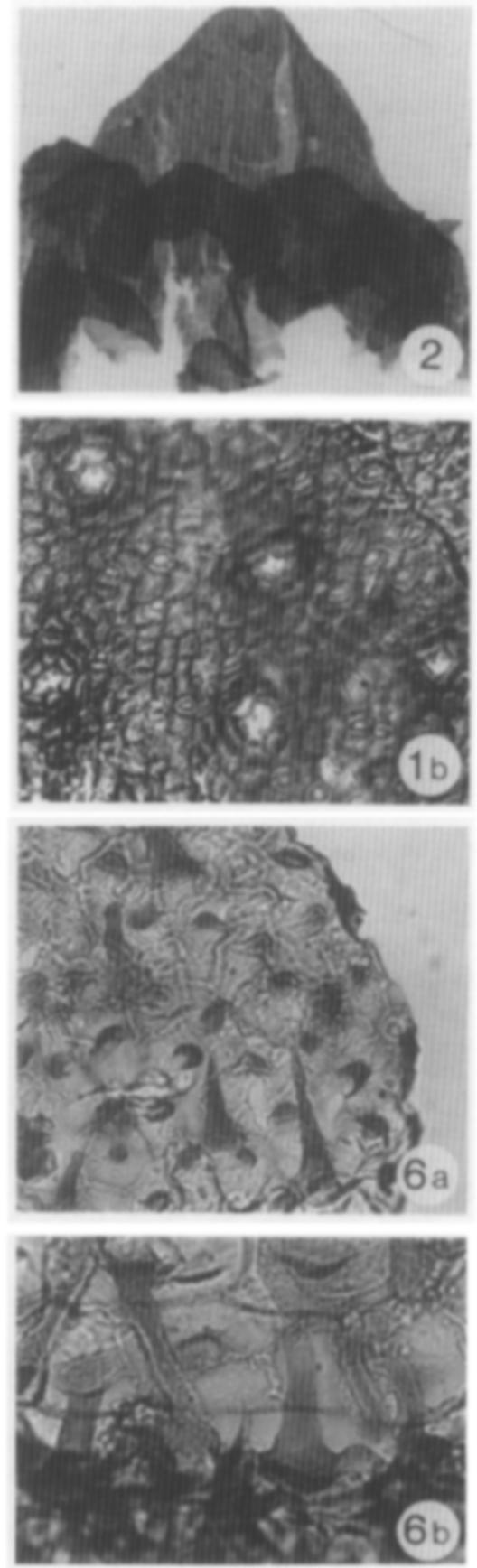
PLATE IX (p. 133)

Ortiseia leonardii: ovules/seeds

1. Seed, reverse aspect, before preparation; after preparation, the dwarf-shoot, belonging to it (Plate VII, 2) became visible, $\times 6$ (preps. 600a, b; Butterloch R4).

2. Seed, reverse aspect, $\times 4.35$ (specimen 14106; Butterloch R4).

3. Ovule, apical part, showing nucellus, megaspore and micropylar canal, $\times 11$ (prep. 581 a, originating from cone, specimen 14128 ; Butterloch R2).

4. Seed, basal part, showing integumentary extensions, note stomatal complexes on the right, $\times 11$ (prep. 588; Butterloch R4).

5. Ovule, apical part, showing on the left nucellus with micropylar canal, on the right cuticle of exterior of integument, $\times 26$ (prep. 581j, originating from cone, specimen 14129; Butterloch R4).

6. Seed, detail inner structure; on the left epidermal structure of interior of integument and nucellus, on the right megaspore membrane, $\times 130$ (prep. 582; Butterloch R4).

PLATE X (p. 134)

Ortiseia leonardii: ovule, microsporophylls and prepollen

1. Ovule, detail central part of exterior of integument, showing stomatal complex, $x$ 130 (prep. 581i, originating from cone, specimen 14129; Butterloch R4).

2. Microsporophyll, distal part, $\times 11$ (prep. 593a, originating from cone fragment, specimen 14131; Taubenleck RTdisp. 5).

3. Microsporophyll, distal part (prep. 591b, originating from cone, specimen 14114; Butterloch R4): a, apex, on the left abaxial, on the right adaxial surface, note stomatafree zones, $\times 26$; b, detail of central part of abaxial surface, showing epidermal structure, $\times 130$.

4. Microsporophyll, basal part of abaxial surface, showing stomata-free area, $\times 26$ (prep. 592; Butterloch R4).

5. Prepollen, $\times 130$ (originating from cone, specimen 14114; Butterloch R4).

PLATE XI (p. 135)

Ortiseia leonardii: cuticle of leaf ultimate order and ovuliferous dwarf-shoot (SEM)

1. Leaf ultimate order, exterior of cuticle of abaxial surface, showing stomatal complexes, papillae both on subsidiary and epidermal cells and hair bases (Butterloch R4): $a, \times 175 ; b$, detail, note hair-base, $\times 870$.

2. Same leaf, interior of cuticle, showing stomatal complexes and hair bases (visible as small circles, compare larger circles on exterior): $a, \times 175 ; b$, detail, $\times 870$, compare Fig.2a.

3. Dwarf-shoot, exterior of cuticle, showing papillae and hairs, $\times 260$ (originating from cone, specimen 14128; Butterloch R2).

PLATE XII (p. 136)

Ortiseia visscheri: leaves main axis, shoot penultimate order, shoots ultimate order

1. Shoot penultimate order, holotype, $x 1.75$ (specimen 14107; Butterloch R4), see explanatory sketch Fig.6.

2. Shoot ultimate order, $\times 1.75$ (prep. 620; Taubenleck RTD).

3. Leaf main axis, showing large area of attachment, $\times 4.35$ (prep. 605; Taubenleck RTB).

4. Leaf main axis (prep. 607 ; Butterloch R2): a, base abaxial surface, showing crowded stomatal complexes, $\times 26 ; b$, base adaxial surface, showing stomatal complexes in distinct rows, note wide marginal stomata-free zone, $\times 26$; c, detail apical part of abaxial surface, showing thick cell walls, $\times 130$. 
PLATE IX
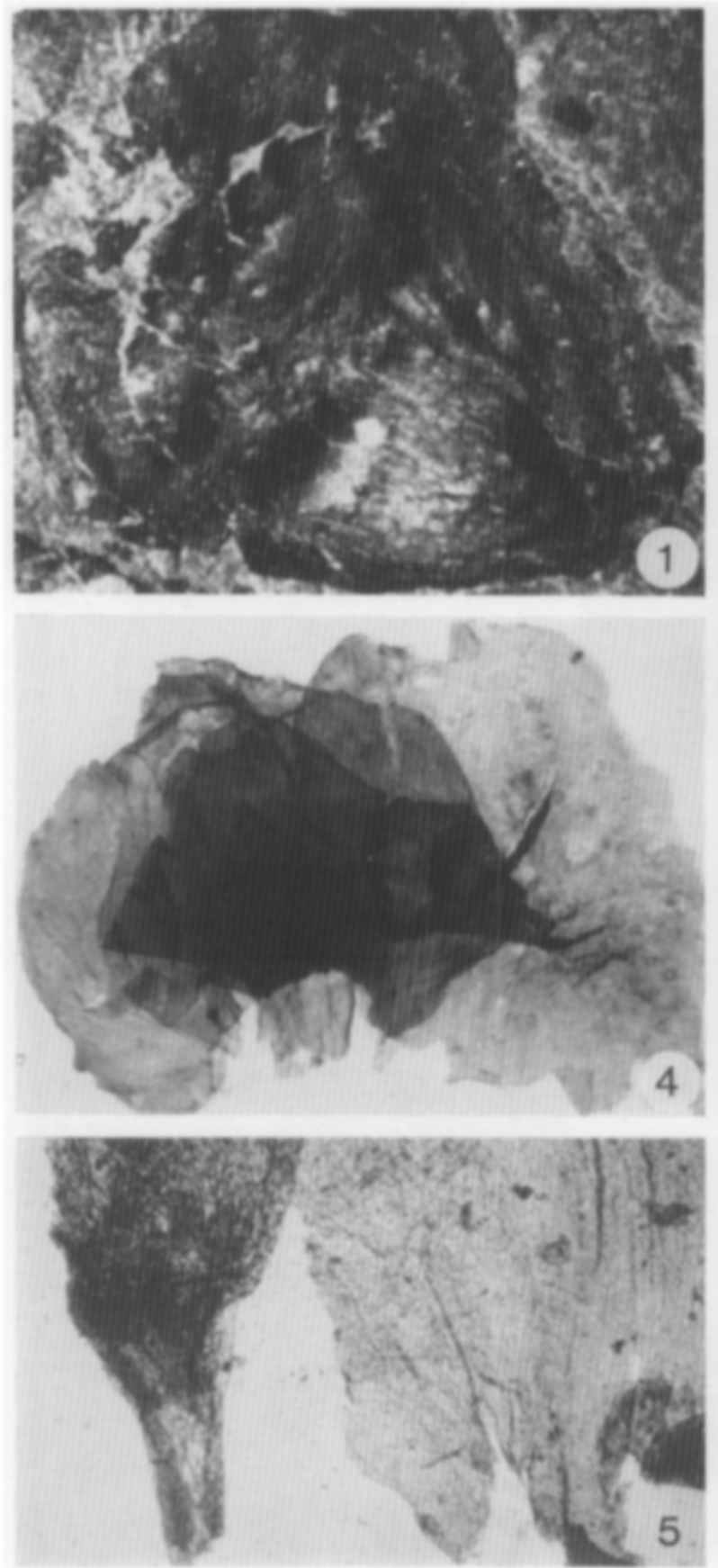

Description on p. 132
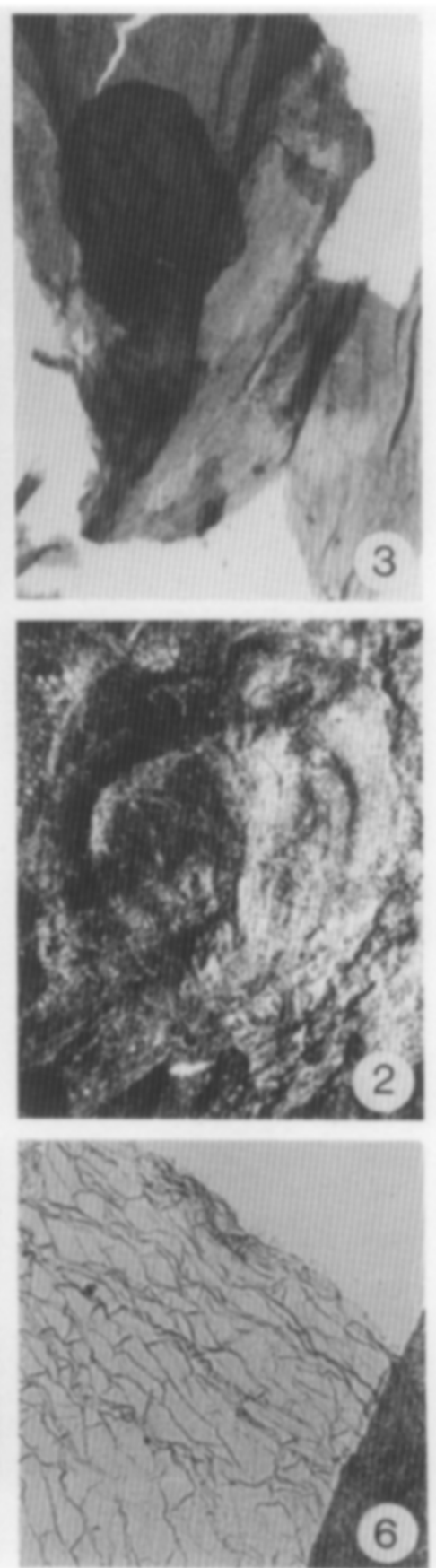
PLATE X
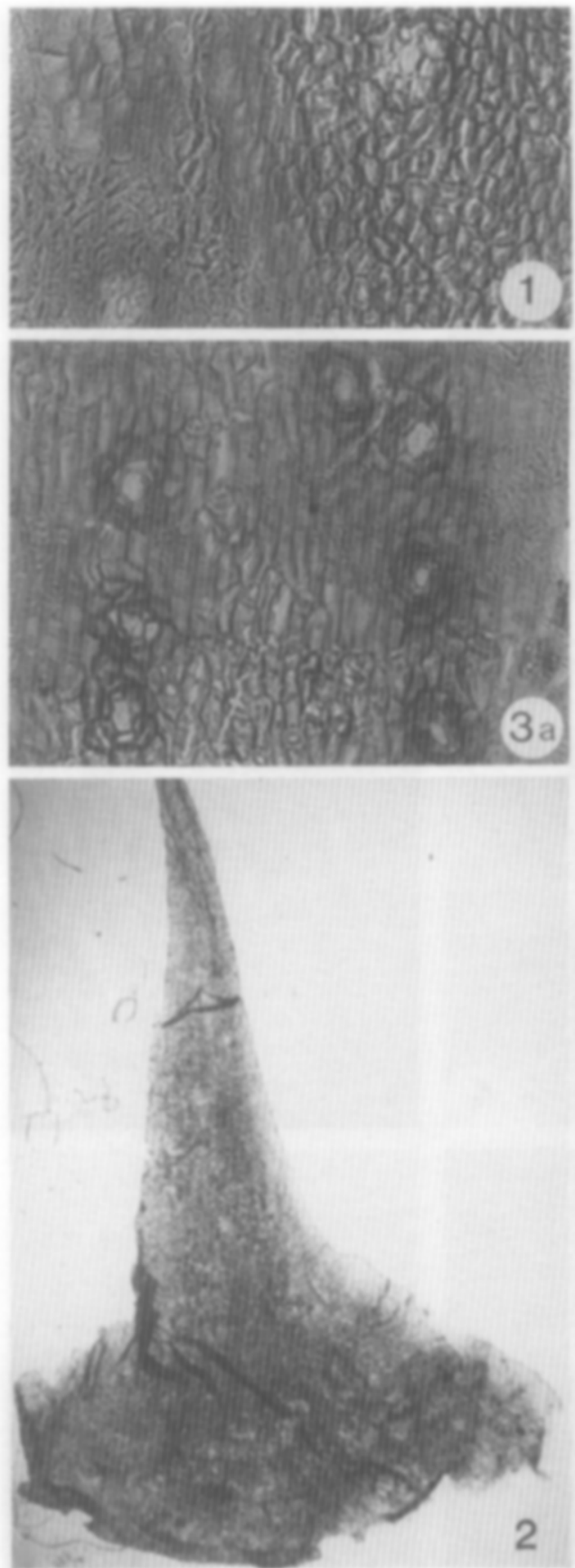

Description on p. 132
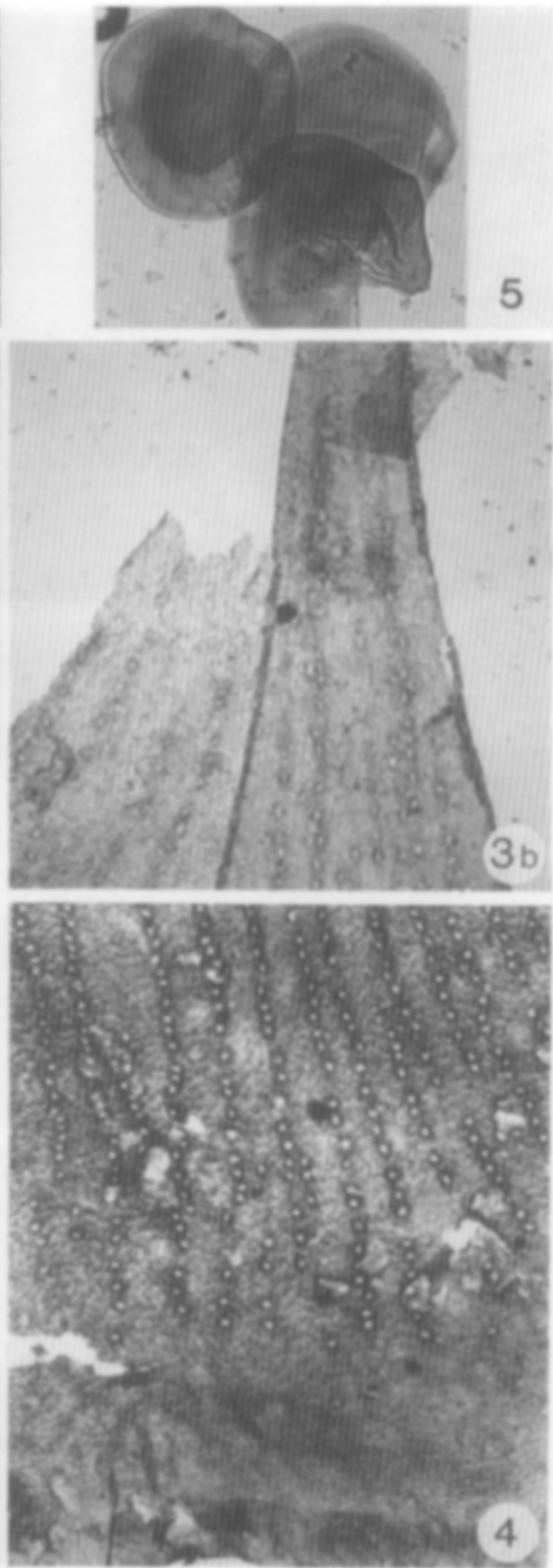


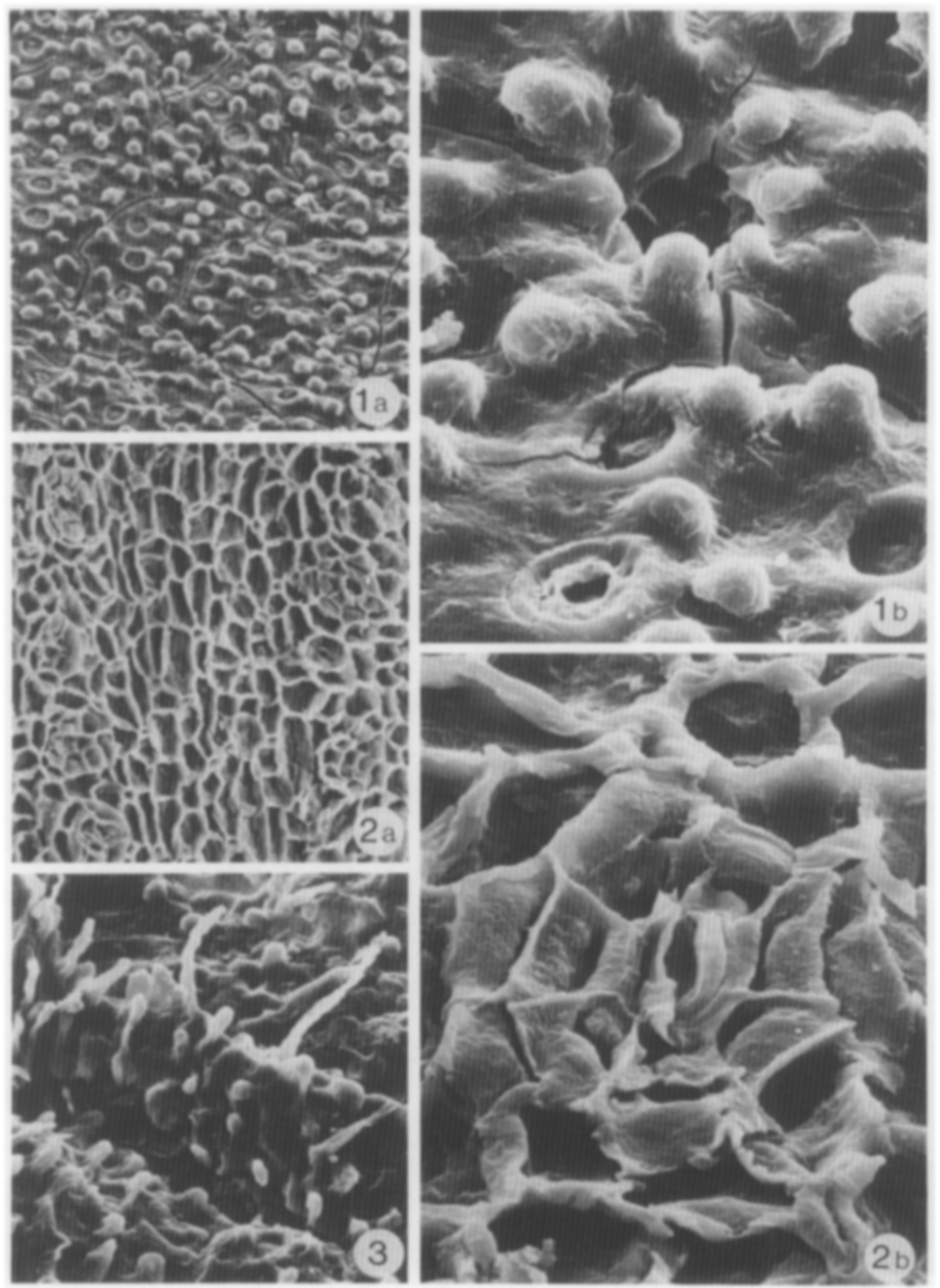



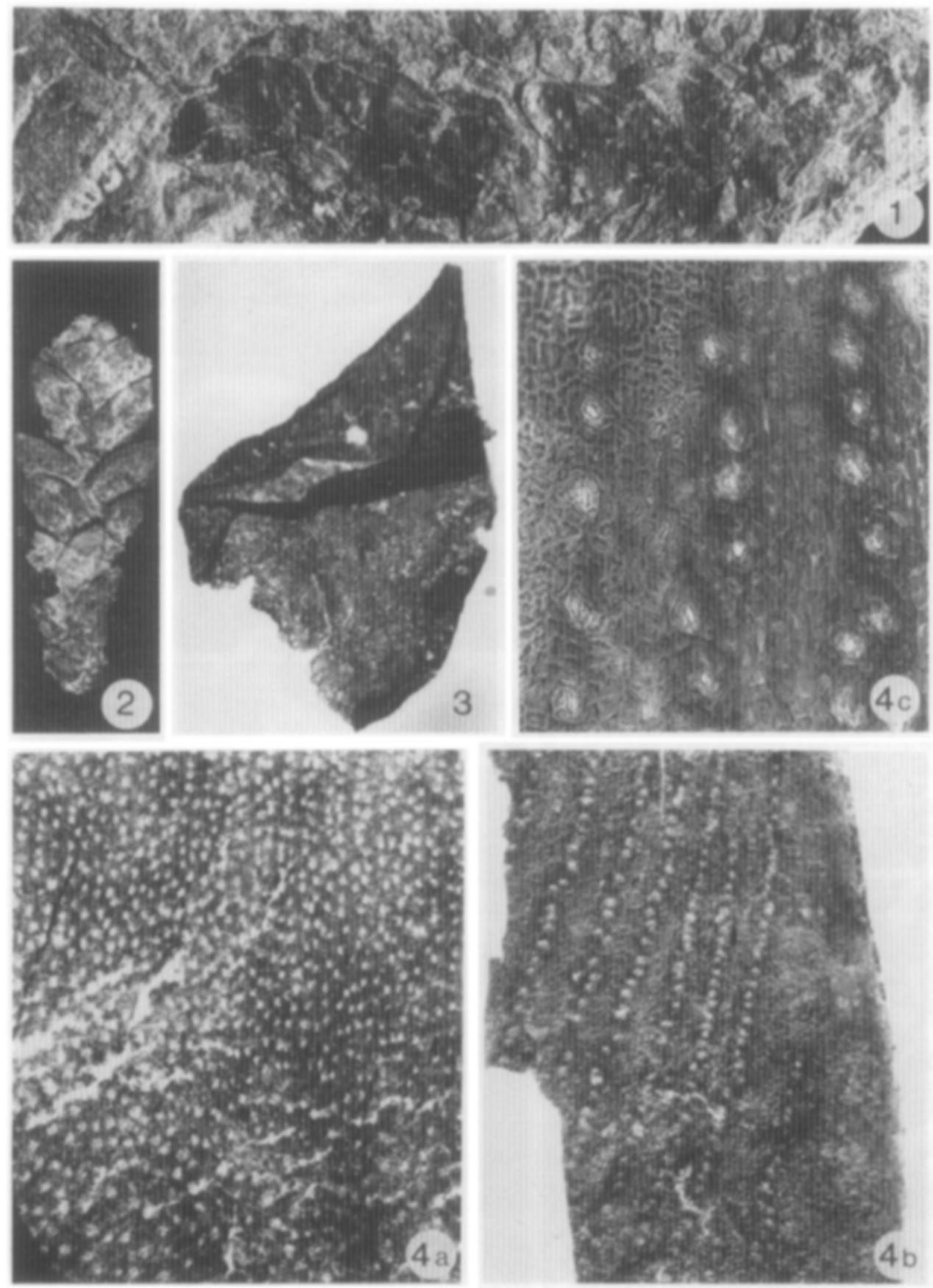
PLATE XIII (p. 138)

Ortiseia visscheri: leaves penultimate order

1. Leaf penultimate order, apical part, $x 11$ (prep. 611; Butterloch R2): a, abaxial surface; $b$, adaxial surface.

2. Leaf penultimate order, basal part (prep. 610; Butterloch R2): a, abaxial surface, showing crowded stomatal complexes, $\times 11 ; \mathrm{b}$, adaxial surface showing stomatal complexes in distinct rows; $c$, detail central part of abaxial surface, $\times 130$.

3. Leaf penultimate order, detail basal part of abaxial surface, $\times 130$ (prep. 609; Butterloch R2).

\section{PLATE XIV (p. 139)}

Ortiseia visscheri: shoot penultimate order, shoot ultimate order, axis ultimate order and leaves ultimate order

1. Shoot penultimate order, fragment holotype, $\times 4.35$ (prep. $615 \mathrm{a}$, originating from specimen 14107; Butterloch R4).

2. Leaf penultimate order, originating from holotype, showing area of attachment, $x$ 11 (prep. 615b, originating from specimen 14107).

3. Leaf penultimate order, originating from holotype, detail apical part of abaxial surface, showing thick cell walls (prep. 615c, originating from specimen 14107; Butterloch R4).

4. Leaf penultimate order, same specimen as figured on Plate XIII, 2, detail showing stomatal complex, $\times 650$ (prep. 610; Butterloch R2).

5. Shoot ultimate order, $\times 4.35$ (prep. 695 ; Butterloch R2).

6. Leaves ultimate order, originating from a single shoot, $\times 4.35$ (prep. 623; Taubenleck RTD).

7. Axis ultimate order, $\times 4.35$ (prep. 622; Taubenleck RTD).

8. Axis ultimate order, fragment showing areas of leaf attachment, $\times 4.35$ (prep. 616; Butterloch R2).

PLATE XV (p. 140)

Ortiseia visscheri: leaves ultimate order and bracts.

1. Leaf ultimate order, basal part, $\times 130$ (prep. 624; Taubenleck RTA): a, abaxial surface; $b$, adaxial surface.

2. Leaf ultimate order, on the left abaxial, on the right adaxial surface, $\times 11$ (prep. 625; Taubenleck RTA).

3. Bract, detached from ovuliferous dwarf-shoot, abaxial surface, $x 11$ (prep. 636; Taubenleck RTA).

4. Bract, $\times 11$ (prep. 633; Taubenleck RTA): a, abaxial surface; b, adaxial surface, note stomata-free lower part.

PLATE XVI (p. 141)

Ortiseia visscheri: bract and ovuliferous dwarf-shoots

1. Bract, detached from dwarf-shoot, detail abaxial surface, $x 130$ (prep. 635; Taubenleck RTA).

2. Dwarf-shoot, basal part, $\times 11$ (prep. 642; Taubenleck RTA), see explanatory sketch Fig.7a.

3. Dwarf-shoot, on the right detached ovule (only basal integumentary extensions), $x$ 4.35 (prep. 644; Taubenleck RTA).

4. Dwarf-shoot, $\times 4.35$ (prep. 640; Butterloch R5-73), see explanatory sketch Fig. $7 \mathrm{~b}$.

5. Dwarf-shoot, basal part, $\times 11$ (prep. 639; Taubenleck RTD), see explanatory sketch Fig. $7 \mathrm{~h}$.

6. Dwarf-shoot, basal part, $\times 11$ (prep. $658 \mathrm{~b}$; Taubenleck RTA): a, see explanatory sketch Fig.7e; b, see explanatory sketch Fig.7f. 
PLATE XIII
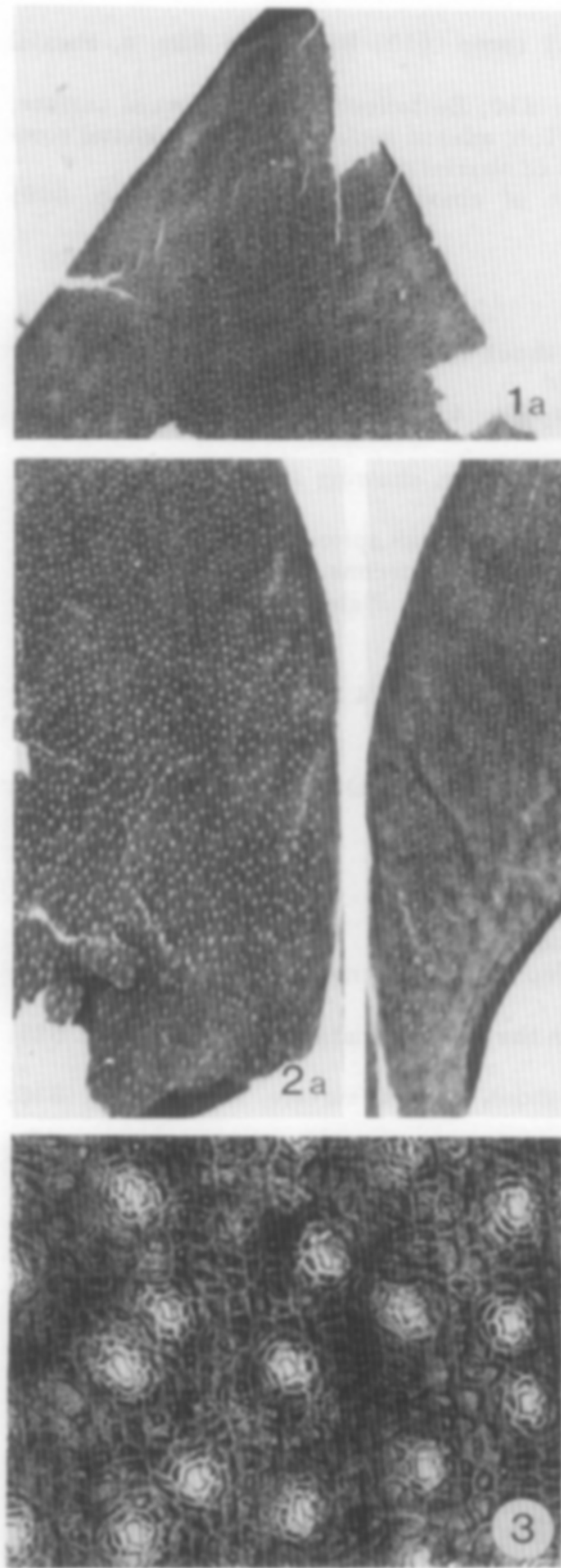

Description on p. 137
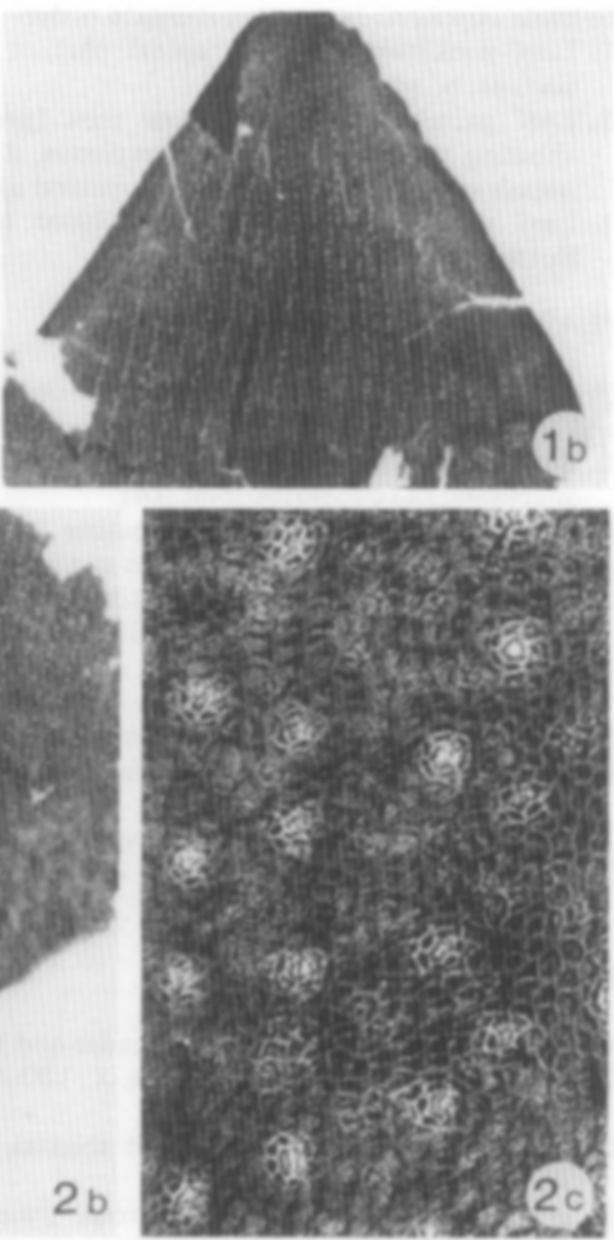

$2 b$

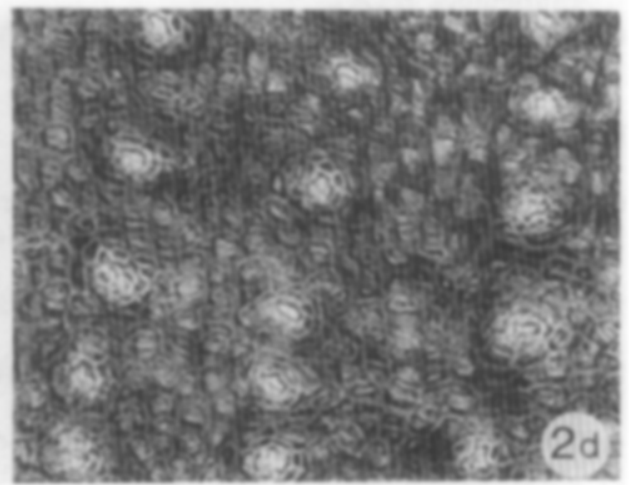


PLATE XIV
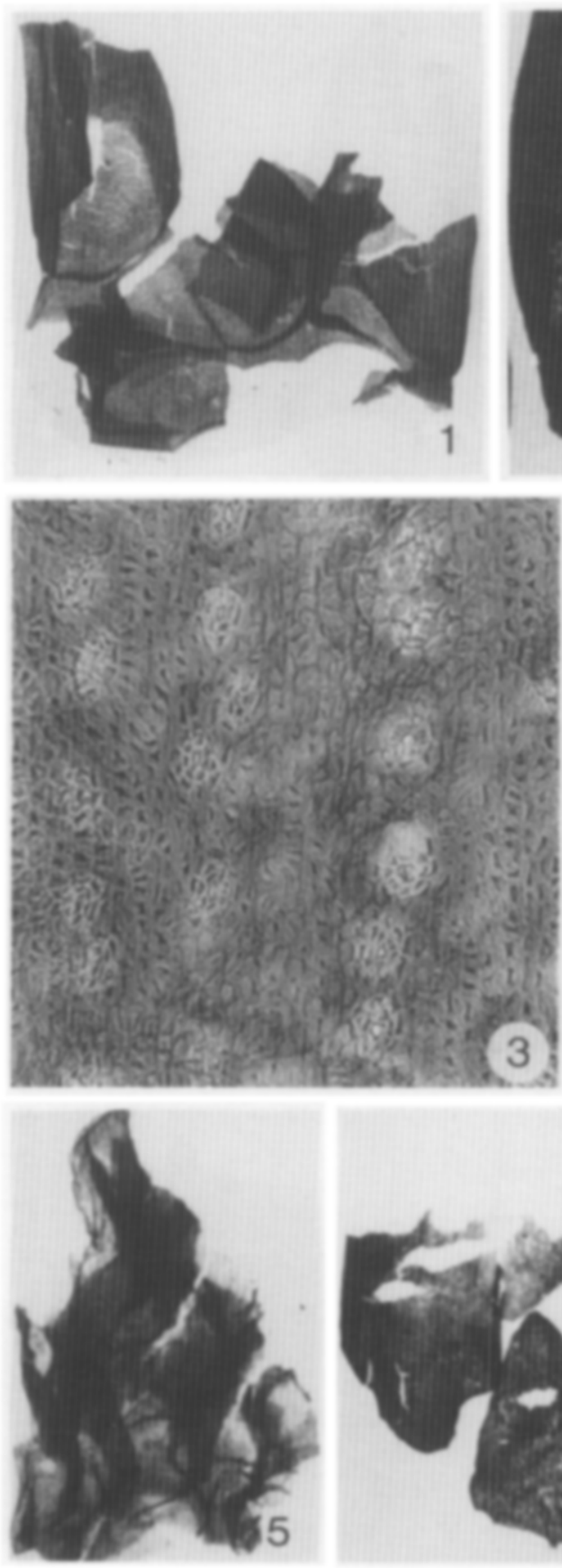
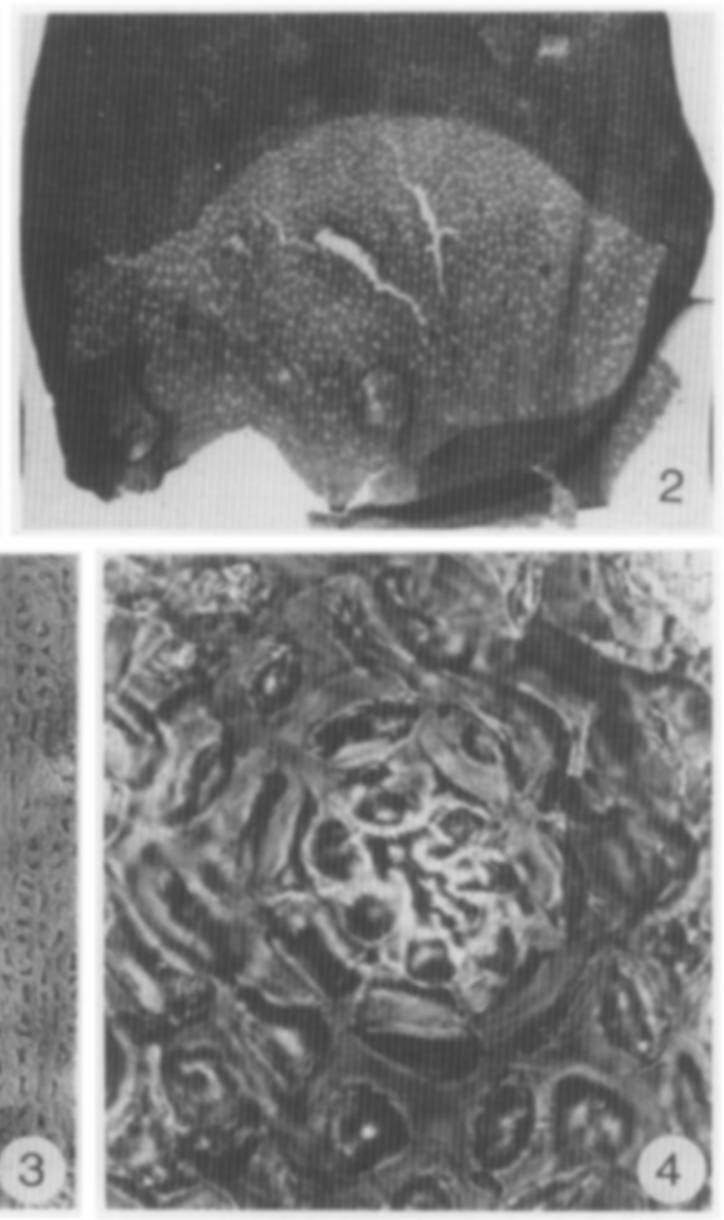

4

Description on p. 137

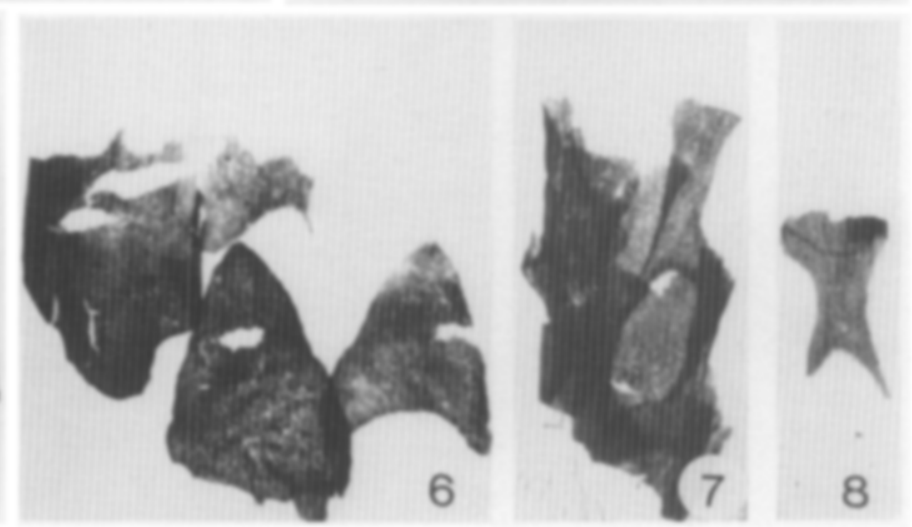


PLATE XV
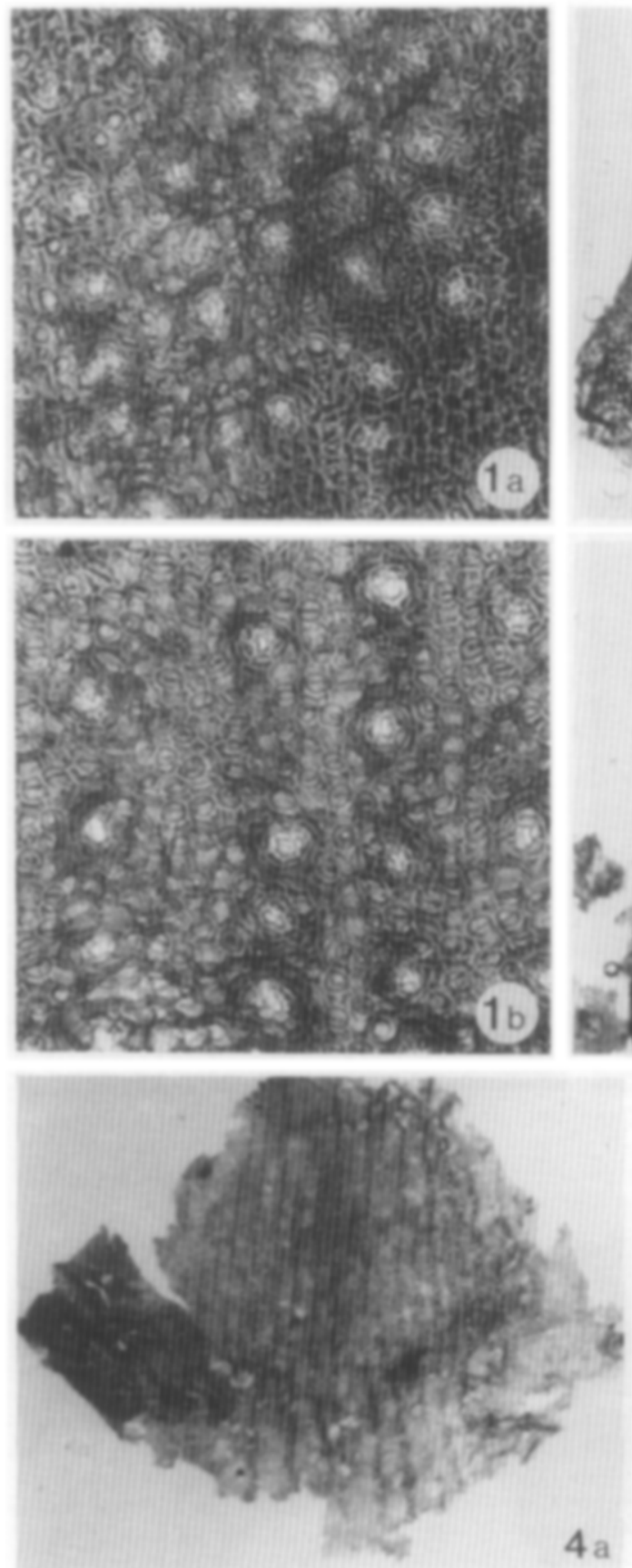

Description on p. 137
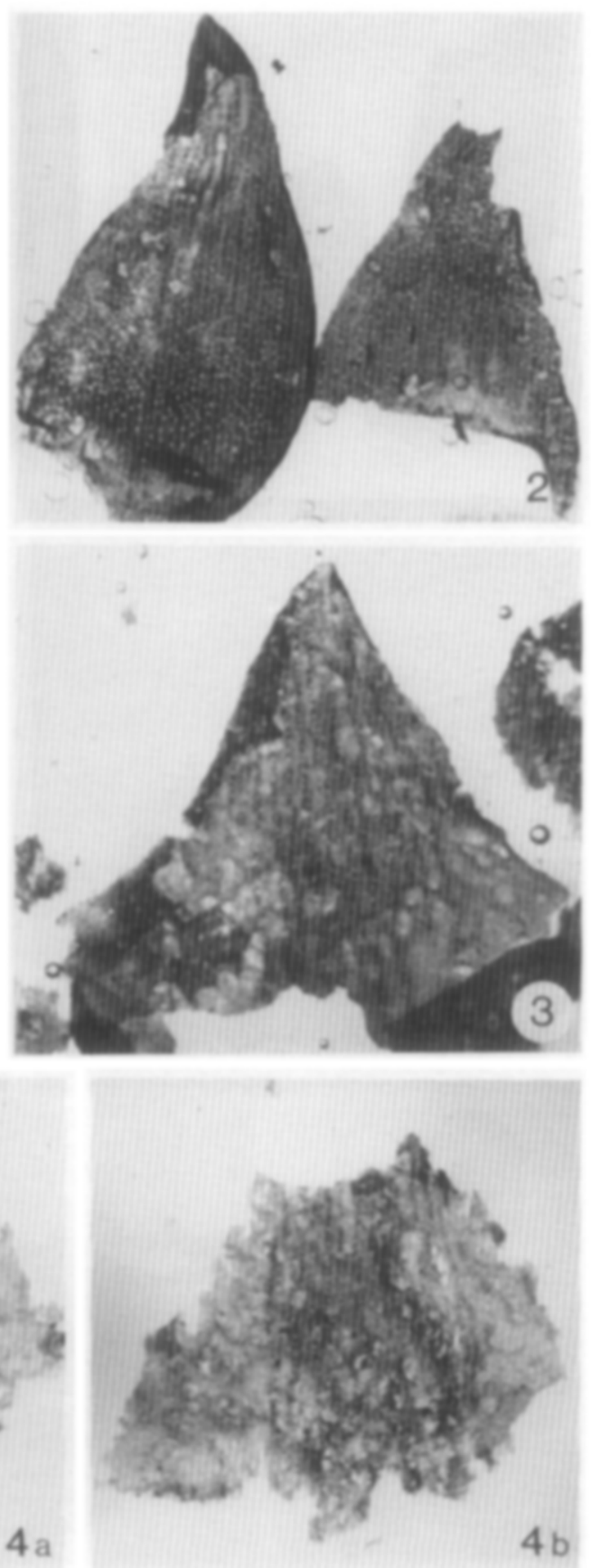
PLATE XVI
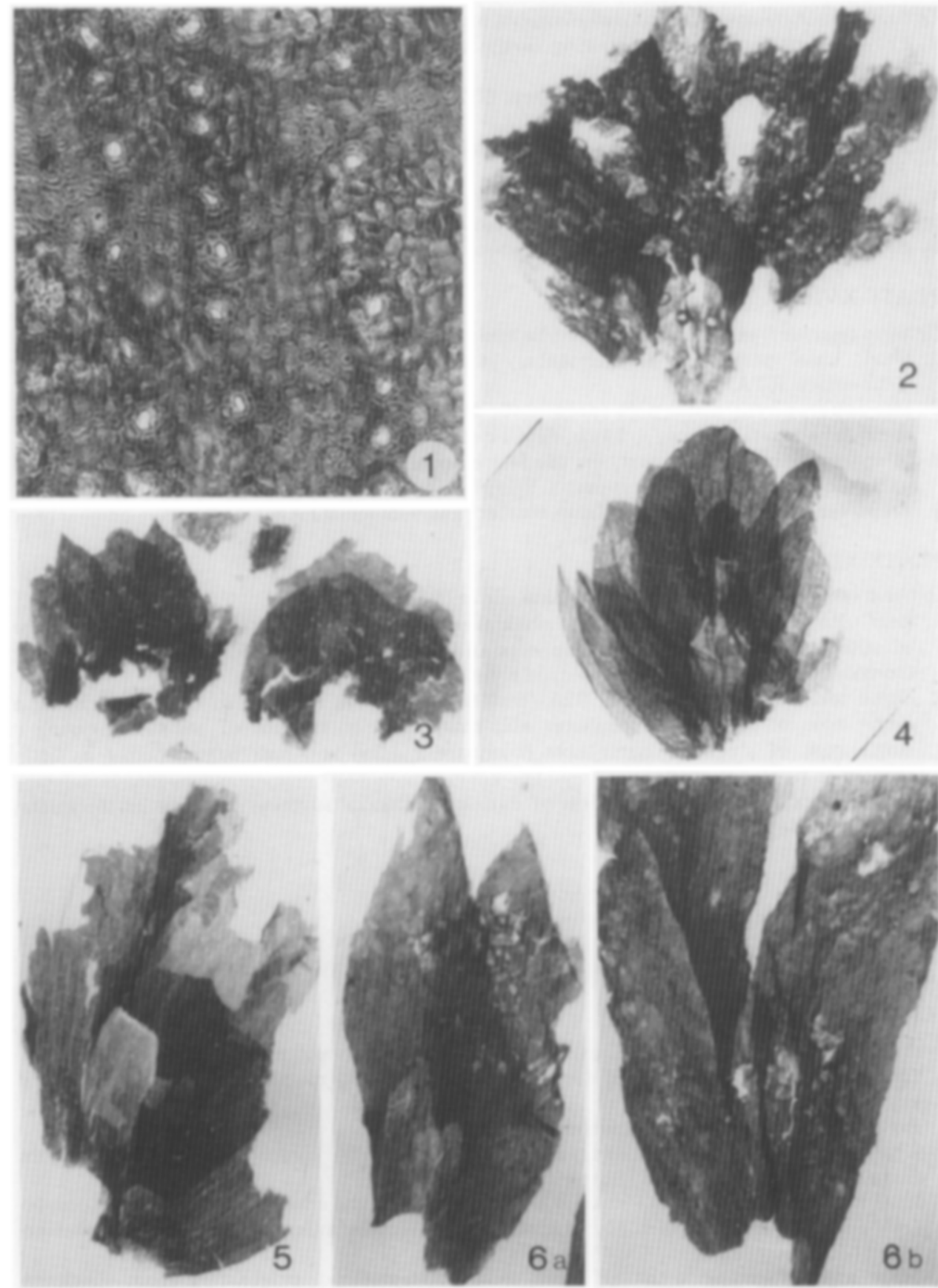
PLATE XVII (p. 143)

Ortiseia visscheri: ovuliferous dwarf-shoots and seed

1. Dwarf-shoot, apical part showing fertile scale, $x 11$ (prep. 655; Taubenleck RTA), see explanatory sketch Fig. $7 \mathrm{c}$.

2. Dwarf-shoot, apical scales, $\times 11$ (prep. 657; Taubenleck RTA), see explanatory sketch Fig.7d.

3. Dwarf-shoot, apical part, ovuliferous scale detached, $x 11$ (prep. 641; Taubenleck RTA), see explanatory sketch Fig.7g.

4. Dwarf-shoot, detail showing hairs, $\times 435$ (prep. 659; Taubenleck RTA).

5. Dwarf-shoot, detail showing epidermal papillae, $\times 130$ (prep. 660; Taubenleck RTA).

6. Seed, basal part with integumentary extensions, $\times 4.35$ (prep. 643 ; Taubenleck RTA).

PLATE XVIII (p. 144)

Ortiseia visscheri: seed microsporophylls and prepollen

1. Seed, basal part with integumentary extensions and hilum, $\times 4.35$ (prep. 696; Taubenleck RTA).

2. Microsporophyll, distal part (prep. 645; Taubenleck RTA): a, on the left abaxial, on the right adaxial surface, $\times 11 ; b$, detail central part abaxial surface, $\times 130$.

3. Microsporophyll, distal part, on the left adaxial, on the right abaxial surface of apical part, showing stomata-free zones, $\times 26$ (prep. 646; Taubenleck RTA).

4. Prepollen, $\times 130$ (originating from cluster; Taubenleck RTA).

PLATE XIX (p. 145)

Ortiseia visscheri: cuticle of leaf ultimate order (SEM)

1. Leaf ultimate order, basal part of abaxial surface, $\times 217$ (Butterloch $R 4$ ): a, exterior of cuticle, showing stomatal complexes and hair bases; $b$, interior of cuticle, showing stomatal complexes, hair bases scarcely visible.

2. Same leaf, adaxial surface, $\times 325$ (Butterloch R4): a, exterior of cuticle, showing a single row of stomatal complexes and hair bases; $b$, interior of cuticle, showing a single row of stomatal complexes (compare Fig.2a) and hair bases, visible as little slits, note thick cell walls.

3. Leaf ultimate order, cross-section of cuticle of abaxial surface, showing its thickness, $\times 870$ (Butterloch R4).

\section{PLATE XX (p. 146)}

Ortiseia jonkeri: lateral shoot systems

1. Lateral shoot system, holotype, $\times 0.87$ (specimen 14108 ; Cortiana).

2. Lateral shoot system, $\times 0.87$ (specimen 14109 ; Cortiana).

\section{PLATE XXI (p. 147)}

Ortiseia jonkeri: main axis with leaves, lateral shoot system and polliniferous cone

1. Lateral shoot system, $\times 1.75$ (specimen 14110; Taubenleck RTD), see explanatory sketch Fig.9.

2. Polliniferous cone, $\times 1.75$ (specimen 14111 ; Ulbe).

3 . Leaf main axis, showing large area of attachment, $\times 11$ (prep. $665 \mathrm{c}$, originating from main axis, specimen 14112; Butterloch R3b).

4. Leaf main axis, on the left abaxial surface, on the right adaxial surface, note stomatafree zones, $\times 11$ (prep. $665 \mathrm{~b}$, originating from main axis, specimen 14112; Butterloch R3b).

5. Main axis, fragment with leaf base, $\times 26$ (prep. $665 \mathrm{~d}$, originating from specimen 14112; Butterloch R3b).

6. Leaf main axis, detail apical part of adaxial surface, showing median stomata-free zone, $\times 130$ (prep. 665 a, originating from main axis, specimen 14112; Butterloch $R 3 \mathrm{~b}$ ).

7. Lateral shoot system, detail axis penultimate shoot, showing folds, $\times 130$ (prep. 666d, originating from specimen 14110; Taubenleck RTD). 


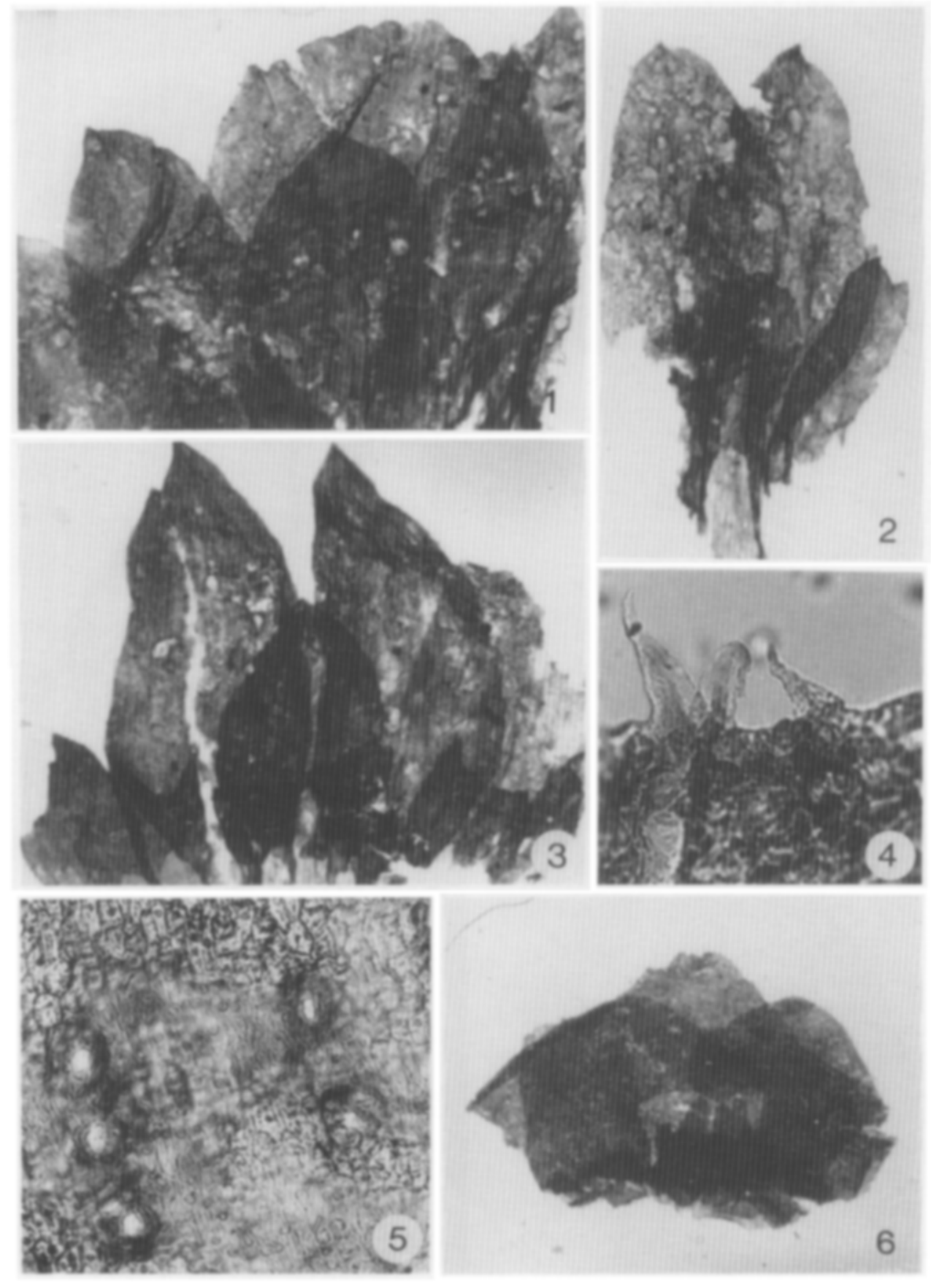


PLATE XVIII
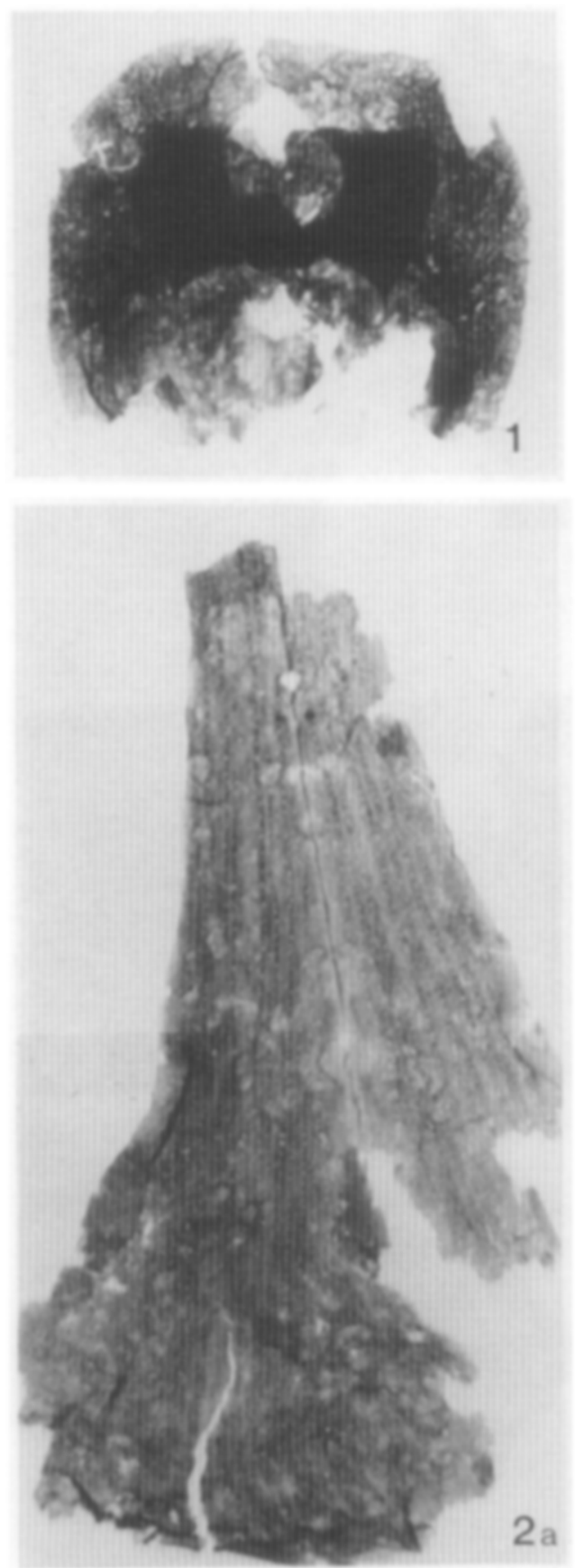

Description on p. 142
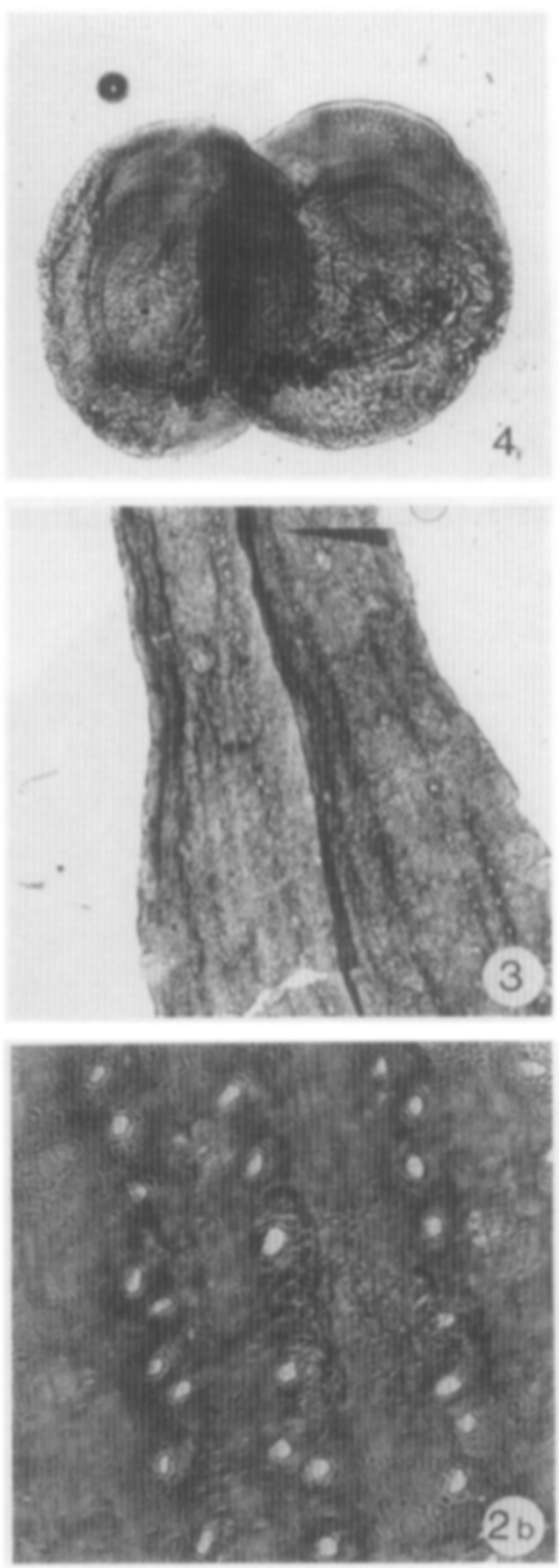

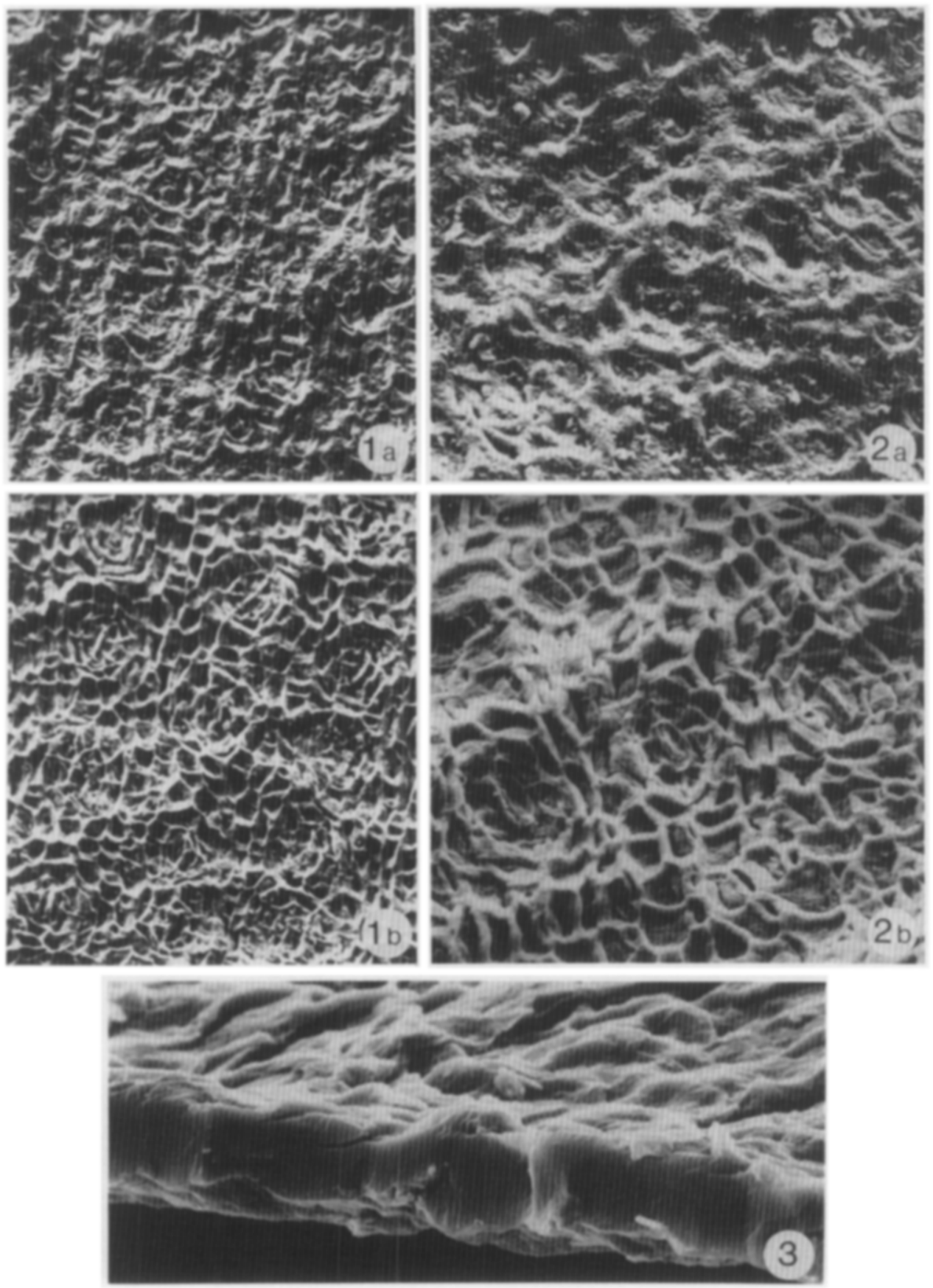


\section{PLATE XX}
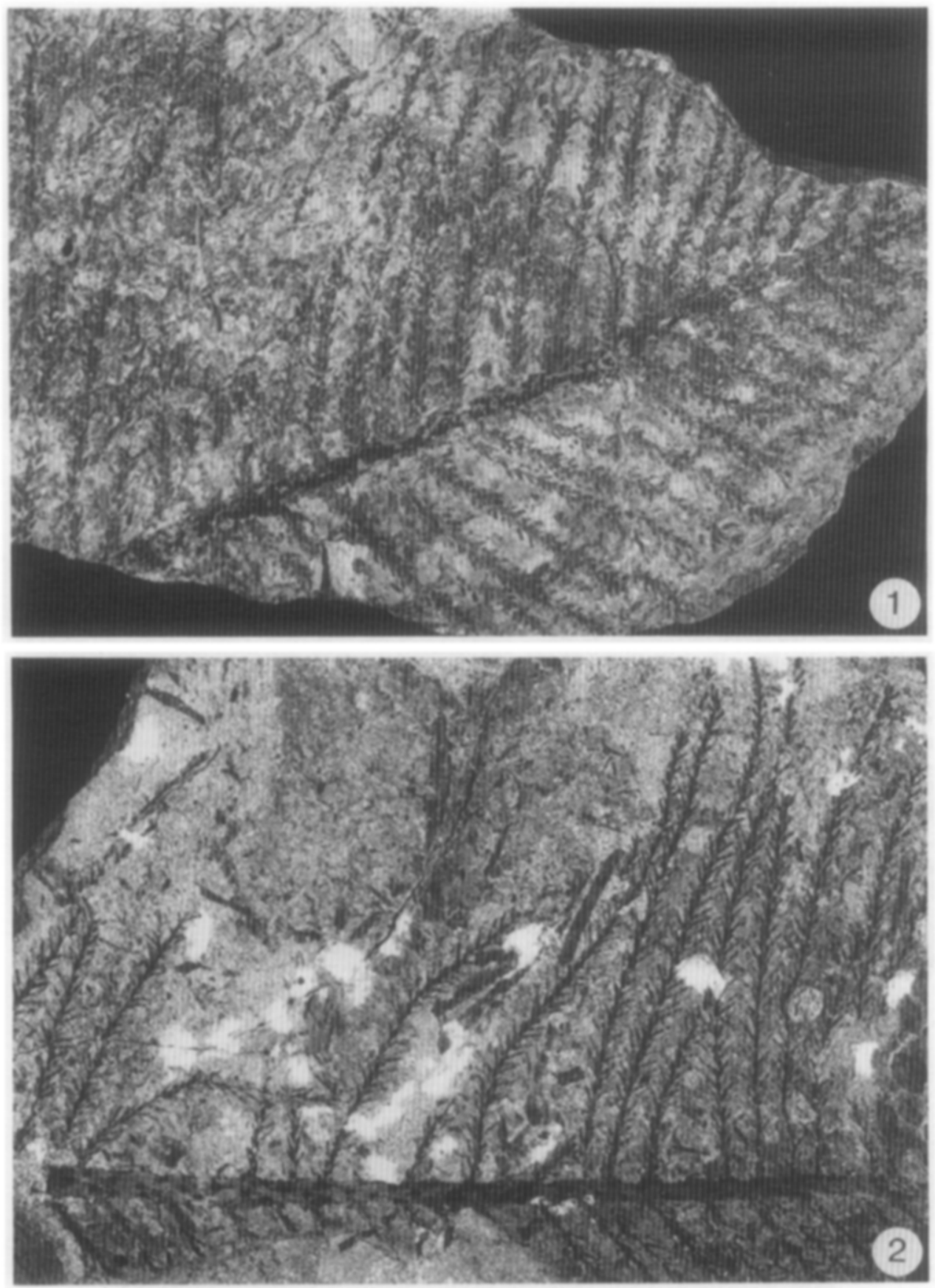


\section{PLATE XXI}
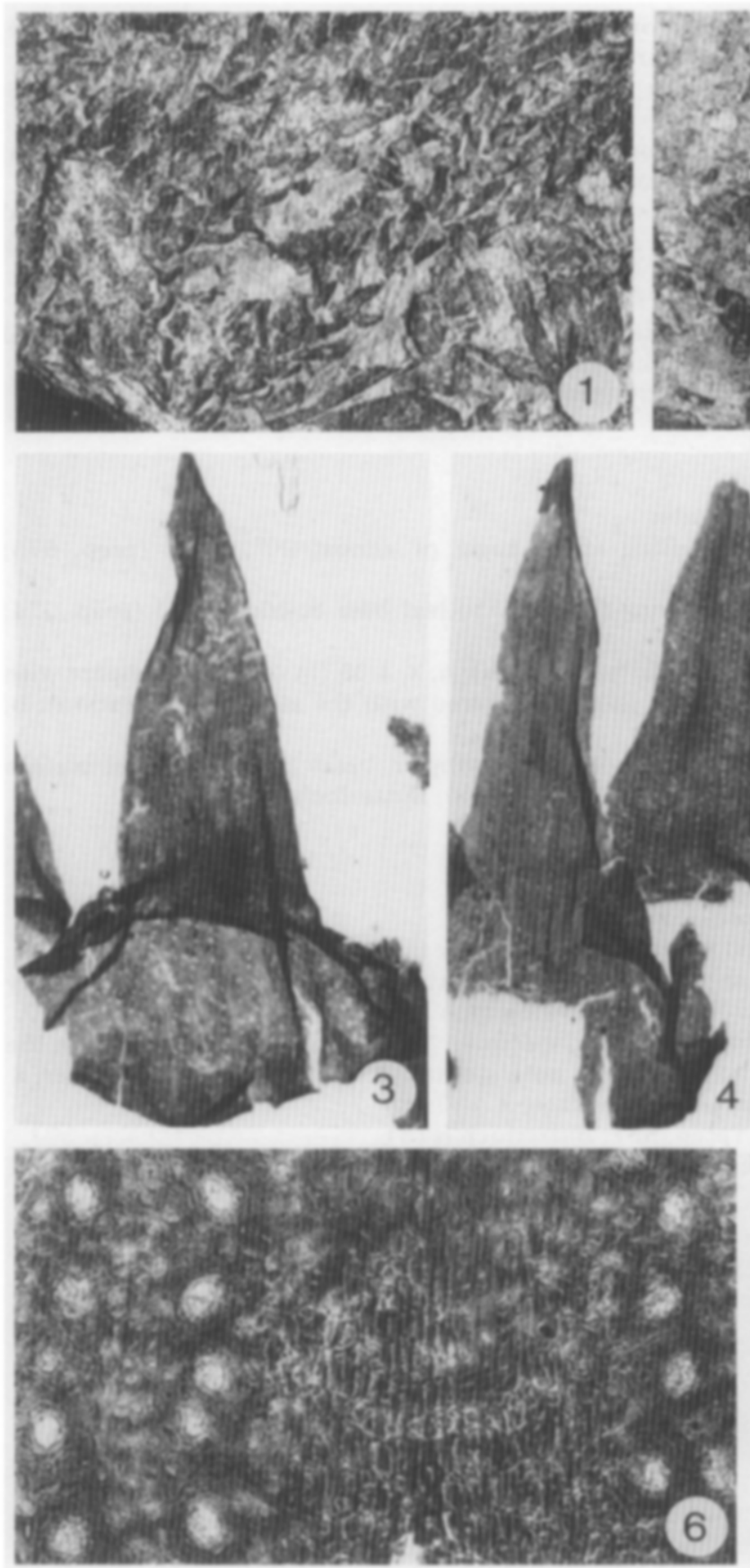

Description on p. 142
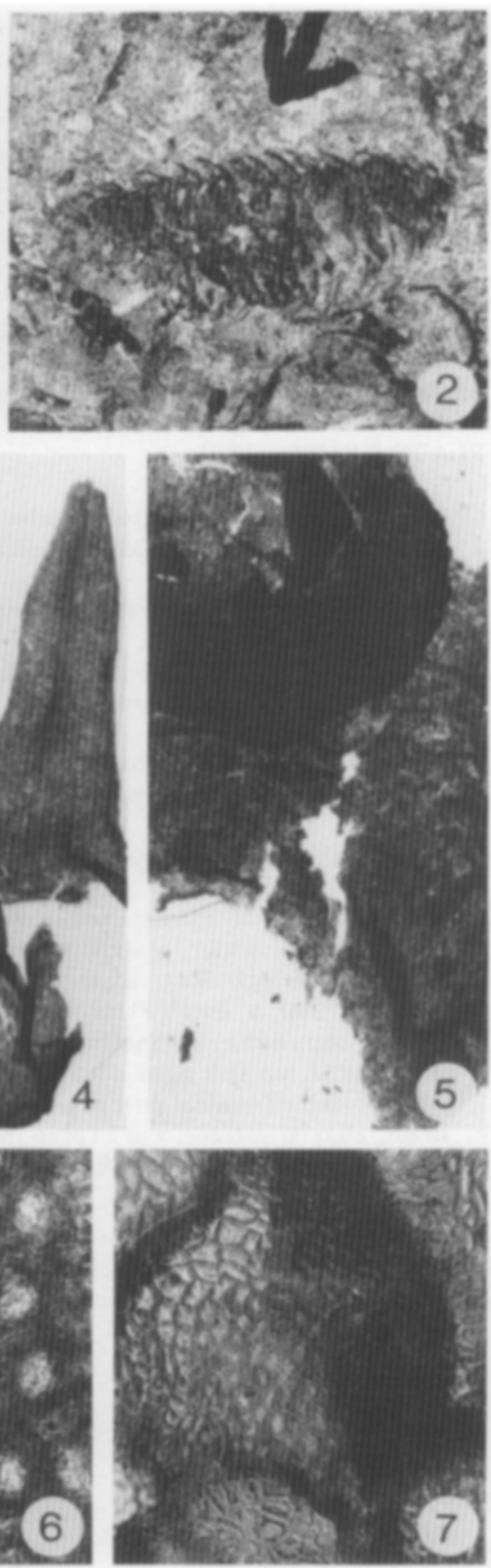
PLATE XXII (p. 149)

Ortiseia jonkeri: shoots penultimate order, leaf penultimate order, shoot ultimate order, axis ultimate order and leaf ultimate order

1. Leaf and axis penultimate order, $\times 11$ (prep. $665 \mathrm{~d}$, originating from main axis, specimen 14112; Butterloch R 3b).

2. Leaf (note bulbous protrusions) and leaf base penultimate order, $\times 11$ (prep. 666a, originating from lateral shoot system, specimen 14110; Taubenleck R $3 b$ ).

3. Leaf penultimate order, epidermal structure abaxial surface, note papillae on epidermal and subsidiary cells (prep. 667; Taubenleck RTD): $a, \times 130 ; b$, detail, showing stomatal complex and hair bases, $\times 650$.

4. Axis ultimate order, $\times 11$ (prep. 678; Taubenleck RTD).

5. Leaf detached from shoot ultimate order, on the left abaxial, on the right adaxial surface, $\times 26$ (prep. 673; Butterloch R4).

6. Shoot ultimate order, fragment, $\times 26$ (prep. 672; Butterloch R4).

\section{PLATE XXIII (p. 150)}

Ortiseia jonkeri: shoots ultimate order

1. Shoot ultimate order, leaves arising at an angle of almost $90^{\circ}, \times 11$ (prep. 675; Taubenleck RTD).

2. Shoot ultimate order, leaves showing tendency to leaf base cushion, $\times 11$ (prep. 674 ; Taubenleck RTD).

3. Shoot ultimate order (prep. 669; Butterloch R3a): a, $\times 4.35$ (in order to compare with shoots of Ortiseia leonardii and $O$. visscheri figured with the same magnification); $b$, $\times 11$.

4. Leaf detached from shoot ultimate order, showing in basal part of abaxial surface monocyclic stomatal complexes, $\times 130$ (prep. 692b; Butterloch R4).

PLATE XXIV (p. 151)

Ortiseia jonkeri: leaf ultimate order, bracts

1. Leaf ultimate order, abaxial surface, same leaf as figured on Plate XXIII, 4 (prep. 692b; Butterloch R4): a, showing dicyclic stomatal complexes, hair bases clearly visible, $X 260$; $b$, detail Plate XXIII, 4, showing monocyclic stomatal complex, $\times 650$.

2. Bract (prep. $685 \mathrm{a}$, originating from cone, specimen 14112 ; Butterloch $R 3 \mathrm{~b}$ ): a, on the left abaxial, on the right adaxial surface, note stomata-free lower part of the latter, $x$ 11 ; b, detail of central part of abaxial surface, $\times 130$.

3. Bract, abaxial surface, $X 11$ (prep. 687; Butterloch R73).

4. Bract, abaxial surface with on either side fragments of neighbouring bracts, $\times 11$ (prep. 686; Butterloch R4). 

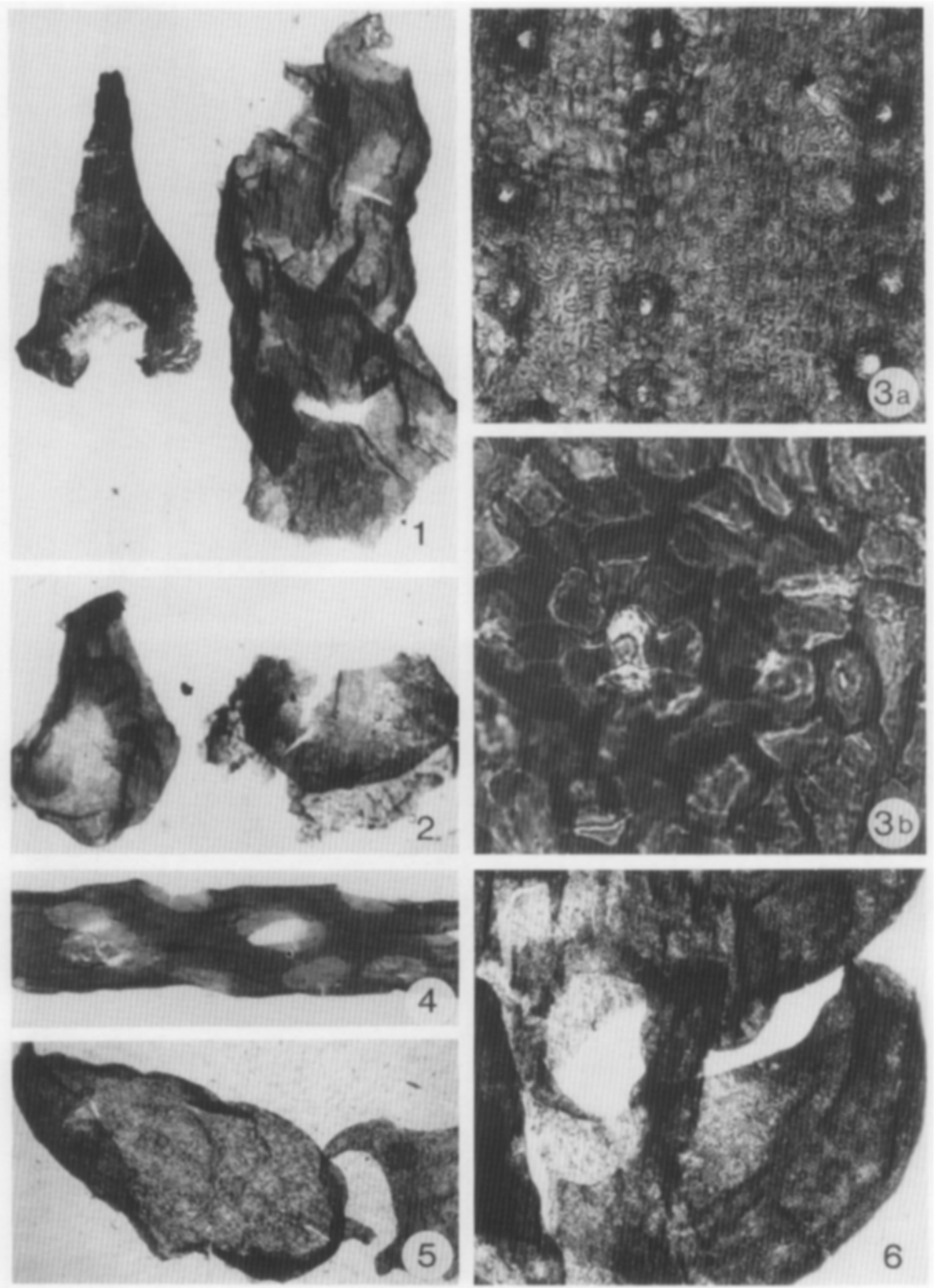

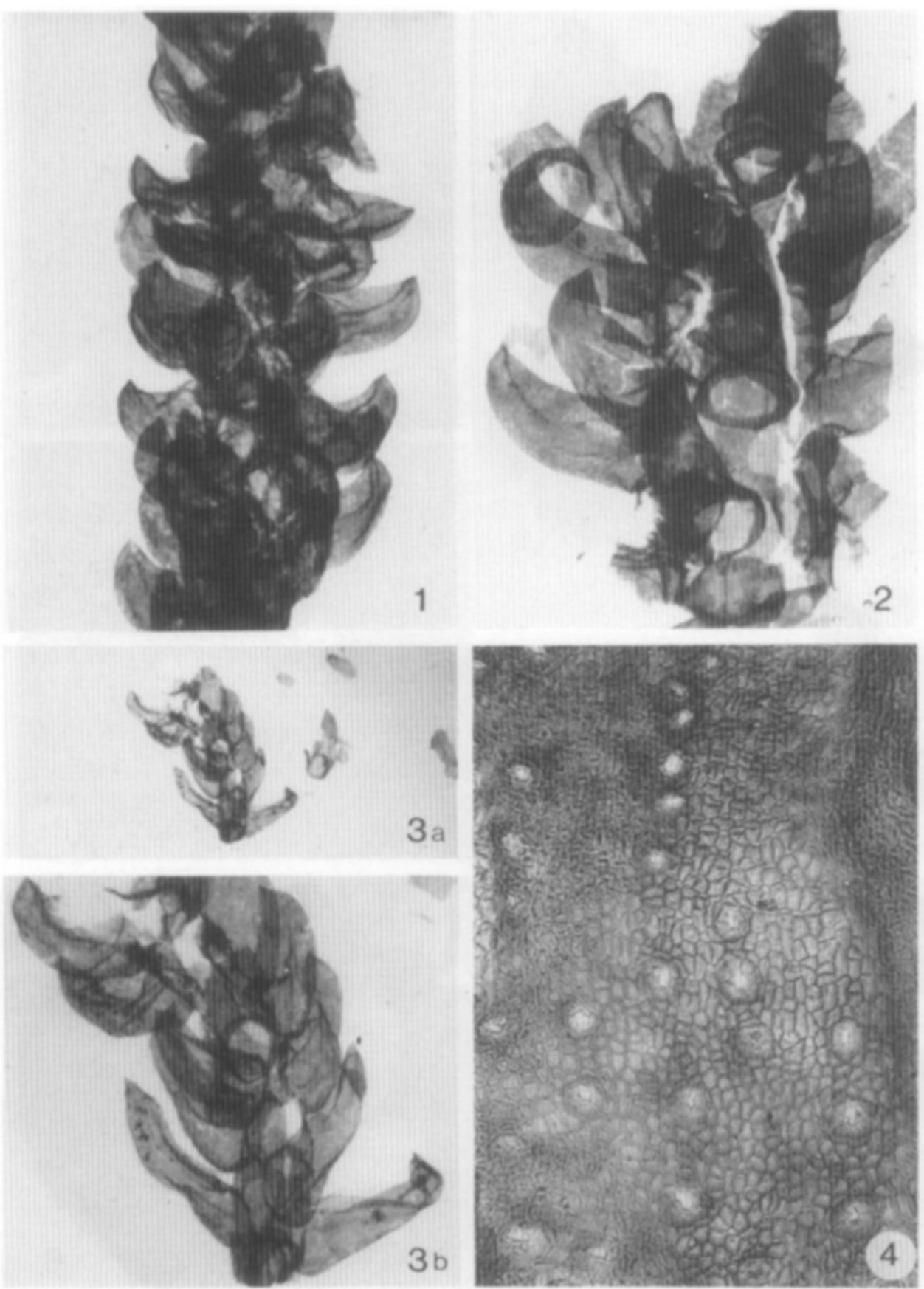
PLATE XXIV
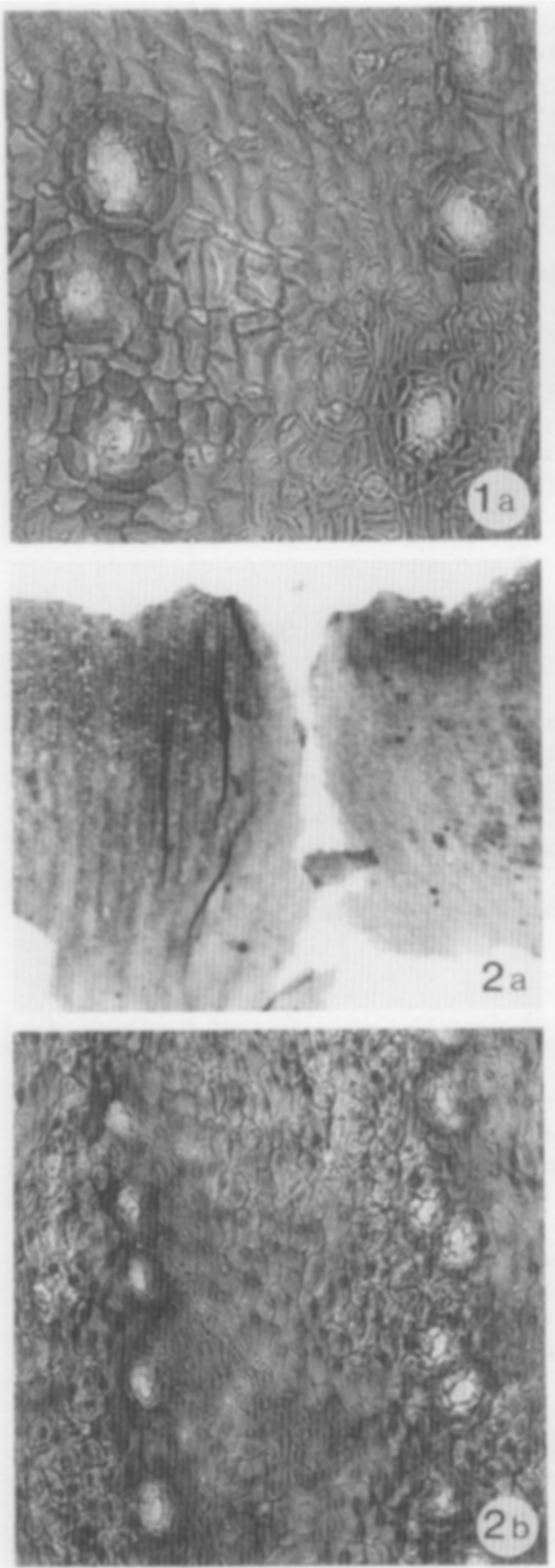

Description on p. 148
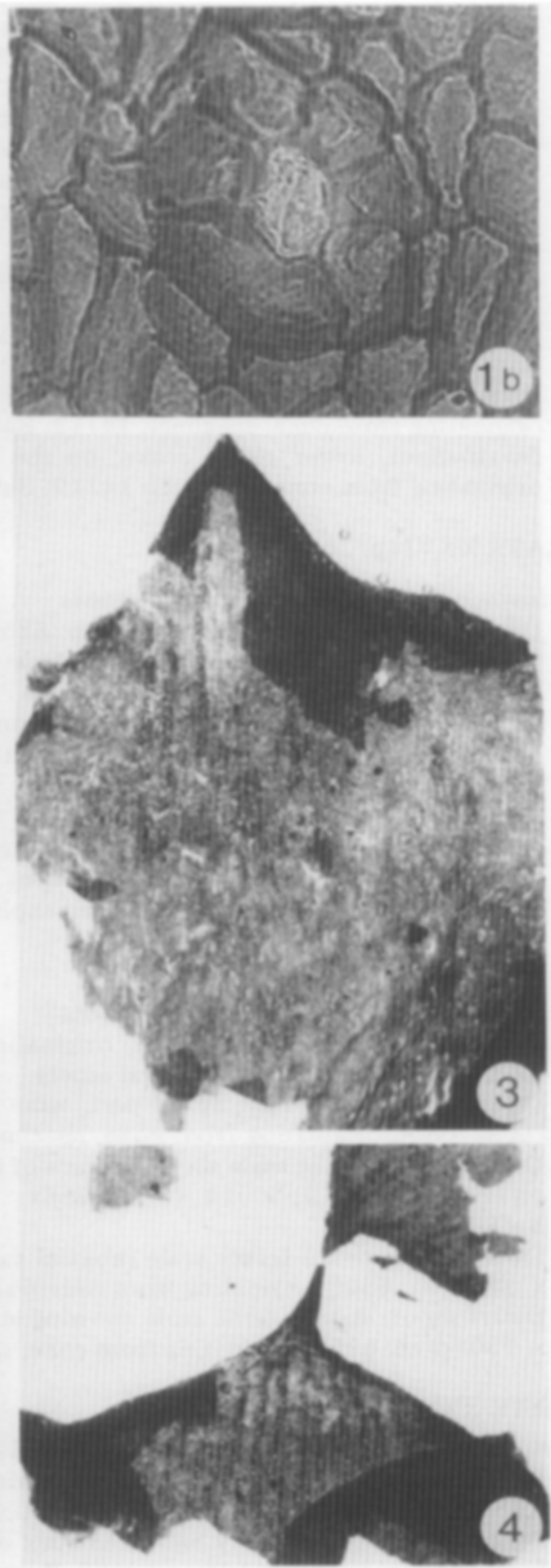
PLATE XXV (p. 153)

Ortiseia jonkeri: bract, ovuliferous dwarf-shoots

1. Bract, detail, non-stomatiferous part of abaxial surface, $\times 130$ (prep. $685 \mathrm{c}$, originating from cone, specimen 14112; Butterloch R3b).

2. Dwarf-shoot, on the left detached ovule, $\times 4.35$ (prep. $680 \mathrm{a}$, originating from conefragment, specimen 14130; Butterloch R3b).

3. Dwarf-shoot with detached ovule (with two lower sterile scales), $\times 4.35$ (prep. $685 \mathrm{~g}$, originating from cone, specimen 14112; Butterloch R3b).

4. Dwarf-shoot with attached ovule, $\times 4.35$ (prep. $685 \mathrm{j}$, originating from cone, specimen 14112), see explanatory sketch Fig.10f.

5. Dwarf-shoot, $\times 4.35$ (prep. $685 \mathrm{~h}$, originating from cone, specimen $14112 ;$ Butterloch R3b).

6. Dwarf-shoot, basal part, $\times 11$ (prep. 682; Taubenleck RTD), see explanatory sketch Fig.10a.

7. Dwarf-shoot, lower sterile scales, on the left 1 , on the right $2, \times 11$ (prep. $685 \mathrm{p}$, originating from cone, specimen 14112; Butterloch R3b).

8. Dwarf-shoot, lower sterile scales, on the left 2 , on the right $4, \times 11$ (prep. $685 \mathrm{n}$, originating from cone, specimen 14112; Butterloch R3b).

PLATE XXVI (p. 154)

Ortiseia jonkeri: ovuliferous dwarf-shoots

1. Dwarf-shoot, basal scales, $\times 11$ (prep. 685o, originating from cone, specimen 14112; Butterloch R3b): a, scale 10 , see explanatory sketch Fig. 10d; b, scales 8 (left) and 4 ; c, scale 11 (on the top of the figure) and 7 ; d, scale 6, see explanatory sketch Fig. 10e.

2. Dwarf-shoot, same specimen as figured on Plate XXV, 7, scale $3, \times 11$ (prep. 685p, originating from cone, specimen 14112; Butterloch R3b).

3. Dwarf-shoot, reconstruction built up of two photographs of the same half of the dwarf-shoot, also figured on Plate XXV, 5; on the left abaxial, on the right adaxial aspect - this reconstruction also demonstrates the difficulty of distinguishing abaxial and adaxial aspects on most photographs, $\times 11$ (prep. $685 \mathrm{k}$, originating from cone, specimen 14112; Butterloch R3b), see explanatory sketch Fig.10b, c.

PLATE XXVII (p. 155)

Ortiseia jonkeri: ovuliferous dwarf-shoots

1. Dwarf-shoot, $x 11$ (prep. 685h, originating from cone, specimen 14112; Butterloch R3b): a, abaxial aspect; $b$, adaxial aspect.

2. Dwarf-shoot with ovule, apical part, same specimen as figured on Plate XXV, $5, \times 11$ (prep. 685j, originating from cone, specimen 14112; Butterloch R3b). (see Fig. 10i).

3. Dwarf-shoot, fertile scale showing place of ovule attachment, same specimen as figured on Plate XXV, $3, \times 11$ (prep. $685 \mathrm{k}$, originating from cone, specimen 14112 ; Butterloch R3b).

4. Dwarf-shoot, detail fertile scale (abaxial surface), showing place of ovule attachment, $\times 26$ (prep. 680f, originating from cone-fragment, specimen 14130 ; Butterloch R3b).

5. Dwarf-shoot, detail sterile scale showing stomatal complexes, papillae and hair bases, $\times 130$ (prep. 685v, originating from cone, specimen 14112; Butterloch R3b).

\section{PLATE XXVIII (p. 156)}

Ortiseia jonkeri: ovuliferous dwarf-shoots and ovules/seeds.

1. Dwarf-shoots, $x 11$ (prep. 685i, originating from cone, specimen 14112; Butterloch R 3b): a, see explanatory sketch Fig.10g; b, see explanatory sketch Fig.10h.

2. Dwarf-shoot, note slightly bilobated apex of fertile scale, $\times 11$ (prep. $680 \mathrm{f}$, originating from cone-fragment, specimen 14130; Butterloch R3b).

3. Dwarf-shoot, sterile scale showing hairs, same specimen as figured on Plate XXVII, 5 , $\times 130$ (prep. 685v, originating from cone, specimen 14112; Butterloch R3b).

4. Ovule, detail of central part of exterior of integument, $\times 130$ (prep. $680 \mathrm{~h}$, originating from cone fragment, specimen 14130; Butterloch R3).

5. Seed, reverse aspect, $\times 4.35$ (specimen 14113; Butterloch R4). 

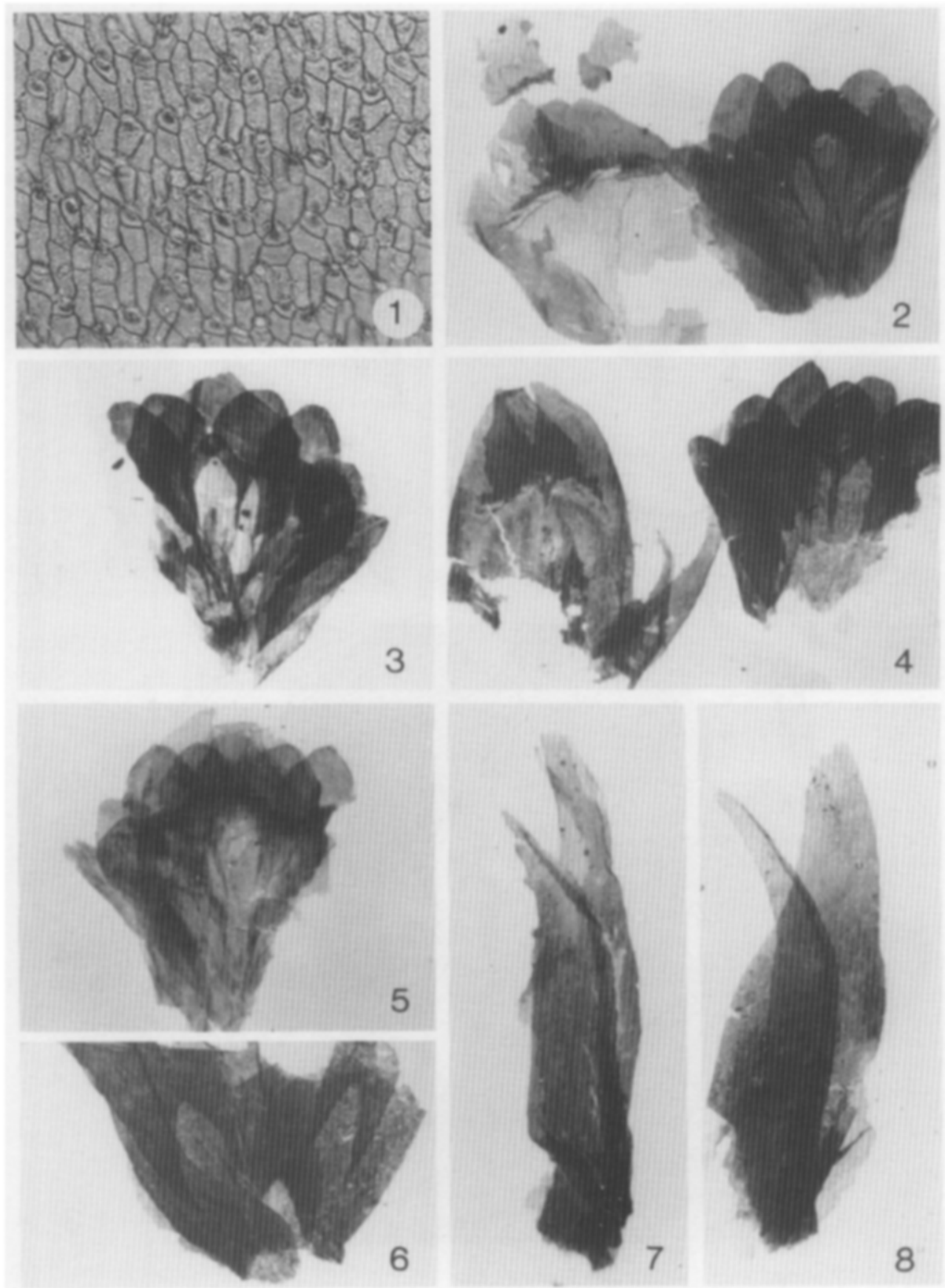
PLATE XXVI

Description on p. 152
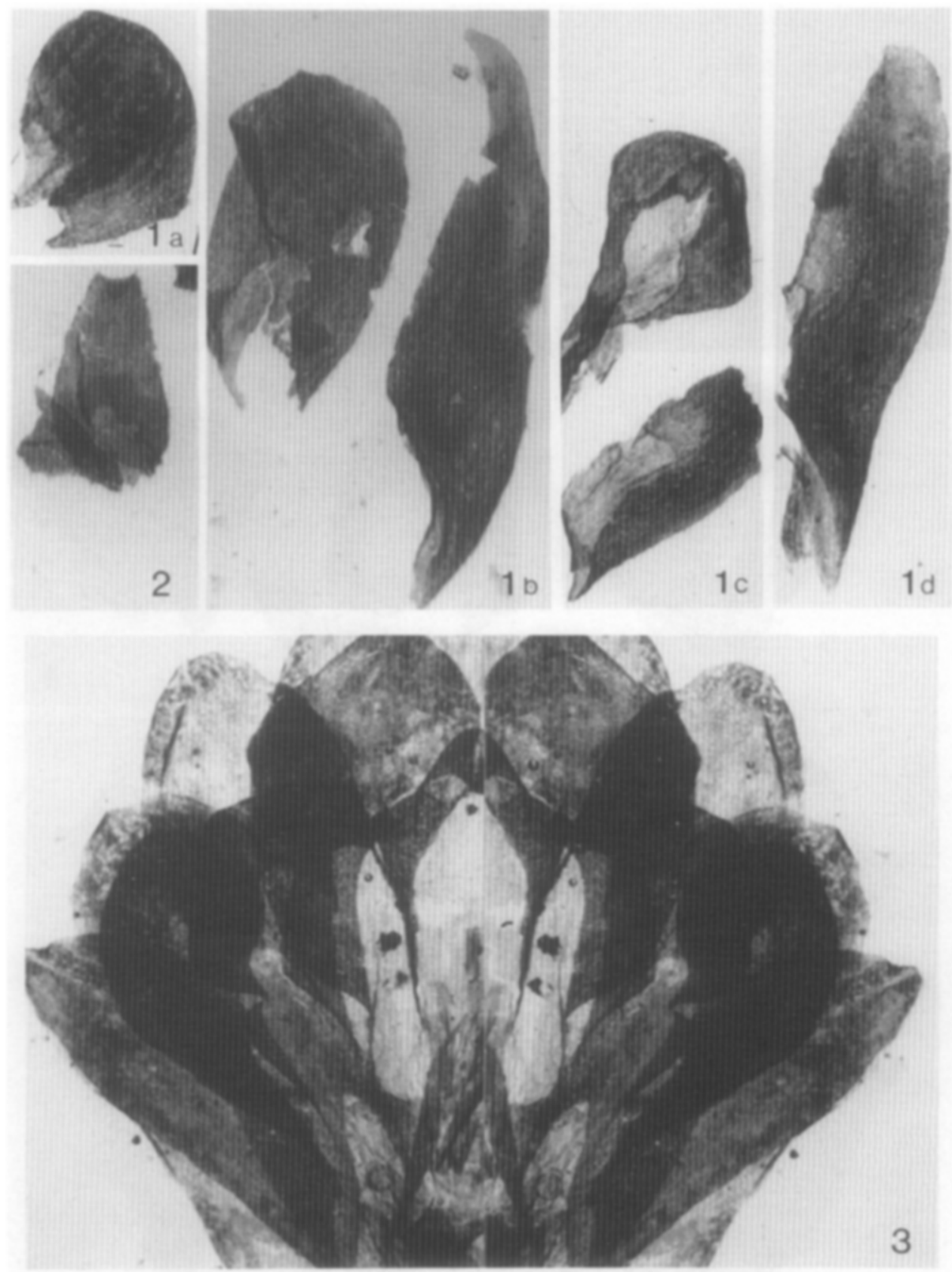
PLATE XXVII
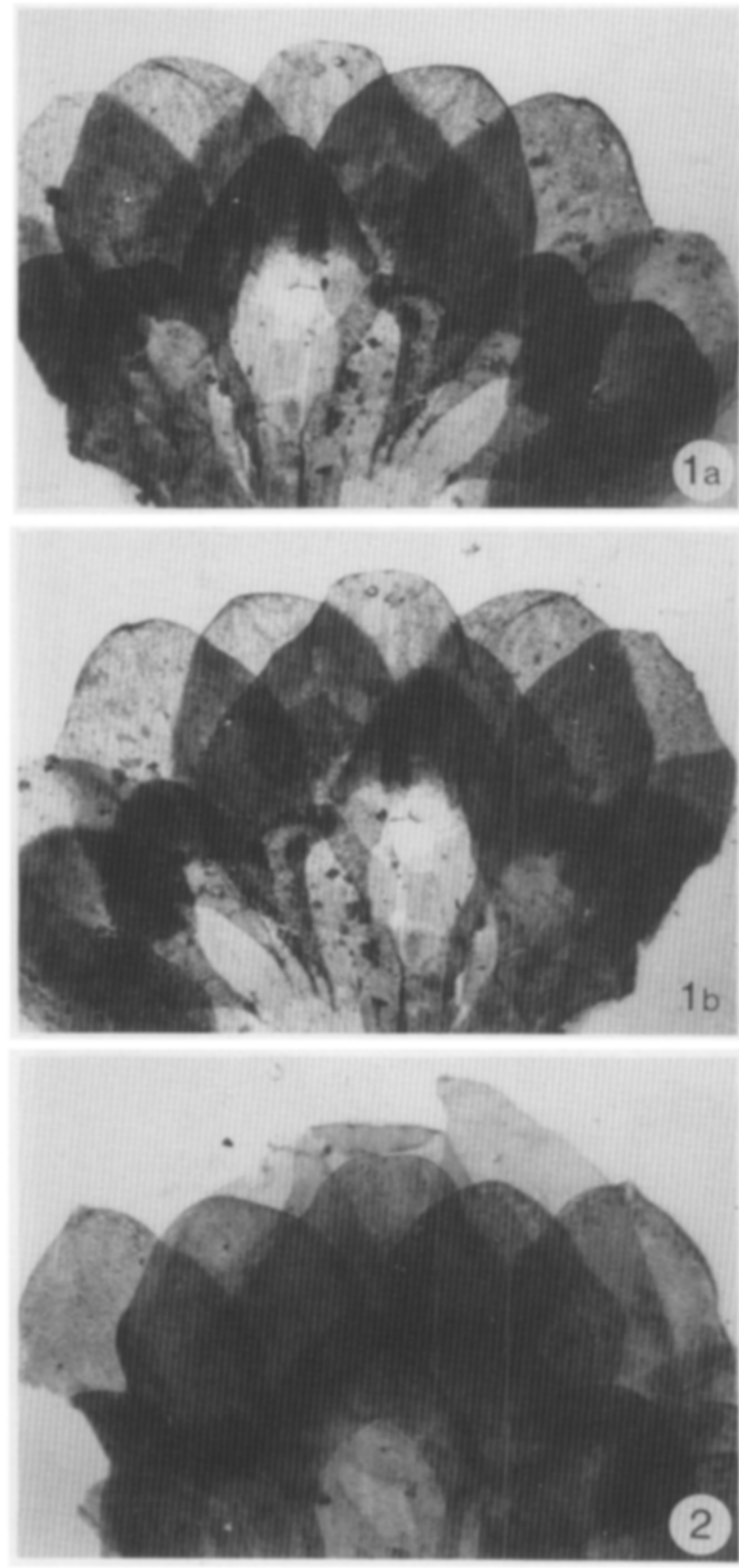

Description on p. 152
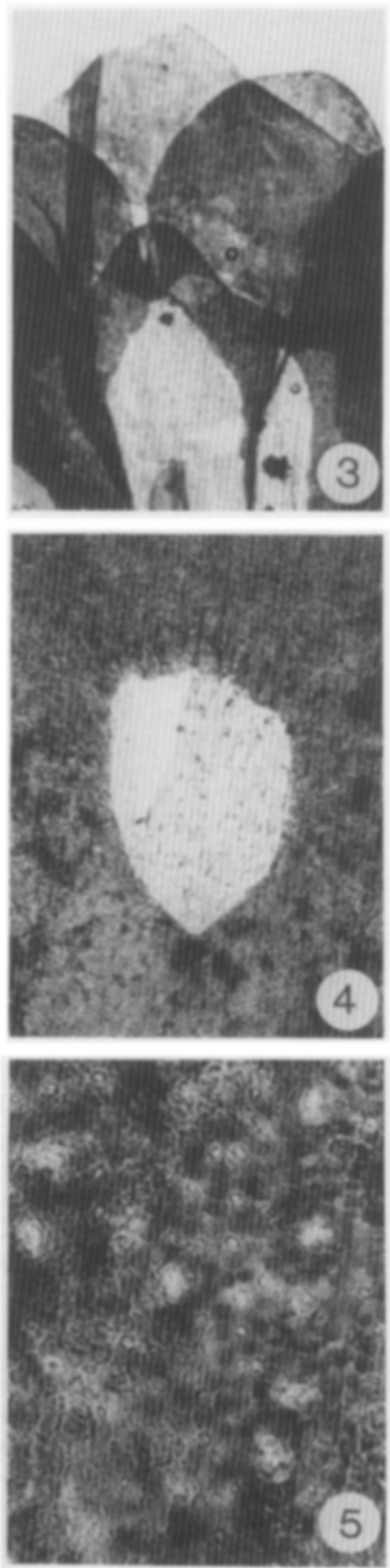
PLATE XXVIII
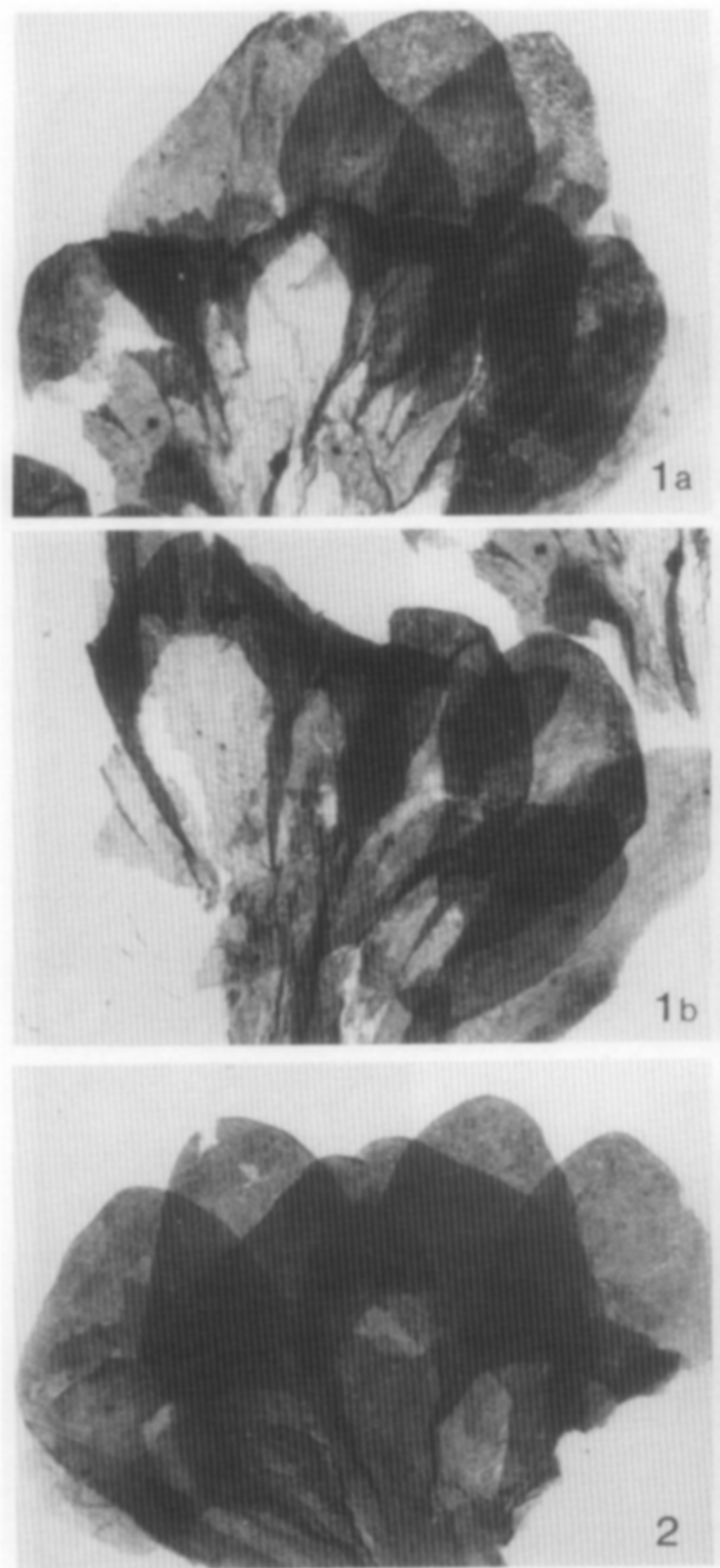

Description on p. 152
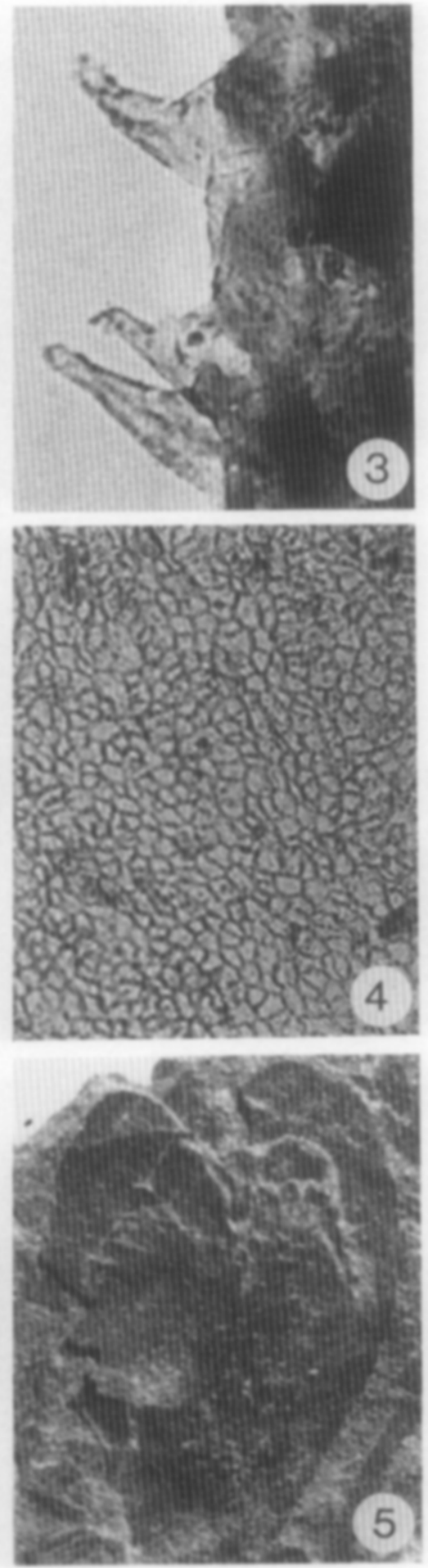
PLATE XXIX (p. 158)

Ortiseia jonkeri: ovules, microsporophylls

1. Ovule, showing megaspore, $X 11$ (prep. 685s, originating from cone, specimen 14112; Butterloch R3b).

2. Ovule, basal part showing (partly) integumentary extensions, $\times 11$ (prep. $685 \mathrm{f}$, originating from cone, specimen 14112; Butterloch R3b).

3. Ovule, apical part, showing micropylar canal and pollen-chamber containing two grains of Nuskoisporites type (prep. 685t, originating from cone, specimen 14112; Butterloch R3b): a, X 11; b, $\times 26$.

4. Microsporophylls, distal parts, $\times 11$ (prep. 697; Butterloch R4).

5. Microsporophyll, adaxial surface of distal part, showing stomata in bands on either side of a median stomata-free zone, $\times 130$ (prep. $690 \mathrm{~b}$, originating from cone, specimen 14115; Butterloch R4).

PLATE XXX(p. 159)

Ortiseia jonkeri: polliniferous cone, microsporophylls and prepollen

1. Polliniferous cone, $x 11$ (prep. 688; Butterloch R4): a, apical part; b, basal part.

2. Microsporophyll, distal part showing basal stomata-free area, $\times 11$ (prep. 690a, originating from cone, specimen 14115; Butterloch R4).

3. Microsporophyll, distal part, same specimen as figured on Plate XXIX, 5, X 26 (prep. $690 \mathrm{~b}$, originating from cone, specimen 14115; Butterloch R4): a, abaxial surface, note stomata-free zones; $b$, adaxial surface.

4. Prepollen, $\times 130$ (originating from cone, specimen 14115; Butterloch R4).

\section{PLATE XXXI(p. 160)}

Ortiseia jonkeri: cuticle of leaf ultimate order, ovuliferous dwarf-shoot and microsporophyll (SEM)

1. Leaf ultimate order, abaxial surface, exterior of cuticle, showing no characteristic features, stomatal complexes hardly recognizable, $X 325$ (Butterloch $R 4$ ).

2. Same leaf, abaxial surface, interior of cuticle: a, showing bordering stomatal complexes, $\times 375 ; b, \times 130$.

3. Microsporophyll, distal part, abaxial surface, interior of cuticle (compare Fig.2a), $\times 325$ (originating from cone, specimen 14115; Butterloch R4).

4. Dwarf-shoot, sterile scale showing hairs, $\times 260$ (originating from cone, specimen 14112; Butterloch R3b).

\section{PLATE XXXII (p. 161)}

\section{Prepollen of Ortiseia (Nuskoisporites)}

1. Proximal aspect, trilete mark open, $\times 300$ (Butterloch R4).

2. Distal aspect, note the circular elevation, caused by the compression of the nexine, $x$ 375 (Butterloch, R3b).

3. Cross-section, note the proximal trilete mark, the equatorial folds of the nexine and the absence of a distal sexinal thinning, $\times 1300$ (Butterloch R4).

4. Proximal aspect, preformed trilete mark in proximal sexine still closed (Butterloch, R4): a, $\times 375$; b, detail, $\times 2000$. 
PLATE XXIX
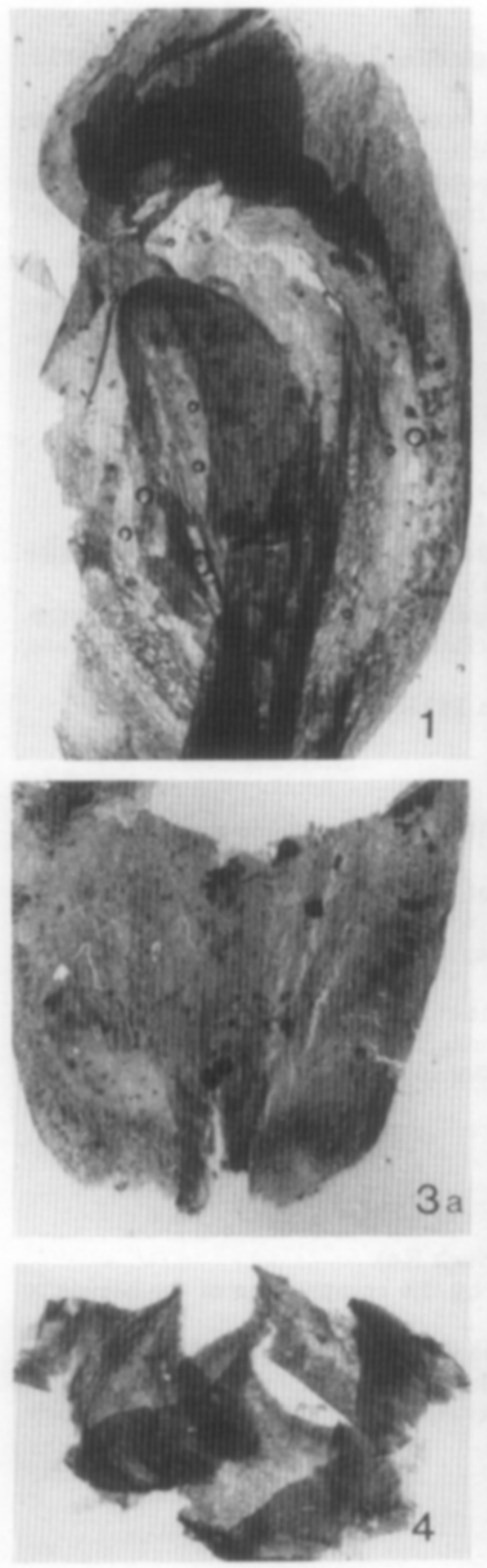

Description on p. 157
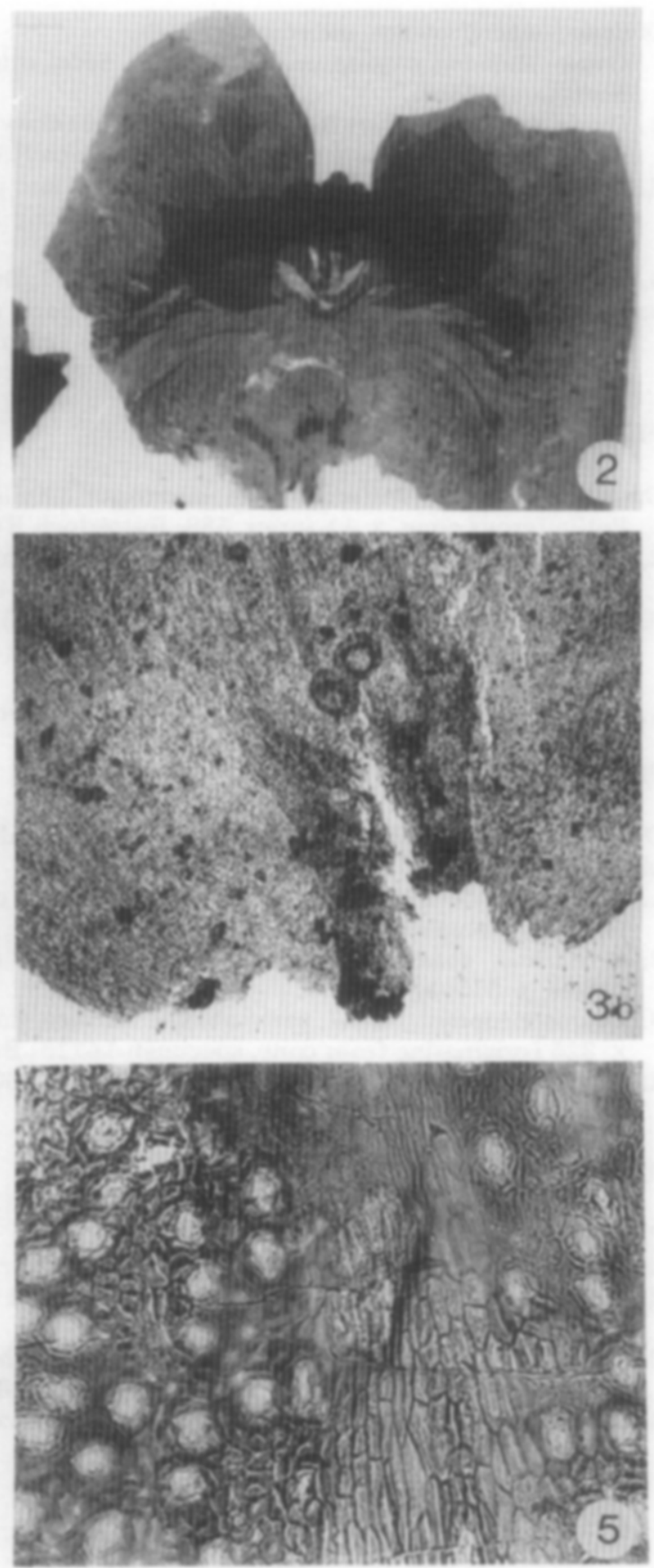

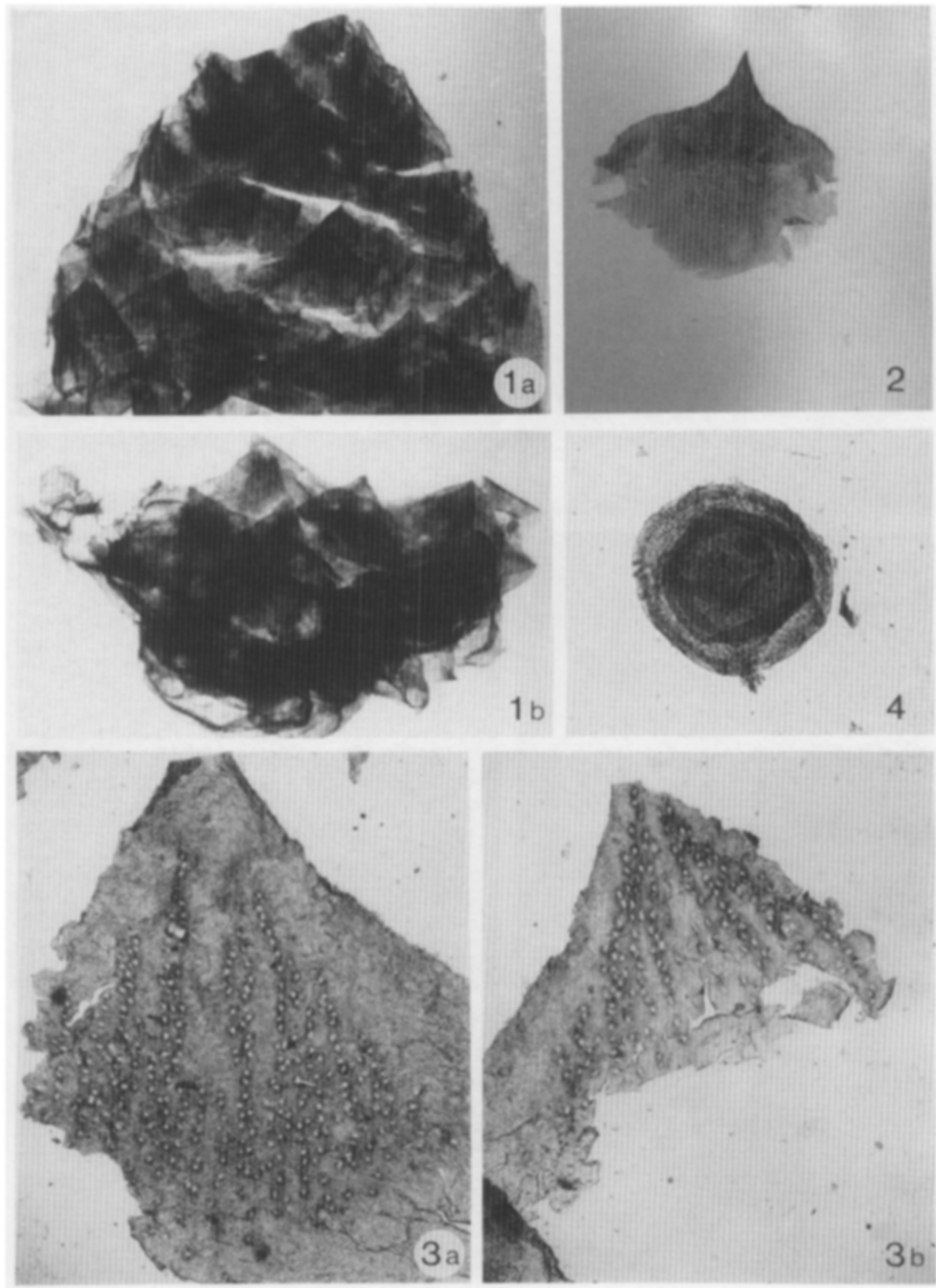

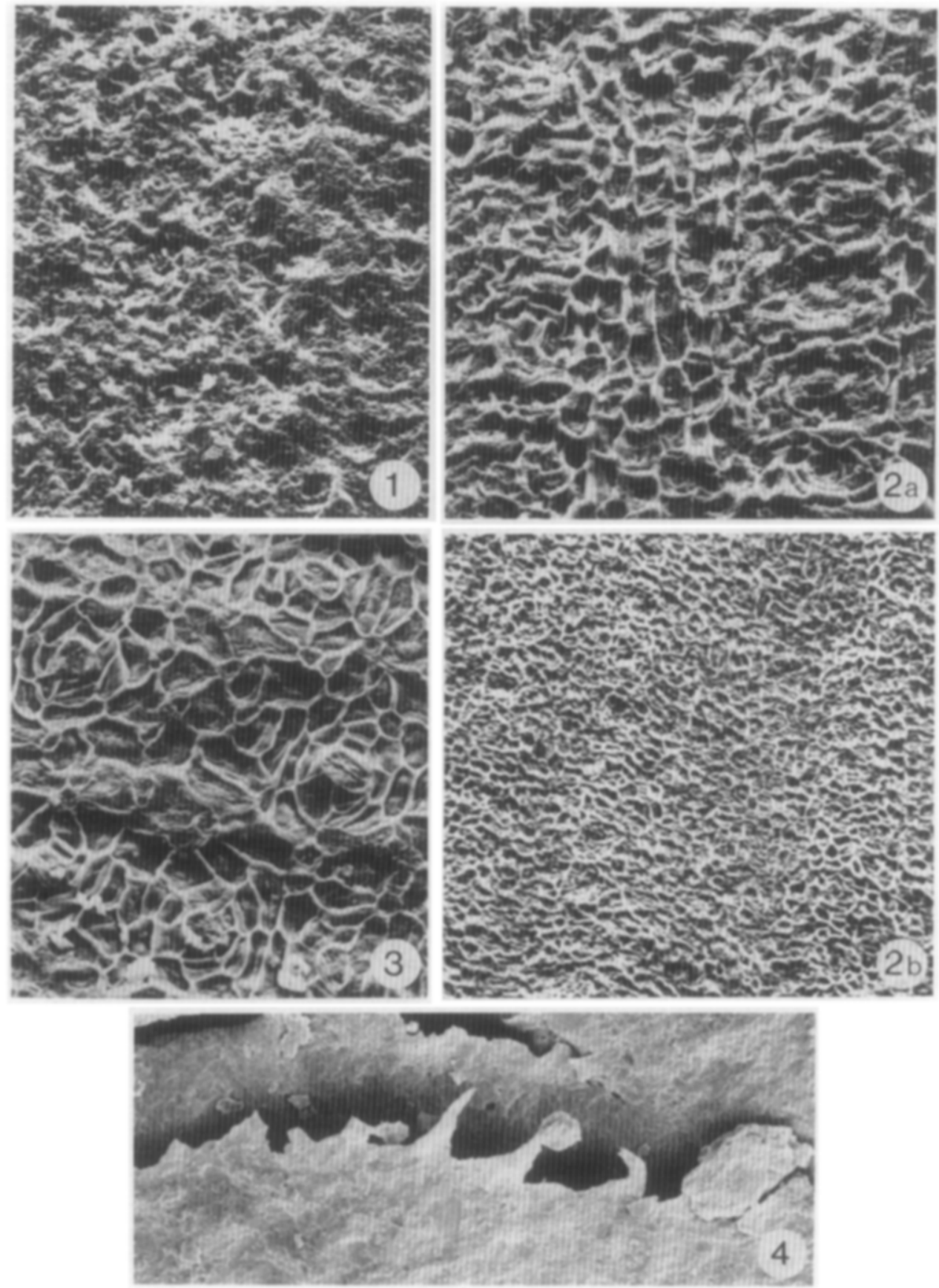

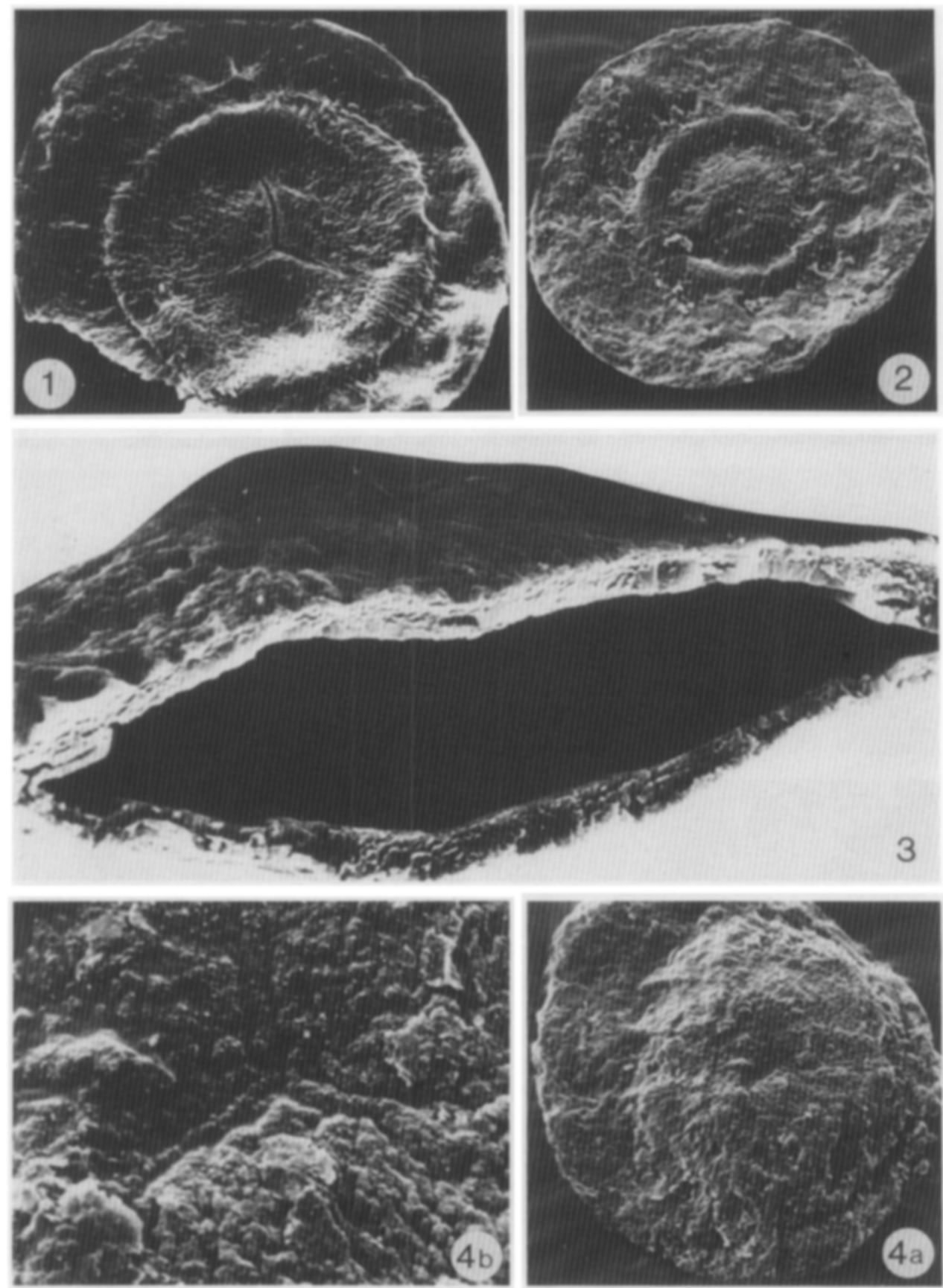


\section{PLATE XXXIII}
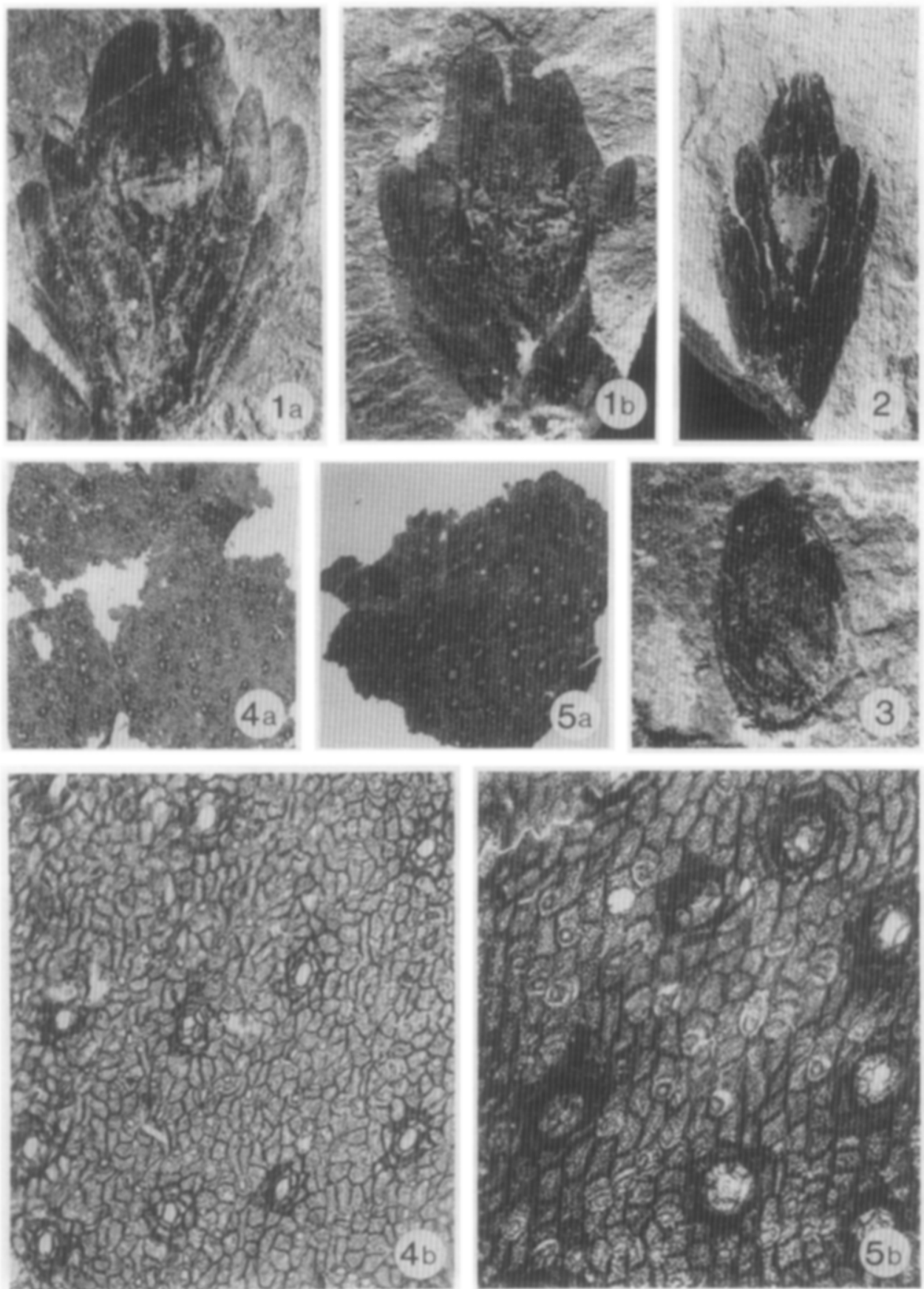
PLATE XXXIII (p. 162)

Walchia sp.: ovuliferous dwarf-shoots, seed; Culmitzschia florinii: epidermal structure

1. Walchia sp., dwarf-shoot, $\times 4.35$ (specimen 8411 AB; Sobernheim): a, contour of ovule visible on the bilobated megasporophyll; $b$, counter-part.

2. Walchia sp., dwarf-shoot, $x 3.6$ (specimen collected by Mr. K. Baum; Sobernheim).

3. Seed, probably belonging to Walchia, $\times 4.35$ (specimen $8272 \mathrm{~B}$; Sobernheim).

4. Culmitzschia florinii, epidermal structure (Zechstein, Poland): $a, \times 26 ; b$, detail, $\times$ 130.

5. Culmitzschia florinii, epidermal structure (Zechstein, Poland): a, $\times 26$; b, detail, $\times$ 130.

\section{REFERENCES}

Andrews, H.N., 1970. Index of generic names of fossil plants, 1820-1965. U.S. Geol. Surv. Bull., 1300: 354 pp.

Assereto, R., Bosselini, A., Fantani Sestini, N. and Sweet, W.C., 1973. In: A. Logan and L.V. Hills (Editors), The Permian and Triassic Systems and Their Mutual Boundary. Can. Soc. Pet. Geol., Mem., 2: 176-199.

Barbieri, G., De Vecchi, G., De Zancha, V., Di Lallo, E., Frizzo, P., Mietto, P. and Sedea, R., 1980. Note illustrative della carta geologica dell'area di Recoaro alla scale 1:20.000. Mem. Ist. Geol. Mineral. Univ. Padova, 34: 23-32.

Bharadwaj, D.C., 1964. The organization in pollengrains of some early conifers. Palaeobotanist, 12(1): 18-27.

Bhardwaj, D.C., 1954. Einige neue Sporengattungen der Saarkarbons. Neues Jarhb. Geol. Paläontol., Monatsh., 11: 512-525.

Bittner, A., 1879. Trịas von Recoaro. Verh. K.K. Geol. Reichsanst., 3: 71-78.

Bittner, A., 1881. Über die Triasbildungen von Recoaro. Verh. K.K. Geol. Reichsanst., $14: 273-275$.

Bittner, A., 1883. Bericht über die geologischen Aufnahmen im Triasgebiet von Recoaro. Jahrb. K.K. Geol. Reichsanst., 33(4): 563-634.

Bosellini, A. and Dal Cin, R., 1968. Sedimentologia delle Arenarie di Val Gardena. Sezione di S. Martino in Badia (Bolzano). Boll. Soc. Geol. Ital., 87: 401-423.

Brongniart, A., 1828. Histoire des Végétaux Fossiles. Du four et d'Ocagne, Paris, 488 pp.

Brongniart, A., 1837-1838. Histoire des Végétaux Fossiles, 2. Crochard, Paris, 72 pp.

Brongniart, A., 1849. Végétaux Fossiles. In: C. d'Orbigny (Editor), Dictionnaire Universel d'Histoire Naturelle, 13. Renard, Martinet \& Cie, Paris, pp. 52-173.

Buggish, W., 1978. Die Grödener Schichten (Perm, Südalpen). Sedimentologische und geochemische Untersuchungen zur Unterscheidung mariner und kontinentaler Sedimente. Geol. Rundsch., 67(1): 149-180.

Celakovský, L., 1890. Die Gymnospermen. Eine morphologisch-phylogenetische Studie. Abh. Böhm. Ges. Wiss. (Math.-Nat.), 7(4): 1-148.

Celakovský, L., 1900. Neue Beiträge zum Verstandnis der Fruchtschuppe der Coniferen. Jahrb. Wiss. Bot., 35: 407-448.

Chamberlain, C.J., 1935. Gymnosperms, Structure and Evolution. University of Chicago Press, Chicago, Ill., 484 pp.

Charrier, G., 1964. Legni fossili del Permiano medio delle Cuecenes presso Ortisei (Val Gardena). Mem. Geopalaeontol. Univ. Ferrara, 1(1): 19-47.

De Boer, J., 1963. The geology of the Vicentinian Alps (NE Italy). Geol. Ultraiectina, $11: 175 \mathrm{pp}$.

De Zigno, A., 1862. Sulle piante fossili del Trias di Recoaro. Mem. R. Ist. Veneto, 11: 1-31.

Dijkstra, S.J., 1975. Ginkgophyta, Coniferae. Fossilium Catalogus, II Plantae, 87: 937-1094.

Doyle, J., 1926. Notes on the staminate cone of Larix leptolepis. Proc. Roy. Irish Acad., 37(B): 154-169. 
Florin, R., 1927. Preliminary descriptions of some Palaeozoic genera of Coniferae. Ark. Bot., 21A(13): 1-7.

Florin, R., 1934. Note on the nomenclature of Palaeozoic Conifers. Svensk. Bot. Tidskr., 28: 468-469.

Florin, R., 1938. Die Koniferen des Oberkarbons und des unteren Perms. I. Palaeontographica, B 85: 2-63.

Florin, R., 1939a. Die Koniferen des Oberkarbons und des unteren Perms. II. Palaeontographica, B 85: 64-123.

Florin, R., 1939b. Die Koniferen des Oberkarbons und des unteren Perms. III. Palaeontographica, B 85: 124-175.

Florin, R., 1939c. Die koniferen des Oberkarbons und des unteren Perms. IV. Palaeontographica, B 85: 176-243.

Florin, R., 1940. Die Koniferen des Oberkarbons und des unteren Perms. V. Palaeontographica, B $85: 244-365$.

Florin, R., 1944a. Die Koniferen des Oberkarbons und des unteren Perms. VI. Palaeontographica, B 85: 366-458.

Florin, R., 1944b. Die Koniferen des Oberkarbons und des unteren Perms. VII. Palaeontographica, B 85: 459-654.

Florin, R., 1945. Die Koniferen des Oberkarbons und des unteren Perms. VIII. Palaeontographica, B 85:655-729.

Florin, R., 1951. Evolution in cordaites and conifers. Acta Hort. Berg., 15: 285-388.

Florin, R., 1954. The female reproductive organs of conifers and taxads. Biol. Rev., 29: $367-389$.

Florin, R., 1964. Über Ortiseia leonardii n. gen. et sp., eine Konifere aus den Grödener Schichten in Alto Adige (Südtirol). Mem. Geopalaeontol, Univ. Ferrara, 1(1): 3-11.

Göppert, H.R., 1836. Die fossilen Farrnkräuter. Eduard Weber, Breslau, $472 \mathrm{pp}$.

Göppert, H.R., 1850. Monographie der fossilen Coniferen. Arnz, Leiden, $286 \mathrm{pp}$.

Göppert, H.R., 1864-1865. Die fossile Flora der Permischen Formation. Palaeontographica, 12: 1-316.

Grauvogel-Stamm, L., 1978. La flore du Grès à Voltzia (Buntsandstein Supérieur) des Vosges du Nord (France): Morphologie, anatomie, interprétations phylogenétique et paléogéographique. Sci. Géol., Mém., 50: 225 pp.

Gümbel, C.W., 1879. Geognostische Mittheilungen aus den Alpen. V. Die Pflanzenreste führenden Sandsteinschichten von Recoaro. Sitzungsber. Bayer. Akad. Wiss., Math.Phys., 9(2): 33-85.

Hagerup, O., 1933. Zur Organogenie und Phylogenie der Koniferen-Zapfen. Biol. Medd., 10(7): 1-82.

Harris, T.M., 1976. The Mesozoic gymnosperms. Rev. Palaeobot. Palynol., 21 : 119-135.

Heer, O., 1876. Über permischen Pflanzen von Fünfkirchen (in Ungarn). Mitth. Jahrb. K. Ung. Geol. Anst., 5: 1-18.

Jung, W., 1977. Oberpermische Koniferereste aus dem Sandsteinsockel des Schlernmassivs (südtiroler Dolomiten). Mitt. Bayer. Staatssamml. Paläontol. Hist. Geol., 17: $235-247$.

Klaus, W., 1963. Sporen aus dem südalpinen Perm (Vergleichsstudie für die Gliederung nordalpiner Salzserien). Jahrb. Geol. Bundesanst. (Austria), 106: 229-363.

Kräusel, R., 1939. Besprechungen. Neues Jahrb. Mineral., Geol., Paläontol., Referate III, 1939: 535-537.

Lam, H.J., 1954. Again: the new morphology - elucidated by the most likely phylogeny of the female coniferous cone. Svensk Bot. Tidskr., 48(2): 347-360.

Lee, H.H., Chow, T.Y. and Deng, L.H., 1974. Chinese Fossils. Chinese Plant Fossils I: Chinese Palaeozoic Plants. Comp. Comm. Bot. Inst. Nanking Geol. Paleontol. Inst. Acad. Sinica, Sci. Press, 277 pp. (in Chinese).

Leonardi, P., 1951. Contributi alla conoscenza della flora delle arenarie di Val Gardena (Permiano medio-inf.) dell' Alto-Adige: la nuova flora di Redagno e una felce di Egna. Mem. Ist. Geol. Univ, Padova, 16: 3-15.

Leonardi, P., 1967. Le Dolomiti. Geologia dei Monti tra Isarco e Pieve, Vol. I, II. Natl. Res. Council, Rome, 1019 pp. 
Massalongo, A., 1863. Constituzione geologica di Recoaro e dell' suoi dintorni. Atti $R$. Ist. Veneto, 9 : 95-104.

Meyen, S.V., 1968. Some general questions concerning the systematics and evolution of conifers in connection with the open ovule of Buriadia. Paleontol. $\mathrm{Zh}$., 4: 28-31 (in Russian).

Meyen, S.V., 1983. Two weeks in the Museum für Naturkunde (Berlin, DDR). I.O.P. Newsletter, $20: 7$.

Millay, M.A. and Taylor, T.N., 1974. Morphological studies of Palaeozoic saccate pollen. Palaeontographica, B 147 (4-6): 75-99.

Miller, C.N. and Brown, J.T., 1973. A new voltzialean cone bearing seeds with embryos from the Permian of Texas. Am. J. Bot., 60(6): 561-569.

Miller, S.A., 1889. North American Geology and Palaeontology for the use of Amateurs, Students and Scientists. North American Palaeozoic Fossils. Vegetable Kingdom. Cincinnati, Ohio, pp.101-149.

Miquel, F.A.G., 1851. De quibusdam plantis fossilibus. Tijdschr. Wis.- Natuurk. Wet., 4: 265-269.

Moore, R.C., 1933. Historical Geology. McGraw-Hill, New York, NY.

Nathorst, A.G., 1897. Zur fossilen Flora der Polarländer. 1. Theil. 2. Lieferung: Zur mesozoischen Flora Spitzbergens. K. Svensk Vet. Akad. Handl., 30(1): 1-77.

Ogilvie-Gordon, M.M., 1927. Das Grödner-, Fassa- und Enneberggebiet in der Südtiroler Dolomiten, I-III. Abh. Geol. Bundesanst., 24(1): 376 pp.

Pant, D.D., 1982. The Lower Gondwana gymnosperms and their relationships. Rev. Palaeobot. Palynol, $37: 55-70$.

Pant, D.D. and Nautiyal, D.D., 1967. On the structure of Buriadia heterophylla (Feistmantel) Seward et Sahni and its fructifications. Philos. Trans. R. Soc. Lond., B 774: $27-48$.

Pilger, R., 1926. Gymnospermae 6: Klasse Coniferae. In: A. Engler and K. Prantl (Editors), Die natürlichen Pflanzenfamilien, 13. Engelmann, Leipzig, pp.121-403.

Potonié, R. and Klaus, W., 1954. Einige Sporengattungen des alpinen Salzgebirges. Geol. Jahrb., 68: 517-544.

Potonié, R. and Schweitzer, H.J., 1960. Der Pollen von Ullmannia frumentaria. Paläontol. Z., 34: 27-39.

Remy, W. and Remy, R., 1977. Die Floren des Erdaltertums. Verlag Glückauf, Essen, $468 \mathrm{pp}$.

Remy, W. and Remy, R., 1978. Die Flora des Perms im Trompia-Tal und die Grenze Saxon/Thüring in den Alpen. Argum. Palaeobot., $5: 57-90$.

Renault, B., 1885. Cours de botanique fossile, IV. Masson, Paris, 232 pp.

Rostovtsev, K.O. and Azaryan, N.R., 1973. The Permian-Triassic boundary in Transcaucasia. In: A. Logan and L.V. Hills (Editors), The Permian and Triassic Systems and Their Mutual Boundary. Can. Soc. Pet. Geol., Mem., 2: 89-99.

Rothwell, G.W., 1982. New interpretations of the earliest conifers. Rev. Palaeobot. Palynol., 37: 7-28.

Sahni, B. and Rao, A.R., 1933. On some Jurassic plants from the Rajmahal Hills. Proc. Asiatic Soc. Bengal, 27(2): 183-208.

Schimper, W.P., 1870-1872. Traité de Paléontologie végétale ou la flore du monde primitif dans ses rapports avec les formations géologiques et la flore du monde actuel, 2. Baillière et fils, Paris, $966 \mathrm{pp}$.

Schweitzer, H.J., 1962. Die Makroflora des niederrheinischen Zechsteins. Fortschr. Geol. Rheinl. West., 6:331-377.

Schweitzer, H.J., 1963. Der weibliche Zapfen von Pseudovoltzia liebeana und seine bedeutung für die Phylogenie der Koniferen. Palaeontographica, B 113: 1-29.

Schweitzer, H.J., 1968. Die Flora des oberen Perms in Mitteleuropa. Naturwiss. Rundsch., 21(3): 93-102.

Schuster, A., 1933. Oberrotliegendes und Zechstein in Sachsen. Abh. Sächs. Geol. Landesamt, 13: 1-97. 
Stenzel, G., 1876. Beobachtungen an durchwachsenen Fichtenzapfen. Ein Beitrag zur Morphologie der Nadelhölzer. Nova Acta Leop.-Carol. Dtsch. Akad. Naturforsch., 38(3): $289-350$.

Sternberg, K., 1825. Versuch einer geognostisch-botanischen Darstellung der Vorwelt. 1(4). Brenck, Regensburg, 42 pp.

Stockey, R.A., 1982. The Araucariaceae: an evolutionary perspective. Rev. Palaeobot. Palynol., 37: 133-154.

Tornquist, A., 1901. Das Vicentinischen Triasgebirge. Eine geologische Monographie. K. Preuss. Akad. Wiss., Stuttgart, 195 pp.

Townrow, J.A., 1967. On Voltziopsis a southern conifer of Lower Triassic age. Pap. Proc. R. Soc. Tasmania, 101: 173-188.

Ullrich, H., 1964. Zur stratigraphie und Paläontologie der marin-beeinflussten Randfazies des Zechsteinbeckens in Ostthüringen und Sachsen. Freib. Forschungsh., C 169: $1-163$.

Van de Laar, J.G.M., 1980. Aspects of Upper Permian and Lower Triassic Palynology: Palynological Investigations in the Upper Permian and Lower Triassic of the Vicentinian Alps and Western Dolomites (NE-Italy). Unpublished report, Lab. Palaeobot. Palynol., State University, Utrecht, 118 pp.

Van Tieghem, P., 1869. Anatomie comparée de la fleur femelle et du fruit des Cycadées, des Conifères et des Gnétacées. Ann. Sci. Nat. Bot., 5(10): 269-304.

Visscher, H., 1971. The Permian and Triassic of the Kingscourt outlier, Ireland - a palynological investigation related to regional stratigraphical problems in the Permian and Triassic of western Europe. Geol. Surv. Irel., Spec. Pap., 1: 114 pp.

Visscher, H., 1973. The Upper Permian of western Europe - a palynological approach to chronostratigraphy. In: A. Logan and L.V. Hills (Editors), The Permian and Triassic Systems and Their Mutual Boundary. Can. Soc. Pet. Geol., Mem., 2: 200-219.

Visscher, H., 1980. Aspects of a palynological characterization of Late Permian and Early Triassic "standard" units of chronostratigraphical classification in Europe. In: Proc. 4th Int. Palynol. Conf., Lucknow, 1976-1977, 2: 236-244.

Visscher, H., Huddleston Slater-Offerhaus, M.G. and Wong, T.E., 1974. Palynological assemblages from "Saxonian" deposits of the Saar-Nahe Basin (Germany) and the Dôme de Barrot (France) - an approach to chronostratigraphy. Rev. Palaeobot. Palynol., 17: 39-56.

Von Mojsisovics, E.M., 1876. Die Triasbildungen bei Recoaro im Vicentinischen. Verh. K.K. Geol. Reichsanst., 3: 238-241.

Von Schlotheim, E.F., 1820. Die Petrenfactenkunde auf ihrem jetzigen Standpunkte. Becker, Gotha, 437 pp.

Von Wettstein, R., 1935. Handbuch der systematischen Botanik. Wettstein, 4th ed., Leipzig, Vienna, 1149 pp.

Weigelt, J., 1928. Die Pflanzenreste des mitteldeutschen Kupferschiefers und ihre Einschaltung ins Sediment. Eine palökologische Studie. Fortsehr. Geol. Paläontol., 6(19): 395-592.

Wilde, M.H., 1944. A new interpretation of coniferous cones. I. Podocarpaceae (Podocarpus). Ann. Bot., N.S., 8(29): 1-41.

Wilde, M.H. and Eames, A.J., 1955. The ovule and "seed" of Araucaria bidwillii with discussion of the taxonomy of the genus. III. Anatomy of multi-ovulate cone scales. Ann. Bot., N.S., 19: 343-349.

Zeiller, R., 1892. Bassin houiller et permien de Brive. II. Flore fossile - Études des Gîtes Mineraux de la France. Minist. Trav. Publ., Paris, 132 pp.

Zimmermann, W., 1941. Besprechungen. Z. Bot., 36(6-8): 393-395.

Zimmermann, W., 1959. Die Phylogenie der Pflanzen. Fischer, 2nd ed., Stuttgart, 777 pp. 